\title{
Process Based Analysis Of Fluvial Stratigraphic Record: Middle Pennsylvanian Allegheny Formation, North-Central WV
}

\author{
Oluwasegun 0. Abatan \\ olabatan@mix.wvu.edu
}

Follow this and additional works at: https://researchrepository.wvu.edu/etd

Part of the Geology Commons, Multivariate Analysis Commons, Numerical Analysis and Scientific Computing Commons, Sedimentology Commons, Statistical Methodology Commons, and the Stratigraphy Commons

\section{Recommended Citation}

Abatan, Oluwasegun O., "Process Based Analysis Of Fluvial Stratigraphic Record: Middle Pennsylvanian Allegheny Formation, North-Central WV" (2020). Graduate Theses, Dissertations, and Problem Reports. 7645.

https://researchrepository.wvu.edu/etd/7645

This Dissertation is protected by copyright and/or related rights. It has been brought to you by the The Research Repository @ WVU with permission from the rights-holder(s). You are free to use this Dissertation in any way that is permitted by the copyright and related rights legislation that applies to your use. For other uses you must obtain permission from the rights-holder(s) directly, unless additional rights are indicated by a Creative Commons license in the record and/ or on the work itself. This Dissertation has been accepted for inclusion in WVU Graduate Theses, Dissertations, and Problem Reports collection by an authorized administrator of The Research Repository @ WVU. For more information, please contact researchrepository@mail.wvu.edu. 


\title{
PROCESS BASED ANALYSIS OF FLUVIAL STRATIGRAPHIC RECORD: MIDDLE PENNSYLVANIAN ALLEGHENY FORMATION, NORTH-CENTRAL WV
}

\author{
Oluwasegun Abatan
}

Dissertation submitted to the Eberly College of Science at West Virginia University in partial fulfillment of the requirements for the degree of Doctor of Philosophy in Geology

\author{
Amy Weislogel, Ph.D., Chair \\ Bascombe Blake, Ph.D. \\ Jaime Toro, Ph.D. \\ Shikha Sharma Ph.D. \\ Steve Kite Ph.D., \\ Department of Geology
}

Morgantown, West Virginia 2020

Keywords: Sedimentology, Stratigraphy, Fluvial, Facies, Petrography, Allegheny Formation, Machine Learning, Numerical Modelling

Copyright 2020 Oluwasegun Abatan 


\section{ABSTRACT \\ PROCESS BASED ANALYSIS OF FLUVIAL STRATIGRAPHIC RECORD: MIDDLE PENNSYLVANIAN ALLEGHENY FORMATION, NORTH-CENTRAL WV}

\section{Oluwasegun Abatan}

Fluvial deposits represent some of the best hydrocarbon reservoirs, but the quality of fluvial reservoirs varies depending on the reservoir architecture, which is controlled by allogenic and autogenic processes. Allogenic controls, including paleoclimate, tectonics, and glacioeustasy, have long been debated as dominant controls in the deposition of fluvial strata. However, recent research has questioned the validity of this cyclicity and may indicate major influence from autogenic controls. To further investigate allogenic controls on stratal order, I analyzed the facies architecture, geomorphology, paleohydrology, and the stratigraphic framework of the Middle Pennsylvanian Allegheny Formation (MPAF), a fluvial depositional system in the Appalachian basin, to test for the dominant allogenic and/ or autogenic controls during deposition.

A sedimentological process based approach has been used to analyze controls on the depositional reservoir quality of fluvial sandstone units. In this research, I utilized facies architectural analysis to identify four depositional styles for channel deposits of the MPAF. The depositional facies were used to identify paleoclimatic controls on fluvial sedimentary fill. I introduced a new, efficient numerical model to aid in channel geometry and paleohydrological modeling of the MPAF channels. The new numerical modeling method increased the accuracy of estimated channel geomorphology and hydrologic processes. I proposed a sequence stratigraphic framework, which utilized surfaces of floodplain paleosols and erosional channel bases, to correlate fluvial depositional packages across the Appalachian basin. The integration of facies architectural analysis and sequence stratigraphic allowed the differentiation of accommodation and controls on accommodation within vertically stacked deposits of the fluvial depositional system. 


\section{Acknowledgment}

I would like to express my gratitude to my adviser Dr. Amy Weislogel first for allowing me to conduct my Ph.D. at WVU. Her guidance and words of encouragement saw me through tough times. I have learned a lot from her, both in academics and life. Working with you was fun and relaxing which helped keep my focus. Thanks for all your support.

I would like to thank my committee, Dr. Amy Weislogel, Dr. Bascombe Blake, Dr. Steve Kite, Dr. Jaime Toro and Dr. Shikha Sharma for their guidance and nudge in the right direction without which I will not have completed my Ph.D. research on time. I would especially like to thank Dr. Mitch Blake for his help with data, professional advice and time spent with me on Appalachian outcrops. I appreciate all the time you took to go out to the field with me. I don't think I would have been able to complete this program without your contribution. For that I am grateful.

I would also like to thank the geology department and my colleague that has made my stay in the WVU Geology and Geography department wonderful. I would especially like to thank Sofia Andeskie and Emily Bausher for all the countless favors. I know I still owe you guys.

Thanks to the geoscience team at EQT for the opportunity to intern for two summers. I would like to thank my mentors Craig A. Eckert, Christopher Chase and Scott McCallum for their patience and support during and after my internship. I would also like to thank Joe Andrie, Travis Warner and Randy Blood for their help during the internship.

This research was funded by the American Association of Petroleum Geologist (AAPG), Eberly College of Art and Science and the Pittsburgh Association of Petroleum Geologist (PAPG).

Most importantly I will like to thank my family for their continuous encouragement and support throughout my Ph.D. program.

Dedicated to my daughter, Tara, and wife, Lola. Thanks, for everything. I love you guys so much.

Sincerely,

Segun Abatan 


\section{TABLE OF CONTENTS}

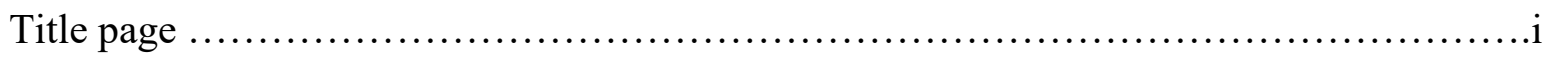

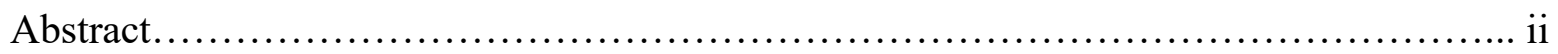

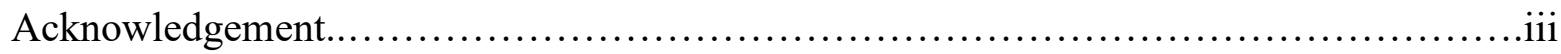

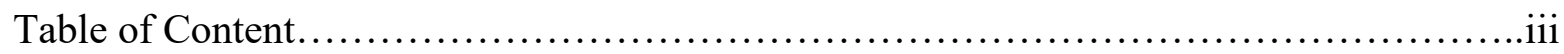

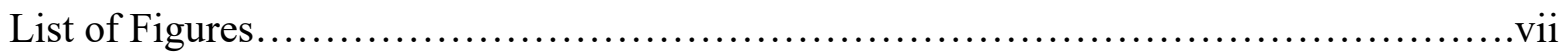

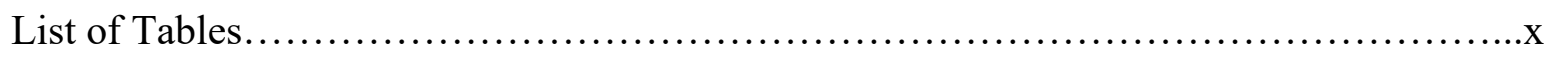

Chapter 1 - Facies Analysis and Depositional Environments of the Lower Allegheny Formation, Appalachian Basin: Implications for Middle Pennsylvanian Paleoclimate

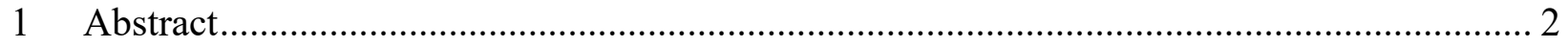

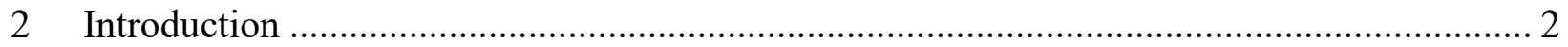

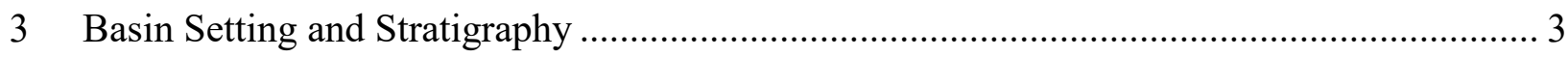

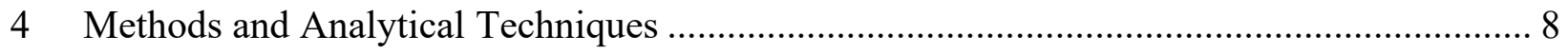

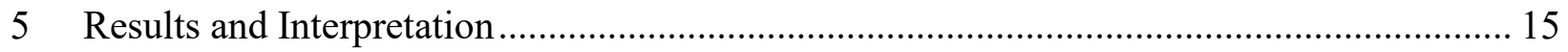

5.1 Lithofacies Description and Hydrologic Interpretation .................................................. 15

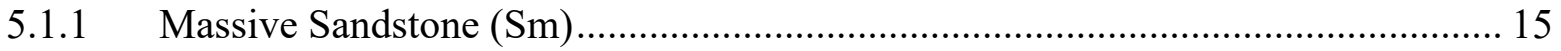

5.1.2 Horizontal Planar-stratified Sandstone (Sh) .................................................... 15

5.1.3 Low-angle Cross-stratified Sandstone (Sl) ………………………………….... 15

5.1.4 Planar Cross-stratified Sandstone (Sp) ………................................................... 16

5.1.5 Trough Cross-stratified Sandstone (St)............................................................ 16

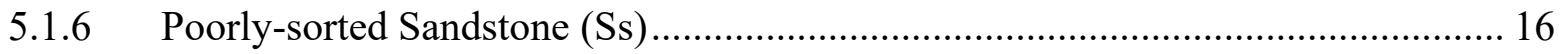

5.1.7 Ripple Laminated Sandstone (Sr) .............................................................. 17

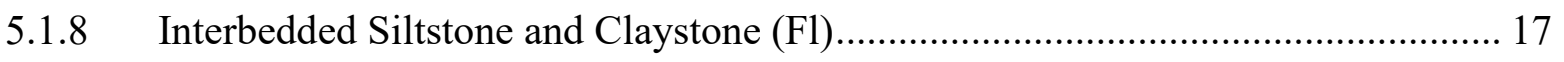

5.1.9 Massive Siltstone or Claystone (Fm) ............................................................. 17

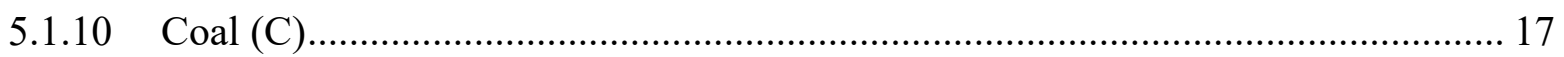

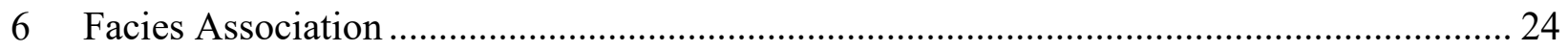

6.1 Fluvial Channel Deposits: Facies Association A ............................................................ 24

6.1.1 Facies Association A1: Low-sinuosity fluvial channel deposits ............................ 24

6.1.2 Facies Association A2: Braided fluvial deposits .................................................. 26 
6.1.3 Facies Association A3: Upper flow regime fluvial channel deposits .................. 29

6.1.4 Facies Association A4: Sinuous fluvial channel deposits.................................. 31

6.2 Non-fluvial Channel Deposits: Facies Association B............................................... 34

6.2.1 Facies Association B1: Poorly-drained floodplain deposits ................................ 34

6.2.2 Facies Association B2: Well-drained flood plain deposits ................................. 36

6.2.3 Facies Association B3: Lacustrine deposits.................................................... 38

6.2.4 Facies Association B4: Swamp/peat mire deposits ......................................... 39

7 Sediment Transport, Sandstone Composition and Provenance ....................................... 41

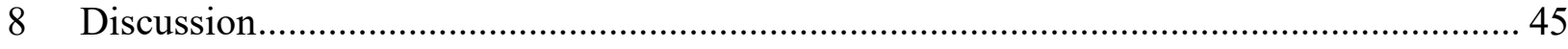

8.1 Evolution of the Lower Middle Pennsylvanian Allegheny Formation Depositional

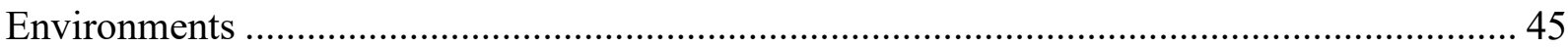

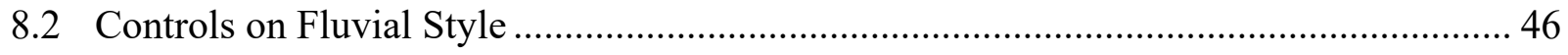

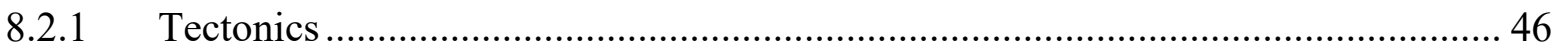

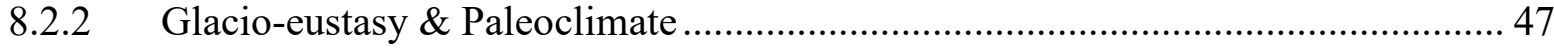

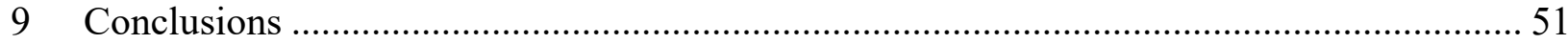

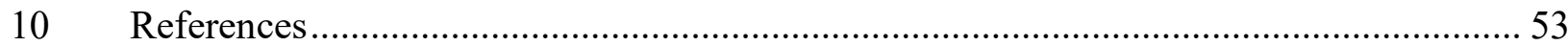

Chapter 2 - Paleohydrology and Machine-assisted Estimation of Paleogeomorphology of Fluvial Channels of the Lower Middle Pennsylvanian Allegheny Formation, Birch River, WV

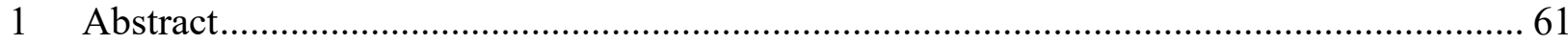

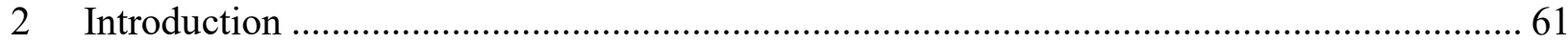

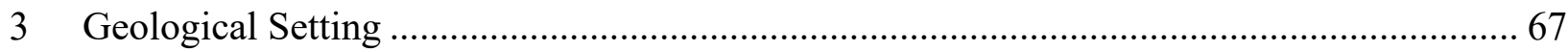

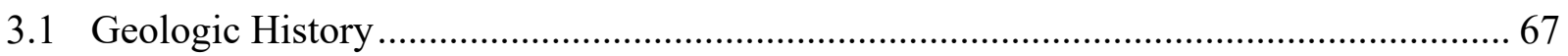

3.2 MPAF Channel Belts, Birch River, WV ................................................................. 68

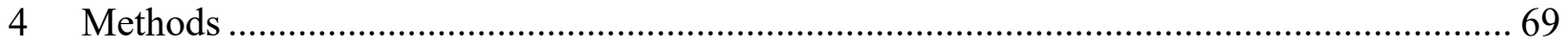

4.1 Facies Architecture of the MPAF Channel Belts......................................................... 69

4.2 Paleochannel Geometry Measurements and Estimation................................................ 69

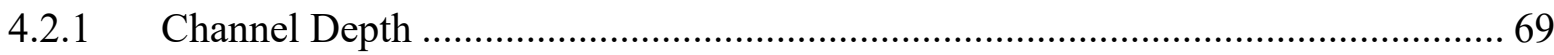

4.2.2 Machine-Assisted Estimation of Channel Belt ............................................. 70

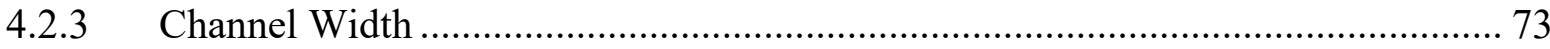

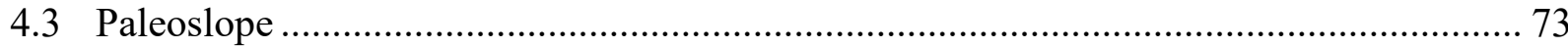

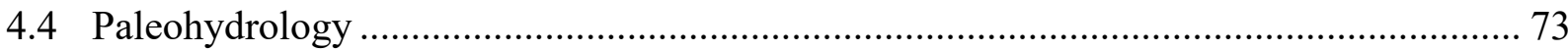




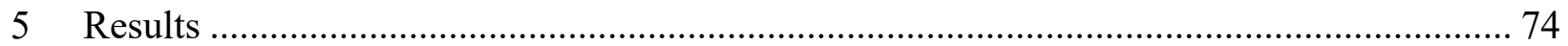

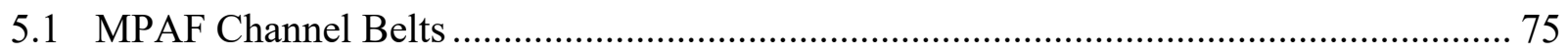

5.1.1 Channel Belt 1: Low sinuosity fluvial system .................................................. 75

5.1.2 Channel Belt 2: Braided fluvial system .......................................................... 75

5.1.3 Channel Belt 3: High-velocity channel ..................................................................... 76

5.1.4 Channel Belt 4: Sinuous meandering channel .................................................. 76

5.2 Machine-assisted Approach to Dune Height Estimation from Cross-bed Height ............. 77

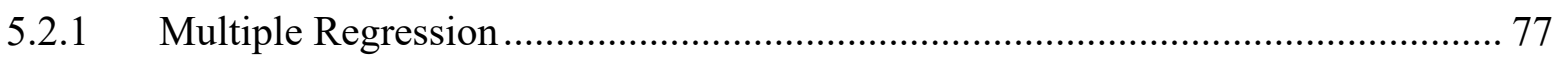

5.2.2 Support Vector Regression (SVR) vs. Polynomial Regression ................................ 77

5.3 Paleochannel Depth Estimates ........................................................................................ 78

5.4 Paleochannel Width Estimates................................................................................... 83

5.5 Paleoslope Estimation........................................................................................... 84

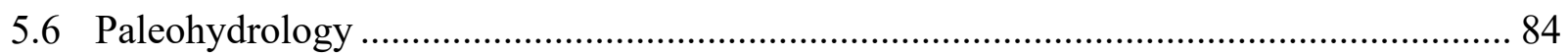

5.7 Errors and Uncertainties Associated with Numerical Analysis ...................................... 86

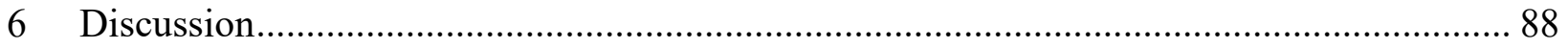

6.1 Machine-assisted Paleohydrological Analysis................................................................ 88

6.1.1 Advantages of SVR over Polynomial Regression ................................................. 88

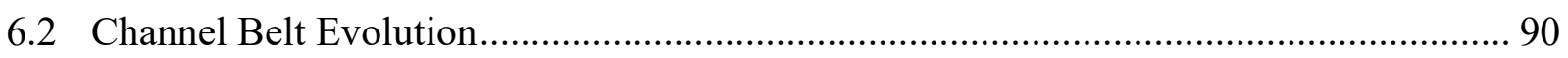

6.3 Possible Controls on Fluvial Channel Geometry and Paleohydrology ………………..... 92

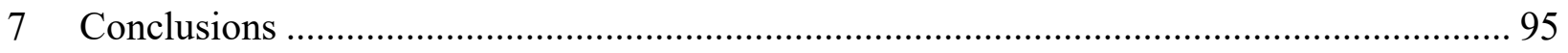

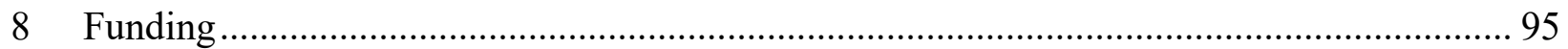

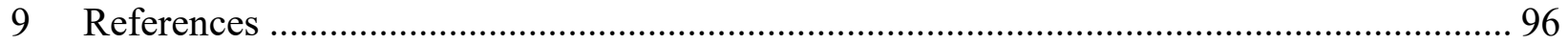

Chapter 3 - Stratigraphy framework for the Sequence Stratigraphic Analysis of Fluvial Depositional Systems: Example from the Middle Pennsylvanian Allegheny Formation (MPAF) South-Central, West Virginia

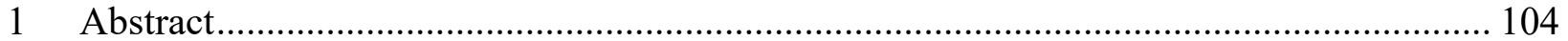

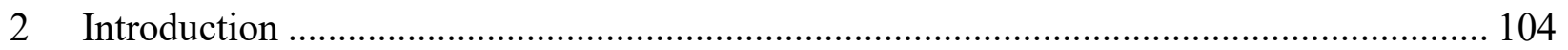

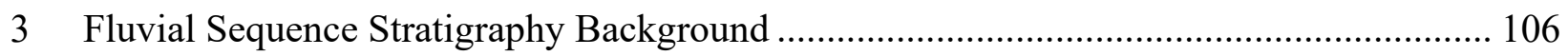

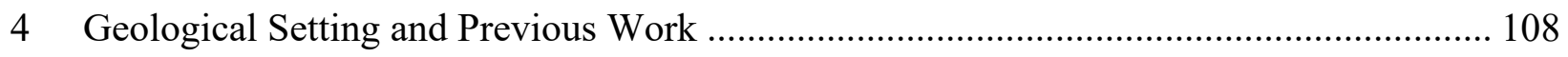

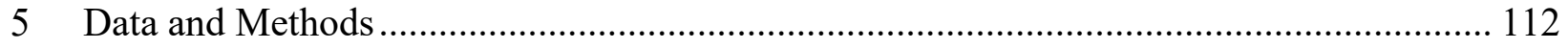

$5.1 \quad$ Stratigraphic Analysis ...................................................................................... 113 
5.1.1 Accommodation Succession ..................................................................... 113

5.1.2 Bounding Surfaces .................................................................................. 114

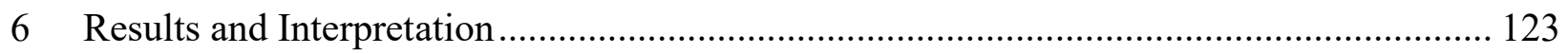

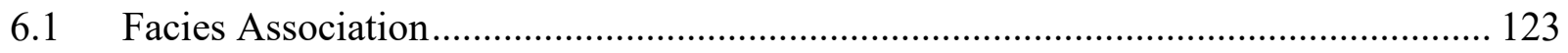

6.1.1 Facies Association 1 - Channel Deposits ...................................................... 123

6.1.2 Facies Association 2 - Floodplain Deposits (Including crevasse splay, paleosol and

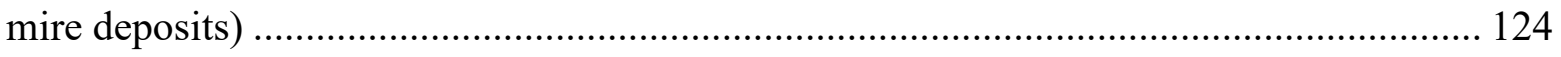

6.1.3 Facies Association 3 - Floodplain Delta and Lake Deposit ............................. 124

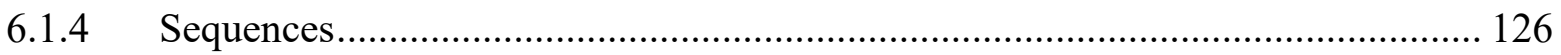

6.2 Controlling Mechanisms of Base-level Changes and Accommodation................. Error! Bookmark not defined.

7 Conclusion ..............................................................................error! Bookmark not defined.

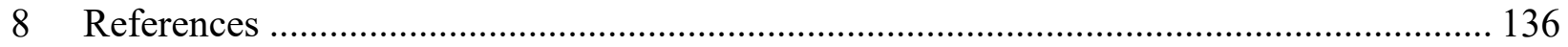




\section{LIST OF FIGURES}

Figure 1-1: Simplified chronostratigraphic column. Study interval includes No. 5 Block, Upper No.5 Block, and Lower Kittanning coal beds and associated clastic deposits (red square). Modified from Blake et al. (2002), Cecil et al. (2004), Montañez et al. (2016) and Abatan and Weislogel (2020).

Figure 1-2: Location of study area. Map of West Virginia with geologic map of MPAF outcrop and study area.

Figure 1-3: Section of the lower Middle Pennsylvanian Allegheny Formation used for this study at Powel Mountain, Birch River West Virginia. See $\sim 2 \mathrm{~m}$ tall person for scale. (Red Circles).

Figure 1-4: Lithofacies of lower Middle Pennsylvanian Allegheny Formation. A) Massive sandstone (Sm facies). Diameter of circular level is $10 \mathrm{~cm}$ for scale B) Planar-stratified sandstone (Sh facies). Long side of triangular ruler is $11 \mathrm{~cm}$ for scale. C) Low angle crossstratified sandstone (S1 facies). Pencil length is $15 \mathrm{~cm}$ for scale. D) Planar cross-stratified sandstone (Sp facies). Pencil length is $15 \mathrm{~cm}$ for scale. E) Trough cross-stratified sandstone (St facies). Long side of triangular ruler is $11 \mathrm{~cm}$ for scale. F) Poorly sorted conglomerate and sandstone (Ss facies). Long side of triangular ruler is $11 \mathrm{~cm}$ for scale. G) Ripple bedded sandstone ( $\mathrm{Sr}$ facies). Long side of triangular ruler is $11 \mathrm{~cm}$ for scale. H) Interlaminated siltstone and mudrock (Fl facies). Long side of triangular ruler is $11 \mathrm{~cm}$ for scale. I) Massive mudrock (Facies Fm). Pencil length is $15 \mathrm{~cm}$ for scale. J) Coal bed (C facies). Field note length is $25 \mathrm{~cm}$ for scale.

Figure 1-5: Composite stratigraphic column of the lower Middle Pennsylvanian Allegheny Formation study interval at Birch River, West Virginia with interpreted facies, facies association and paleocurrent direction. Modified from Abatan and Weislogel (2020).

Figure 1-6: Typical facies association A1 outcrop and interpretation of lithofacies and facies association. Hammer is $28 \mathrm{~cm}$ long.

Figure 1-7: Typical facies association A2 outcrop and interpretation of lithofacies and facies association. The notebook is $25 \mathrm{~cm}$ long.

Figure 1-8: Typical facies association A3 outcrop and interpretation of lithofacies and facies association. The notebook is $25 \mathrm{~cm}$ long.

Figure 1-9: A sample exposure of facies association A4 with interpretation of lithofacies and facies association.

Figure 1-10: Outcrop of facies association B4. Lower Kittanning coal bed overlying deformed sandstone body with soft-sediment deformation caused by water escape (Large white arrow) and carbonized root structures (Small red arrows). 
Figure 1-11: Typical outcrop exposure of facies association B1, poorly drained flood plain.

Figure 1-12: Typical outcrop exposure of facies association B2. A) Mudrock deposits of welldrained flood plain overlying channel sandstone. B) Crevasse splay sandstone deposit of facies association B2. Field note $=25 \mathrm{~cm}$.

Figure 1-13: Typical outcrop exposure of facies association B3. A) Coarsening upwards deposits of lacustrine delta facies. B) Outcrop exposure of facies association B3, lacustrine delta facies being onlapped by fine-grained deposits interpreted as lacustrine fines.

Figure 1-14: Outcrop exposure of facies association B4. No. Block coal bed.

Figure 1-15: Ternary plots of modal sandstone grain compositions of channel deposits of the lower MPAF and thin section images. Qt $=$ Quartz, $F=$ Feldspar, $\mathrm{L}=$ Lithic and $\mathrm{M}=$ Mica.

Figure 1-16: Miospore population and MPAF channel styles through time. Image modified from Eble (2002).

Figure 2-1: Study location, Birch River, West Virginia. The gray fill is the MPAF outcrop belt, WV. Dashed Square is the outcrop location.

Figure 2-2: Lithologic Column (Not drawn to scale) and stratigraphic column of the Middle Pennsylvanian Allegheny Formation (MPAF). A) Lithologic column. Study interval includes No. 5 Block, Upper No.5 Block, and Lower Kittanning coal beds and associated clastic deposits (Shaded square). B) Stratigraphic column of the MPAF, Birch River, West Virginia. Lithologic column was modified from Blake et al. (2002) and Cecil et al. (2004). Coal age was from Montañez et al. (2016).

Figure 2-3: The Middle Pennsylvanian Allegheny Formation outcrop, Birch River, West Virginia. A) Outcrop with scale (White bar), position of coal beds and channel belt locations. B) Birch River outcrop with interpreted channel belt boundaries.

Figure 2-4: Workflow for Support Machine Regression (SVR) analysis.

Figure 2-5: Measured sections of channel belt 1 to 4 showing key depositional facies and paleocurrent data. A) Channel belt 1 (CB 1) represents low sinuosity channel deposits. B) Channel belt 2 (CB 2) represents braided channel deposits. C) Channel belt 3 (CB 3) represents high-velocity channel deposits. D) Channel belt 4 (CB 4) represents channel sinuous channel deposits.

Figure 2-6: Variation of mean dune height (hm) and cross-set thickness (Sm), with a Gaussian kernel hyperplane. The support vectors are the data points used by the Gaussian kernel for plotting the best-fitted hyperplane for the regression analysis.

Figure 2-7: Channel belt 1 outcrop. Arrows highlighting truncation of channel bar deposits in Channel belt 1 . Notebook is $25 \mathrm{~cm}$ long. 
Figure 2-8: Example of how direct measurement of preserved bar is measured from outcrop data in Channel belt 4.

Figure 2-9: Fine and medium grained bedform phase diagrams of Rubin and McCulloch, 1980. Estimated range of velocity for channel belt 1 is $85-145 \mathrm{~cm} / \mathrm{sec}$, channel belt 2 is $60-160$ $\mathrm{cm} / \mathrm{sec}$, channel belt 3 is $150-200 \mathrm{~cm} / \mathrm{sec}$ and channel belt 4 is $60-170 \mathrm{~cm} / \mathrm{sec}$.

Figure 2-10: Plot of paleodischarge versus paleoslope of MPAF channels at Birch River, WV. $\mathrm{CB}=$ Channel belt.

Figure 2-11: MPAF channel belts and distribution of numerically significant miospore taxa, Birch River, West Virginia. Miospore data modified from Eble (2002).

Figure 3-1: Study location, West Virginia. Gray area is MPAF outcrop. Yellow area is WVGES Middle Kittanning coal bed coal distribution. Gold stars are core locations. Blue stars are outcrop locations. Labeled locations are used in measured sections and photos. The outcrop data in Ohio is from Stubbs (2018). Shoreline modified from Blakey Maps.

Figure 3-2: Appalachian foreland basin lithostratigraphy. MPAF is shaded area with a dashed outline. Insert is a paleogeographic map of West Virginia area during the Middle Pennsylvanian Images modified from Donaldson et al., 1985; Blakey, 2018.

Figure 3-3: MPAF lithologic column. Modified from Blake et al. (2002), Cecil et al. (2004), and Montañez et al. (2016). Age estimates are from Montañez et al. (2016).

Figure 3-4: Facies association and depositional environments. A) Birch River measured section. B) Tygart Valley river measured section. C) Mylan Park core geologic log (West Virginia Economic Survey ID 306-061). LKC = Lower Kittanning coal, MKC = Middle Kittanning coal, $\mathrm{UKC}=$ Upper Kittanning coal, LFC $=$ Lower Freeport coal and UFC $=$ Upper Freeport coal.

Figure 3-5: Floodplain surface (FS). The flooding surface (Blue dashed line) overlying fluvial channel fill. Tygart Valley River Outcrop, WV. The book is $25 \mathrm{~cm}$.

Figure 3-6: Model section of floodplain and channel depositional environments and floodplain and sequence boundary surfaces. Note that the sequence boundary above the paleosol and below the channel base is the same.

Figure 3-7: Example of sequence stratigraphic boundary interpretation in outcrop. Tygart Valley River, WV.

Figure 3-8: Sequence boundary (SB). Erosional surface (Red dashed line) between sandstone and $\mathrm{MKC}$ coal bed. Tygart Valley river outcrop, WV.

Figure 3-9: Example of paleosol in core data. Nestorville core-WVGES ID 302-072 
Figure 3-10: Example of floodplain surface, sequence boundary and accommodation succession in a lithologic section. Buckhannon core - 285-073, north-central, WV.

Figure 3-11: Sequence stratigraphic correlation of the MPAF.

Figure 3-12: Summary of sequences and depositional tracts of the upper MPAF 


\section{LIST OF TABLES}

Table 1-1: Lithofacies of MPAF.

Table 1-2: Facies Association (FA) (Miall, 1996).

Table 1-3: Model Framework Percent Grain Composition of MPAF Sandstone Deposits.

Table 2-1: Results of Estimated Paleochannel Geometry.

Table 2-2: Results of Estimated Paleogeometry (Channel depth and width), Paleoslope and Paleodischarge.

Table 2-3: Uncertainties for Estimated Fluvial Channel Depth, Slope, Width, Flow Velocity and Discharge.

Table 3-1: Defining Features for High Accommodation System Tracts (HAST) and Low Accommodation System Tracts (LAST) (Catuneanu, 2003; Neal and Abreu, 2009; Atkins, 2016). 


\section{Chapter 1}

\section{Facies Analysis and Depositional Environments of the Lower Allegheny Formation, Appalachian Basin: Implications for Middle Pennsylvanian Paleoclimate}

Oluwasegun Abatan', Amy Weislogel ${ }^{1}$, Bascombe Blake ${ }^{2}$

1) West Virginia University

2) West Virginia Geologic and Economic Survey

Keywords: Sedimentology, fluvial, coal, facies, paleoclimate, Appalachian basin, Allegheny Formation

Submitted to Sedimentary Geology journal 


\section{Abstract}

Fluvial sandstone units of the Middle Pennsylvanian Allegheny Formation (MPAF) above and below the Lower Kittanning coal bed (LKC) show distinctive sedimentary features and mineral composition. These changes coincide with previously modeled periods of paleoclimate change from ever-wet humid climate to a seasonal sub-arid climate, as determined from analysis of coal beds and paleosols of the MPAF. Detailed sedimentologic analysis of the MPAF exposed near Birch River in central West Virginia reveals ten lithofacies that form eight facies associations. These facies associations are interpreted to represent deposits from four environments: 1) fluvial channel deposits (channel fills, channel bar deposits), 2) floodplain overbank deposits, 3) lacustrine delta deposits, and 4) mire deposits (swamp). Fluvial channel facies association and architecture reflect deposition by variable morphology systems, ranging from low-sinuosity, channel forms below the LKC and sinuous channel forms above the LKC. Low-sinuosity channel sandstone deposits contain upper flow regime structures, such as very low angle cross-beds and upper stage plane beds, and lower flow regime structures, such as cross-beds and laminated mudstone, siltstone and sandstone. These channel sandstone deposits exhibit downstream accreting bar elements and occur within interbedded sandstone and siltstone sheets suggesting flow in these channels experienced variable Froude number (i.e. velocity and depth), which is common among fluvial systems that experience highly seasonal discharge. In contrast, channel sandstone deposits above the LKC mainly contain concave upwards sandstone lenses and lateral-accretion bar elements that exhibit lower flow regime indicators (e.g. crossbedding and ripple cross-lamination), along with interbedded sandstone and siltstone sheets which reflects deposition by sinuous, meandering fluvial channels. These channels reflect moderate perennial flow with moderate velocities as reflected by the abundance of lower flow regime structures. Petrographic analysis indicates that the fluvial sandstone deposits below the LKC have higher quartz content (Quartz $=94 \%$ ) than deposits above the LKC (Quartz \% $=74$ $\%)$. Middle Pennsylvanian climate fluctuated from humid ever-wet to seasonally wet-dry. The humid ever-wet climate favors coal formation while the variable discharge structures identified from the channel deposits indicate sedimentary infill was formed by fluvial systems operating in wet-dry seasonal climate conditions.

\section{Introduction}

Climate affects fluvial depositional systems in several ways, primarily through variation in precipitation. Precipitation including volume, rates, and seasonal distribution, control hydrology of flows within fluvial channels and across the floodplain, as well as sediment influx from the source area (Blum and Törnqvist, 2000; Cecil et al., 2003b, 2003a; Miall, 1985). Precipitation also indirectly controls fluvial systems through effects from vegetative cover; regions with arid climates have reduced vegetative cover leading to higher rate of erosion and increased sediment influx in surrounding during precipitation, well as relatively larger reworking of fluvial deposits (Blum and Törnqvist, 2000; Miall, 1996; Schumm, 1988, 1981).

In the Late Paleozoic Alleghany foreland basin, paleoclimate changed from humid everwet conditions during the Early Pennsylvanian, to semi-arid conditions during the Late 
Pennsylvanian (Cecil, 1990; Cecil et al., 2003a; Cecil and Dulong, 2003; DiMichele et al., 2010; Falcon-Lang and DiMichele, 2010; Kosanke and Cecil, 1996; Montañez et al., 2016). The associated changes in precipitation potentially influenced the hydrology of fluvial systems, generating a signal of climatic change in the sedimentology and facies patterns of sediment preserved in depocenters of the Allegheny foreland basin (e.g., Blum and Törnqvist, 2000; Cecil et al., 2003b; Miall, 1985). Such a signal has been observed from palynological and paleobotanical study of Pennsylvanian coal seams, which found lysosomes fungal spores, which are common in humid, ever-wet environments, overall decreased during the Pennsylvanian, whereas herbaceous fern plant spores, which are common in less humid environments, became more abundant (Cecil et al., 1985; DiMichele et al., 2010; Falcon-Lang and DiMichele, 2010; Kosanke and Cecil, 1996; Peppers, 1996). Lithologic climate indicators, such as calcareous paleosols, which are indicative of more arid environments, are abundant in the uppermost Middle and most of the Upper Pennsylvanian deposits, whereas siderite, which commonly develops in humid environments, are more abundant in Lower and lower Middle Pennsylvanian. Together, these data indicate increased aridity during the Pennsylvanian (Cecil, 1990; Cecil et al., 1985; Cecil and Dulong, 2003; Donaldson and Shumaker, 1981).

This change in precipitation, as an allogenic control on Pennsylvanian fluvial depositional systems, should have also influenced the resulting facies and stratigraphic architecture of fluvial deposits (Allen et al., 2014; Fielding et al., 2009; Gibling et al., 2014; Plink-Björklund, 2015). The architecture and internal lithofacies of fluvial deposits permit the interpretation of changing fluvial flow conditions (Allen, 1979; Allen et al., 2011b; Fielding et al., 2009); in this way, facies architecture and hence fluvial styles can document the response of fluvial landscapes to climatic variation as indicated by regional coal studies and coal paleobotany (Allen et al., 2014; Cecil, 1990; Cecil et al., 2003b; Fielding et al., 2009; Greb et al., 2008; Holbrook and Schumm, 1999; Matthews and Perlmutter, 1994; Miall, 1996; Olsen et al., 1994). However, very little information is available for Pennsylvanian fluvial systems of the Allegheny foreland basin to assess their sensitivity in responding to late Paleozoic glacial-interglacial climate changes. The recognition of fluvial styles in the Allegheny foreland basin should aid in understanding the stratigraphic architectures influenced by precipitation variation during glacial-interglacial climate change.

The Middle Pennsylvanian (Desmoinian) Allegheny Formation (MPAF) is a northwest prograding sedimentary succession within the Alleghenian foreland basin (Donaldson and Shumaker, 1981), composed of sandstone, coal, mudrock and minor limestone beds (Arkle Jr et al., 1979). The facies architecture of MPAF deposits was analyzed to evaluate the change in fluvial styles coincident with documented changes in paleoclimate and precipitation patterns (Allen et al., 2011b; Blum and Törnqvist, 2000; Cecil, 1990; Cecil et al., 2003b, 1985; Davies et al., 2011; Fielding et al., 2009; Greb et al., 2008). Fluvial patterns were identified through detailed sedimentologic and architectural analysis of lower MPAF strata, which crop out near the town of Birch River, West Virginia. The sedimentology of MPAF fluvial sandstone deposits are compared to facies models of fluvial systems developed in a range of climatic settings, in order to assess the fluvial response to Middle Pennsylvanian allogenic drivers.

\section{Basin Setting and Stratigraphy}


The collision of Laurasia and Gondwanaland ( $\sim 325 \mathrm{Ma})$ initiated the Alleghenian orogeny which was characterized by collision and compressional deformation structures that formed the Allegheny fold-thrust belt (Donaldson and Shumaker, 1981; Ettensohn, 2008, 2005; Sak et al., 2012). The Alleghenian orogeny resulted in the formation of a broad shallow foreland basin (Ettensohn, 2008, 2005). The central Allegheny foreland basin subsided, adjacent to the Allegheny fold-thrust belt, preserving a thick succession of Upper Paleozoic, cratonwardprograding syn-orogenic clastic sediment shed from the orogenic highlands. The MPAF is part of this succession and is characterized by multi-story sandstone bodies with variably interbedded paleosol, coal, limestone or marine shale deposits, forming stacked successions termed cyclothems (Fig. 1-1) (Arkle Jr et al., 1979; Blake et al., 2002; Cecil, 1990; Donaldson and Shumaker, 1981). The term cyclothem is based on eustatic models that suggest repetitive deposition of upward-shoaling clastics capped by coal beds due to regression-transgression cycles driven by glacio-eustatic sea-level fall and rise (Arkle Jr et al., 1979; DiMichele et al., 2010; Falcon-Lang, 2004; Greb et al., 2008). During these glacio-eustatic cycles, paleoclimate shifted from ever-wet humid climate during interglacial periods to a seasonal semi-arid/ subhumid climate during glacial periods (Falcon-Lang and Dimichele, 2010). Glacial-interglacial paleoclimate influenced climate conditions of the low paleo-latitudinal position of the Allegheny foreland basin by altering Hadley Cell circulation patterns along the Intertropical Convergence Zone (ITCZ). The equatorial position of the ITCZ during glacial periods caused high rainfall in the Allegheny foreland, whereas the northward drift of the ITCZ during interglacial caused greater seasonality of rainfall, with several months of high precipitation followed by several months of dry, sub-arid conditions each year (Cecil et al., 2004, 2003b; Poulsen et al., 2007).

The MPAF contains several coal members that formed during ever-wet, humid/ per humid conditions (from stratigraphically oldest to youngest): Stockton coal, Little No. 5 Block, No.5 Block, Upper No.5 Block, Lower Kittanning (No. 6 Block Coal), Middle Kittanning, Upper Kittanning, Lower Freeport and Upper Freeport coal beds (Fig. 1-1 and Fig. 1-2) (Arkle Jr et al., 1979; Blake et al., 2002; Repine et al., 1993). Regionally, calcic paleosol are sometimes associated with coal beds of the MPAF, typically the Middle Kittanning, Upper Kittanning, and Lower Freeport coals (Cecil, 1990). The siliclastic members of the MPAF generally are composed of coarsening-upward, fine to coarse-grained sandstone with minor gravel, interpreted as fluvial sandstone deposits (Arkle Jr et al., 1979; Cecil, 2013; Donaldson and Shumaker, 1981; Ettensohn, 2005; Repine et al., 1993). The Freeport lacustrine limestone and other minor limestone beds are interpreted to have been formed in a lacustrine environment during semi-arid climatic conditions (Arkle Jr et al., 1979; Blake et al., 2002; Cecil, 1990; Donaldson et al., 1985).

This study focuses on a large ( $45 \mathrm{~m}$ thick and $495 \mathrm{~m}$ wide) road cut through the lower part of the Middle Pennsylvanian Allegheny Formation, from here on referred to as lower MPAF, which is exposed along US Route 19 at the Birch River, West Virginia (Powell Mountain) outlook area (Fig. 1-2 and Fig. 1-3). At Birch River, the MPAF conformably overlies the Kanawha Formation and is overlain by the Conemaugh Formation (Donaldson and Eble, 1991; Eble, 2002; Falcon-Lang et al., 2011). Units of MPAF present in the Birch River road cuts include the No. 5 Block coal bed, Upper No. 5 Block coal bed, the Lower Kittanning (LKC) coal beds and interbedded siliclastic units (Fig. 1-1-1-3). Here, the siliclastic units of the MPAF lack evidence of marine influence, and regional stratigraphic correlations indicate the shoreline was 
located $\sim 140 \mathrm{~km}$ towards the west in southeastern Ohio (Belt et al., 2011; Stubbs, 2018), and 170 $\mathrm{km}$ towards the north in southwestern Pennsylvania (Blakey, 2018; DiMichele, 2013).

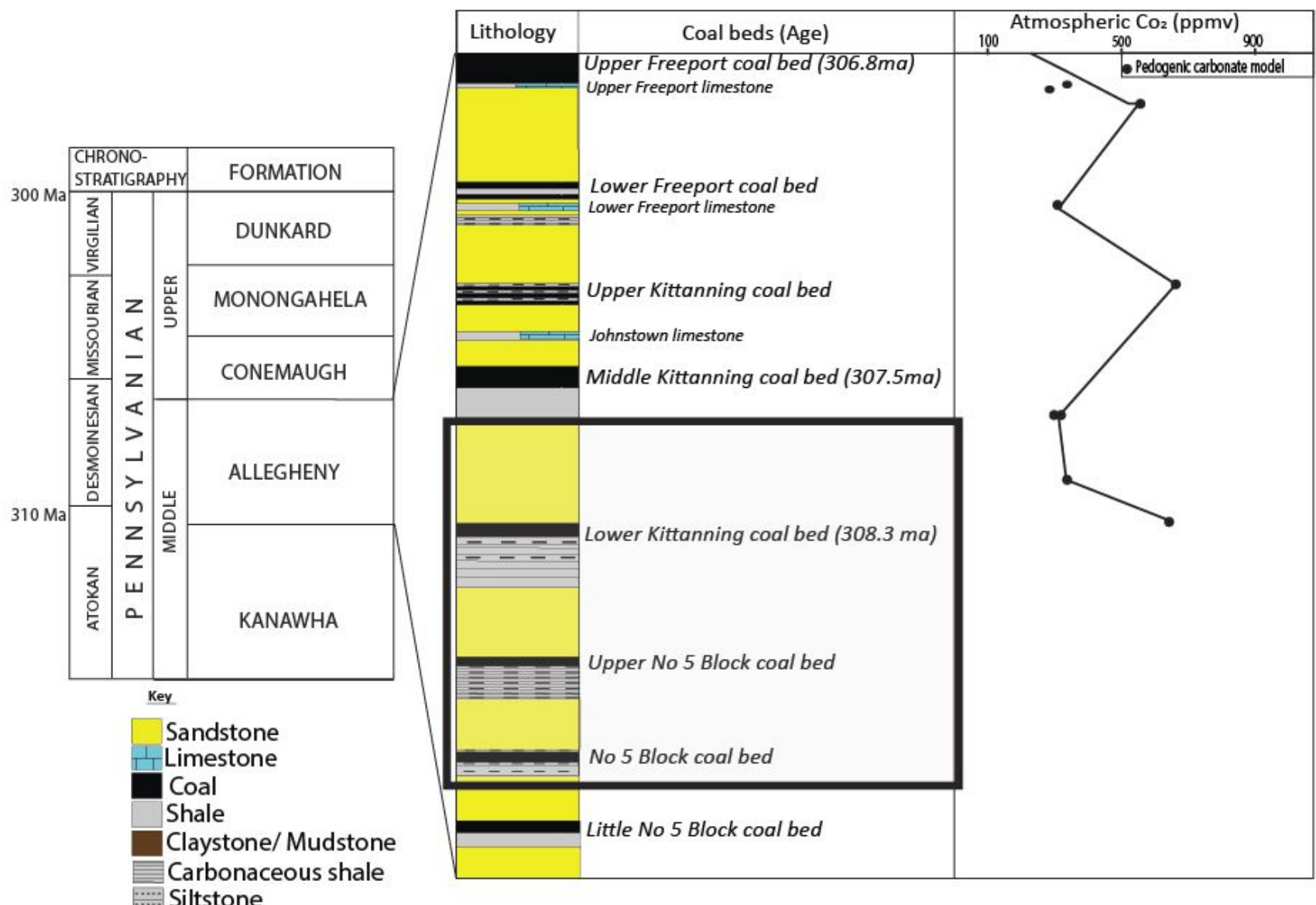

Figure 1-1: Simplified chronostratigraphic column. Study interval includes No. 5 Block, Upper No.5 Block, and Lower Kittanning coal beds and associated clastic deposits (red square). Modified from Blake et al. (2002), Cecil et al. (2004), Montañez et al. (2016) and Abatan and Weislogel (2020). 


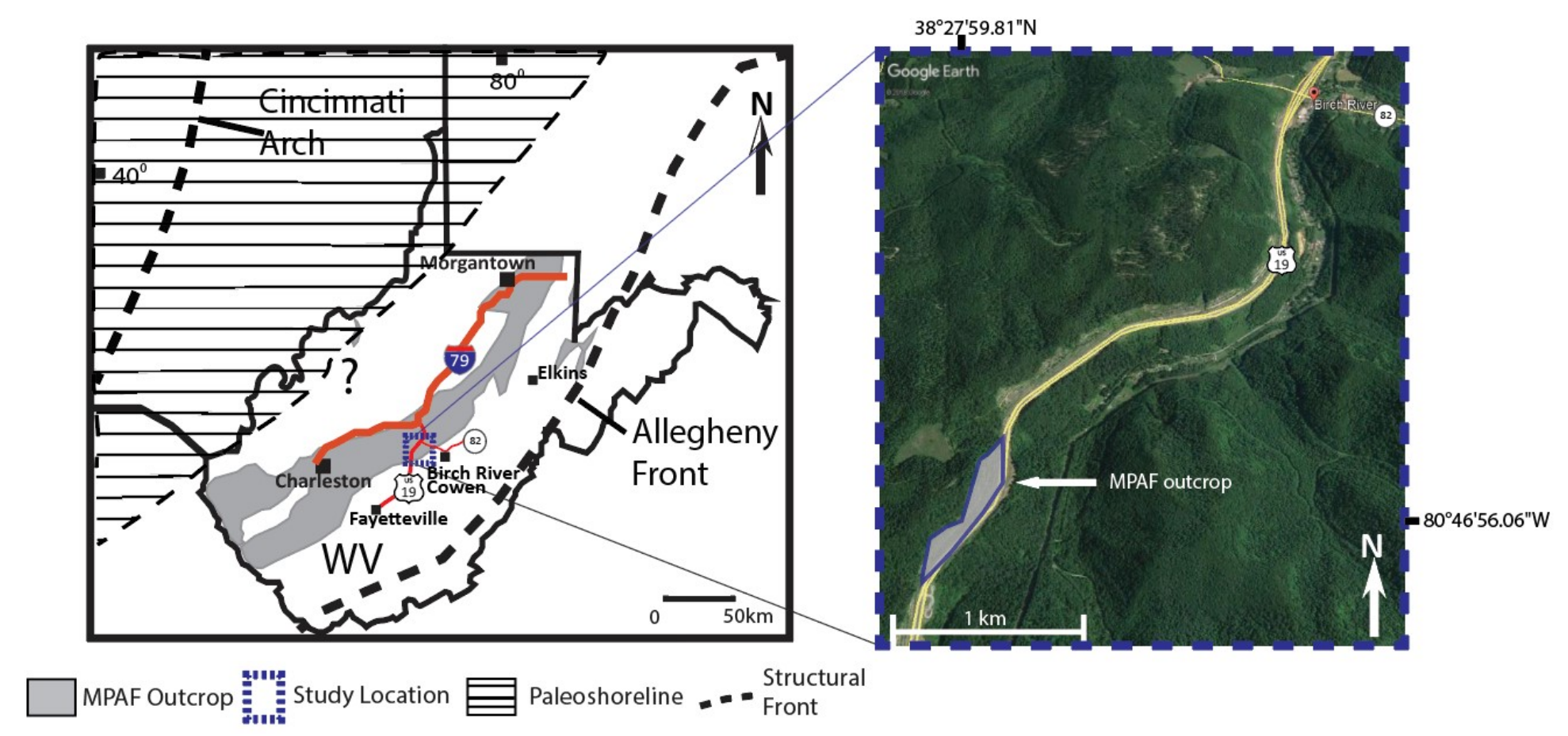

Figure 1-2: Location of study area. Map of West Virginia with geologic map of MPAF outcrop and study area. 


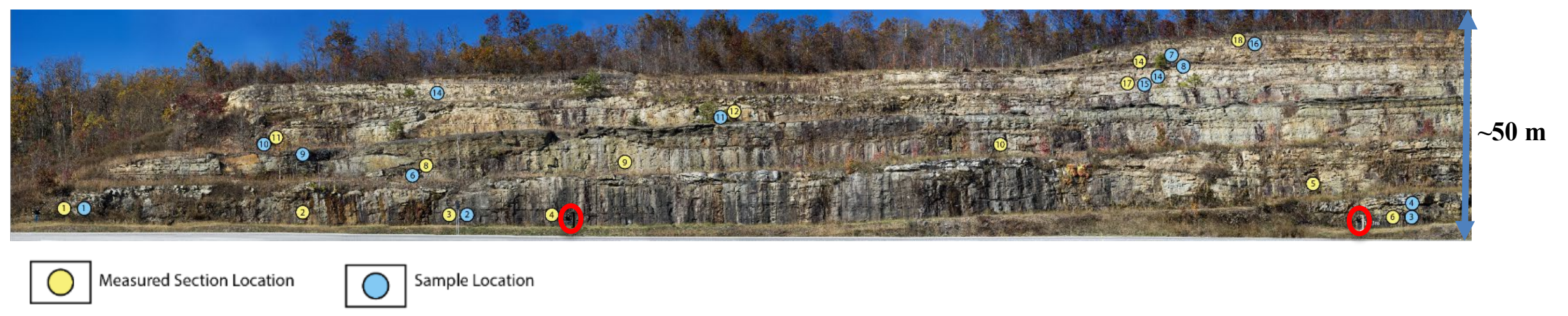

Figure 1-3: Section of the lower part of the Middle Pennsylvanian Allegheny Formation used for this study at Powell Mountain, Birch River West Virginia. Numbered circles are locations of some samples and measured section. See $\sim 2 \mathrm{~m}$ tall person for scale. (red circles). 


\section{Methods and Analytical Techniques}

We collected 18 detailed measured sections from across the total width of the outcrop (495 $\mathrm{m})$; these measured sections were used to construct a composite section for the entire exposure. Measured section data were used to define facies and facies associations. Facies were defined using the Miall's (1996) facies code system (Table 1-1). Information acquired for the measured sections includes bed lithology, thickness, fossil content, grain size, color, sedimentary structures, and paleocurrent orientation. Facies were grouped into genetically-related facies associations based on mapping facies boundaries and lithofacies stacking relationships (Miall, 2014; 1996). Architectural element analysis, which is the lateral and/ or vertical stacking of bedforms that share common bounding surfaces (Miall, 1996), was used to interpret the evolution of macroforms preserved in the MPAF. Depositional environments and fluvial styles of the MPAF were interpreted from the lithofacies and facies association (Allen, 1979; Fielding et al., 2009; Miall, 2014). Dominant controls on depositional processes of the MPAF were inferred from interpreted fluvial styles (Allen, 1979; Allen et al., 2011a; Bhattacharya and Tye, 2004; Fielding et al., 2009; Miall, 2014). Bankfull flow depths were estimated from bar and cross-set thickness of MPAF channel deposits. In addition to sedimentologic data, the petrographic composition of sandstone units of MPAF in the Birch River study location was determined by point-counting 13 thin-sections of medium to coarse-grained sandstone. The thinsections used for the analysis were sampled from medium to coarse-grained sandstone. At least 300 points were counted using the modified Gazzi-Dickinson method (Ingersoll et al., 1984). All the samples used are moderately sorted with sub-rounded to sub-angular grains. All thin-sections were stained for potassium feldspar (K-feldspar) and calcium plagioclase. Normalized modal framework grain abundances were plotted on ternary diagrams following Dickinson (1985) and using the plotting program of Zahid and Barbeau (2011) to interpret changes in sediment source area over the duration of MPAF fluvial system evolution. 
Table 1-1: Lithofacies of MPAF

\section{Lithofacies Lithology}

\section{Physical Bed Features \\ Structures}

Transportation and Depositional Process
Interpretation

and

Environment of

Deposition

\begin{tabular}{|c|c|c|c|c|c|}
\hline$S m$ & $\begin{array}{l}\text { Poorly to moderately } \\
\text { well sorted, sub- } \\
\text { angular, coarse to } \\
\text { fine-grained, gray } \\
\text { sandstone. } \\
\text { Ferruginized in } \\
\text { places. }\end{array}$ & $\begin{array}{l}\text { Appears } \\
\text { massive. }\end{array}$ & $\begin{array}{l}\text { Sandstone beds may be } \\
\text { horizontal or inclined. } \\
\text { Sandstone bed thicknesses } \\
\text { range from } 30-120 \mathrm{~cm} \text {. } \\
\text { Sand body extends laterally } \\
\text { for } \sim 1->10 \mathrm{~m} \text {. Sandstone } \\
\text { bedding plane is planar or } \\
\text { curved surface that may be } \\
\text { gradational or sharp, } \\
\text { forming planar and } \\
\text { lenticular shaped sandstone } \\
\text { bodies }\end{array}$ & $\begin{array}{l}\text { Bedload deposition } \\
\text { under unclear } \\
\text { conditions. May have } \\
\text { been deposited by } \\
\text { lower or upper stage } \\
\text { flow current. }\end{array}$ & $\begin{array}{l}\text { Channel fill. } \\
\text { Deposited within } \\
\text { Channel or channel } \\
\text { overbank. } \\
\text { Channel bar or } \\
\text { thalweg deposit. } \\
\text { Occurs as isolated } \\
\text { or chute channels } \\
\text { in a floodplain. }\end{array}$ \\
\hline Sh & $\begin{array}{l}\text { Poorly to moderately } \\
\text { sorted, sub-angular } \\
\text { to angular, medium } \\
\text { to fine-grained gray } \\
\text { sandstone. Contains } \\
\text { up to pebble size } \\
\text { floating coal and } \\
\text { siderite clast, plant } \\
\text { logs and debris in } \\
\text { some places. }\end{array}$ & $\begin{array}{l}\text { Horizontal } \\
\text { lamination. }\end{array}$ & $\begin{array}{l}\text { Occurs as laminae or } \sim 1 \\
\mathrm{~cm} \text { thick bed set. Laminae } \\
\text { and bed may extend for } \\
\sim 0.10->100 \mathrm{~m} \text {. Laminae } \\
\text { and bedding planes may be } \\
\text { curved or planar. Bedding } \\
\text { planes are mostly sharp and } \\
\text { wavy in some places. }\end{array}$ & $\begin{array}{l}\text { Bedload deposited } \\
\text { under upper flow } \\
\text { regime currents. }\end{array}$ & $\begin{array}{l}\text { Channel fill or } \\
\text { flood sheet. }\end{array}$ \\
\hline
\end{tabular}




\section{Lithofacies Lithology}

\section{Physical Structures \\ Bed Features}

Transportation and Depositional Process
Interpretation

and

Environment of

Deposition

\begin{tabular}{|c|c|c|c|c|c|}
\hline$S l$ & $\begin{array}{l}\text { Poorly sorted, sub- } \\
\text { angular to angular, } \\
\text { fine to medium- } \\
\text { grained sand. Gray- } \\
\text { colored sandstone. } \\
\text { Contains mica. }\end{array}$ & $\begin{array}{l}\text { Very low } \\
\text { angle cross- } \\
\text { lamination. }\end{array}$ & $\begin{array}{l}\text { Convex upward sandstone } \\
\text { beds with planar lamina } \\
\text { forming } \sim 1 \mathrm{~cm} \text { thick bed } \\
\text { sets. Laminae and bed may } \\
\text { extend for } \sim 0.1-0.9 \mathrm{~m} \text {. } \\
\text { Bedding planes are planar } \\
\text { and mostly form sharp } \\
\text { contacts. }\end{array}$ & $\begin{array}{l}\text { Bedload deposition } \\
\text { during upper flow } \\
\text { regime. Bed erosion } \\
\text { and sediment } \\
\text { deposition during } \\
\text { supercritical high } \\
\text { energy flow event as } \\
\text { antidunes or washed } \\
\text { out dunes. }\end{array}$ & $\begin{array}{l}\text { Antidunes or } \\
\text { washed out dunes. } \\
\text { Channel thalweg. }\end{array}$ \\
\hline$S p$ & $\begin{array}{l}\text { Poorly to moderately } \\
\text { sorted, sub-angular, } \\
\text { fine to medium- } \\
\text { grained sand gray or } \\
\text { light gray sandstone. } \\
\text { Contains granular } \\
\text { siderite and coal clast } \\
\text { in some places. } \\
\text { Contains rootlets in } \\
\text { some places. }\end{array}$ & $\begin{array}{l}\text { Planar cross- } \\
\text { stratification. }\end{array}$ & $\begin{array}{l}\text { The planar bed sets may be } \\
\text { horizontal, inclined, } \\
\text { lenticular or sigmoidal. } \\
\text { Occurs as co-sets of } \\
\text { multiple planar cross-bed } \\
\text { sets or both planar and } \\
\text { trough cross-bedded sets. } \\
\text { Bed thickness range from } \\
\sim 10-100 \mathrm{~cm} \text {. Beds can } \\
\text { extend laterally for } \sim 0.5 \text { - } \\
>100 \text { m. Bedding planes } \\
\text { may be curved or planar } \\
\text { with mostly sharp surfaces, } \\
\text { but surfaces can be } \\
\text { gradational in places. May }\end{array}$ & $\begin{array}{l}\text { Bedload deposit of } \\
\text { channelized lower flow } \\
\text { regime currents. The } \\
\text { direction of the inclined } \\
\text { bed indicates the } \\
\text { direction of flow and } \\
\text { sediment transport. }\end{array}$ & $\begin{array}{l}\text { Transverse (2-D) } \\
\text { dune. Deep } \\
\text { channel bars or } \\
\text { channel thalweg. }\end{array}$ \\
\hline
\end{tabular}


Physical

\section{Structures}

Bed Features

Transportation and Depositional

Process
Interpretation

and

Environment of

Deposition

\begin{tabular}{|c|c|c|c|c|c|}
\hline & & & $\begin{array}{l}\text { also occur as a contorted } \\
\text { bed set. }\end{array}$ & & \\
\hline$S t$ & $\begin{array}{l}\text { Poorly to moderately } \\
\text { well sorted, sub- } \\
\text { angular, fine to } \\
\text { medium-grained gray } \\
\text { or light gray } \\
\text { sandstone. Contains } \\
\text { granular siderite and } \\
\text { coal clast in some } \\
\text { places. Contains } \\
\text { rootlets in some } \\
\text { places. }\end{array}$ & $\begin{array}{l}\text { Trough cross- } \\
\text { stratification. }\end{array}$ & $\begin{array}{l}\text { Beds may be horizontal, } \\
\text { inclined, lenticular or } \\
\text { sigmoidal. Occurs as co-sets } \\
\text { of multiple trough cross-bed } \\
\text { sets or both planar and } \\
\text { trough cross-bedded sets. } \\
\text { Bed thickness range from } \\
\sim 10-60 \mathrm{~cm} \text {. Beds can } \\
\text { extend laterally for } \sim 0.5 \text { - } \\
>100 \text { m. Bedding planes } \\
\text { may be curved or planar } \\
\text { mostly sharp surfaces but } \\
\text { can be gradational in places. } \\
\text { Beds are amalgamated in } \\
\text { some places. May also } \\
\text { occur as a contorted bed set. }\end{array}$ & $\begin{array}{l}\text { Bedload deposition by } \\
\text { 3-D dunes developed in } \\
\text { lower flow regime } \\
\text { current. }\end{array}$ & $\begin{array}{l}\text { Channel thalwag } \\
\text { and channel bar. }\end{array}$ \\
\hline Ss & $\begin{array}{l}\text { Poorly sorted, } \\
\text { rounded to } \\
\text { subangular, silt to } \\
\text { pebble-grained, gray- } \\
\text { colored mudrock and } \\
\text { coarse-grained }\end{array}$ & $\begin{array}{l}\text { Broad } \\
\text { horizontal or } \\
\text { cross- } \\
\text { stratification. }\end{array}$ & $\begin{array}{l}\text { Beds may be planar or } \\
\text { lenticular. Beds are mainly } \\
\text { horizontal but may be } \\
\text { slightly inclined in some } \\
\text { places. Bed thickness } \\
\text { ranges from } \sim 0.1-100 \mathrm{~cm} \text {. }\end{array}$ & $\begin{array}{l}\text { Bedload deposited by } \\
\text { lower flow regime } \\
\text { current. Larger pebble } \\
\text { size sediments are } \\
\text { transported via traction } \\
\text { along channel floor and }\end{array}$ & $\begin{array}{l}\text { Channel thalweg } \\
\text { scour fill. }\end{array}$ \\
\hline
\end{tabular}




\begin{tabular}{|c|c|c|c|c|c|}
\hline & $\begin{array}{l}\text { sandstone with } \\
\text { pebble intraclast. }\end{array}$ & & $\begin{array}{l}\text { Beds can extend laterally } \\
\text { for } \sim 1->10 \text { m Bedding } \\
\text { plane are mostly planar, } \\
\text { sharp and erosional but may } \\
\text { be gradational. }\end{array}$ & $\begin{array}{l}\text { deposited as channel } \\
\text { lag deposits during } \\
\text { waning flow. }\end{array}$ & \\
\hline$S r$ & $\begin{array}{l}\text { Poorly sorted, fine to } \\
\text { medium-grained } \\
\text { gray-colored } \\
\text { sandstone. Contains } \\
\text { pyrite and micas in } \\
\text { some places. } \\
\text { Sometimes contains } \\
\text { up to pebble size } \\
\text { coal and pebble- } \\
\text { sized siderite clasts. }\end{array}$ & $\begin{array}{l}\text { Small-scale } \\
(<1 \mathrm{~cm} \text { thick }) \\
\text { cross- } \\
\text { stratification. }\end{array}$ & $\begin{array}{l}\text { Bed thickness range from } \\
<\sim 1 \mathrm{~cm} \text { to } 15 \mathrm{~cm} \text {, with bed } \\
\text { co-sets reaching up to } \sim 1 \mathrm{~m} \\
\text { thickness. Beds can extend } \\
\text { laterally for } \sim 1 \text { to }>100 \mathrm{~m} \text {. } \\
\text { Bedding plane contacts are } \\
\text { mainly sharp and planar but } \\
\text { can be undulating in some } \\
\text { places. Beds may also occur } \\
\text { as a contorted laminae set. }\end{array}$ & $\begin{array}{l}\text { Bedload deposited by } \\
\text { lower flow regime } \\
\text { currents. }\end{array}$ & $\begin{array}{l}\text { Deposited within } \\
\text { channel thalweg or } \\
\text { as channel } \\
\text { barforms. }\end{array}$ \\
\hline$F l$ & $\begin{array}{l}\text { Siltstone and } \\
\text { claystone. Siltstones } \\
\text { are gray in color. } \\
\text { Claystone includes } \\
\text { brown to gray- } \\
\text { mudstone and gray } \\
\text { or black shale. The } \\
\text { shale beds are platy } \\
\text { to friable in places. }\end{array}$ & $\begin{array}{l}\text { Interlaminated } \\
\text { siltstone and/ } \\
\text { or claystone. }\end{array}$ & $\begin{array}{l}\text { Bedding thickness range } \\
\text { from } \sim 0.20-5 \mathrm{~m} \text {. Beds can } \\
\text { extend laterally from } \sim 2- \\
>100 \mathrm{~m} \text {. The siltstones are } \\
\text { planar and occur mainly as } \\
\text { horizontal beds. The } \\
\text { mudstones are lenticular or } \\
\text { planar geometry. The shale } \\
\text { beds are planar horizontal. }\end{array}$ & $\begin{array}{l}\text { Suspended load } \\
\text { deposited by waning } \\
\text { flow. }\end{array}$ & $\begin{array}{l}\text { Overbank, } \\
\text { vegetated flood } \\
\text { plain or swamp. }\end{array}$ \\
\hline
\end{tabular}




\begin{tabular}{|c|c|c|c|c|c|}
\hline & $\begin{array}{l}\text { Contains rootlets and } \\
\text { plant debris in some } \\
\text { places. May contain } \\
\text { iron concretions. } \\
\text { Contains plant } \\
\text { fossils. }\end{array}$ & & $\begin{array}{l}\text { May also occur as contorted } \\
\text { laminae or bed. }\end{array}$ & & \\
\hline$F m$ & $\begin{array}{l}\text { Siltstone, mudstone, } \\
\text { and claystone. } \\
\text { Siltstones are gray in } \\
\text { color. Mudstone and } \\
\text { claystone are brown } \\
\text { or gray-colored. }\end{array}$ & $\begin{array}{l}\text { Massive } \\
\text { siltstone, } \\
\text { mudstone, and } \\
\text { claystone } \\
\text { beds. }\end{array}$ & $\begin{array}{l}\text { The siltstone beds are } \\
\text { planar, while the mudstone } \\
\text { and claystone beds are } \\
\text { planar or lenticular. The } \\
\text { claystone body thickness } \\
\text { ranges from } 0.05 \text { to } .15 \mathrm{~m} \text {. } \\
\text { Claystone body may extend } \\
\text { laterally for } \sim 0.10->10 \mathrm{~m} \text {. } \\
\text { Mudrock occurs as a lens } \\
\text { overlying interbedded } \\
\text { siltstone or shale. }\end{array}$ & $\begin{array}{l}\text { Suspended load } \\
\text { deposited by } \\
\text { slackwater. }\end{array}$ & $\begin{array}{l}\text { Vegetated } \\
\text { floodplain or } \\
\text { swamp. Mud } \\
\text { drapes or } \\
\text { abandonment plug. }\end{array}$ \\
\hline$C$ & $\begin{array}{l}\text { Dark gray to black } \\
\text { color. Dull or } \\
\text { shinning in some } \\
\text { places. Contains clay } \\
\text { to silt-sized partings }\end{array}$ & $\begin{array}{l}\text { Massive to } \\
\text { blocky coal } \\
\text { beds. }\end{array}$ & $\begin{array}{l}\text { Coal beds are horizontal } \\
\text { and may have planar or } \\
\text { lenticular geometry. }\end{array}$ & $\begin{array}{l}\text { Deposits of vegetation } \\
\text { debris during high } \\
\text { water levels and low } \\
\text { sediment supply. }\end{array}$ & $\begin{array}{l}\text { Vegetated } \\
\text { floodplain peat } \\
\text { swamp (mire). }\end{array}$ \\
\hline
\end{tabular}




\section{Lithofacies Lithology}

Physical Bed Features

Structures
Transportation

and Depositional

Process
Interpretation

and

Environment of

Deposition

in most places. Rare

intergranular silt/

mud. 


\section{$5 \quad$ Results and Interpretation}

\subsection{Lithofacies Description and Hydrologic Interpretation}

Ten unique lithofacies were identified within the MPAF at the study location (Fig. 1-4) and include: massive structureless sandstone, horizontal planar laminated sandstone, low-angle crossbedded sandstone, planar cross-stratified sandstone, trough cross-stratified sandstone, poorlysorted sandstone, ripple laminated sandstone, interbedded sandstone, siltstone and mudrock, massive siltstone and mudrock, and coal (Fig. 1-4). The composite stratigraphic column reflects four sandstone units within the MPAF succession at Birch River (Fig. 1-5). Table 1-1 gives a summary of the description, the process of formation, and interpretation of the depositional environment of each lithofacies, which is expanded upon below.

\subsubsection{Massive Sandstone (Sm)}

The massive sandstone facies is characterized by coarse- to fine-grained, poorly to moderately well sorted, gray-colored, massive sandstone with no apparent internal stratification. Sandstone is composed of quartz, feldspar, micas and dark lithic fragments. The sandstone contains medium to coarse-grained sand and abundant coal intraclasts in some places. Beds range from $\sim 0.3-1.2 \mathrm{~m}$ thick and often exhibit lenticular and/or planar geometry and may be inclined or horizontal. The lack of an identifiable sedimentary structure may be due to outcrop surface weathering and crude sorting. Grain-size indicates energetic turbulent currents first scoured the substrate to form the sharp basal surface, then deposited sediment infill. This infill may have been within individual channels of a fluvial channel belt.

\subsubsection{Horizontal Planar-stratified Sandstone (Sh)}

The horizontal planar-stratified sandstone is characterized by poorly to moderately sorted, sub-angular to angular, medium to fine-grained gray-colored sand. Sandstone may contain floating coal intraclasts, with small plant debris and logs up to $0.15 \mathrm{~m}$ long present in some places. Sandstone beds may also contain sub-rounded siderite nodule intraclasts up to $1 \mathrm{~cm}$ in diameter. Beds have planar geometry and contain horizontal laminae up to $\sim 1 \mathrm{~cm}$ thick. Bed sets are $\sim 1-50 \mathrm{~cm}$ thick, laterally discontinuous, and may extend for $\sim 0.10->10 \mathrm{~m}$. Lower and upper bedding planes are mostly sharp and horizontal but upper bedding planes may be wavy in some places. Horizontal planar lamination and large siderite clasts reflect bedload deposition by upper flow regime current mostly within a broad, shallow channel as indicated by the geometry of the basal bedding plane, and bed thickness.

\subsubsection{Low-angle Cross-stratified Sandstone (SI)}

This facies is characterized by poorly sorted, sub-angular to angular, medium-grained, gray-colored sandstone composed of quartz, feldspar, and lithics. Sandstone exhibits very low angle cross-laminae within convex upward sandstone beds up to $5 \mathrm{~cm}$ thick, consistent with formation by anti-dune bedform migration. Beds may extend for $\sim 0.1-0.9 \mathrm{~m}$. Bedding contacts are mostly sharp and horizontal but are gradational in some places. The low-angle cross-stratified sandstone is formed from bedload deposition by supercritical flow, in which antidunes were periodically developed then washed out. The Sl sandstone facies is interpreted to represent 
thalweg deposition in a broad, shallow channel as indicated by extensive, continuous bedding planes and low bed thickness.

\subsubsection{Planar Cross-stratified Sandstone (Sp)}

This facies is characterized by poorly to moderately sorted, sub-angular, fine to mediumgrained, gray or light gray-colored sandstone. The sandstone contains up to pebble-sized, subrounded siderite and angular coal intraclasts in some places. Internal features of the sandstone beds are made up of planar cross-stratified sandstone. The sandstone beds may be planar, lenticular or wedge-shaped. Most of the beds are horizontal but may be inclined in some places. Bed thickness range from $\sim 10-100 \mathrm{~cm}$. Beds can extend laterally for $\sim 0.5->10 \mathrm{~m}$. Bedding planes are mostly sharp but can be gradational or erosional in some places. The Sp beds contain rootlets in some places. Sandstone deposits exhibit large scale $(>2 \mathrm{~m})$ soft-sediment deformation features in some places, such as contorted beds. The planar cross-stratified sandstone units are derived from bedload deposition by lower flow regime currents, which resulted in the formation of transverse (2-D) dune. The dip direction of cross-beds indicates flow towards the north to northwest. The sandstone beds were interpreted to represent deposition either within a broad deeper part of the channel thalweg or channel bar as indicated by the continuity and planar geometry of bedding planes and erosive basal scours.

\subsubsection{Trough Cross-stratified Sandstone (St)}

This facies is similar to the planar cross-stratified sandstone ( $\mathrm{Sp}$ ) facies, except it exhibits trough cross-stratification. Like the $\mathrm{Sp}$ facies, the trough cross-stratified sandstone $(\mathrm{St})$ is characterized by poorly to moderately well sorted, sub-angular, fine to medium-grained, gray or light gray-colored sand. Sandstone may contain siderite nodules and/ or coal intraclasts in some

places. Bed thickness range from $\sim 10-60 \mathrm{~cm}$. Beds can extend laterally for $\sim 0.5->100 \mathrm{~m}$. Beds may be planar, lenticular or wedged, horizontal or inclined with sharp, horizontal or troughshaped bedding plane. Bedding contacts may be gradational or erosional surfaces in some places. Most sandstone beds are amalgamated and may also occur as contorted bed set in some places. Sandstone contains rootlets in some places. The trough cross-stratified sandstone beds are bedload deposited by lower flow regime currents, which result in the formation of 3-D dunes. The direction of the inclined bed indicates the direction of flow and sediment transport is towards the northwest. Sandstone beds were interpreted to be deposited within broad, deeper part of the channel thalweg and channel bars, similar to the Sp facies except under flow conditions with slightly greater shear stress to generate 3D dunes instead of $2 \mathrm{D}$ dunes.

\subsubsection{Poorly-sorted Sandstone (Ss)}

This facies is characterized by poorly sorted, rounded to subangular, very fine to very coarse-grained, gray-colored sand with abundant pebble-sized quartz intraclast. The sandstone may contain planar or lenticular, horizontal or inclined beds with sharp, horizontal or curved bedding planes forming composite erosional surfaces. Bed thickness ranges from $\sim 0.1-100 \mathrm{~cm}$. Beds can extend laterally for $\sim 1->10 \mathrm{~m}$. The Ss facies represents rapid deposition by waning lower or upper flow regime currents within a channel of variable width, from $1->10 \mathrm{~m}$ as indicated by the continuity of basal scours and overlying beds. Pebble-sized sediments are 
transported via traction and deposited alongside other materials during waning flow. The sandstone is interpreted to have been deposited by gravity/ debris flow on the channel thalweg.

\subsubsection{Ripple Laminated Sandstone (Sr)}

This facies is characterized by poorly sorted, fine to medium-grained sand, gray and brown-colored sandstone. Sandstone contains coal, siderite, pyrite and micas intraclasts in some places. Laminae are mainly asymmetrical. Laminae sets occurs mainly as planar shaped, horizontal laminas, with sharp, undulating, horizontal bedding plane. The sandstone beds range in thickness from $<\sim 1 \mathrm{~cm}-\sim 15 \mathrm{~cm}$ with bed co-sets reaching up to $1 \mathrm{~m}$. The $\mathrm{Sr}$ beds are laterally discontinuous and can extend laterally for $\sim 1->10 \mathrm{~m}$. The Sr bedform suggests bedload deposited by lower flow regime currents. The ripple laminated sandstone beds were interpreted to have been deposited within shallow channels, or on other channel bedforms/ barforms, as indicated by the lateral variation in $\mathrm{Sr}$ bed continuity.

\subsubsection{Interbedded Siltstone and Claystone (Fl)}

This facies is characterized by interlaminated siltstone, mudstone, claystone, and shale beds. Siltstone beds are gray in color. Claystone and mudstone are brown and gray-colored, while shale is gray or black-colored. The siltstone, mudstone, and claystone contain rootlets, iron concretions, plant fossils, and plant debris in some places. Internal stratification may exhibit planar, horizontal, interlaminated siltstone, mudstone and/-or claystone beds with sharp, horizontal bedding planes. Stratification may also be contorted by soft-sediment deformation. The shale is platy to friable in places. Beds thicknesses range from $\sim 0.20-5 \mathrm{~m}$. Beds can extend laterally from $\sim 2->100 \mathrm{~m}$. The siltstone, mudstone, and claystone beds are interpreted as suspended load sediments deposited by waning flow. The interbedded siltstone, mudstone, and claystone facies were deposited within channels with waning flow, and in the floodplain, as indicated by bedding continuity.

\subsubsection{Massive Siltstone or Claystone (Fm)}

This facies is characterized by structureless siltstone, claystone, and mudstone up to $\sim 0.15$ $\mathrm{m}$ thick. Siltstones are gray in color. Mudstone and claystone are gray or brown-colored. This facies lacks clear internal stratification, laminae or beds. The siltstone, mudstone, and claystone beds are mostly planar and horizontal with sharp, horizontal bedding planes. The mudstones and claystone beds may occur as lenticular beds with sharp, trough-shaped bedding planes. The planar-bedded siltstone, mudstone or claystone are laterally discontinuous, extending laterally for $\sim 0.10->10 \mathrm{~m}$, and have thickness ranges from 0.05 to $0.15 \mathrm{~m}$. The lenticular mudstone or claystone may be up to $0.10 \mathrm{~m}$ thick and extends laterally up to $\sim 0.10 \mathrm{~m}$. The massive siltstone or claystone is suspended load deposited by standing floodwaters or low energy channel flow. This facies was interpreted to have been deposited within the channel during the abandonment of the channel, or in floodplain or swamp as underclay deposits.

\subsubsection{Coal (C)}

Coal beds are characterized by blocky, dull coal beds with clay to silt-sized partings in most places. The coal beds are up to $0.50 \mathrm{~m}$ thick, laterally discontinuous and have planar or lenticular geometry, with a horizontal bedding plane. Some coal beds contain fossilized 
Calamites trunks. The coals were interpreted as to have been deposited during high water levels and low sediment supply most likely in a vegetated swamp or floodplain. 


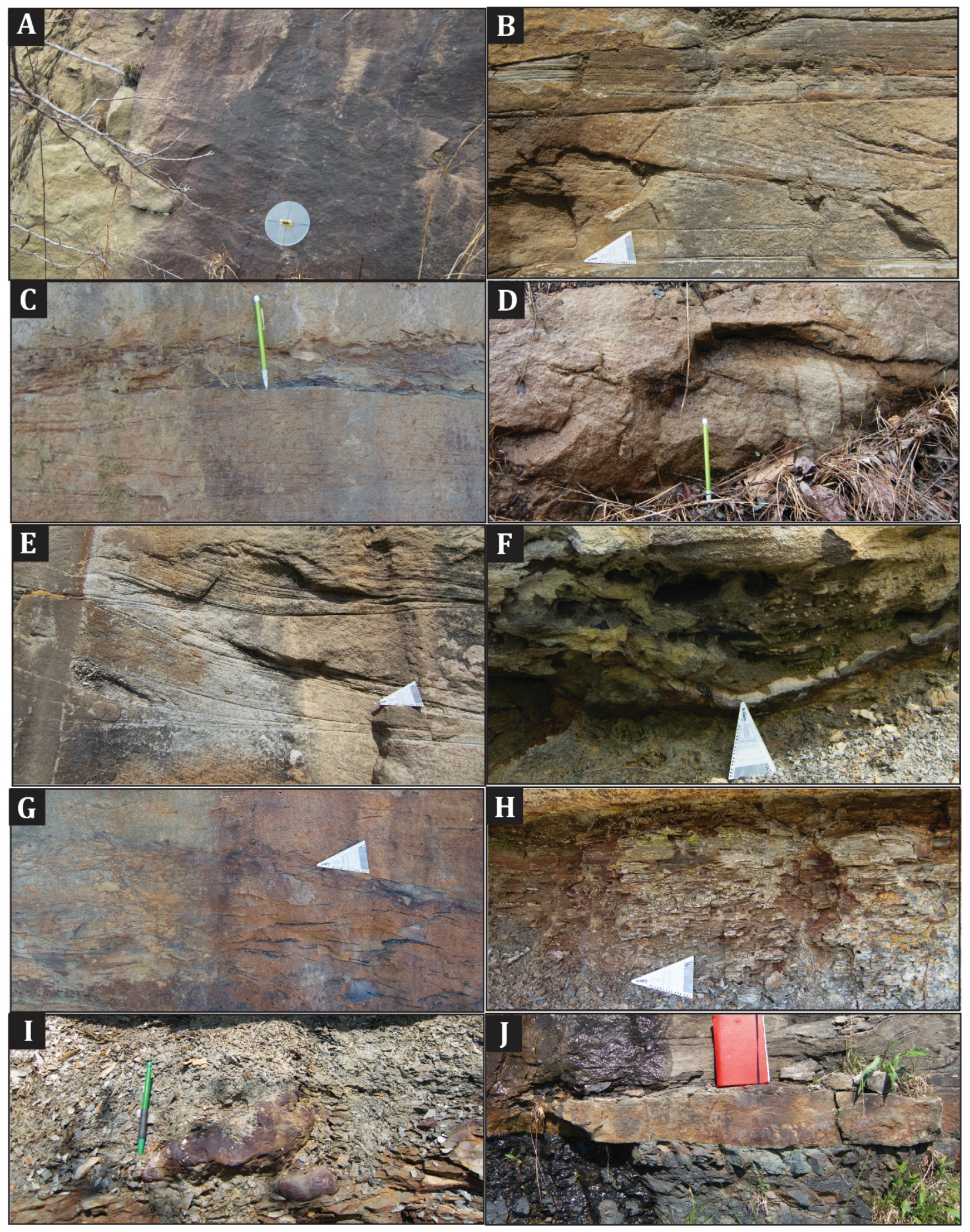


Figure 1-4: Lithofacies of lower Middle Pennsylvanian Allegheny Formation. A) Massive sandstone ( $\mathrm{Sm}$ facies). Diameter of circular level is $10 \mathrm{~cm}$ for scale B) Planar-stratified sandstone (Sh facies). Long side of triangular ruler is $11 \mathrm{~cm}$ for scale. C) Low angle crossstratified sandstone (S1 facies). Pencil length is $15 \mathrm{~cm}$ for scale. D) Planar cross-stratified sandstone (Sp facies). Pencil length is $15 \mathrm{~cm}$ for scale. E) Trough cross-stratified sandstone (St facies). Long side of triangular ruler is $11 \mathrm{~cm}$ for scale. F) Poorly sorted conglomerate and sandstone (Ss facies). Long side of triangular ruler is $11 \mathrm{~cm}$ for scale. G) Ripple bedded sandstone ( $\mathrm{Sr}$ facies). Long side of triangular ruler is $11 \mathrm{~cm}$ for scale. $\mathrm{H}$ ) Interlaminated siltstone and mudrock (Fl facies). Long side of triangular ruler is $11 \mathrm{~cm}$ for scale. I) Massive mudrock (Facies Fm). Pencil length is $15 \mathrm{~cm}$ for scale. J) Coal bed (C facies). Field note length is $25 \mathrm{~cm}$ for scale. 

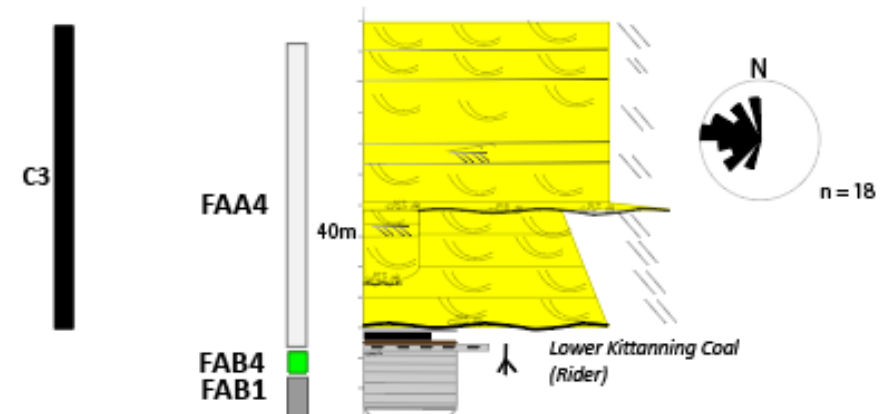

1
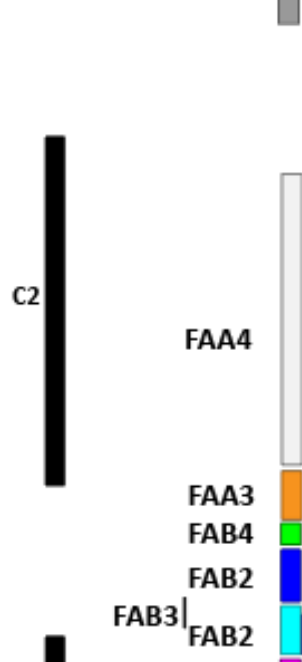

†

FAA2

$20 \mathrm{~m}$ int

ina

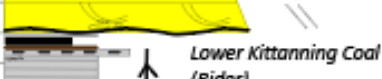

$\longrightarrow$

m -

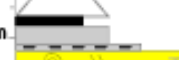

Covered section

Lower Kittonning Cool
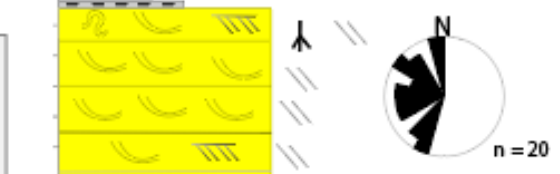

$n=20$

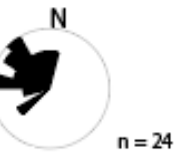

$n=24$
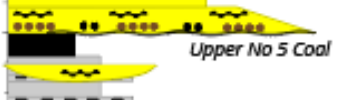

$\overline{z \Sigma}=$

iㅔ

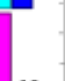

$10 \mathrm{~m}$

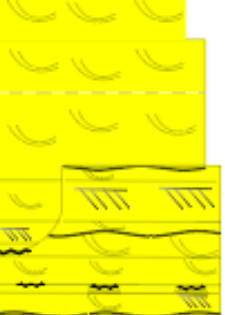

FAA1

FAB4

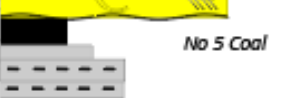

Mud sitt VF F M C WC Petblo

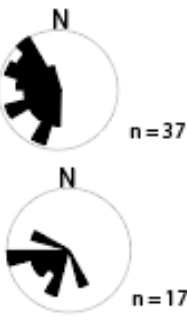

Lithofacies

$\mathrm{Sp}, \mathrm{St}, \mathrm{Sm}$

\section{Facies Association}

$\mathrm{Sp}, \mathrm{Sm}$

$\mathrm{C}=$ Channel belt complex

FAA1 = Facies Association A1

$\mathrm{C}, \mathrm{Fl}, \mathrm{Fc}$

FAA2 = Facies Association A2

FAA3 = Facies Association A3

FAA4 = Facies Association A4

FAB1 = Facies Association B1

$\mathrm{Ss}, \mathrm{Sr}, \mathrm{Sp}, \mathrm{Sm}, \mathrm{Sl}$, rare truncated $\mathrm{St}$,

FAB2 = Facies Association B2

FAB3 $=$ Facies Association B3

FAB4 $=$ Facies Association B4
C, FI

$\mathrm{Sh}, \mathrm{Sr}, \mathrm{Sp}, \mathrm{Sm}, \mathrm{FI}$

$\mathrm{Sh}, \mathrm{Sr}, \mathrm{Sp}, \mathrm{St}, \mathrm{Sm}$

$\mathrm{Sh}, \mathrm{Sr}, \mathrm{Sp}, \mathrm{St}, \mathrm{Sm}$,

$\mathrm{Fl}$

$\mathrm{C}, \mathrm{FI}$

Key

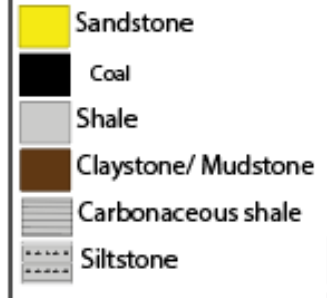

..... Coal clast

Rip-up clast

000 Siderite/ Ironstone nodules

Trough cross stratification

Convex upwards sheets

Low angle cross

stratification

Planar cross stratification

$-$

Inclined beds

Deformed bed

1. Root features

Plant fossil/ trash (branches,

leaf etc)

Paleocurrent direction

Figure 1-5: Composite stratigraphic column of the lower Middle Pennsylvanian Allegheny Formation study interval at Birch River, West Virginia with interpreted facies, facies association and paleocurrent direction. Modified from Abatan and Weislogel (2020). 


\section{FA Lithofacies Description \\ Geometry \& Architectural elements. \\ Interpretation}

\section{A = Fluvial Channel deposits}

A1 Sh, Sr, S1, Planar bedding, horizontal lamination, $\mathrm{Sm}, \mathrm{Fl}$, rare planar and trough cross-bedding, massive $\mathrm{Sp}$ sandstone, contorted bedding, current

A2 Sh, Sr, Sp, Fl

A3 Sl, Sh, Sm, $\mathrm{Sr}$

A4 St, Sp, Sh, $\mathrm{Sr}, \mathrm{Ss}, \mathrm{Sm}$

\section{Planar bed with convex upward basal} contacts, horizontal lamination, and low angle cross-bedding

\section{Inclined tabular beds with planar and} trough cross-bedding, and ripple crosslamination ripple lamination, interbedded silt, and mud

Tabular sandstone body (TSB), lensshaped sandstone body (LSB), downstream accretion (DA), tabular, interbedded or interlaminated siltstone and mudstone (FF), nested channels (NC), rare sheet sandstone body (SSB)

Sheet sandstone body (SSB) and rare nested channels (NC). sandstone with trough cross-lamination, planar cross-lamination, and horizontal cross-stratification
Low-sinuosity fluvial

channel
Unclear macroform element in upper sections. TSB in the lower section.

Upper flow regime flow fluvial channel

Inclined lateral accretion sandstone beds (LA) and LSB

Sinuous fluvial channel
Braided plain/ channel 
B = Non-Fluvial Channel Deposits

B1 Sr, Fm, Fl, C Planar beds with current ripple, planar lamination and up to $20 \mathrm{~cm}$ thick discontinuous massive mudstone

B2 Fl, Sr, Sp Continuous current ripple lamination

B3 Fl, Sr, Sp

Planar beds with bidirectional planar cross-lamination, horizontal planar lamination, and current ripple lamination
Extensive sheets and lenticular bodies of FF

Continuous tabular interbeds of siltstone, mudstone and sandstone (FS).

FS and FF overlain by SSB and massive Lacustrine delta. TSB (Coarsening upwards)

Poorly drained floodplain. splay.
Well drained flood plain and crevasse

Coal beds
FF
Swamp

B4 C, Fm 


\section{Facies Association}

Facies association analysis revealed stratal architectures which aided the interpretation of fluvial channel morphology of 3 channel belt complexes and associated non-channel subenvironments of the MPAF depositional system (e.g., Bridge, 2009; Miall, 2014, 1996). Facies associations are categorized herein into either fluvial channel fills or non-fluvial channel associations, which includes floodplain overbank, lacustrine delta, floodplain lacustrine, and mire/ swamp. Table 1-2 describes the facies associations including their lithologies, geometry, architectural elements, and fluvial styles.

\subsection{Fluvial Channel Deposits: Facies Association A}

The sandstone deposits of the MPAF are separated by coal beds and associated mudrock deposits. Facies architectural analysis showed that their 3 channel belts complexes at the study location. The channel belts are characterized by multiple storied channels that exhibit different Facies associations. Channel belt complex 1 (C1) exhibit Facies association A1 and Facies association A2, Channel belt complex 2 (C2) exhibit Facies association A3 and A4, and Channel belt complex 3 (C3) exhibit Facies association A4.

\subsubsection{Facies Association A1: Low-sinuosity fluvial channel deposits}

\subsubsection{Description}

Facies association A1 (FA A1) is characterized by multiple stories of laterally continuous, fine to coarse-grained, tabular or lenticular, medium-bedded sandstone. Multistory complexes are up to $10 \mathrm{~m}$ thick and exhibit sharp and undulating erosional basal contacts (Fig. 1-6). Individual stories are up to $4 \mathrm{~m}$ thick and characterized by erosionally truncated, 0.25 to $1 \mathrm{~m}$ thick sandstone beds at the base, overlying sharp, sub-horizontal to trough-shaped, undulating, erosional surfaces that can be traced for $18-495 \mathrm{~m}$. Deposits of siltstone, mudstone (Fl) and massive claystone deposits (Fm) sometimes separate some of the stories. The FA A1 sandstone bodies form well-defined internal architectural elements, such as sandstone bed-set macroforms with convex-upward lenticular geometry; however, some sandstone bed-sets macroforms exhibit tabular geometry.

FA A1 stories are characterized by abundant trough cross-bedded, fine to medium-grained sandstone beds ( $\mathrm{St}$ ) that range in thickness from $0.1 \mathrm{~m}$ to $0.50 \mathrm{~m}$ average thickness $<0.5 \mathrm{~m}$ ). The upper stories of FA A1 are characterized by planar cross-bedded, fine to medium-grained, sandstone (Sp) tabular bed-sets with thickness ranging from $0.7-1 \mathrm{~m}$, whereas lower stories are characterized by trough cross-bedded, fine to coarse-grained sandstone ( $\mathrm{St}$ ) lenticular bed-sets with thickness ranging from $0.10-0.25 \mathrm{~m}$. Individual FA A1 stories are made up of $0.25-0.50$ $\mathrm{m}$ thick tabular or lenticular, horizontal beds of poorly sorted, medium-coarse grained, sandstone (Ss) overlain by up to $0.20 \mathrm{~cm}$ thick horizontal beds of horizontally laminated, fine to mediumgrained sandstone (Sh). Where Sh is absent, Ss may be overlain by $0.10-1 \mathrm{~m}$ thick, medium to fine-grained, Sm, St or Sp sandstone beds. Where Sh is present, it is overlain by $>0.05 \mathrm{~m}$ thick, ripple laminated sandstone ( $\mathrm{Sr}$ ) with pebble-sized siderite nodule concretions. The $\mathrm{Sr}$ is overlain by $0.10-1 \mathrm{~m}$ thick beds of either Sm, St, or Sp. Laterally discontinuous, trough-shaped bed-sets of fine-grained ripple laminated sandstone $(\mathrm{Sr})$ interbedded with siltstone and mudstone (Fl) and 
massive claystone lenses (Fm) represent mud-drapes or abandoned channels. These overlie beds of Sm, St or Sp that comprise uppermost FA A1 stories and are absent within younger FA A1 stories. Paleocurrent directions measured from trough cross-beds indicate a paleoflow was towards the west-southwest (Fig. 1-5).

FA A1 architectural elements comprise deposits of channel belt complex 1 (C1). The basal channel stories contain downstream accretion (DA) elements up to $1 \mathrm{~m}$, which laterally and vertically transition into $\sim 1 \mathrm{~m}$ thick, lens-shaped sandstone bodies (LSB). The DA elements characterized by stacked horizontal laminated (Sh), trough cross-bedded (St), planar trough cross-bedded ( $\mathrm{Sp}$ ) and ripple-laminated bed-sets, which represent the most abundant architectural elements observed in the sand bodies of FA A1. The LSB is characterized by multiple, stacked beds of horizontal planar laminated (Sh), ripple laminated (Sr) massive and/ or trough cross-bedded $(\mathrm{St})$ sandstone bounded above and below by trough-shaped bedding planes. The LSB - DA are typically overlain by up to $2 \mathrm{~m}$ thick, tabular shaped sand bodies (TSB). The TSB are characterized by single or multiple beds of massive $(\mathrm{Sm})$, trough cross-stratified (St), or/and planar cross-stratified ( $\mathrm{Sp}$ ) sandstone with a horizontal bedding plane. The LSB-DA elements may also be overlain by sheets of interlaminated siltstone and claystone (F1). Compound elements containing DA, LSB and TSB are truncated and separated by erosional surfaces in most places. All the cross-beds of FA A1 are dipping to the north.

\subsubsection{Interpretation}

The abundance of LSB-DA and TSB channel fill architectural elements suggests that FA A1 formed from a low-sinuosity fluvial depositional system (Allen et al., 2014; Bridge, 2009; Gibling, 2006; Miall, 1996). The abundance of trough cross-bedded sandstone suggests that 3D dunes were the most dominant bedform within the fluvial channel (Miall, 1996). The lenticular LSB-DA elements overlain by TSB elements with tabular geometry, suggests a transition from sediment accumulation in channels with lower lateral mobility to sediment accumulation in channels with greater lateral mobility, that deposited sediment across a broad alluvial plain (Allen et al., 2014; Gibling, 2006). The extensive erosional surfaces between sand bodies suggest repeated episodes of widespread channel erosion and down-cutting followed by aggradation. This is further supported by truncation of sand bodies by erosional surfaces and the inclusion of coal intraclast, which suggests that the channel had substantial, system-wide erosive power. Cyclic deposition of upper flow regime facies (Sh) that grades upward into lower flow regime facies (St, Sp, and Sr facies), suggest a perennial fluvial system with fluctuating flow regime and sediment flux (Allen et al., 2014; Luttrell, 1993; Miall, 1996). The increase in Sp thickness in younger, upper FA A1 sandstone beds indicates an increase in flow depth with time. Preserved claystone plug $(\mathrm{Fm})$ within channel stories suggest there were instances of channel abandonment (Allen, 1970; Catuneanu, 2006; Miall, 2014, 1996). Flow depth estimated from cross-set thicknesses of the low sinuosity channel (FA A1) ranged from $7-11 \mathrm{~m}$. Together, these attributes indicate deposition in a perennial fluvial system (Allen et al., 2014; Bridge, 2009; Gibling, 2006; Miall, 1996). 

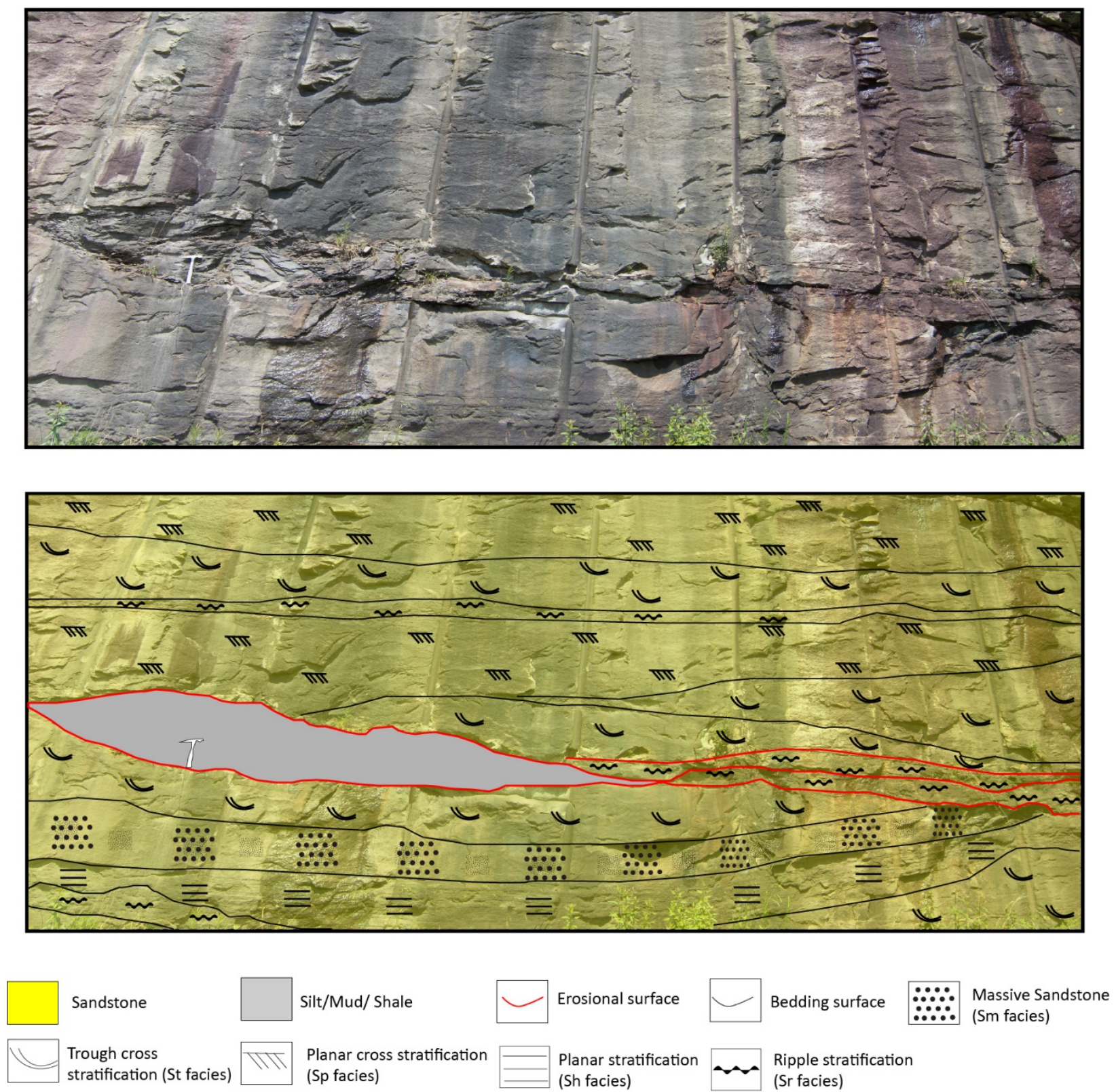

Figure 1-6: Typical facies association A1 outcrop and interpretation of lithofacies and facies association. Hammer is $28 \mathrm{~cm}$ long.

\subsubsection{Facies Association A2: Braided fluvial deposits}

\subsubsection{Description}

The basal sand-body of Facies association A2 (FA A2) overlies FA A1 (Fig. 1-7). FA A2 is made up of up to $5 \mathrm{~m}$ thick, multi-storey, amalgamated, fine- to coarse-grained sandstone beds with sharp, undulating, near-horizontal or channelized, erosional bounding surface (Fig. 1-7). Individual FA A2 stories are about $1-2 \mathrm{~m}$ thick and are composed of multiple sets of $0.10-$ 
$0.30 \mathrm{~m}$ thick tabular or lenticular, medium-grained, trough cross-bedded sandstone beds sporadically capped by $<0.10 \mathrm{~m}$ thick siltstone beds (Fl). The lateral extent of individual stories is difficult to discern from the outcrop due to the amalgamated nature of the bedding planes. The lower bounding surfaces of individual stories are sharp, near horizontal, lenticular or channelized, and overlain by siderite pebble lags in some places. The upper bounding surface of FA A2 is erosionally-truncated and overlain by either laterally extensive ripple-laminated sandstone ( $\mathrm{Sr}$ ), siltstone (Fl), and mudstone bodies (Fl) within Facies association B2, or heterolithic coarsening-upward sandstone beds of Facies association B3, which are described and interpreted below as deposits of a well-drained flood plain and lacustrine delta, respectively.

FA A2 deposits are characterized by poorly to moderately well-sorted, fine to coarsegrained, trough cross-bedded ( $\mathrm{St}$ ), ripple laminated ( $\mathrm{Sr}$ ) and planar-bedded ( $\mathrm{Sh}$ ) sandstone beds with sharp, undulating, near-horizontal or lenticular amalgamated surfaces. The trough crossbedded sandstone deposits are the most common bedforms observed in FA-A2. Basal sandstone beds of FA A2 contain very coarse sand and pebble lags (Ss facies) locally, but most beds are composed of medium-grained sandstone. The basal sand bodies are characterized by $0.10-0.30$ $\mathrm{m}$ thick, horizontal or slightly inclined, amalgamated, medium to very coarse-grained sandstone with pebble-sized quartz clast, trough cross-bedded sandstone ( $\mathrm{St}$ ). The $\mathrm{St}$ may be overlain by $<0.10 \mathrm{~m}$ thick beds of ripple laminated sandstone ( $\mathrm{Sr}$ ) with coal intraclast in the lower parts; $\mathrm{Sr}$ facies are generally lacking in the upper parts of FA A2. The Sr beds sometimes grade laterally and vertically into planar bedded sandstone (Sh) with a thickness range of $0.10-0.30 \mathrm{~m}$. The upper sand bodies of FA A2 are characterized by multiple beds of $0.10-0.30 \mathrm{~m}$ thick, planar or lenticular, amalgamated, cross-bedded sandstone ( $\mathrm{St}$ ) or massive sandstone beds $(\mathrm{Sm})$ with sharp undulating bedding planes. Individual stories show normal grading of fine to coarse-grained sandstone bed sets. Paleocurrent directions derived from trough cross-beds indicate paleoflow was towards northwest.

FA A2 architectural elements are made up of mainly sheet sandstone bodies (SSB), and rare nested channel (NC) (Fig. 1-7). The SSB are made up of horizontal or slightly inclined, tabular to lenticular, sandstone beds bounded above and below by sharp, undulating, nearhorizontal erosional surfaces. The near horizontal erosional surfaces extend laterally for $\sim 10 \mathrm{~m}$. Individual SSB are dominated by amalgamated trough cross-bedded sandstone beds up to $\sim 2 \mathrm{~m}$ thick. SSB may be capped by fine-grained sandstone in some places. The SSB of lower stories are capped by siltstone (Fl). Individual FA A2 stories are characterized by multiple sets of SSB elements that are bounded above and below by erosional surfaces. The SSB of upper stories lacks interbedded fine-grained deposits. The NC elements are characterized by nested, planar or lenticular, St, Sm and Sr sandstone beds with a common channelized erosional bases. The channelized erosional surface extends laterally for $\sim 15 \mathrm{~m}$. The sandstone beds of NC elements bounded above by near-horizontal or trough-shaped erosional surfaces.

\subsubsection{Interpretation}

The abundance of trough cross-bedded sandstone in FA A2, and the absence of inclined or lenticular macroforms, which are common in downstream or lateral accreting sandstone bodies in FA A2, suggests that FA A2 formed from a low-sinuosity, braided fluvial depositional system (Allen et al., 2014; Flood and Hampson, 2014; Medici et al., 2015). The abundance of $\sim<0.25 \mathrm{~m}$ 
thick, tabular, and lenticular trough-cross stratified sandstone beds suggest deposition by a perennial fluvial system. The braided channel flow depth, which were estimated from cross-set thicknesses ranged from 4-7 m (Leclair and Bridge, 2001). The abundance of amalgamated trough cross-bedded sandstone (St) in the sand bodies of FA A2 indicates the fluvial system was dominated by 3D dunes; FA A2, however, lacks the DA elements and meter scale Sp which are beds observed in FA A1 deposits. The Sh was deposited by upper flow regime currents, while $\mathrm{Sr}$, Sp, and St were deposited by lower flow regime currents (Allen, 1979, 1970; Luttrell, 1993; Miall, 1996). Beds of Sp and St are deposited in the deepest part of a flat-floored channel, whereas $\mathrm{Sr}$ is deposited on larger bedforms or channel bars. The abundance of the St and $\mathrm{Sp}$ indicates sediments were deposited mainly on the channel floor of this fluvial system. The rarity of interbedded siltstone in the upper SSB element may be due to sediment reworking, which reduces the preservation of fine-grained overbank facies.
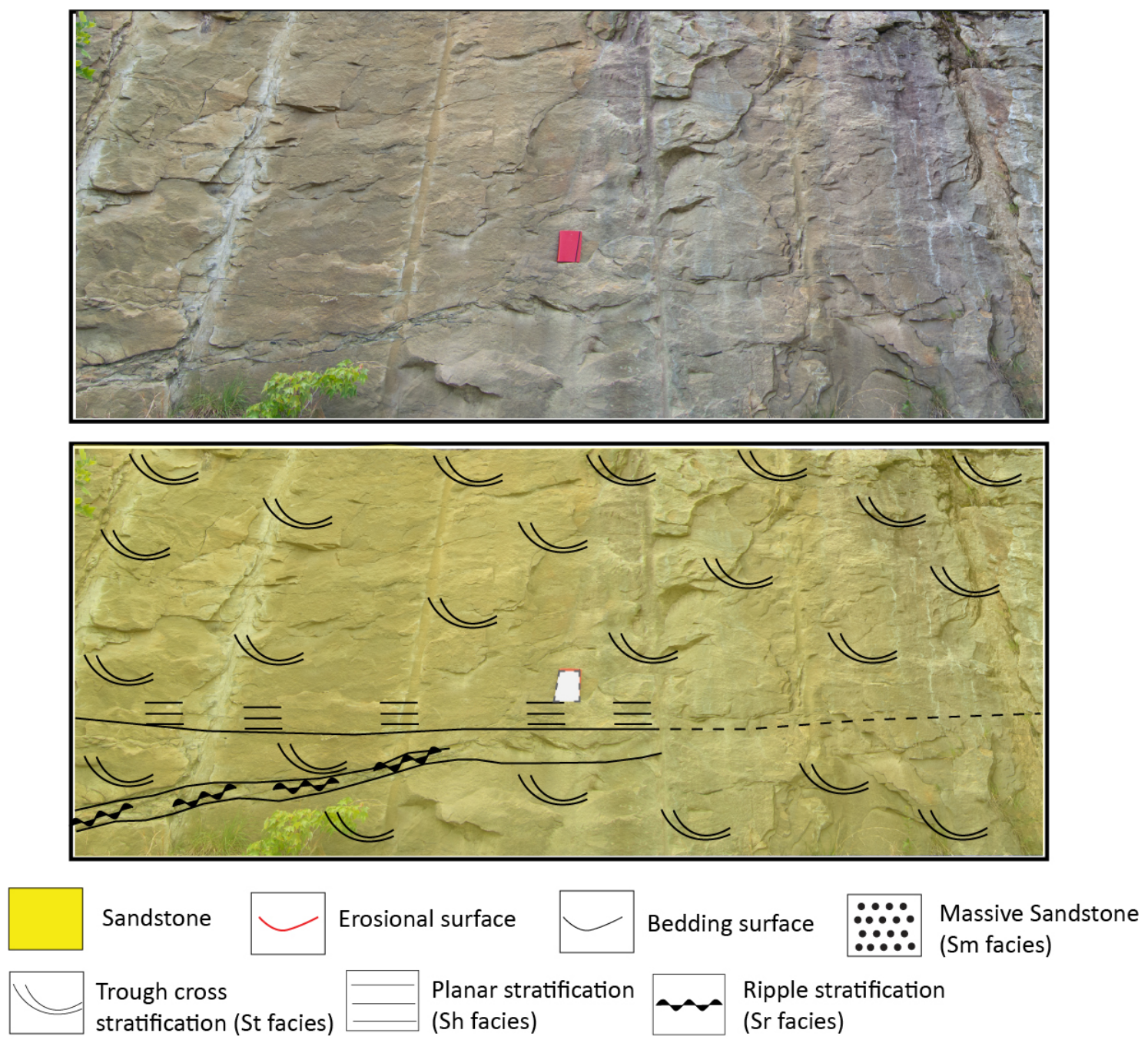
Figure 1-7: Typical facies association A2 outcrop and interpretation of lithofacies and facies association. The notebook is $25 \mathrm{~cm}$ long.

\subsubsection{Facies Association A3: Upper flow regime fluvial channel deposits}

\subsubsection{Description}

Facies association A3 (FA A3) overlies either the Upper No. 5 Block coal beds (FA B4), FA B3 or FA B2. A typical exposure of FA A3 is made up of $\sim 8 \mathrm{~m}$ thick, double-story, tabular, and laterally continuous (100's of $\mathrm{m}$ ), poorly to moderately sorted, medium- to very coarsegrained sandstone bodies with sharp and undulating erosional boundaries.

The lower story of FA A3 is characterized by basal, up to $0.50 \mathrm{~m}$ thick, laterally discontinuous, near horizontal, medium- to coarse-grained, trough cross stratified sandstone (St) beds. The St beds transition laterally or vertically into moderately to poorly sorted, interbedded, ripple laminated sandstone $(\mathrm{Sr})$ and poorly sorted sandstone (Ss) that ranges in thickness from $0.10-1 \mathrm{~m}$. The interbedded $\mathrm{Sr}$ and $\mathrm{Ss}$ are stained with iron, have pebble lags at the base and contains pebble-sized coal and ironstone intraclast (Fig. 1-8). The interbedded Sr and SS may be truncated or overlain by moderately sorted, horizontal, medium-grained St beds, with sharp or gradational bedding plane.

The lower story of FA A3 is bounded above and below by sharp, undulating, horizontal erosional surfaces. The interbedded $\mathrm{Sr}$ and Ss are overlain the upper story sandstone body which is characterized by basal, $0.10-0.30 \mathrm{~m}$ thick, moderately sorted, medium-grained, planar crossstratified sandstone (Sp) beds with sharp, planar, erosional lower bedding plane. The Sp abruptly transitions (i.e. no observed upper bedding plane) vertically and laterally to $0.30-1 \mathrm{~m}$ thick, moderately sorted, fine to medium-grained, very low angle cross-bedded sandstone (S1). The S1 abruptly transition vertically into the overlying $0.15-0.40 \mathrm{~m}$ thick, poorly to moderately sorted, fine to medium-grained, planar stratified sandstone (Sh) (Fig. 1-8). The Sh transitions laterally into $0.15-0.20 \mathrm{~m}$ thick, poorly to moderately sorted, fine to coarse-grained, convex upward sand sheet (S1) in some places. Plan view of Sh and Sl reveal parting lineation on the bedding plane. The convex upward sand sheet composed of S1 is overlain by massive sandstone beds $(\mathrm{Sm})$. Paleocurrent data measured from planar tabular and trough cross-bedded sandstone deposits indicates paleoflow was towards the northwest.

FA A3 architectural elements are not easily observable in the upper and lower sand bodies due to the abrupt transitions of facies and lack of common bounding surfaces, such as the bounding surfaces of lateral accretion bar deposits. However, the upper sand body, which is composed of facies produced by lower flow regime bedforms $(\mathrm{Sp})$ and upper flow regime bedforms (Sh and $\mathrm{Sl}$ ) are $2-3 \mathrm{~m}$ thick, and are bounded below by a sharp, undulating, horizontal erosional surface, and above by a sharp, undulating, channelized erosional surface (Fig. 1-8). The lower sand body is made up of co-sets of tabular and wedge-shaped, St and interbedded, $\mathrm{Sr}$ and $\mathrm{Ss}$ beds, up to $1 \mathrm{~m}$ thick which are bounded above and below by sharp, undulating, near horizontal, erosional surfaces. 


\subsubsection{Interpretation}

The presence of Sh, S1, Sr and Ss bedforms of FA A3, and the sharp transitions between the Sp, Sh, and S1 bedforms all suggest FA A3 represents an upper flow regime fluvial channel deposit with intermittent lower and upper flow regime currents. Deposits of the upper flow regime channel (FA A3) indicate flow depth ranged from 3 - $5 \mathrm{~m}$ (Leclair and Bridge, 2001). The absence of sharp bedding planes in the upper sand bodies of FA A3, and the abrupt transition from $\mathrm{Sp}$ to $\mathrm{Sh}$, and $\mathrm{Sh}$ to $\mathrm{Sl}$, may reflect accumulation during a single flooding event characterized by abrupt changes in flow conditions over the duration of a single flow event. The presence of pebble-sized coal, mud and siderite clasts indicates that the FA A3 fluvial system had considerable erosive power and greater competency than indicated by the predominant grain size class. The horizontal erosional surfaces with overlying pebble lag deposits may then represent erosion by strong upper flow regime events such as flash floods (Bridge, 2009; Miall, 1996). 

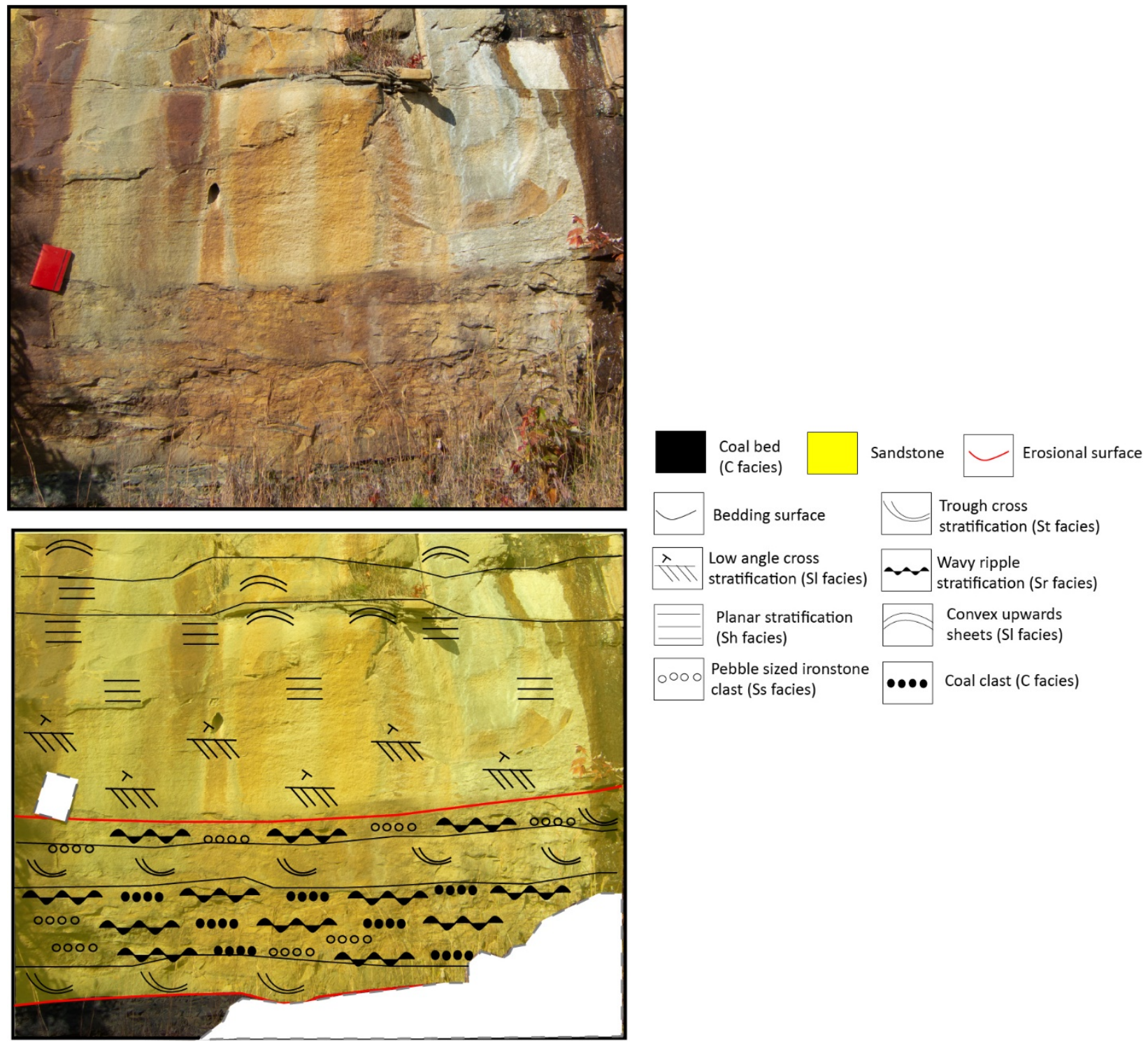

Figure 1-8: Typical facies association A3 outcrop and interpretation of lithofacies and facies association. Notebook is $25 \mathrm{~cm}$ long.

\subsubsection{Facies Association A4: Sinuous fluvial channel deposits}

\subsubsection{Description}

Facies association A4 (FA A4) is characterized by inclined multi-storey, fine to coarsegrained sandstone, with sharp, undulating erosional surfaces that extend laterally across the full $495 \mathrm{~m}$ of the exposed outcrop. Individual stories are up to $8 \mathrm{~m}$ thick and are characterized by inclined tabular or lenticular sandstone capped by very fine-grained sandstone $(\mathrm{Fl})$, siltstone $(\mathrm{Fl})$ or mudstone $(\mathrm{Fl})$. 
The basal sand bodies of FA A4 overlie and truncate FA A3 or other FA A4 multi-story complexes. The basal sandstone of individual FA A4 stories are characterized by $0.30-0.50 \mathrm{~m}$ thick, poorly sorted, lenticular, sandstone and gravel deposits (Ss) with sharp, undulating, channelized, lower erosional surface. The Ss is overlain by moderately sorted, inclined, lenticular or tabular, medium- to coarse-grained trough cross-bedded sandstone (St) beds with sharp bedding planes, that grade laterally into, or are overlain vertically by, moderately sorted, tabular or lenticular, horizontal or inclined, medium to coarse-grained planar cross-stratified ( $\mathrm{Sp}$ ) beds with sharp bedding planes. The thickness of Sp and St ranges from $0.10-0.40 \mathrm{~m}$. The St and Sp bed sets are overlain either by poorly sorted, planar or lenticular, very fine-grained, ripplelaminated sandstone (Sr) or siltstone $(\mathrm{Fl})$ or claystone $(\mathrm{Fl})$. The $\mathrm{Sr}$ or $\mathrm{Fl}$ may be overlain by either an inclined, lenticular or tabular, medium- to coarse-grained, massive sandstone (Sm), St or $\mathrm{Sp}$ beds. Paleocurrent data collected from limbs of trough cross-beds indicate paleoflow was to the northwest.

The FA A4 architectural elements are made up of LA channel fill characterized by $1-5 \mathrm{~m}$ thick inclined, lenticular or tabular, sandstone beds separated by thin (usually $<0.10 \mathrm{~m}$ ) Sr or Fl (Fig. 1-9). Individual stories of FA A4 are characterized by multiple LA elements bounded above and below by sharp, undulating, erosional surfaces.

FA A4 sandstone beds in Channel belt complex 2, which are directly below the Lower Kittanning coal bed (LKC), are deformed by soft-sediment structures and have carbonized plant roots that cross-cut bedding (Fig. 1-10). Deformed sand bodies of FA A4 are characterized by convoluted beds that sometimes intrudes into overlying strata.

\subsubsection{Interpretation}

The abundance of LA elements suggests that FA A4 was deposited by a sinuous fluvial channel. The occurrence of medium to coarse-grained sandstone bodies capped by fine-grained deposits portray a fining-upward sequence common in fluvial deposits (Miall, 1996). The presence of multiple stories with sharp erosional surfaces suggests that the fluvial system was deposited during multiple flooding events, which are common in a perennial fluvial depositional environment (Allen, 1982; Miall, 2014). The channelized, undulating, basal, erosional bounding surfaces observed in FA A4 sand bodies are common in fluvial channels adjusting to gradient variations that occur during periods of low accommodation (Bridge, 2009; Miall, 2014, 1996). The abundance of Sp, St and Sr bedforms indicates deposition by a fluvial system dominated by lower flow regime conditions. The heterolithic nature of FA A4 deposits, characterized by the abundance of fine-grained deposits interbedded with sandstone deposits, implies the fluvial system had a variable flow and sediment flux regime that allowed for such a combination of both mud-rich and sand-rich deposits in the same environment (Bridge, 2009; Luttrell, 1993). The presence of poorly sorted, pebbly sandstone beds at the base of some of the sand bodies of FA A4 suggests that the fluvial stream had considerable power to transport gravel-sized grains (Miall, 1996). The occurrence of petrified plant roots in the upper section indicates the growth of plants subsequent to deposition (Fielding et al., 2009; Plink-Björklund, 2015). The presence of plant roots suggest that water levels were low enough for plants to colonize the channel deposits. The presence of plants within fluvial channels sometimes occur as coping mechanisms due to lack of water for vegetation in seasonal semi-arid climates (Fielding et al., 2009). The deformed 
sandstone beds are convoluted beds formed by soft-sediment deformation (Plink-Björklund, 2015). The folded strata and intrusion of sand into the overlying strata may have been triggered by seismic activities (Allen, 1982; Braccini et al., 2008; Owen and Moretti, 2011). The flow depth of the sinuous channel ranged from $4-8 \mathrm{~m}$ (Leclair and Bridge, 2001).
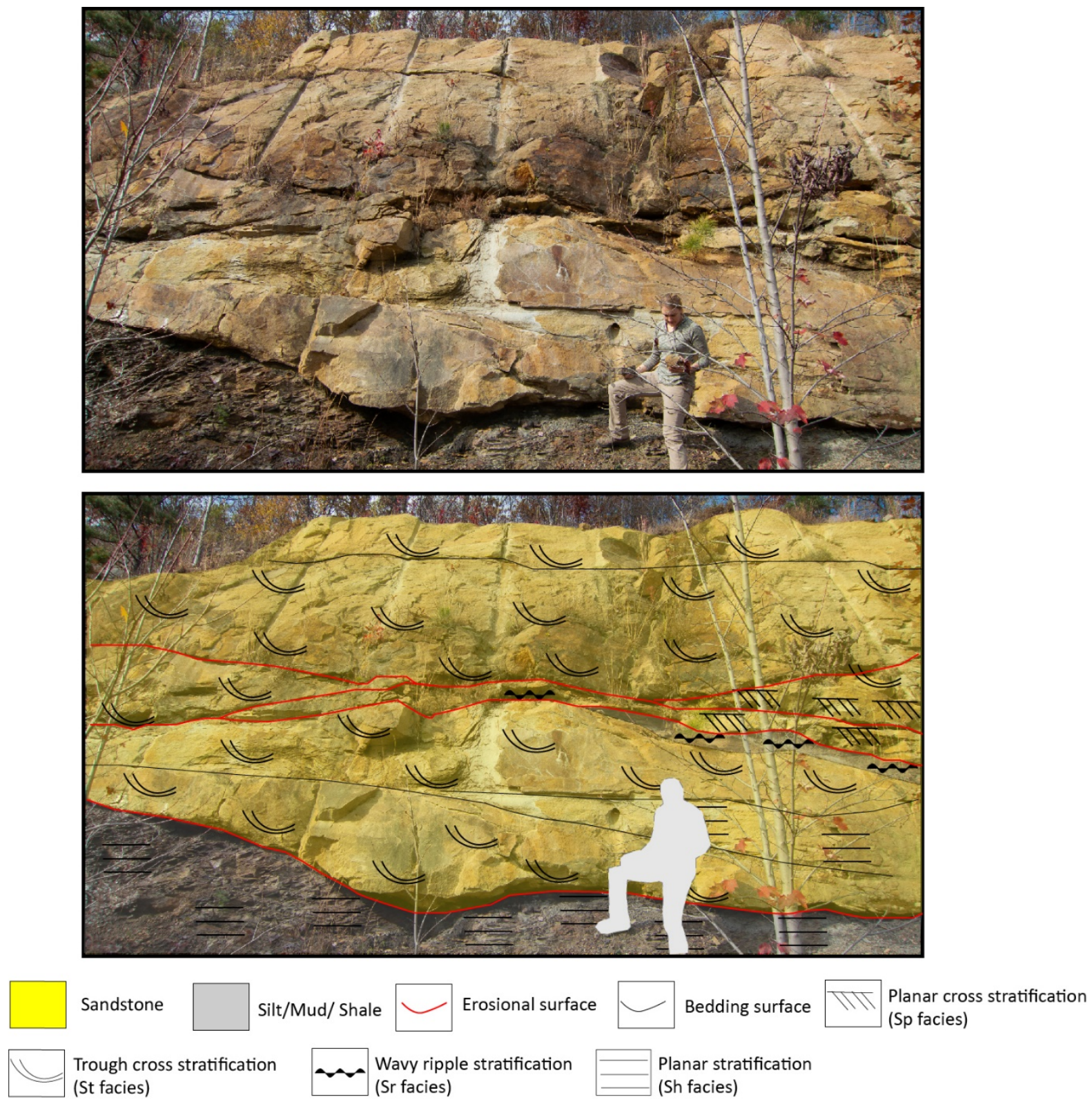

Figure 1-9: A sample exposure of facies association A4 with interpretation of lithofacies and facies association. 


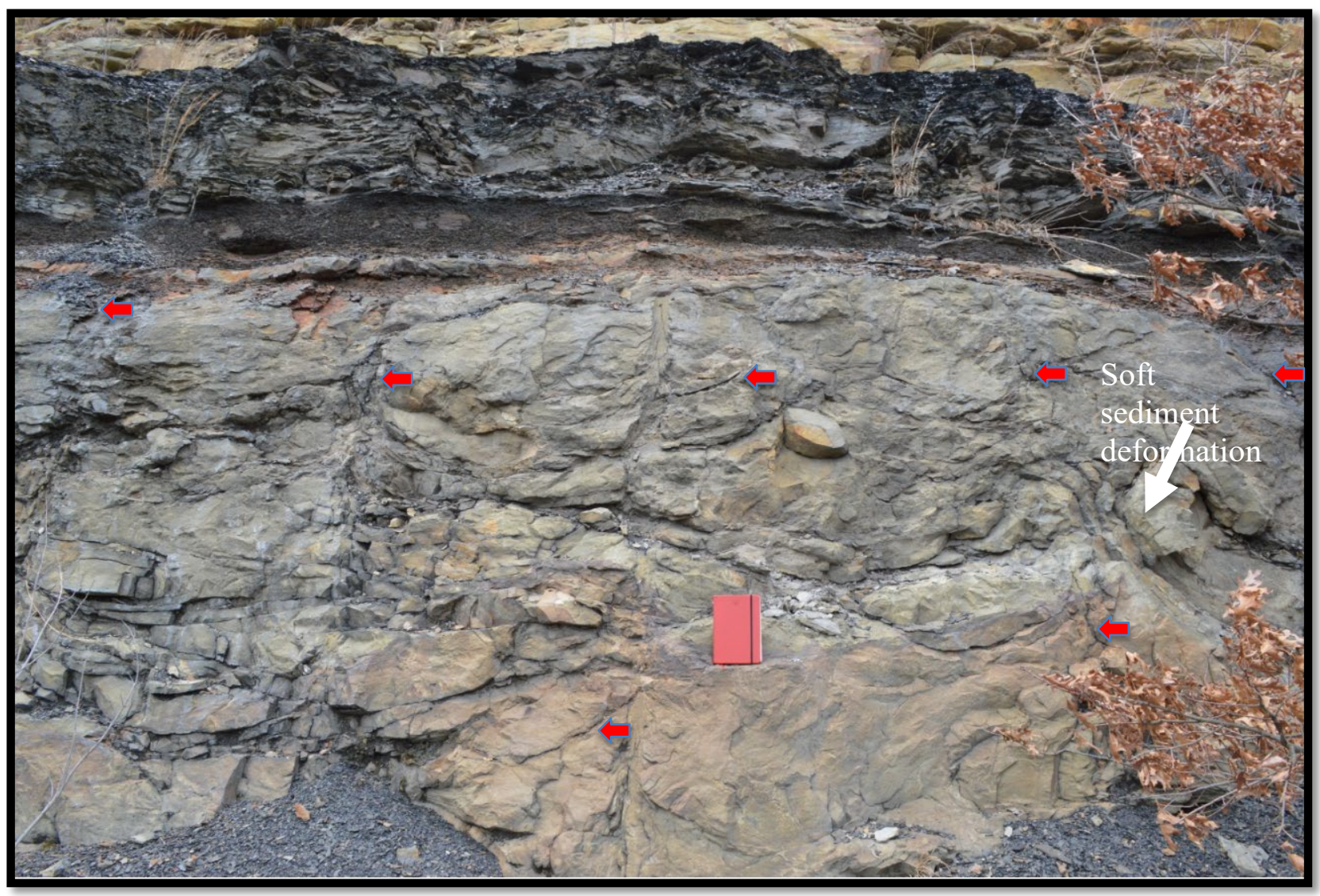

Figure 1-10: Outcrop of facies association B4. Lower Kittanning coal bed overlying deformed sandstone body with soft-sediment deformation caused by water escape (Large white arrow) and carbonized root structures (Small red arrows).

\subsection{Non-fluvial Channel Deposits: Facies Association B}

\subsubsection{Facies Association B1: Poorly-drained floodplain deposits}

\subsubsection{Description}

Facies Association B1 (FA B1) is composed of laminated mudrock (Fl) and massive mudrock (Fm) facies. The Fl beds are up to $1 \mathrm{~m}$ thick with a sharp, horizontal bedding plane. The Fl beds may extend laterally for $\sim 5 \mathrm{~m}$ up to the full length of the outcrop. Where the Fl is associated with Fm, Fm occurs as massive, laterally discontinuous, planar or lenticular, claystone, mudstone or siltstone beds (Fm) overlying Fl beds (Fig. 1-11). FA B1 is overlain by either coal beds or sandstone and overlies sandstone bodies. FA B1 occurs at multiple intervals at the study location and exhibits similar facies succession and planar tabular geometry at all stratigraphic intervals. However, FA B1 is black-colored, friable and carbonaceous where it is associated with Lower Kittanning coal beds, while it occurs as gray-colored, non-friable, noncarbonaceous units where it is associated with the No. 5 Block and Upper No. 5 Block coal beds (Fig. 1-1). 
Architectural elements of FA B1 are characterized by laterally extensive tabular strata that extend the full length of the outcrop and are composed of interlaminated mudrock (claystone, mudstone, and siltstone) (FF) bounded above and below by sharp surfaces and lithologic changes (Fig. 1-11). A typical outcrop exposure of FA B1 is characterized by single or multiple stories up to $4 \mathrm{~m}$ thick of interlaminated shale, siltstone and claystone with a sharp erosional base (Fig. 111). Individual stories are characterized by massive or laminated siltstone at the base, which is overlain by interlaminated shale, mudrock and/ or claystone beds. FA B1 stories may be capped by $<0.5 \mathrm{~m}$ thick, laterally discontinuous massive claystone $(\mathrm{Fm})$.

\subsubsection{Interpretation}

The abundance of fine-grained sediment deposited in near tabular geometry suggests that FA B1 represents sediment deposits that settled out of suspension during waning flow in a poorly-drained floodplain. The lack of coarser-grained deposits suggests that the depositional environment was a low-energy environment, and the carbonaceous sediment suggests deposition in a poorly-drained environment with an elevated water table that is rich in organic material. This together with the overlying coal beds associated with fine-grained deposits of FAB1 indicate that the depositional environment is consistent with a poorly-drained floodplain.

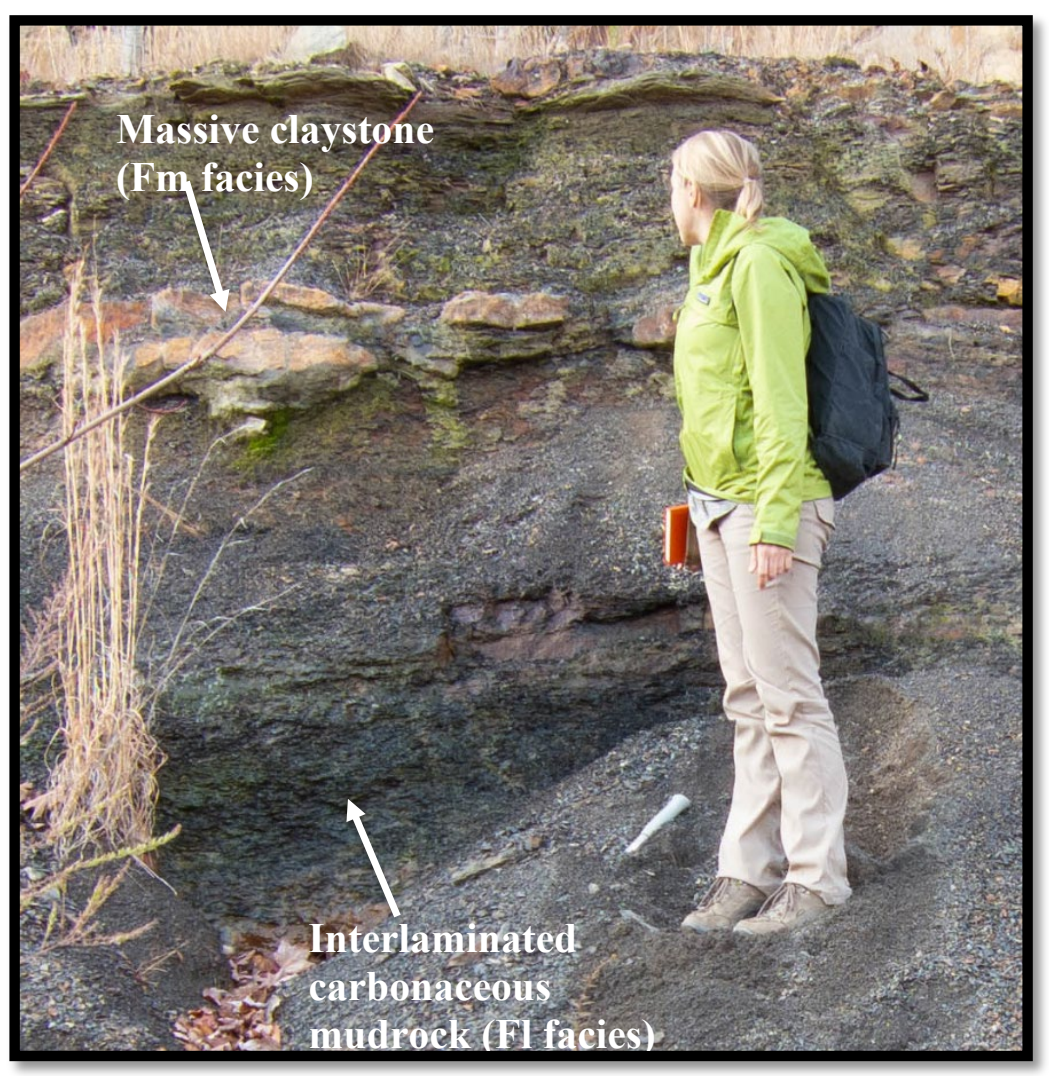

Figure 1-11: Typical outcrop exposure of facies association B1, poorly drained flood plain. 


\subsubsection{Facies Association B2: Well-drained flood plain deposits}

\subsubsection{Description}

FA B2 is made up of interlaminated siltstone and shale beds (F1), and ripple-laminated sandstone (Sr). A typical outcrop exposure of FA B2 is characterized by multiple stories up to $4 \mathrm{~m}$ thick of planar, horizontal sandstone, siltstone, and/ or silty shale beds with sharp, horizontal surfaces (Fig. 1-12). The internal architectural of FA B2 is made up of laterally extensive ( 100 's of $\mathrm{m}$ ), tabular, fine-medium grained, ripple laminated sandstone ( $\mathrm{Sr}$ ) and siltstone sheets (FS) or interlaminated siltstone, silty shale and shale sheets (FF) bounded above and below by sharp, horizontal or trough-shaped bedding planes or erosional surfaces. The beds of Sr and F1 may extend laterally for $\sim 10->100 \mathrm{~m}$, and may be overlain by sandstone deposits. In most FA B2, basal sandy-siltstone deposits (F1) are overlain by interlaminated siltstone, silty shale, and shale beds. The basal siltstone beds have a sharp, horizontal erosional base that truncates underlying sandstone beds, while the upper interlaminated siltstone, silty shale and shale bodies of FA B2 are erosionally truncated. Where ripple-laminated sandstone $(\mathrm{Sr})$ are present, they overlie and sometimes truncate the interlaminated siltstone, silty shale and shale beds (Fig. 1-12). The Sr occurs as fine to medium-grained, sandstone beds with climbing ripples ( $\mathrm{Sr}$ facies). Ripple paleocurrent directions indicate a southeastern paleoflow direction. The Sr also have stigmaria root fossils in them. FA B2 deposits may be overlain by coal or erosionally truncated above. Where Sr beds are erosionally truncated, they are overlain by Ss or St sandstone beds.

\subsubsection{Interpretation}

The occurrence of sandy-siltstone and the abundance of siltstone and interlaminated siltstone and shale with laterally extensive tabular geometry and sharp erosional base suggests Facies association B2 are deposits of well-drained floodplain environment with low energy flow currents. The presence of interlaminated siltstone and shale in the upper section suggest deposition by flow with fluctuating current velocities, resulting in the preferential settling of suspended clay and silt sediments. The presence of fine-grained ripple-laminated sandstone ( $\mathrm{Sr}$ ) beds with climbing ripples overlying finer-grained deposits (siltstone, shale, etc.) suggest deposition by lower flow regime currents in a subaqueous floodplain environment (Bridge, 2009; Miall, 1996). The Sr facies indicate crevasse splay deposition (Makaske et al., 2002; Miall, 1996). 

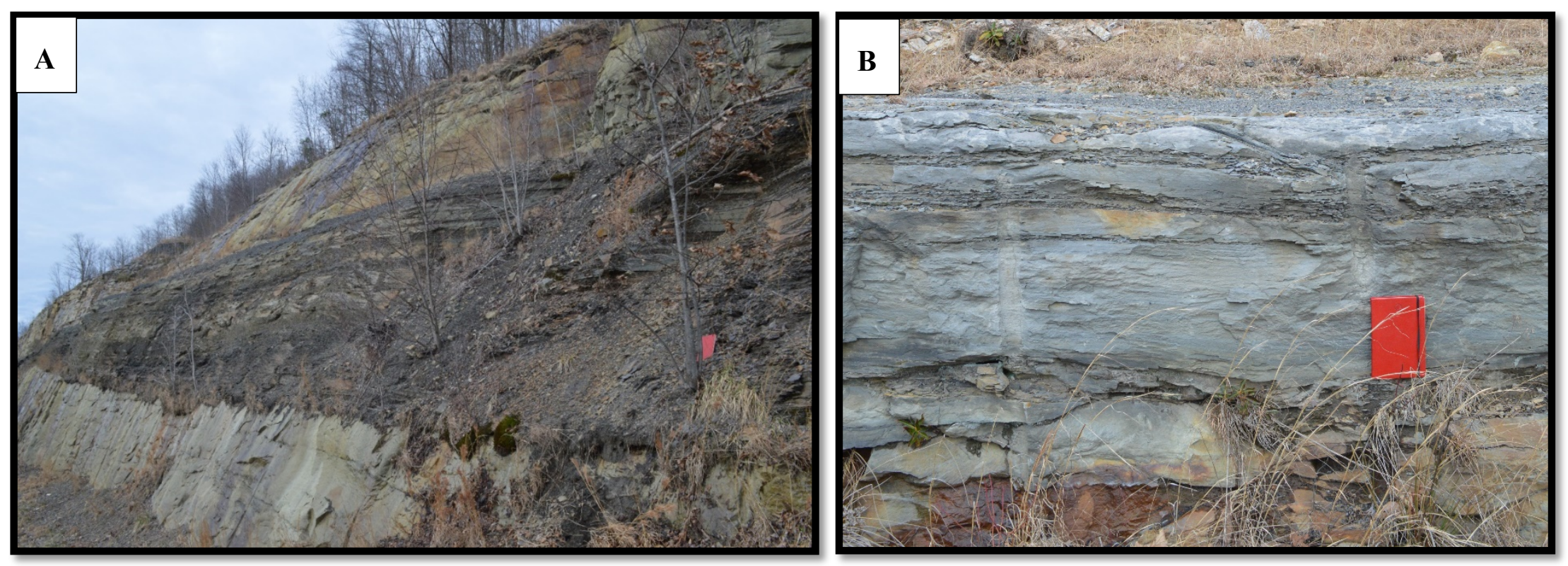

Figure 1-12: Typical outcrop exposure of facies association B2. A) Mudrock deposits of well-drained flood plain overlying channel sandstone. B) Crevasse splay sandstone deposit of facies association B2. Field note is $25 \mathrm{~cm}$ for scale. 


\subsubsection{Facies Association B3: Lacustrine deposits}

\subsubsection{Description}

FA B3 is characterized by a single-story, up to $4 \mathrm{~m}$ thick, coarsening upwards, fine- to medium-grained sandstone (Sp and $\mathrm{Sm}$ ) and interlaminated siltstone and shale (Fl) beds with a sharp, undulating, horizontal or trough-shaped erosional base. FA B3 overlies deposits of FA A2 and is overlain either by FA B2 or Upper No. 5 Block coal beds. FA B3 is bounded above and below by sharp, horizontal or trough-shaped, erosional surfaces. The sandstone (Sp and Sm) and interlaminated siltstone and shale ( $\mathrm{Fl}$ ) beds mostly have a planar tabular geometry which extends laterally for $20->100 \mathrm{~m}$ and range in thickness from $2-10 \mathrm{~m}$. However, a FA B3 sandstone (Sm) bed exhibited a wedge-shaped geometry that is $\sim 2 \mathrm{~m}$ thick and extends laterally for $5 \mathrm{~m}$ locally (Fig. 1-13).

FA B3 is made up of interlaminated, asymmetrical, wavy or planar-laminated siltstone and shale (Fl) that is $\sim 2 \mathrm{~m}$ thick and extends laterally for $20 \mathrm{~m}$. The Fl beds are overlain by up to $2 \mathrm{~m}$ thick, coarsening upward succession of interbedded, planar, horizontal, fine to medium-grained, planar (Sp) cross-stratified sandstone beds with sharp, horizontal bedding planes (Fig. 1-13). The cross-stratification in the Sp beds mostly dip northwards; however, some Sp beds exhibit bidirectional stratification (Fig. 1-13). The Sp beds transition laterally and vertically into massive sandstone $(\mathrm{Sm})$ beds. The Sm may be planar or lenticular, with a gradational bedding plane. The planar Sm beds overlie Sp beds, and they are characterized by fine to medium-grained sand with sharp, horizontal bedding plane. The planar Sm beds are $0.15-0.50 \mathrm{~m}$ thick and extend laterally for $\sim>100 \mathrm{~m}$. The lenticular Sm forms a medium-grained, massive sandstone wedge with a sharp basal erosional surface that overlies either FA A2 deposits or interlaminated, asymmetrical wavy, siltstone, mudstone, and claystone (Fl) beds. The wedge-shaped $\mathrm{Sm}$ is $\sim 2 \mathrm{~m}$ thick and extends laterally for $5 \mathrm{~m}$. The wedged $\mathrm{Sm}$ sandstone is onlapped by up to $4 \mathrm{~m}$ thick, wavy, interlaminated siltstone, mudstone and claystone beds (Fl) with a sharp, channelized, basal erosional surface (Fig. 1-13). The claystone interval of the wavy Fl is lenticular and discontinuous. The wavy, interlaminated siltstone, mudstone, and claystone (Fl) beds extend laterally for $>100 \mathrm{~m}$ and is bounded below by sharp, undulating, channelized erosional surfaces. The wavy Fl beds are erosionally truncated and overlain by FA B2 beds.

FA B3 architecture is made up of tabular, interlaminated siltstone, mudstone and claystone (Fl) overlain by tabular, cross-bedded (Sp) sandstone (FS). The FS bounded above and below by sharp, horizontal surfaces (Fig. 1-13). FS may be overlain by sandstone sheets (SSB), laterally extensive $(>100 \mathrm{~m})$ tabular massive sandstone $(\mathrm{Sm})$ beds (TSB), or lenticular, massive sandstone (Sm) wedge (LSB). The LSB is onlapped by tabular, wavy, interlaminated siltstone, mudstone and claystone $(\mathrm{Fl})$ beds $(\mathrm{FF})$.

\subsubsection{Interpretation}

The tabular geometry and coarsening upwards succession of FS elements suggest they are deposits of a lacustrine deltaic environment. The LSB was interpreted as chute channels or distributary delta channels based on the channelized erosion of LSB into Fl beds. The onlapping of LSB by wavy Fl beds was interpreted as suspended lacustrine deposits onlapping delta bar or distributary channel deposits of a lacustrine delta. The discontinuous massive claystone deposits 
of wavy Fl may have been as a result of flocculation and sedimentation of suspended grains (Allen et al., 2014; Miall, 1996). Grain size and bidirectional planar cross-beds of the lacustrine delta deposits indicate variable flow strength and flow direction. The stratigraphically lower, interlaminated sandstone and mudrock of the lacustrine delta (FA B3) indicate waning flow, while the upper, bidirectional, planar cross-bedded sandstone indicates deposition by bidirectional lower flow regime currents. The laterally continuous, tabular, lacustrine sandstone deposits which are adjacent to, and overlie the deltaic deposit indicate lack of transport because the lake was a basin where sediment settle after being transported and deposited by the delta system.

\subsubsection{Facies Association B4: Swamp/peat mire deposits}

\subsubsection{Description}

Facies association B4 (FA B4) is made up of coal beds (C), ripple bedded sandstone ( $\mathrm{Sr}$ ), laminated mudrock $(\mathrm{Fl})$ and massive mudrock $(\mathrm{Fm})$ facies. A typical exposure of FA B4 is characterized by coal (Fig. 1-14) which may be associated with siltstone, mudstone, and shale with high organic content. The coal beds in the study area have thickness $<2 \mathrm{~m}$. The coal beds are discontinuous and crop out sporadically when traced laterally across the outcrop exposure. The coal beds are overlain by sandstone in most places and the coal beds may be erosionally truncated. Where the coal beds are truncated, they are overlain by sandstone bodies. Where the coal beds are not truncated, they have a sharp contact with the overlying sandstone, shale, or siltstone.

There are three coal beds observed at the study location in stratigraphically ascending order are the No. 5 Block, Upper No. 5, and Lower Kittanning (Blake et al., 2002; Eble, 2002). The No. 5 Block coal beds are overlain by sandstone bodies of FA A1 and they overlie planar interbedded carbonaceous siltstone, shale and claystone strata (Fl and Fm). The bounding surface above and below the coal beds are sharp and may be erosional. The Upper No. 5 Block coal beds partly overlie strata of FA B3 and FA B2. The Upper No. 5 Block coal beds are overlain by ripple dominated sandstone bodies ( $\mathrm{Sr}$ ). The ripple dominated sand bodies are ferruginized and contain pebble lags, rip-up clast, coal rip-ups and siderite/ironstone clast (Fig. 1-8). The Lower Kittanning coal beds are overlain by inclined sandstone deposits of FA A4. The Lower Kittanning coal beds overlie planar interbedded massive discontinuous mudstone, siltstone and carbonaceous shale beds/ lamina (Fl). Lepidodendron and carbonized plant trash fossils were observed in LKC and Upper No.5 Block coal beds.

\subsubsection{Interpretation}

The coal beds are deposits of a swamp/peat mire system. The carbonaceous shale deposits indicate an abundance of organic material deposited in a reducing environment. The associated deposits of coal forming plants and mudrock suggest deposition in a well-vegetated, poorlydrained swamp environment with an elevated groundwater table. 


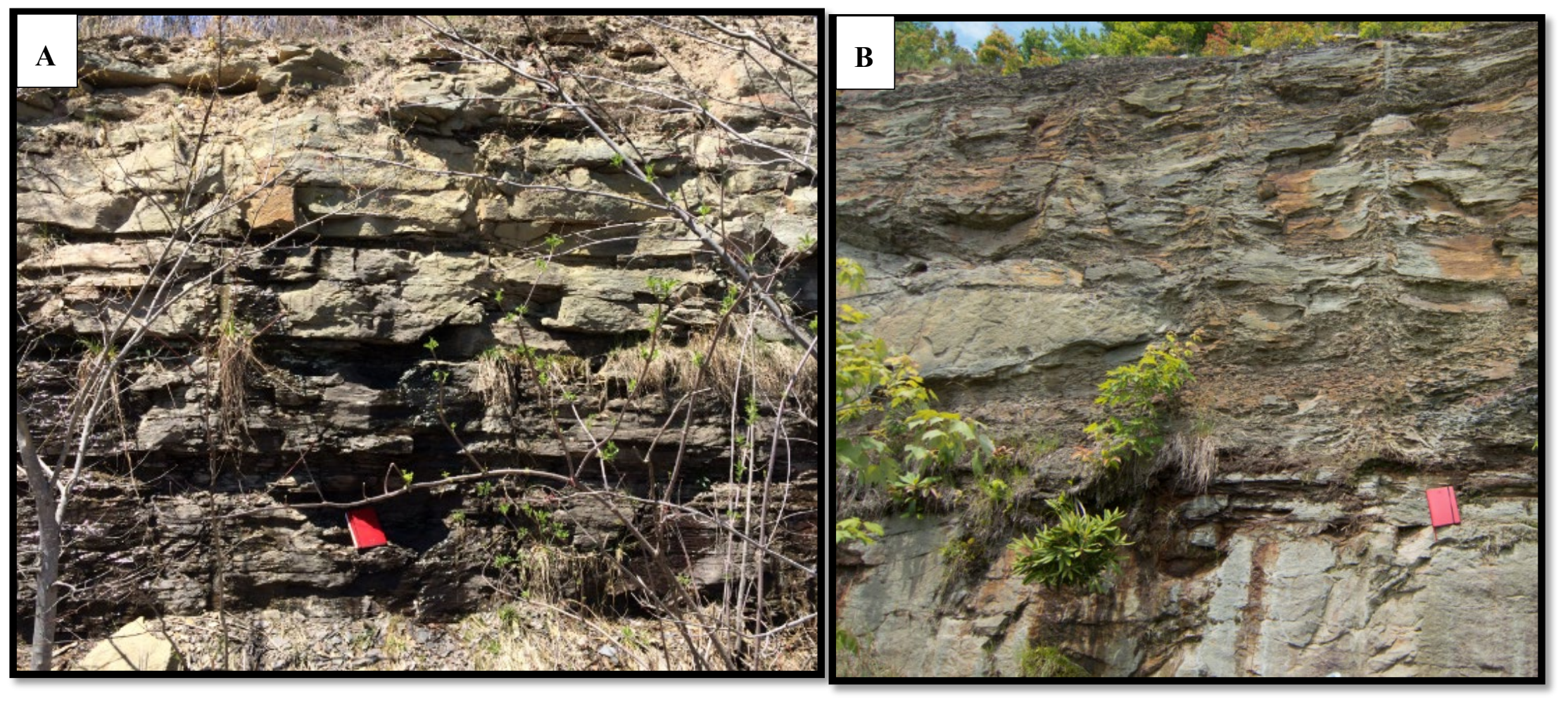

Figure 1-13: Typical outcrop exposure of facies association B3. A) Coarsening upwards deposits of lacustrine delta facies. B) Outcrop exposure of facies association B3, lacustrine delta facies being onlapped by fine-grained deposits interpreted as lacustrine fines. 


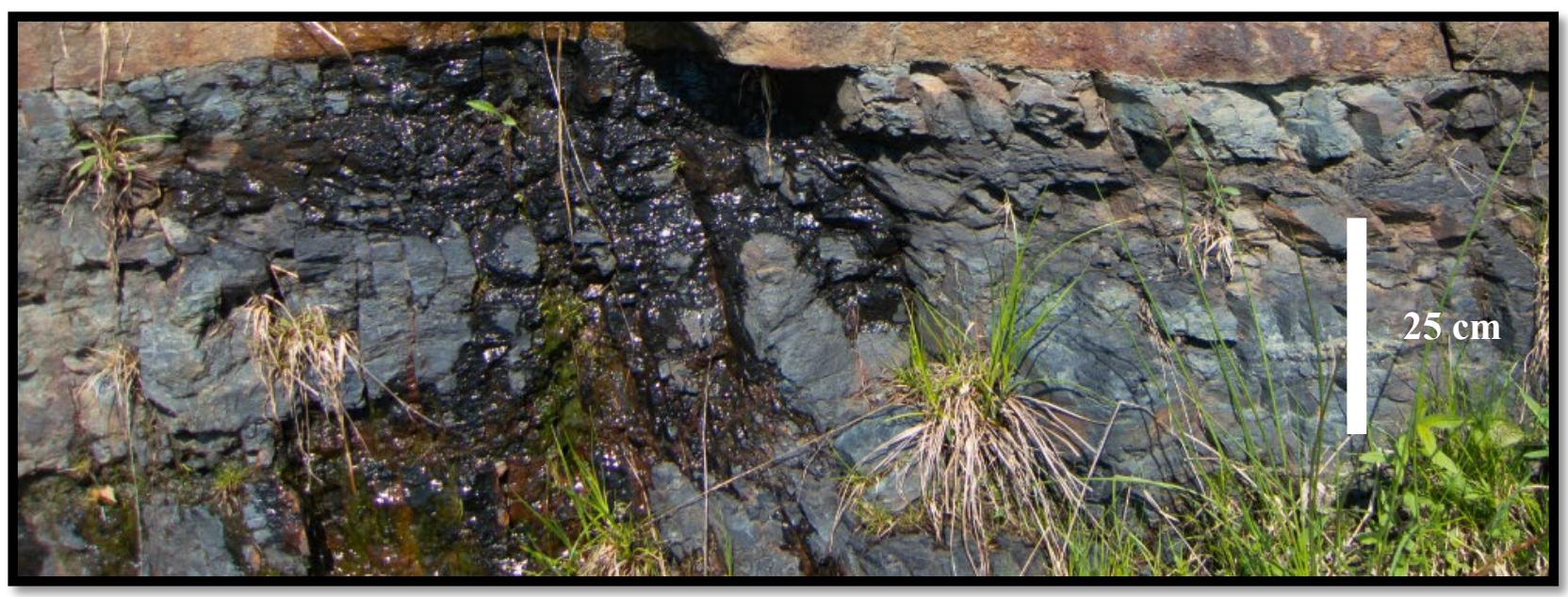

Figure 1-14: Outcrop exposure of facies association B4. No. 5 Block coal bed. The coal bed is below the sandstone bed.

\section{Sediment Transport, Sandstone Composition and Provenance}

Channel bodies of the Middle Pennsylvanian Allegheny Formation (MPAF) in the Birch River area overwhelmingly record sediment transport to the north and northwest (Fig. 1-5). Paleocurrent direction data acquired from cross-bedded facies indicate a generally western to northwestern direction of flow for the paleochannels at the Birch River study location during Middle Pennsylvanian time. One exception is the low-sinuosity fluvial channel (FA A1) with southwest paleoflow directions that indicate sediment transport is towards the west-southwest. However, the braided channel (FA A2), upper flow regime channel (FA A3) and sinuous channel (FA A4) all have northwestern paleoflow directions which indicate sediment transport towards the west-northwest. This indicates a deflection of sediment transport northward over the duration of MPAF deposition. The dominance of moderately sorted, sub-rounded to sub-angular grains suggests that the sediment transport and sorting was efficient.

Modal framework grain composition was determined from 13 sandstone thin-sections from the fluvial channel deposits of the MPAF in order to interpret sediment provenance. Overall, MPAF sandstone deposits are comprised of abundant monocrystalline quartz (Qm), and Qm abundance is similar to the average total quartz $(\mathrm{Qt})$ abundance, indicating little contribution from chert or polycrystalline quartz; however, channel has varying proportions of monocrystalline quartz, polycrystalline quartz, feldspars, lithics and accessory minerals (Table 13). Lithic grains include pseudo-matrix, sedimentary and metamorphic grain fragments. Some of the pseudo-matrix were counted as lithics of indeterminate origin because they were compacted by surrounding grains which lead to difficulty in identifying the internal texture. Sedimentary lithics are mainly siltstones fragments and metamorphic lithics include polycrystalline quartz with aligned muscovite grains. Some of the potassium feldspar and quartz were bound as coarsely-crystalline lithic fragments. Accessory phases include muscovite, which ranges from $0.1-<3 \%$ framework grains. 
Table 1-3: Normalized Modal Framework Grain Composition of MPAF Sandstone Deposits

\begin{tabular}{c|cccccccccc}
$\boldsymbol{F A}$ & Sample & $\boldsymbol{Q} \boldsymbol{t}$ & $\boldsymbol{F}$ & $\boldsymbol{L}$ & $\boldsymbol{Q m}$ & $\boldsymbol{F}$ & $\boldsymbol{L}$ & $\boldsymbol{Q m}$ & $\boldsymbol{P}$ & $\boldsymbol{K}$ \\
\hline $\boldsymbol{A 1}$ & $\mathbf{1}$ & 76.6 & 16.6 & 6.9 & 74.0 & 18.3 & 7.6 & 80.1 & 19.5 & 0.4 \\
$\boldsymbol{A 1}$ & $\mathbf{2}$ & 57.4 & 18.2 & 24.4 & 54.9 & 19.2 & 25.9 & 74.0 & 17.9 & 8.1 \\
$\boldsymbol{A 1}$ & $\mathbf{3}$ & 69.0 & 25.4 & 5.6 & 64.9 & 28.7 & 6.4 & 69.4 & 23.4 & 7.2 \\
$\boldsymbol{A 1}$ & $\mathbf{4}$ & 65.6 & 9.5 & 24.9 & 62.6 & 10.4 & 27.0 & 85.8 & 5.6 & 8.6 \\
$\boldsymbol{A 1}$ & $\mathbf{5}$ & 73.0 & 22.0 & 5.1 & 67.6 & 26.3 & 6.1 & 72.0 & 11.6 & 16.4 \\
$\boldsymbol{A 2}$ & $\mathbf{6}$ & 55.0 & 27.8 & 17.2 & 50.8 & 30.4 & 18.8 & 62.5 & 24.7 & 12.7 \\
$\boldsymbol{A 4}$ & $\mathbf{7}$ & 70.9 & 26.1 & 3.0 & 63.3 & 32.9 & 3.8 & 65.8 & 21.9 & 12.3 \\
$\boldsymbol{A 4}$ & $\mathbf{8}$ & 74.1 & 22.4 & 3.5 & 70.8 & 25.3 & 4.0 & 73.7 & 24.8 & 1.5 \\
$\boldsymbol{A 3}$ & $\mathbf{1 0}$ & 79.4 & 18.2 & 2.4 & 77.0 & 20.4 & 2.6 & 79.1 & 15.9 & 5.0 \\
$\boldsymbol{A 3}$ & $\mathbf{1 1}$ & 68.6 & 21.3 & 10.1 & 66.0 & 23.1 & 10.9 & 74.1 & 13.3 & 12.6 \\
$\boldsymbol{A 4}$ & $\mathbf{1 2}$ & 66.3 & 29.3 & 4.4 & 61.3 & 33.6 & 5.1 & 64.6 & 19.3 & 16.1 \\
$\boldsymbol{A 4}$ & $\mathbf{1 3}$ & 54.9 & 35.9 & 9.2 & 48.8 & 40.7 & 10.4 & 54.5 & 36.1 & 9.4 \\
$\boldsymbol{A 4}$ & $\mathbf{1 4}$ & 94.4 & 4.7 & 0.9 & 93.4 & 5.5 & 1.1 & 94.5 & 4.1 & 1.5
\end{tabular}

$\mathrm{FA}=$ Facies Association, $\mathrm{Qt}=$ Total quartz, $\mathrm{F}=$ Feldspar, $\mathrm{L}=$ Lithic, $\mathrm{Qm}=$ Monocrystalline quartz, $\mathrm{P}=$ Plagioclase feldspar, $\mathrm{K}=$ Potassium feldspar

Results for 5 sandstone thin-sections sampled from the low sinuosity fluvial channel (FA A1) exhibit a generally quartzofeldspathic composition (Table 1-3, Fig. 1-15; Average Qt-F-L of 68-18-14). Plagioclase feldspar is the dominant type of feldspar, forming an average of $11.8 \%$ of grain abundances (Fig. 1-15). The lithic grains range from 5-24\% of framework grains and are mostly sedimentary and metamorphic lithics.

One thin-section sampled from FA A2 shows a generally similar quartzofeldspathic composition including plagioclase and sedimentary and metamorphic lithic (Table 1-3), but with slightly lower Qt abundance of 55\%, compared to underlying samples of FA A1.

Two thin-section samples from the overlying FA A3 show a generally quartzofeldspathic composition with quartz abundances of $71 \%$ and $74 \%$ that are slightly higher than most underlying sandstone beds (Figure 1-15) (Table 1-3). Similar to underlying sandstone beds, monocrystalline quartz is the most abundant type of quartz and plagioclase is the dominant feldspar phase. Together, samples from FA A2 and FA A3 exhibit an increase in total feldspar abundance compared to FA A1.

Five thin-section sampled from FA A4 intervals show a generally quartzofeldspathic composition with increasing feldspar content (Table 1-3, Fig. 1-15). The basal FA A4 story, 
which is overlain by the $\mathrm{LKC}$, is quartz arenite (Qt-F-L $=94 \%, 5 \%, 1 \%$ ), while the topmost, stratigraphically youngest sandstone is quartzofeldspathic (Qt-F-L $=55 \%, 36 \%, 9 \%)$.

The braided channel and upper flow regime fluvial channel sandstone deposits (FA A2 and FA A3) indicate a mixed recycled orogeny and source to the south or east of the study area as indicated by the west to the northwestern direction of paleoflow. This is consistent with a source of uplifted Lower Paleozoic strata and/or low-grade metasedimentary rocks of the Alleghany fold-thrust belt. The abundant quartz in these sandstone deposits could also be due in part to intense chemical weathering. In contrast, the low sinuosity and sinuous fluvial channel sandstone deposits (FA A1 and FA A4) seem to be derived from recycled orogen and transitional continental sources respectively (Fig. 1-15). Since paleocurrent data indicate a similar northwestern paleoflow, this sediment composition change could indicate the addition of firstcycle sediment influx from coarsely crystalline metamorphic and/or igneous rocks of the Blue Ridge terrane. Contribution of this first-cycle sediment may have been a result of uplift or unroofing of the Blue Ridge rocks to provide a new source or due to an eastward expansion in the catchment area of the headwater streams feeding into the upper flow regime fluvial system. 

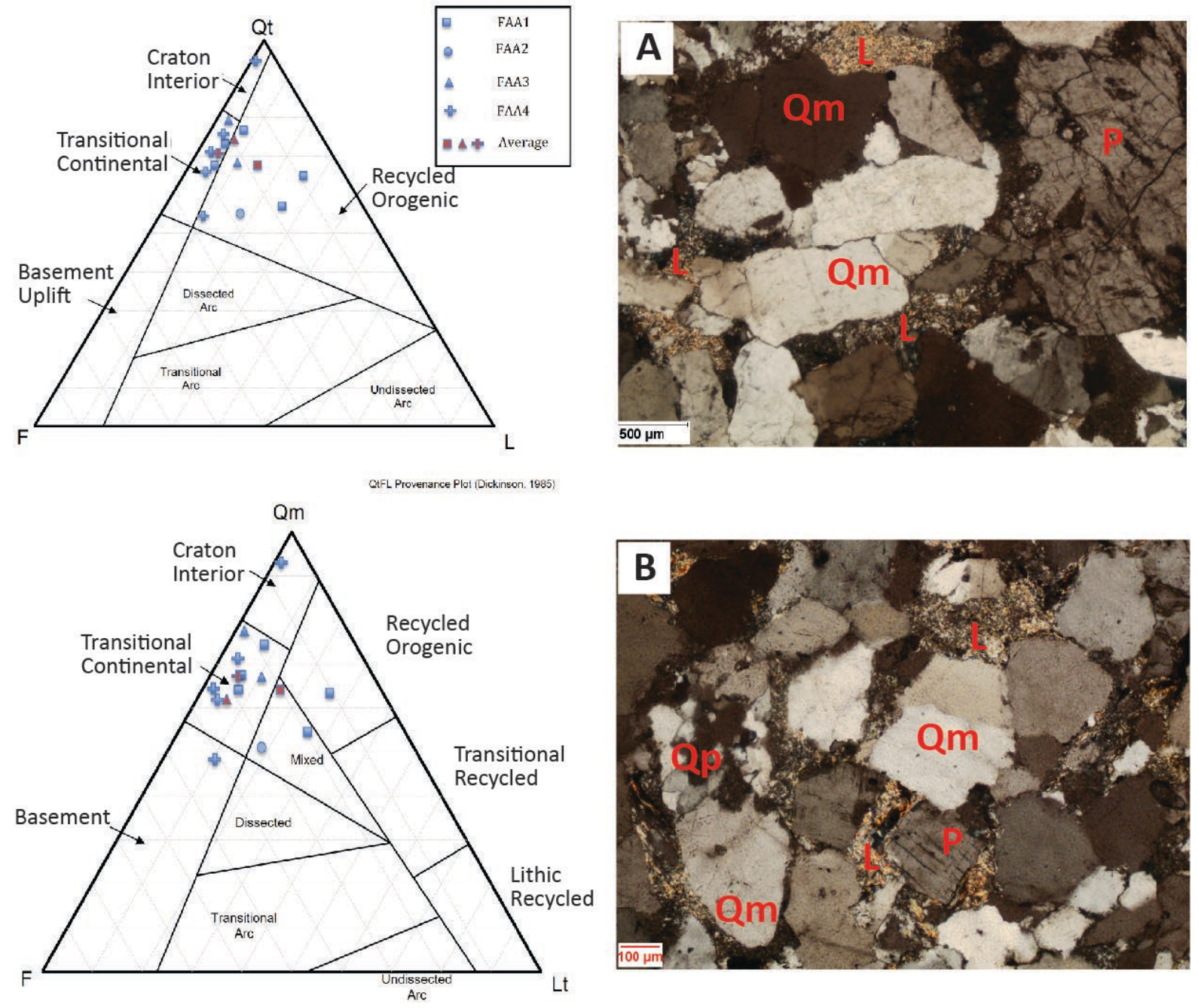

QmFLI Provenance Plot (Dickinson, 1985)
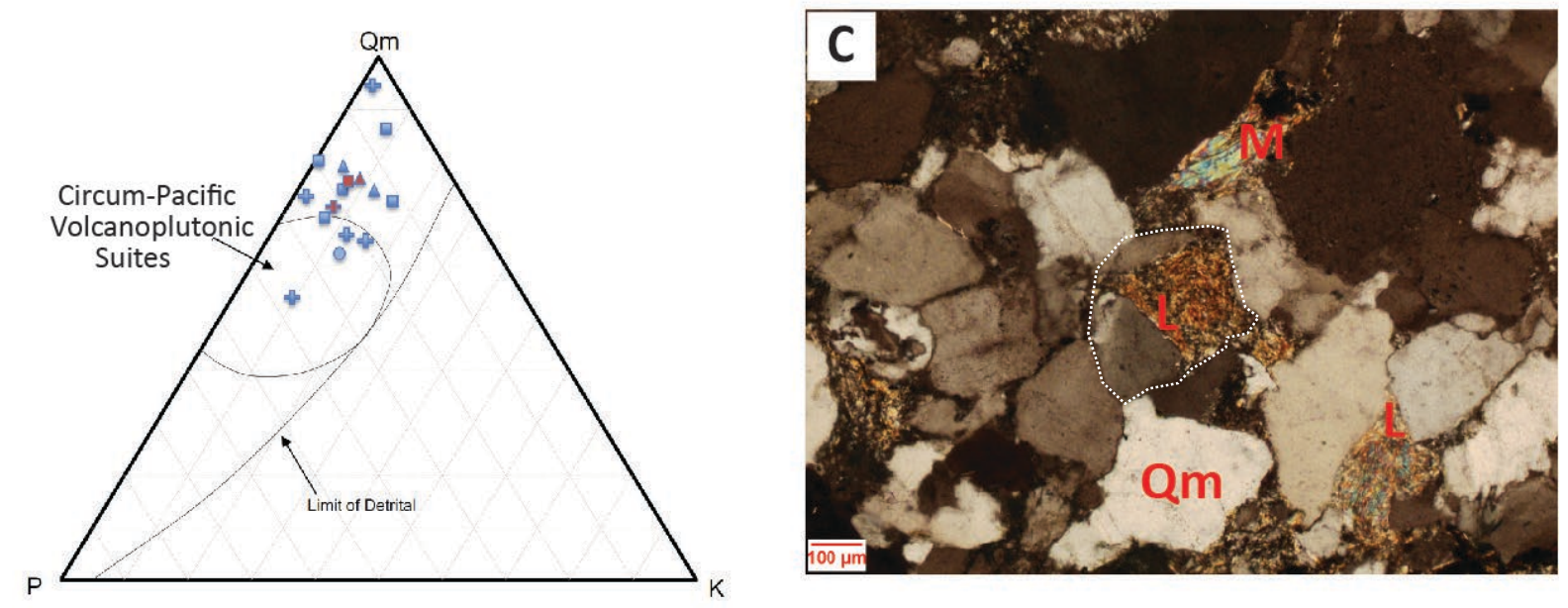
Figure 1-15: Ternary plots of modal sandstone grain compositions of channel deposits of the lower MPAF and thin section images. Qm = Monocrystalline quartz, $\mathrm{Qp}=$ Polycrystalline quartz, $\mathrm{P}=$ Plagioclase feldspar, $\mathrm{L}=$ Lithic and $\mathrm{M}=$ Mica.

\section{Discussion}

\subsection{Evolution of the Lower Middle Pennsylvanian Allegheny Formation Depositional Environments}

Sedimentary analysis of the Middle Pennsylvanian Allegheny Formation (MPAF) shows the evolution of fluvial systems with channel belts exhibiting mainly signatures of low sinuosity in FAA 1-3 and a change to high-sinuosity channel forms younger in FA A4 units.

The FA A1 represents a lower flow regime, low-sinuosity fluvial system that flowed westsouthwest. The framework grain composition of the low-sinuosity fluvial channel sandstone deposits indicate they are derived from a mixed northeastern transitional continental and recycled orogenic source. The abundance of planar and trough cross-beds in FA A1 indicates that the FA A1 fluvial system was dominated by lower flow regime currents. Although the abundance of stacked planar and trough cross-beds indicate deposition on channel floors, the absence of lateral accretion deposits in the FA A1 fluvial system indicates sediments were deposited primarily by channel aggradational. The sandstone beds of FA A1 contain abundant siderite and coal intraclast, which suggests incision and reworking by the fluvial system. An abundance of coal intraclast suggests may be due to an abundance of vegetation in the nearby environment.

FA A2, which represents a braided fluvial system flowing toward the northeast directly overlies and truncates FA A1. The framework grain composition of FA A2 derivation from a mixed recycled orogenic and transitional continental source. The change in fluvial styles suggests a reduction in channel flow depth or an increase in sediment supply of the FA A1 fluvial system. A drop in stratigraphic base-level in the fluvial system may have resulted in incision and change in fluvial style (Holbrook et al., 2006). The abundance of trough crossbedded sandstone suggests deposition by lower flow regime currents. The FA A2 sandstone contains less coal and no siderite intraclasts, which suggests the depositional environment had nearby vegetation but was not wet enough to allow for the formation of siderite. The absence of lateral accretion deposits and abundance of trough cross-beds indicate sediment deposition was mainly aggradational.

The FA A2 is overlain by well-drained floodplain and lacustrine delta deposits characterized by laterally extensive tabular sandstone, mudstone, shale and the No. 5 Block coal beds. The presence of well-drained floodplain and lacustrine delta deposits suggest that there was some inversion in gradient and a rise in the stratigraphic base-level of the fluvial system after FA A2 and FAA1 were deposited. The floodplain, lake and delta deposits are truncated and overlain by FA A3, which is characterized by upper flow regime current structures such as, horizontal laminated, low angle cross-bedded and convex upward sandstone, representing an upper flow regime, low-sinuosity fluvial system flowing northwestward. The framework grain composition of FA A3 indicates they are derived from a mixed transitional continental and recycled orogenic 
source. FA A3 systems lack coal and siderite intraclast, which may suggest limited channel incision and reworking of alluvial sediments.

FA A4 represents a high-sinuous fluvial system that flowed towards the northwest in a highly seasonal climatic environment. The framework grain composition of FA A4 indicates they are derived from a mixed transitional continental and basement source. FA A4 is characterized by abundant lateral accretion deposits which suggest sediment was deposited during lateral migration of channel. This resulted in a greater proportion of sediment deposited by lateral channel migration processes by FA A4 systems as opposed to previous channels in FA A1-3, which deposited sediment mainly from aggradation processes.

Lower FA A4 strata are overlain by poorly drained floodplain deposits characterized by shale, claystone, mudstones and the LKC coal bed, which indicates vegetation growth and deposition outpaced clastic sediment influx (Cecil, 2003; DiMichele, 2013; Falcon-Lang and DiMichele, 2010). FA A4 sandstone deposits of Channel belt complex 2 (C2), which are directly above FA A3 and below the LKC coal beds, are characterized by very high quartz composition (Qt-F-L = 94-5-1), deformed beds caused by soft-sediment deformation, and rooted beds. In contrast, the FA A4 deposits of Channel belt complex 3 (C3) which are overlying the LKC, are quartzofeldspathic and lacks root structures. The greater quartz content within the stratigraphically lower FA A4 deposits may be due to a high level of reworking of channel deposits. However, the higher feldspar content in older MPAF deposits (FA A1-3) and younger FAA4 deposits above the LKC coal beds, suggest minimal weathering or rapid erosion of an igneous or a metamorphic source rock. The presence of water escape structures indicates a high groundwater table, while the presence of vertical roots in the sandstone beds indicates some soil drainage which resulted in water levels that were low enough to allow for plant colonization. These root and water escape structures indicate that the FA A4 of C2 experienced periods of high water volume and periods of very low water volumes common in fluvial systems of highly seasonal wet-dry climate (Allen et al., 2014; Fielding et al., 2009; Plink-Björklund, 2015). This indicates the older FA A4 deposits below the LKC were deposited in a highly seasonal environment while the younger FA A4 deposited above the LKC, which lacked roots and deformed beds, were deposited in a non-seasonal environment.

\subsection{Controls on Fluvial Style}

\subsubsection{Tectonics}

Tectonic processes such as basin subsidence and uplift may have exerted control on basin gradient, nature of sediment supply and basin-wide accommodation of the fluvial system (Ettensohn, 2008; Holbrook et al., 2006; Holbrook and Schumm, 1999; Sak et al., 2012), which in turn may have influenced MPAF fluvial architecture. Previous tectonic models of the MPAF depositional setting suggests sedimentation in the Alleghenian foreland basin represents unloading lithosphere relaxation; this caused shallowing of the basin and accommodation decrease which facilitated progradation of sediments across the foredeep and fore-bulge (Ettensohn, 2008, 2005; Sak et al., 2012). This uplift may have affected the fluvial gradient and fluvial style and could also result in fluvial incision due to negative accommodation/relative base-level drop of the downstream reach compared to the upstream reach. 
Low-relief incision is evident in the facies architecture of the MPAF. The braided channel (FA A2), upper flow regime channel (FA A3) and sinuous channel below the LKC (FA A4) all incise into the underlying deposits have low mudrock content. This frequency of incision is higher than what would be expected/consistent with flexural uplift. However, the change in fluvial style from low sinuosity and high velocity of FA A1 - 3 to a more sinuous system of FA A4 possibly suggest a long-term reduction in basin slope (Holbrook et al., 2006; Holbrook and Schumm, 1999). Furthermore, the abundance of mudrock deposits in the sinuous channel deposits (FA A4) above the LKC, as well as in the low sinuosity channel deposits (FA A1) and poorly drained floodplain deposits (FA B1) are consistent with deposition in an increasing accommodation basin setting. Uplift from lithosphere relaxation would reduce accommodation and should result in low mudrock to sandstone ratio in fluvial strata. Together, these observations suggest the MPAF primarily accumulated under conditions of overall decreasing slope, consistent with basin subsidence rather than uplift.

\subsubsection{Glacio-eustasy \& Paleoclimate}

During the late Paleozoic Ice Age, the glacio-eustatic control on base-level rise and fall and climate patterns in the Appalachian basin may have affected the fluvial stacking pattern of the MPAF (Falcon-Lang, 2004; Falcon-Lang and DiMichele, 2010). Glaciation was continuous from middle Mississippian to middle Permian, causing $3^{\text {rd }}$ order cyclic sea-level changes of $\sim 30-100$ $\mathrm{m}$ that produced stratigraphic cyclothems (Arkle Jr et al., 1979; DiMichele et al., 2010; FalconLang, 2004; Greb et al., 2008; Isbell et al., 2003; Montañez et al., 2007). Also, paleoclimate in the Appalachian basin shifted from ever-wet humid to perhumid climate during the mid- to late sea-level lowstand of glacial periods to a seasonal semi-arid/sub-humid climate during interglacial periods (Cecil, 2003; Falcon-Lang and Dimichele, 2010; DiMichele, 2013). A northward drift of the ITCZ during interglacial caused several months of dry, sub-arid conditions each year, whereas during glacial periods, the ITCZ shifted to a more equatorial position causing high rainfall in the Allegheny foreland (Cecil et al., 2004, 2003b; Poulsen et al., 2007).

Paleosol evidence indicates the falling stages of sea-level to early sea-level lowstand was accompanied by climatic seasonality (Cecil, 2003; DiMichele, 2013; Joeckel, 1994). Peat swamp deposits then likely developed over the duration of glacial maxima under climate conditions in which rainfall exceeded evapotranspiration >10 months out of the year (Cecil, 2013, 2003; DiMichele, 2013). Base-level fall during glacial maxima was then a period of widespread peat aggradation across Pangea leading to a decrease in sediment accommodation. During early sealevel rise and initiation of the interglacial period, rainfall decreased, and the region experienced fluvial channel incision. As interglacial sea-level rise accelerated, channel sandstone deposits aggraded to form the amalgamated, multistory channel complexes from abundant sediment developed from erosion during the preceding glacial period. This sediment was transported into the lower accommodation basin setting, leading to deposition of fluvial channel deposits across the basin. Sediment bypass was likely significant during this period and would have fed sandrich shoreline systems. As sea-level rise decelerated during the peak interglacial period, the increased sediment accommodation and increased base-level led channels to become singlethread, confined systems, eventually transitioning to a system of dominated by wide-spread aggradation of floodplain mudrocks across the basin (Falcon-Lang and Dimichele, 2010). 
Evaluating the MPAF deposits for glacio-eustatic control suggests FA A1-4 were deposited during glacial-interglacial transitions, when the eustatic base-level was low and beginning to increase, whereas the poorly drained floodplain deposits (FAB1), well-drained floodplain deposits (FAB2) and swamp/mire deposits (FAB4) were deposited during peak interglacial periods when base-level was high/increasing. Peat swamp/mire deposits (FA B4) formed during the transition from interglacial to glacial period when climate in the Appalachian basin was more likely to be ever-wet (DiMichele, 2013). The deposits accumulated during the glacial period are most likely to be subsequently removed during incision associated with the subsequent glacial-interglacial transition erosion and fluvial downcutting. Possibly the high resistance of peat to erosion contributed to the preservation of these deposits.

The effect of glacial-interglacial variability in precipitation rates may influence fluvial style through supply of water to the system, velocity of flow, sediment yield and the effect of vegetation on the stability of channel banks (Cecil and Dulong, 2003; Davies and Gibling, 2013; Fielding et al., 2009; Gibling et al., 2014; Plink-Björklund, 2015; Schumm, 1981). Fluvial systems in climates with constant rainfall throughout the year usually have a consistent flow, while fluvial systems with low annual seasonal precipitation are generally starved of water and do not have a consistent volume of flow year-round. Channel belt complex 1 and 2, which comprises upper flow regime channel and sinuous channel with variable flow velocity structures (FA A3 and FA A4) have features of a seasonal, semi-arid fluvial systems commonly found in fluvial channels in a monsoonal climate, while the Channel belt complex 3 which comprises mainly of the sinuous channel deposits (FA A4) have feature of fluvial systems in a humid climate. The Channel belt complex 1, which comprises the low sinuosity channel and braided channel (FA A1 and FA A2) have features that are characteristic of a semi-humid depositional environment. The variation in style of fluvial systems that developed during the glacialinterglacial transitions of the MPAF may have been influenced by changing water discharge and sediment load. An increased sediment load along with lower discharge associated with the developing interglacial climate may also contribute to the formation the braided channel (FA A2) and the low sinuosity fluvial system (FA A1). The change in fluvial style from a braided/straight channel to more sinuous/meandering channels may reflect a lower gradient, suggesting development during eustatic base-level drop of a glacial period instead of the glacial-interglacial transition (Holbrook and Schumm, 1999). However, the lack of evidence that indicates marine transgression in the MPAF, suggests that eustatic processes had minimal control on fluvial style evolution of the MPAF (e.g., Holbrook et al., 2006). Instead, climate control on discharge and vegetation via increasing seasonality of precipitation along with base-level control by downstream processes influenced the fluvial style evolution.

Facies architecture, sediment type and grain sizes of the low sinuously fluvial channel (FA A1) indicate fluctuating paleoflow velocities and sedimentation by a perennial system in a semihumid system with increasing seasonality in precipitation. The most common sedimentary structures of FA A1 channel bodies are planar horizontal laminated bedding, which transitions to trough cross-bedding which suggests sedimentation during high-velocity flow and moderate velocity flow, respectively. The gradational transition of bedforms within the FA A1 story suggests deposition under a continuous flow of water during a single event (Bridge, 2009; Miall, 1996). The repetitive nature and the facies architecture of FA A1 deposits indicate they are 
deposits of a fluvial system with variable flow velocities but continuous flow, which is characteristic of perennial fluvial systems. Studies of miospore population in the MPAF at Birch River showed that lycopsids, which are common in wet humid environment, decreased in the Lower Kittanning coal beds, while ferns, which are more common in seasonal wet-dry environments, increased in the No. 5 Block and upper No. 5 Block coal beds, which suggest a change to a wet-dry seasonal system which is common in fluvial systems in monsoonal climate (Figure 1-16) (Cecil et al., 2003b; DiMichele et al., 2010; Eble, 2002; Falcon-Lang and DiMichele, 2010; Plink-Björklund, 2015).

Facies architecture and sediment type of the braided fluvial channel (FA A2) suggest deposition by a perennial, multi-threaded channel system with variable flow conditions. Multiple stories of trough cross-beds with a similar thickness of preserved cross set and bounded above and below by sharp erosional were interpreted as sheet deposits of a braided fluvial system (Allen et al., 2011b; Gibling et al., 2014; Medici et al., 2015). The repetitive story and similar thickness of preserved limbs of trough cross-bedded sandstone in FA A2 suggest they are perennial deposits with consistent flow depth. Coal clast are abundant in both low-sinuosity (FA A1) and braided channels (FA A2), and absent in other channel deposits of the MPAF, suggests that the fluvial systems had incised and reworked underlying deposits.

The facies architecture and sedimentary features of the upper flow regime (FA A3) and sinuous (FA A4) fluvial channel deposits below the LKC indicate they are deposits of intermittent to perennial fluvial systems of a seasonal semi-arid/ semi-humid climate. The FA A3 deposits are characterized by upper flow regime structures such as horizontal planar laminated sandstone beds (Sh facies) and low-angle cross-bedded sandstone (Sl facies). The Sh facies transition abruptly into overlying Sl facies, which also transition abruptly back to Sh facies. The abrupt transitions between upper and lower flow regime structures has been attributed to variation in flow conditions during flash floods in fluvial systems of semi-arid regions (Fielding et al., 2009; Plink-Björklund, 2015). Below the LKC, the sinuous channel deposits (FA A4) overlie the upper plane beds of FA A3 and are characterized by deformed convoluted beds in the upper section and have in-situ root structure and rootlets in them (Figure 1-10). The softsediment deformation in the fluvial deposits modeled by previous studies has been attributed to water escape from oversaturated strata inundated by the onset of increasing volume of flooding waters (Cecil et al., 2003b; Cecil and Dulong, 2003; Fielding et al., 2009; Plink-Björklund, 2015). The high volumes of floodwaters may be due to seasonal high-volume precipitation, during the wet season in a semi-arid system characterized by wet-dry seasonal climate (Cecil et al., 2003a, 2003b; Cecil and Dulong, 2003; DiMichele et al., 2010; Falcon-Lang, 2004; PlinkBjörklund, 2015).

The presence of in-situ root structures in the deformed beds is likely due to plants growing within the channels due to low water levels as observed in modern fluvial analogs of seasonal semi-arid climates (Allen et al., 2014; Fielding et al., 2009; Plink-Björklund, 2015). The presence of both rootlets and soft-sediment deformation structures in the FAA4 sandstone overlain by the LKC indicate sedimentation by a fluvial system with both high and low volumes level of water, which is common in fluvial systems of seasonal, semi-arid regions (Allen et al., 2014; Fielding et al., 2009; Fielding and Alexander, 1996). Floating coal clast or siderite are rare 
in FAA3 and FAA4 deposits, suggesting less fluvial incision and reworking of floodplain/peat swamp environments, or that the reworked floodplain/peat swamp deposits contained lower abundances of siderite and peat due to overall drier climate conditions during deposition.

The variation in the facies architecture of non-channel deposits of the MPAF (FA B1 - 4) may also be a response to the increasing seasonality of precipitation due to changing paleoclimate during glacial-interglacial cycles. Well-drained floodplain deposits of FA B2 are found above braided fluvial deposits (FA A2) and below the Upper No. 5 coal (FA B4) and overlying FA A3 which were interpreted as fluvial systems of seasonal, semi-arid climate. Formation of these well-drained floodplain deposits were triggered by transitioning climate into an interglacial period as sea-level rise increased accommodation in the basin. The low mudrock-sand ratio in the well-drained floodplain deposits is likely due to decreased precipitation relative to evapotranspiration in a seasonal, semi-arid climate, such that organic sediment was generated at a slower rate and was more likely to be diluted by the influx of siliciclastic detritus. Upsection, the poorly-drained floodplain deposits of FA B1 are found below the LCK (FA B4) and overlying sinuous fluvial deposits (FA A4) interpreted to represent deposition at the initiation of in an increasingly ever-wet humid climate. FA B3 and represents lacustrine delta deposits characterized by planar, tabular sandstone, siltstone and shale deposits. FA B3 were deposited over the well-drained floodplain deposit and are overlain by the Upper No. 5 Block coal bed in places. The lacustrine deposit is due to an autogenic reduction in gradient and variation in stratigraphic base-level of the floodplain in a wet-dry seasonal climate. Similar to the welldrained floodplain, the poorly-drained floodplain deposits also formed under an interglacial climate, however, during this climate cycle, the interglacial period was not as dry as the last interglacial stage. The high mudrock to sand ratio in the poorly drained floodplain may have been due to an increased rate of organic matter deposition facilitated by high precipitation to evapotranspiration in an ever-wet climate that was too low for peat formation but high enough to generate organic sediment. Notably, the coal thicknesses of the FA B4 also decrease with time from the No. 5 to Upper No. 5 and LKC. These relationships suggest that over time, as the LPIA evolved toward its maximum glacial conditions in the early Late Pennsylvanian, the glacial periods became less wet, as the interglacial periods became more wet, indicating climate was becoming less extreme (Figure 1-16). 


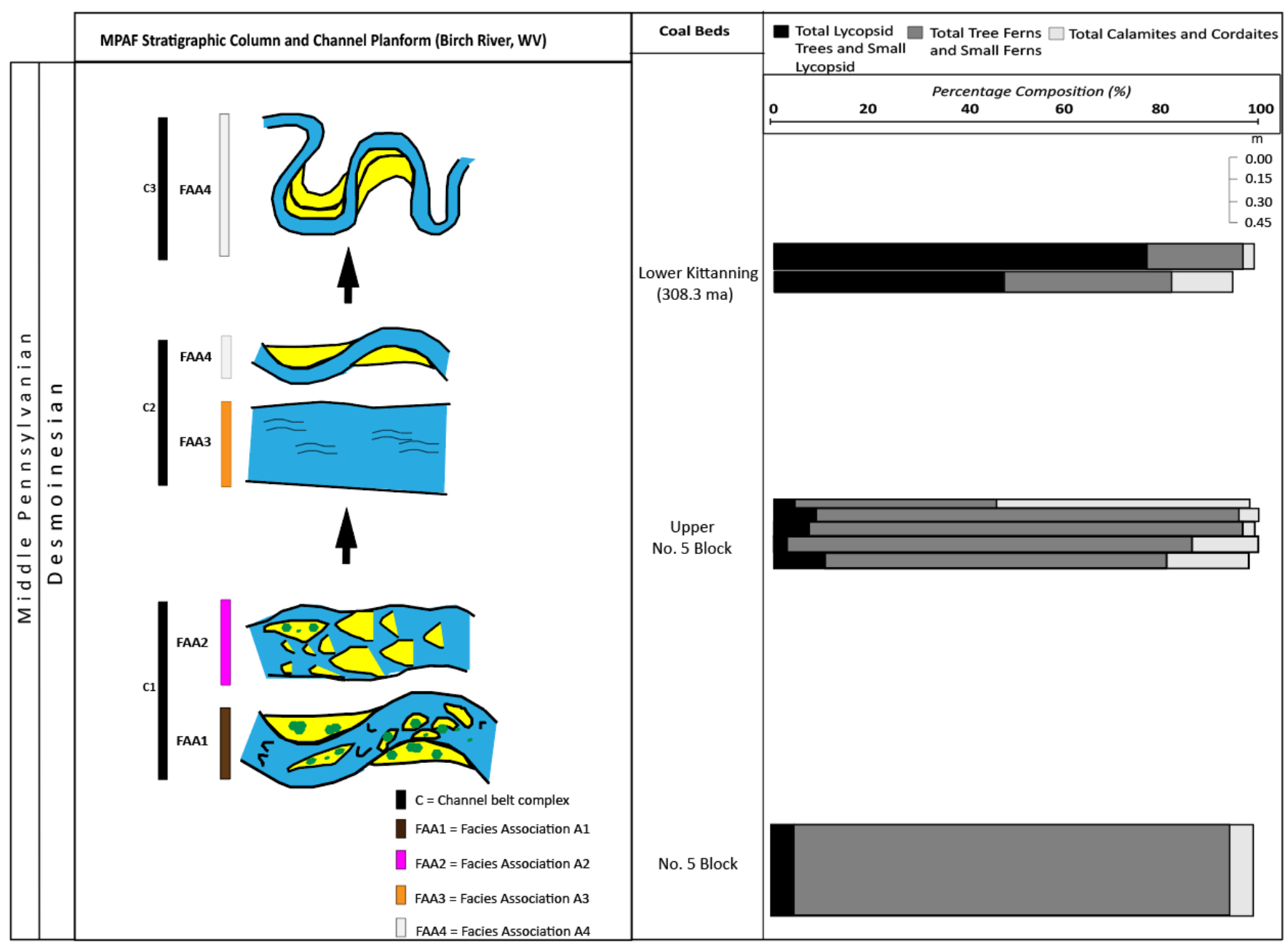

Figure 1-16: Miospore population and MPAF channel styles through time. Image modified from Eble (2002).

\section{Conclusions}

Facies architecture analysis of the Middle Pennsylvanian Allegheny Formation (MPAF) at Birch River revealed ten lithofacies and eight facies association including both channel and nonchannel deposits. The channel deposits represent four channel styles which include deposits of a low sinuosity (FAA1), braided (FAA2), upper flow regime (FAA3) and sinuous (FAA4) fluvial systems. The non-channel deposits include poorly-drained floodplain (FAB1), well-drained floodplain (FAB2), lacustrine delta (FAB3), and swamp (FAB4) deposits. Below the Lower Kittanning coal bed (LKC), the fluvial deposits contain very low angle cross-beds, planar crossbeds and laminated sandstone and siltstone that form sheets and downstream accreting bar elements, reflecting deposition by low sinuosity systems with perennial flows of variable velocity, indicative of highly seasonal discharge. This, along with water escape and root 
structures of the low sinuosity channel below the Lower Kittanning coal bed (LKC) are common in fluvial systems of seasonally wet-dry semi-humid/semi-arid climate. In contrast, the fluvial channels above the LKC are dominated by lower flow regime indicators within concave-upward sandstone lenses and lateral-accretion bar elements that reflect deposition by sinuous, meandering fluvial channels with perennial flow conditions. In particular, the higher mudrock content in channel sands of the sinuous fluvial deposits is common in fluvial systems of ever-wet humid environments.

Petrographic analysis indicates that the FAA1 - 4 channels sandstone deposits are quartzofeldspathic, and that fluvial sandstone deposits below the LKC have higher quartz content (94\% compared to 74\%). Paleocurrent and petrology analysis indicate westward and northwestward flow of channels transporting sediment derived from transitional continental and recycled orogenic sources. Modal framework grain composition shows that the Overall, feldspar grain abundances and lithic grains abundance decreased, which suggests input of first cycle sediment into the fluvial system also decreased, resulting in more quartzose sediment. Original first-cycle sediment may reflect erosion of one or more unroofed Appalachian orogen plutons or rocks of the Blue Ridge/Piedmont terranes. The subsequent decrease in first-cycle sediment influx may indicate a change in source area through drainage capture to include more sedimentary source rocks or increased chemical weathering or increased alluvial reworking and degradation of the less stable feldspar and lithic grains.

Together, facies stacking patterns and mineral composition due to paleoclimate change from ever-wet humid climate to a seasonal sub-arid climate indicate that paleoclimate was a major control on the MPAF fluvial architecture. Furthermore, facies architectural analysis suggest sedimentation occurred over cyclic ever-wet humid to seasonally wet-dry (semihumid/semi-arid) depositional environments. Though glacio-eustasy and tectonics exert more dominance on basin-wide base-level rise and fall, and hence accommodation, the occurrence of descriptive lithologies such as abundant siderite, water escape structure and rooted channel deposits suggest a wet-dry change in paleoclimate occurred during MPAF deposition. In each of the multistory channel complexes fluvial sandstone units of the Allegheny Formation above and below the Lower Kittanning coal bed (LKC) record evolution from multi-thread to single thread systems determined from distinctive sedimentary features. This study shows that changes in fluvial style, sedimentology and mineralogical composition can be used to evaluate paleoclimatic variations. 


\section{References}

Abatan, O., and Weislogel, A., 2020, Paleohydrology and Machine-Assisted Estimation of Paleogeomorphology of Channels of the Lower-Middle Pennsylvanian Allegheny Formation, Birch River, WV: Frontiers in Earth Science, v. 7, doi:10.3389/feart.2019.00361.

Allen, J., 1979. Studies in fluviatile sedimentation: An elementary geometrical model for the connectedness of avulsion-related channel sand bodies. Sedimentary Geology 24, 253 267.

Allen, J.P., Fielding, C.R., Gibling, M., Rygel, M.C., 2011a. Fluvial response to paleo-equatorial climate fluctuations during the late Paleozoic ice age. http://dx.doi.org/10.1130/B30314.1

Allen, J.P., Fielding, C.R., Gibling, M.R., Rygel, M.C., 2014. Recognizing products of paleoclimate fluctuation in the fluvial stratigraphic record: An example from the Pennsylvanian to Lower Permian of Cape Breton Island, Nova Scotia. Sedimentology 61, 1332-1381.

Allen, J.P., Fielding, C.R., Gibling, M.R., Rygel, M.C., 2011b. Fluvial response to paleoequatorial climate fluctuations during the late Paleozoic ice age. Geological Society of America Bulletin 123, 1524-1538.

Allen, J.R., 1982. Sedimentary structures, their character and physical basis. Elsevier Science \& Technology.

Allen, J.R.L., 1970. A quantitative model of grain size and sedimentary structures in lateral deposits. Geological Journal 7, 129-146. https://doi.org/10.1002/gj.3350070108

Arkle Jr, T., Beissel, D.R., Larese, R.E., Nuhfer, E.B., Patchen, D.G., Smosna, R.A., Gillespie, W.H., Lund, R., Norton, C.W., Pfefferkorn, H.W., 1979. Mississippian and Pennsylvanian (carboniferous) systems in the United States: West Virginia and Maryland. US, Geol. Surv., Prof. Pap.;(United States) 1110.

Belt, E.S., Heckel, P.H., Lentz, L.J., Bragonier, W.A., Lyons, T.W., 2011. Record of glacialeustatic sea-level fluctuations in complex middle to late Pennsylvanian facies in the Northern Appalachian Basin and relation to similar events in the Midcontinent basin. Sedimentary Geology 238, 79-100. https://doi.org/10.1016/j.sedgeo.2011.04.004

Bhattacharya, J.P., Tye, R.S., 2004. Searching for modern Ferron analogs and application to subsurface interpretation. Regional to wellbore analog for fluvial-deltaic reservoir modeling: The Ferron Sandstone of Utah: AAPG Studies in Geology 50, 39-57. 
Blake, B.M., Cross, A.T., Eble, C.F., Gillespie, W.H., Pfefferkorn, H.W., 2002. Selected plant megafossils from the Carboniferous of the Appalachian Region, Eastern United States: geographic and stratigraphic distribution. Memoir-Canadian Society of Petroleum Geologists 19, 259-335.

Blakey, R.C., 2018. Deep Time Maps ${ }^{\mathrm{TM}}$ - maps of ancient Earth. URL //deeptimemaps.com/ (accessed 10.16.19).

Blum, M.D., Törnqvist, T.E., 2000. Fluvial responses to climate and sea-level change: a review and look forward. Sedimentology 47, 2-48.

Braccini, E., De Boer, W., Hurst, A., Huuse, M., Vigorito, M., Templeton, G., 2008. Sand injectites. Oilfield Review 20, 34-49.

Bridge, J.S., 2009. Rivers and floodplains: forms, processes, and sedimentary record. John Wiley \& Sons.

Catuneanu, O., 2006. Principles of sequence stratigraphy. Elsevier, Amsterdam; Boston.

Cecil, C.B., 2013. An overview and interpretation of autocyclic and allocyclic processes and the accumulation of strata during the Pennsylvanian-Permian transition in the central Appalachian Basin, USA. International Journal of Coal Geology, SI:Dunkard Group Geology 119, 21-31. https://doi.org/10.1016/j.coal.2013.07.012

Cecil, C.B., 2003. Climate controls on the stratigraphy of a Middle Pennsylvanian cyclothem in North America.

Cecil, C.B., 1990. Paleoclimate controls on stratigraphic repetition of chemical and siliciclastic rocks. Geology 18, 533-536.

Cecil, C.B., Brezinski, D.K., Dulong, F., 2004. The Paleozoic record of changes in global climate and sea level: Central Appalachian Basin. Geology of the National Capital Region-Field Trip Guidebook: US Geological Survey Circular 1264, 77-133.

Cecil, C.B., Dulong, F.T., 2003. Precipitation models for sediment supply in warm climates. SEPM Society for Sedimentary Geology 77, 21-27.

Cecil, C.B., Dulong, F.T., Harris, R.A., Cobb, J.C., Gluskoter, H.G., Nugroho, H., 2003a. Observations on climate and sediment discharge in selected tropical rivers, Indonesia.

Cecil, C.B., Dulong, F.T., West, R.R., Stamm, R., Wardlaw, B., Edgar, N.T., 2003b. Climate controls on the stratigraphy of a Middle Pennsylvanian cyclothem in North America, in: Cecil, C.B., Edgar, N.T. (Eds.), Climate Controls on Stratigraphy. SEPM Society for Sedimentary Geology, p. 0. https://doi.org/10.2110/pec.03.77.0151 
Cecil, C.B., Stanton, R.W., Neuzil, S.G., Dulong, F.T., Ruppert, L.F., Pierce, B.S., 1985.

Paleoclimate controls on late Paleozoic sedimentation and peat formation in the central Appalachian Basin (USA). International Journal of Coal Geology 5, 195-230.

Davies, N.S., Gibling, M.R., 2013. The sedimentary record of Carboniferous rivers: continuing influence of land plant evolution on alluvial processes and Palaeozoic ecosystems. EarthScience Reviews 120, 40-79.

Davies, N.S., Gibling, M.R., Rygel, M.C., 2011. Alluvial facies evolution during the Palaeozoic greening of the continents: case studies, conceptual models and modern analogues. Sedimentology 58, 220-258.

Dickinson, W.R., 1985. Interpreting Provenance Relations from Detrital Modes of Sandstones, in: Zuffa, G.G. (Ed.), Provenance of Arenites. Springer Netherlands, Dordrecht, pp. 333361. https://doi.org/10.1007/978-94-017-2809-6_15

DiMichele, W.A., 2013. Wetland-dryland vegetational dynamics in the Pennsylvanian ice age tropics. International Journal of Plant Sciences 175, 123-164.

DiMichele, W.A., Cecil, C.B., Montañez, I.P., Falcon-Lang, H.J., 2010. Cyclic changes in Pennsylvanian paleoclimate and effects on floristic dynamics in tropical Pangaea. International Journal of Coal Geology 83, 329-344.

Donaldson, A.C., Eble, C., 1991. Pennsylvanian coals of central and eastern United States. The Geology of North America: Economic Geology, US 523-46.

Donaldson, A.C., Renton, J.J., Presley, M.W., 1985. Pennsylvanian deposystems and paleoclimates of the Appalachians. International Journal of Coal Geology 5, 167-193.

Donaldson, A.C., Shumaker, R.C., 1981. Late Paleozoic molasse of central Appalachians. Sedimentation and tectonics in alluvial basins: Geological Association of Canada Special Paper 23, 99-124.

Eble, C.F., 2002. Palynology of late Middle Pennsylvanian coal beds in the Appalachian Basin. International Journal of Coal Geology 50, 73-88.

Ettensohn, F.R., 2008. Chapter 4 The Appalachian Foreland Basin in Eastern United States, in: Miall, A.D. (Ed.), Sedimentary Basins of the World, The Sedimentary Basins of the United States and Canada. Elsevier, pp. 105-179.

Ettensohn, F.R., 2005. 5. The sedimentary record of foreland-basin, tectophase cycles: Examples from the Appalachian Basin, USA, in: Mabessoone, J.M., Neumann, V.H. (Eds.), Developments in Sedimentology, Cyclic Development of Sedimentary Basins. Elsevier, pp. 139-172. https://doi.org/10.1016/S0070-4571(05)80007-X 
Falcon-Lang, H.J., 2004. Pennsylvanian tropical rain forests responded to glacial-interglacial rhythms. Geology 32, 689-692. https://doi.org/10.1130/G20523.1

Falcon-Lang, H.J., Dimichele, W.A., 2010. What happened to the coal forests during Pennsylvanian glacial phases? Palaios 25, 611-617.

Falcon-Lang, H.J., Heckel, P.H., Dimichele, W.A., Blake Jr, B.M., Easterday, C.R., Eble, C.F., Elrick, S., Gastaldo, R.A., Greb, S.F., Martino, R.L., 2011. No major stratigraphic gap exists near the middle-upper Pennsylvanian (Desmoinesian-Missourian) boundary in North America. Palaios 26, 125-139.

Ferm, J.C., 1970. Allegheny deltaic deposits.

Fielding, C.R., Alexander, J., 1996. Sedimentology of the Upper Burdekin River of North Queensland, Australia - an example of a tropical, variable discharge river. Terra Nova 8, $447-457$.

Fielding, C.R., Allen, J.P., Alexander, J., Gibling, M.R., 2009. Facies model for fluvial systems in the seasonal tropics and subtropics. Geology 37, 623-626.

Flood, Y.S., Hampson, G.J., 2014. Facies and architectural analysis to interpret avulsion style and variability: Upper Cretaceous Blackhawk Formation, Wasatch Plateau, Central Utah, USA. Journal of Sedimentary Research 84, 743-762.

Gibling, M.R., 2006. Width and thickness of fluvial channel bodies and valley fills in the geological record: a literature compilation and classification. Journal of sedimentary Research 76, 731-770.

Gibling, M.R., Davies, N.S., Falcon-Lang, H.J., Bashforth, A.R., DiMichele, W.A., Rygel, M.C., Ielpi, A., 2014. Palaeozoic co-evolution of rivers and vegetation: a synthesis of current knowledge. Proceedings of the Geologists' Association 125, 524-533.

Greb, S.F., Pashin, J.C., Martino, R.L., Eble, C.F., 2008. Appalachian sedimentary cycles during the Pennsylvanian: Changing influences of sea level, climate, and tectonics. Geological Society of America Special Papers 441, 235-248. https://doi.org/10.1130/2008.2441(16)

Holbrook, J., Schumm, S.A., 1999. Geomorphic and sedimentary response of rivers to tectonic deformation: a brief review and critique of a tool for recognizing subtle epeirogenic deformation in modern and ancient settings. Tectonophysics 305, 287-306.

Holbrook, J., Scott, R.W., Oboh-Ikuenobe, F.E., 2006. Base-level buffers and buttresses: a model for upstream versus downstream control on fluvial geometry and architecture within sequences. Journal of Sedimentary Research 76, 162-174. 
Ingersoll, R.V., Bullard, T.F., Ford, R.L., Grimm, J.P., Pickle, J.D., Sares, S.W., 1984. The effect of grain size on detrital modes: a test of the Gazzi-Dickinson point-counting method. Journal of Sedimentary Research 54, 103-116.

Isbell, J.L., Miller, M.F., Wolfe, K.L., Lenaker, P.A., 2003. Timing of late Paleozoic glaciation in Gondwana: Was glaciation responsible for the development of Northern Hemisphere cyclothems? Special papers-geological society of America 5-24.

Joeckel, R.M., 1994. Virgilian (Upper Pennsylvanian) Paleosols in the upper Lawrence Formation (Douglas Group) and its Snyderville Shale Member (Oread Formation, Shawnee Group) of the northern Midcontinent, USA; pedologic contrasts in a cyclothem sequence. Journal of Sedimentary Research 64, 853-866.

Kosanke, R.M., Cecil, C.B., 1996. Late Pennsylvanian climate changes and palynomorph extinctions. Review of Palaeobotany and Palynology, Palaezoic Phytogeography 90, 113-140. https://doi.org/10.1016/0034-6667(95)00027-5

Leclair, S.F., Bridge, J.S., 2001. Quantitative interpretation of sedimentary structures formed by river dunes. Journal of Sedimentary Research 71, 713-716.

Luttrell, P.R., 1993. Basinwide sedimentation and the continuum of paleoflow in an ancient river system: Kayenta Formation (Lower Jurassic), central portion Colorado Plateau. Sedimentary Geology 85, 411-434.

Makaske, B., Smith, D.G., Berendsen, H.J., 2002. Avulsions, channel evolution and floodplain sedimentation rates of the anastomosing upper Columbia River, British Columbia, Canada. Sedimentology 49, 1049-1071.

Matthews, M.D., Perlmutter, M.A., 1994. Global cyclostratigraphy: an application to the Eocene Green River Basin, in: Orbital Forcing and Cyclic Sequences. Spec. Publ. Int. Ass. Sediment, pp. 459-481.

Medici, G., Boulesteix, K., Mountney, N.P., West, L.J., Odling, N.E., 2015. Palaeoenvironment of braided fluvial systems in different tectonic realms of the Triassic Sherwood Sandstone Group, UK. Sedimentary geology 329, 188-210.

Miall, A., 2014. Fluvial Depositional Systems. Springer International Publishing, Cham. https://doi.org/10.1007/978-3-319-00666-6

Miall, A.D., 1996. The geology of fluvial deposits. Springer.

Miall, A.D., 1985. Architectural-element analysis: a new method of facies analysis applied to fluvial deposits. Earth-Science Reviews 22, 261-308. 
Montañez, I.P., McElwain, J.C., Poulsen, C.J., White, J.D., DiMichele, W.A., Wilson, J.P., Griggs, G., Hren, M.T., 2016. Climate, pCO2 and terrestrial carbon cycle linkages during late Palaeozoic glacial-interglacial cycles. Nature Geoscience 9, 824.

Montañez, I.P., Tabor, N.J., Niemeier, D., DiMichele, W.A., Frank, T.D., Fielding, C.R., Isbell, J.L., Birgenheier, L.P., Rygel, M.C., 2007. CO2-forced climate and vegetation instability during Late Paleozoic deglaciation. Science 315, 87-91.

Olsen, H., de Boer, P.L., Smith, D.G., 1994. Orbital forcing on continental depositional systems - lacustrine and fluvial cyclicity in the Devonian of East Greenland, in: Orbital Forcing and Cyclic Sequences. International Association of Sedimentologists, Special Publication, pp. 429-438.

Owen, G., Moretti, M., 2011. Identifying triggers for liquefaction-induced soft-sediment deformation in sands. Sedimentary Geology, Recognising triggers for soft-sediment deformation: Current understanding and future directions 235, 141-147. https://doi.org/10.1016/j.sedgeo.2010.10.003

Peppers, R.A., 1996. Palynological correlation of major Pennsylvanian (Middle and Upper Carboniferous) chronostratigraphic boundaries in the Illinois and other coal basins. Geological Society of America.

Plink-Björklund, P., 2015. Morphodynamics of rivers strongly affected by monsoon precipitation: Review of depositional style and forcing factors. Sedimentary Geology 323, 110-147. https://doi.org/10.1016/j.sedgeo.2015.04.004

Poulsen, C.J., Pollard, D., Montañez, I.P., Rowley, D., 2007. Late Paleozoic tropical climate response to Gondwanan deglaciation. Geology 35, 771-774.

Repine, T.E., Blake, B.M., Ashton, K.C., Fedorko, N., Keiser, A.F., Loud, E.I., Smith, C.J., McClelland, S.W., McColloch, G.H., 1993. Regional and economic geology of Pennsylvanian age coal beds of West Virginia. International journal of coal geology 23, 75-101.

Sak, P.B., McQuarrie, N., Oliver, B.P., Lavdovsky, N., Jackson, M.S., 2012. Unraveling the central Appalachian fold-thrust belt, Pennsylvania: The power of sequentially restored balanced cross sections for a blind fold-thrust belt. Geosphere 8, 685-702.

Schumm, S.A., 1988. Variability of the fluvial system in space and time. Scales and global change $225-250$.

Schumm, S.A., 1981. Evolution and response of the fluvial system, sedimentologic implications.

Stubbs, D.G., 2018. A Sequence Stratigraphic Analysis of the Allegheny Group (Middle Pennsylvanian), Southeast Ohio (Masters Thesis). Ohio University. 
Zahid, K.M., Barbeau, D.L., 2011. Constructing Sandstone Provenance and Classification Ternary Diagrams Using An Electronic Spreadsheet. Journal of Sedimentary Research 81, 702-707. https://doi.org/10.2110/jsr.2011.55. 


\title{
Chapter 2
}

\section{Paleohydrology and Machine-assisted Estimation of Paleogeomorphology of Fluvial Channels of the Lower Middle Pennsylvanian Allegheny Formation, Birch River, WV}

\author{
Oluwasegun Abatan', Amy Weislogel ${ }^{1}$ \\ ${ }^{1}$ Department of Geology and Geography, West Virginia University, Morgantown, WV, United \\ States \\ * Correspondence: \\ Amy Weislogel \\ amy.weislogel@mail.wvu.edu
}

Keywords: Fluvial1, Paleohydrolgy2, Sedimentology3, Allegheny4, Source-to-Sink5, MachineLearning6.

Submitted to Frontiers in Earth Science Journal

Status of submission - Accepted for publication 


\section{$1 \quad$ Abstract}

Rivers transport sediments in a source to sink system while responding to allogenic controls of the depositional system. Stacked fluvial sandstones of the Middle Pennsylvanian (Desmoinesian Stage, 310 - $306 \mathrm{Ma}$ ) Allegheny Formation (MPAF) exposed at Birch River, West Virginia exhibit change in sedimentary structure and depositional style, reflecting changes in allogenic behavior. Paleohydrologic and numerical analysis were used to quantify geomorphological and paleohydrologic variations reflected by MPAF fluvial deposits with the goal of understanding the controls on resulting fluvial sandstone architecture in these different systems. Channel body geometry, sedimentary structures, and sandstone grain size distribution were used to reconstruct the paleoslope and flow velocity of the MPAF fluvial systems. In order to enhance paleohydrological estimates, machine learning methods including multiple regression and support vector regression (SVR) algorithms were used to improve the dune height, and channel depth estimated from cross-set thickness. Results show that the channel depths of the lower MPAF beneath the Lower Kittanning coal beds tend to decrease upsection; this decrease is interpreted to reflect a transition from fluvial systems formed in a humid ever-wet climate to fluvial systems formed in less humid, seasonally wet, semi-arid climate. Paleohydrologic estimations enabled the evaluation of hydraulic changes in the fluvial depositional systems of the Appalachian Basin during the Desmoinesian stage. Paleoslope estimates indicated that the slope was low, which indicated that the fluvial gradient response was not driven by the effect of tectonic subsidence or uplift and sea-level change.

\section{Introduction}

Fluvial systems are the main terrestrial conduits for transporting the sediment load of a source to sink system. The source to sink system involves source rock erosion in the initial catchment area and sediment transportation through fluvial environments and to ultimate deposition in a basinal sink (e.g., Bhattacharya et al., 2015; Lin and Bhattacharya, 2017). The fluvial system responds to external factors, such as climate, tectonics, and eustasy and is driven to maintain equilibrium while efficiently routing sediments. Changes in fluvial hydrology lead to changes in sediment transport and deposition, which alter channel aggradation, channel incision and channel morphology (Leeder, 1993, 2009; Holbrook and Wanas, 2014). For example, fluvial channels in seasonal semi-arid climates have different geomorphology and hydrologic processes from fluvial channels of ever-wet humid climates (Fielding et al., 2009; Allen et al., 2014; Plink-Björklund, 2015). Modern fluvial depositional system analogs indicate that fluvial systems in seasonal semi-arid climatic regions typically have a greater channel width to depth ratio than fluvial channels of everwet humid climatic region (Fielding et al., 2009; Gibling et al., 2014).

Channel depth and width data combined with sedimentologic data from outcrop can be used to estimate paleohydrology for ancient fluvial systems (Rubin and McCulloch, 1980; Bhattacharya et al., 2015), which can then be tied to climate controls. Improved knowledge of the relationship between paleohydrology and depositional products of fluvial systems can also be used to improve reservoir characterization and reservoir quality prediction. In particular, the continuity and quality of fluvial sandstone reservoirs are dependent on the channel style of the fluvial depositional system (Miall, 1996; Bridge, 2009). Fluvial systems with high net-to-gross sandstone ratios form reservoirs with higher quality compared to fluvial systems with abundant overbank fine-grained sediments. Braided fluvial systems produce laterally continuous sandstone bodies with sheet geometries, while sinuous fluvial systems (meandering or anastomosing) produce laterally restricted sandstone bodies with ribbon and lens geometry (Miall, 1996). Braided channels have higher flow velocities because 
they are formed in areas with high slope, whereas sinuous fluvial system has relatively lower velocities because they are formed in areas with relatively lower slope (Schumm, 1981; Miall, 1996).

This paper proposes an enhanced methodology with which to estimate the paleohydrology and paleo-geomorphology of fluvial channels, using the fluvial sandstone deposits of the lower part of the Middle Pennsylvanian Allegheny Formation (MPAF) of Central West Virginia as a case example (Figure 2-1 and Figure 2-2). The MPAF is characterized by repetitive cycles of clastic and chemical sediments known as cyclothems (Cecil, 1990). The MPAF at the Birch River area central West Virginia lacks marine zones where it is well exposed along a continuous road cut approximately $110 \mathrm{~m}$ high and $500 \mathrm{~m}$ long along US 19 as it crosses Powell Mountain near Birch River in central West Virginia (Figure 2-1). The lower part of the Middle Pennsylvanian Allegheny Formation (from here on referred to as MPAF) includes sandstones overlying the Lower Kittanning coal beds, the Upper No. 5 Bock coal beds and the No. 5 Block coal beds (Figure 2-2 and Figure 23 ). Facies analysis determined channel style and geometry of the lower MPAF sandstones and revealed a range of channel forms, including high sinuosity, low sinuosity and braided. This interval was selected for paleohydrological analysis because previous coal paleobotany studies indicate fluctuation between a humid and a seasonally wet-dry climate during MPAF deposition (Cecil, 1990; Eble, 2002; Cecil et al., 2003; Falcon-Lang, 2004; Greb et al., 2008, 2008; Falcon-Lang and Dimichele, 2010), and, thus, provides important independent constraints on paleoclimate variability with to investigate fluvial system response to paleohydrological controls. 


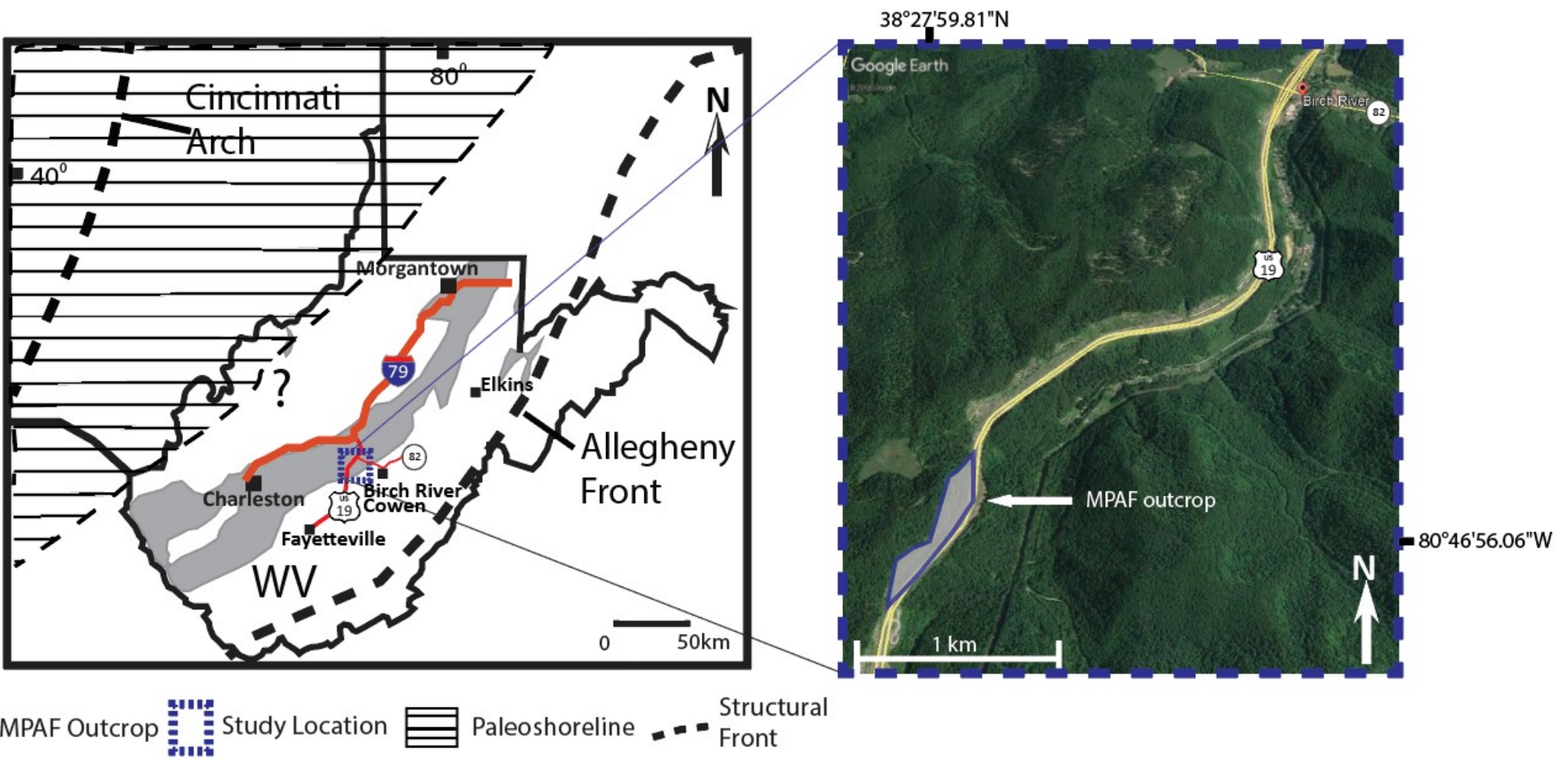

Figure 2-1: Study location, Birch River, West Virginia. The gray fill is the MPAF outcrop belt, WV. The dashed Square is the outcrop location. 
(A)

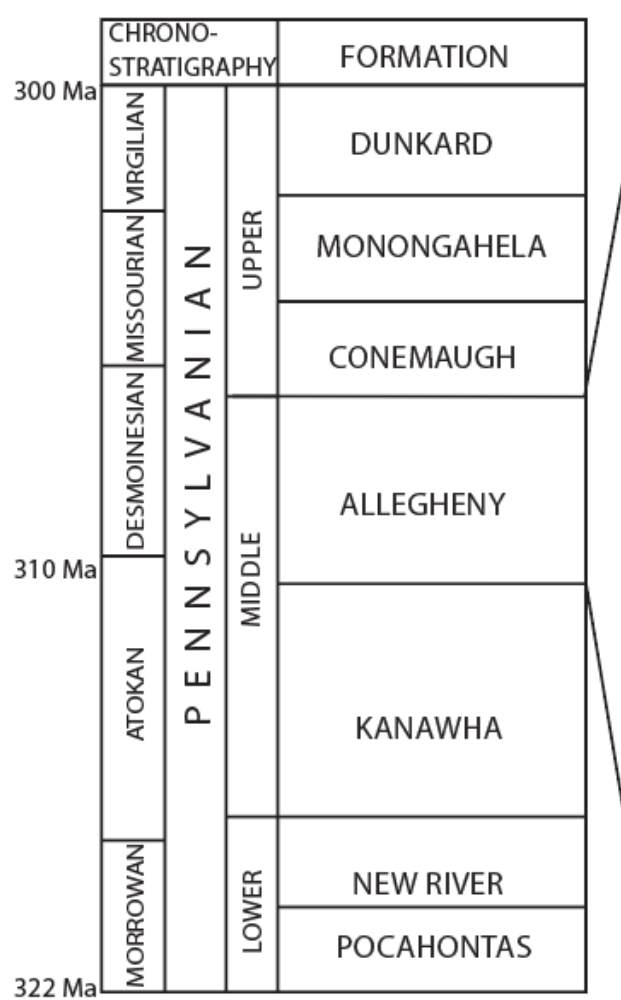

Lithology

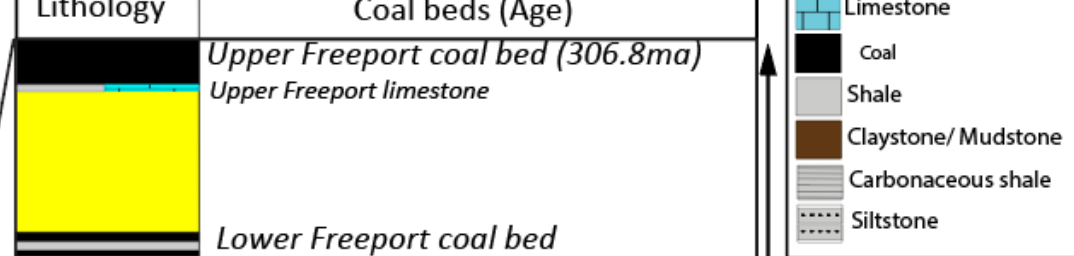

$====$

Lower Freeport coal bed

Lower Freeport limestone

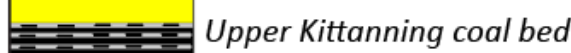

Johnstown limestone

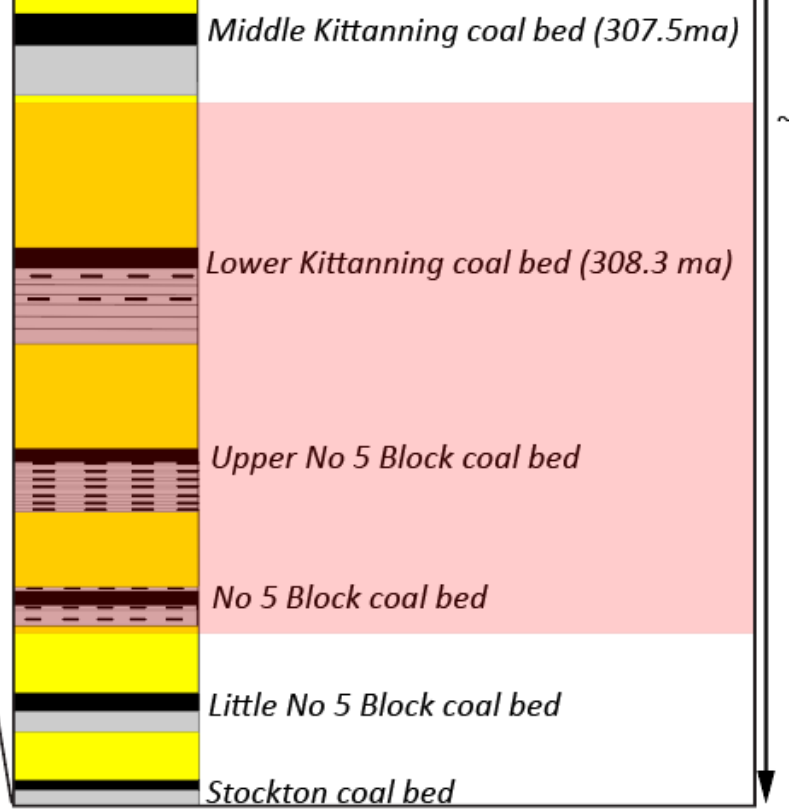

Key

.... Coal clast

Rip-up clast

0000 Siderite/ Ironstone nodules

Trough cross stratification Convex upwards sheets

Low angle cross

stratification

Planar cross stratification

Elanar stratification

- Ripple stratification

Inclined beds

Deformed bed

Root features

Plant fossil/ trash (branches,

leaf etc) 


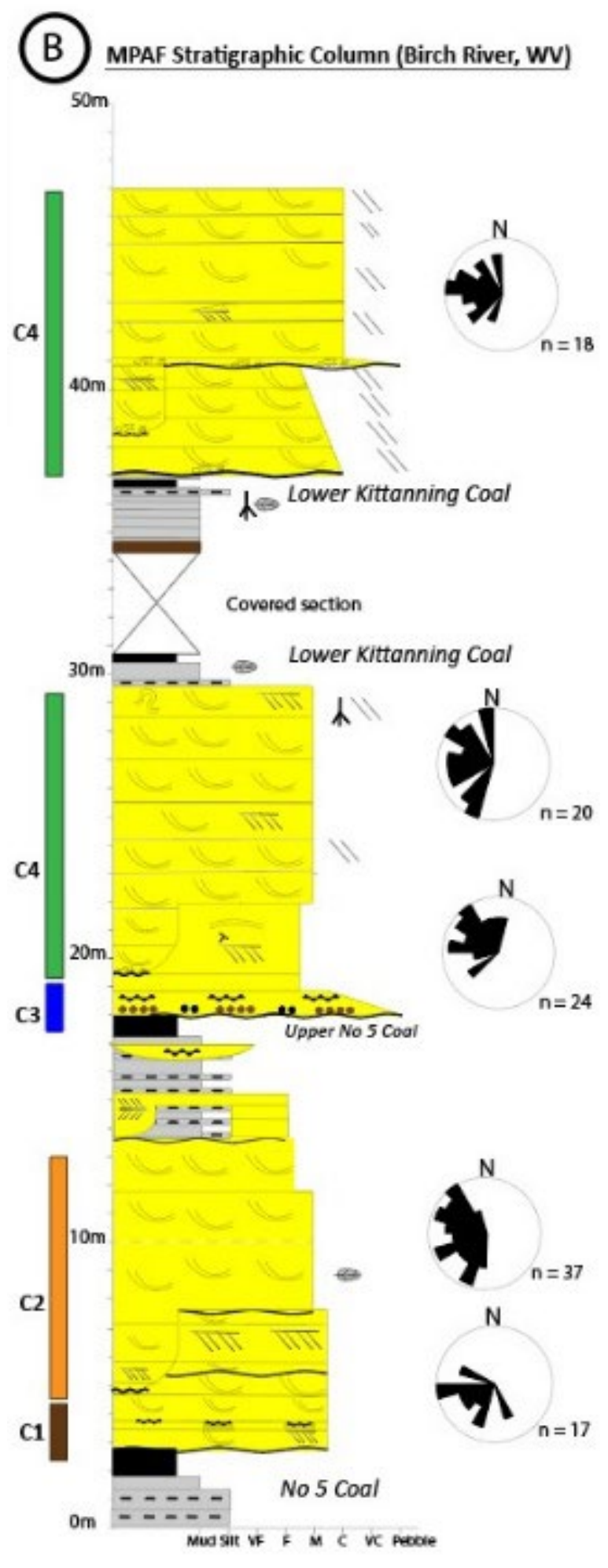

Figure 2-2: Lithologic Column (Not drawn to scale) and stratigraphic column of the Middle Pennsylvanian Allegheny Formation (MPAF). A) Lithologic column. Study interval includes No. 5 Block, Upper No.5 Block, and Lower Kittanning coal beds and associated clastic deposits (Shaded square). B) Stratigraphic column of the MPAF, Birch River, West Virginia. The lithologic column was modified from Blake et al. (2002) and Cecil et al. (2004). Coal age was from Montañez et al. (2016). 

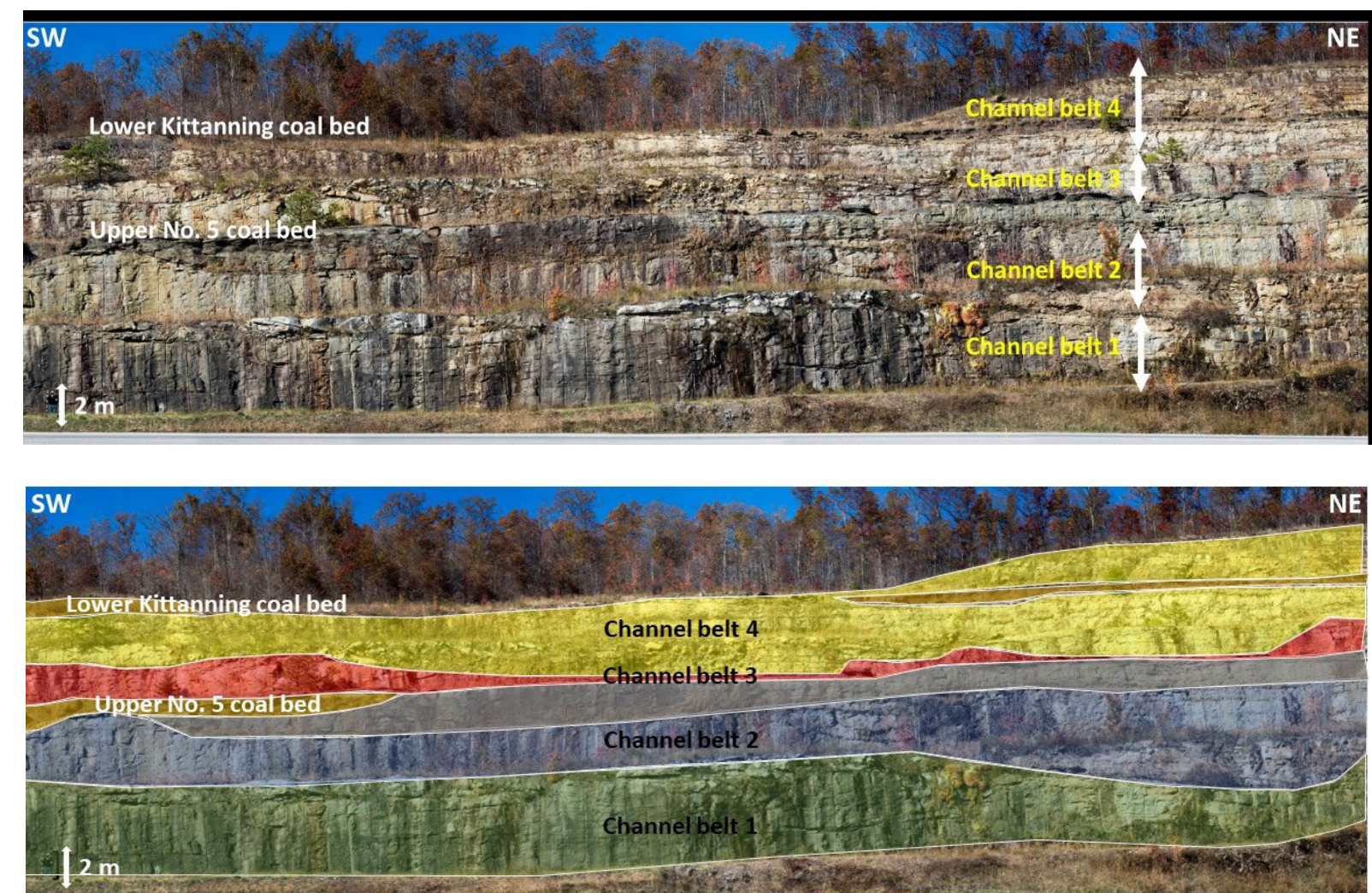

Channel belt 1 - Low sinuosity river deposits

Channel belt 2 -Braided channel deposits

Coal beds and floodplain deposits

Channel belt 3 - High velocity flow channel deposit

Channel belt 4 - Sinuous channel deposit

Lake deposit

Figure 2-3: The Middle Pennsylvanian Allegheny Formation outcrop, Birch River, West Virginia. A) Outcrop with scale (White bar), the position of coal beds and channel belt locations. B) Birch River outcrop with interpreted channel belt boundaries. 
Fluvial paleohydrology can be modeled from numerical equations based on grain size along with channel depth and width measurements and augmented by flow depth estimates from estimated dune bedform height (Ethridge and Schumm, 1977; Bridge and Tye, 2000; Leclair and Bridge, 2001; Leclair, 2002; Bhattacharya et al., 2015). These empirical equations relate sandstone grain size and channel geometry to estimates of paleohydrology. To build upon previous attempts at reconstructing paleohydrology of ancient fluvial systems, machine-assisted algorithms were developed to improve the accuracy of the estimated dune height from cross-set thickness using data of cross-set thickness and dune height from flume experiments reported by Leclair (2002) and Leclair and Bridge (2001). Multi-variate regression analysis was performed on the original data set to highlight the statistical significance ( $p$-value) of the relationship between the variables in the data set. Support vector regression algorithm (herein and after referred to as SVR) was selected to better assess the relationship between variables with acceptable statistical significance (i.e. p-value $<0.05$ ) because it can be used where bivariate relationships are established between geological properties with multivariate relationships (Ethridge and Schumm, 1977; Davis and Sampson, 1986; Bridge, 2009). Through this approach, the paleohydrological controls on MPAF fluvial architecture can be assessed to provide insights into the evolution of fluvial style and fluvial basin-fill record of the Alleghany foreland basin.

\section{Geological Setting}

\subsection{Geologic History}

The Middle Pennsylvanian (Desmoinesian Stage, 310 - $306 \mathrm{Ma}$ ) Allegheny Formation (MPAF) is part of an Upper Paleozoic cratonward prograding clastic wedge shed from the adjacent orogenic highlands of the Allegheny orogeny during the late Middle Pennsylvanian (Arkle Jr et al., 1979; Donaldson and Shumaker, 1981; Ettensohn, 2008). The collision of Laurasia and Gondwanaland ( $325 \mathrm{Ma})$ initiated the Alleghenian orogeny, which was characterized by collision and compressional deformation structures that formed the Allegheny fold-thrust belt (Donaldson and Shumaker, 1981; Ettensohn, 2005, 2008; Sak et al., 2012). The Alleghenian orogeny resulted in the formation of a broad shallower foreland basin than the Acadian and Taconic orogeny (Ettensohn, 2005, 2008). Paleoclimate models developed using coal beds, paleosol, soil carbonate-based, and fossil leaf-based proxies indicate that paleoclimate shifted from ever-wet humid to seasonally arid conditions during the Middle Pennsylvanian (Cecil et al., 2003, 2004; Tabor and Poulsen, 2008; DiMichele et al., 2010; Falcon-Lang and DiMichele, 2010; Montañez et al., 2016). In particular, palynomorph studies of the MPAF showed tree ferns, which are common in less humid environments, increased and became more common in No. 5 Block and Upper No. 5 Block coal beds sections of the MPAF, whereas lycopsids, which are common in very humid environments, dominated the Lower Kittanning coal bed (Kosanke and Cecil, 1996; Eble, 2002; Falcon-Lang and Dimichele, 2010).

The major driver of the paleoclimate change was attributed to the low paleo-latitudinal position of the Appalachian Basin during Middle Pennsylvanian; and the effect of glacial volumes at the poles on Hadley Cell circulation patterns along the Intertropical Convergence Zone (ITCZ) (Cecil and Dulong, 2003; Cecil et al., 2004). Changes to the Haley Cell circulation patterns along the ITCZ resulted in the seasonality of rainfall in low latitudes during glacial minimum and high rainfall during glacial maximum. The development of a rain shadow on the Alleghenian foreland basin, which is located on the downwind side of the orogenic highlands, may have also contributed to the drier climate (Tabor and Montanez, 2002; Tabor and Poulsen, 2008). Paleobotanical and sedimentologic studies indicate that earlier MPAF depositional systems formed in a humid climate, while the MPAF 
above the Lower Kittanning coal beds where deposited in a semi-arid climate (Cecil, 1990; Cecil et al., 2003; Greb et al., 2008; DiMichele et al., 2010; DiMichele, 2013; Montañez et al., 2016). Paleogeographic reconstructions of the North American craton suggest that the Appalachian basin was near the paleo-equator with Appalachian highlands to the northeast and coastal lowlands located to the west (Archer and Greb, 1995; Cecil et al., 2004). The resulting paleo-gradient resulted in south and western drainage directions (Donaldson and Shumaker, 1981; Cecil et al., 2003, 2004). Paleodrainage models based on sedimentary analysis indicate the MPAF clastic wedge is composed of swamp, lacustrine, fluvial and deltaic deposits (Donaldson and Shumaker, 1981; Cecil, 1990). Marine fossils observed in MPAF sandstones suggest the downdip extent of the fluvial segments of the MPAF prograding clastic wedge is located in southeast Ohio (Stubbs, 2018).

\subsection{MPAF Channel Belts, Birch River, WV}

The MPAF clastic units are subdivided based on coal beds, which stratigraphically oldest to youngest include: No.5 Block, Upper No.5 Block, Lower Kittanning (No. 6 Block Coal), and Middle Kittanning coal beds (Arkle Jr et al., 1979; Blake et al., 2002; Eble, 2002). Palynomorph studies found that more lysosomes (fungi) spores, which are common in humid ever-wet environment are more abundant in early Middle Pennsylvanian deposits below the MPAF, whereas herbaceous fern plants, which are common in less humid environments, were more abundant in late Middle to early Upper Pennsylvanian deposits (Cecil et al., 1985; Kosanke and Cecil, 1996; Peppers, 1996; Eble, 2002). Sedimentologic models used lithologic climate indicators such as presence of caliche, calcareous pedogenic concretions, and siderite to assess climatic fluctuations during the Pennsylvanian, including parts of the upper MPAF which includes the Middle Kittanning, Upper Kittanning, Lower Freeport, and Upper Freeport coal beds and their associated clastic deposits (Donaldson and Shumaker, 1981; Cecil et al., 1985; Cecil, 1990; Cecil and Dulong, 2003). 


\section{$4 \quad$ Methods}

\subsection{Facies Architecture of the MPAF Channel Belts}

Facies associations and architecture were used to interpret the fluvial styles (Miall, 1996; Bridge, 2009). Facies and facies association were identified from a $45 \mathrm{~m}$ thick and $495 \mathrm{~m}$ wide outcrop (Miall, 1996; Bridge, 2009). Data were measured using a Wentworth calibrated grain-size card, measuring staff and ruler. Paleocurrent data were acquired from the left and right limbs of trough cross-strata using the best-fit circle method to determine paleocurrent direction on a stereographic plot (DeCelles et al., 1983).

\subsection{Paleochannel Geometry Measurements and Estimation}

Sedimentological data for the study was acquired from road cut (outcrop) along Route 19, Central West Virginia (Figure 2-1 and Figure 2-3). Units of MPAF present at Birch River outcrop include the No. 5 Block coal bed, the Lower Kittanning coal (LKC) bed, shale and sandstone units above and below No. 5 Block, the Upper No. 5 Block and LKC coal beds ( Blake et al., 2002; Cecil et al., 2004; Eble, 2002) (Figure 2-1 and Figure 2-2). Sedimentologic data acquired from the outcrop includes grain size, cross-bedding height, and barform height. These data were used to determine channel geometry (width and depth) by the methods outlined below.

\subsubsection{Channel Depth}

Channels were measured from preserved paleochannel boundaries corrected for compression during burial. Channel depths that were estimated from bar height involved the measurement of fully preserved channel bars in outcrop (Allen, 1970; Lin and Bhattacharya, 2017). The thickness of lateral or downstream accretion bars from outcrop, adjusted for $10 \%$ compaction factor, is representative of the bankfull channel depth (Ethridge and Schumm, 1977; Davidson and Hartley, 2010). The thickness of lateral or downstream accretion bars was determined using the fining upward sequence concept, where the lower and mid-section of the bar is characterized by planar, trough cross, planar cross and inclined bedded sandstone that is relatively coarser than the upper section of the bar, which is characterized by massive and ripple bedded sandstone with plant debris and/ or rooting structure (Bridge and Tye, 2000). The paleochannel flow depth was estimated from the thickness of lateral or downstream accretion macroforms using the equation by Ethridge and Schumm (1977):

$$
d=D^{*} / 0.9
$$

Where $\mathrm{D}^{*}$ is maximum channel depth, which is represented by the thickness of the sandstone macroform, 0.9 compensates for the compaction factor. Errors associated with this method can be up to $100 \%$ if it is used for muddy sections (Holbrook and Wanas, 2014).

Channel depths were also estimated from dune-scale cross-set thickness, using empirical equations and machine-assisted algorithms. Previous work developed empirical equations which have been applied in the estimation of paleochannel dimension and morphology for ancient fluvial channel deposits. These equations determined relationships between the mean value of the exponential tail of the Probability Density Function (PDF) for cross-set thicknesses and dune heights (Leclair and Bridge, 2001). The work by Leclair and Bridge (2001) has shown that the dune height $\left(\mathrm{h}_{\mathrm{m}}\right)$ can be estimated from mean cross-set thickness $\left(\mathrm{S}_{\mathrm{m}}\right)$ using a regression equation:

$$
h_{m}=5.3 \beta+0.001 \beta^{2}
$$




$$
\beta=S_{m} / 1.8
$$

Which can be simplified as:

$$
h_{m}=2.9 S_{m}
$$

Where $h_{m}$ is the mean dune height, $S_{m}$ is the mean cross-set thickness, $\beta$ is the mean value of the exponential tail of the probability density function for topographic height relative datum. The range of error in this empirical equation is $\sim 20 \%$ (Leclair and Bridge, 2001). Hence the authors suggest the equation be used on data set with similar standard deviation. Based on the observation that the ratio of bankfull depth to dune height is commonly between 6 and 10 (Bridge and Mackey, 1993; Bridge and Tye, 2000), dune height $\left(h_{m}\right)$ can be used estimate channel bankfull flow depth $(d)$ :

$$
6<d / h_{m}<10
$$

\subsubsection{Machine-Assisted Estimation of Channel Belt}

A support vector machine regression algorithm was developed to generate a new empirical equation that relates preserved cross-set thickness to dune height to improve channel depth estimates from cross-set thickness. These relationships were established from measurements of dunes, and corresponding cross-set geometry produced under known hydrological conditions of a flume. First, multiple regression analysis using least squares elimination method was applied to the data set of Leclair (2002), which includes measurements of flow conditions and resulting bedform and cross-set heights, in order to determine the statistical relationship between dune heights and cross-set thicknesses.

\subsubsection{Multiple Regression Analysis}

This study employs multiple regression to highlight the relationship between all the variables measured in flume studies that were used to explain the relationship between cross-set thickness and dune height (Leclair, 2002). The equation used for multiple regression is given as:

$$
Y=\beta_{0}+\beta_{1} X_{1}+\beta_{2} X_{2}+\cdots+\beta_{n} X_{n}+\varepsilon
$$

Where $\mathrm{Y}$ is the dependent variable represented as cross-set thickness, $\beta_{0}$ is the intercept, $\beta_{n}$ are the coefficients, $X_{n}$ are the independent variables describing flow conditions and depositional products, and $\varepsilon$ is the random error. The accuracy of the multivariate regression was scored using $\mathrm{R}^{2}$. Then, SVR was applied to create and improve empirical relationships between the variables with the highest level of statistical significance as determined from the multiple regression analysis.

\subsubsection{SVR Analysis}

Support vector regression (SVR) is a type of supervised machine learning algorithm that fits as many instances in the model by taking into consideration the outliers in the dataset while developing an empirical relationship. The SVR machine learning model was selected because it performs linear or non-linear regression in a higher-dimensional space using linear, polynomial or Gaussian kernels. The kernels transform the data into a higher-dimensional space by creating a vector from the evaluation of the test positions of all the data and establishes a linear, polynomial or Gaussian relationship amongst the variables in the data. The Gaussian kernel uses normal distribution curves around data points to try to establish a relationship with the variables being considered. The 
advantage of SVR over linear regression is that SVR allows the model to be less fitted to the training data but more flexible for predicting new data (Zhang et al., 2014). SVR can also be used for multivariate regression, hence new variables can be added to try to improve predictions. The simplified equation for predicting the dependent variable (Y) using the SVR model (Bao and Liu, 2006; Awad and Khanna, 2015) is given by:

$$
Y=w^{T} \phi(x)+b
$$

Where $Y$ is the dependent variable, $\boldsymbol{w}=\left(w_{0}, w_{1}, w_{2}, \ldots\right)^{T}$ is the fitting coefficient in the higher dimensional space, $\phi$ is the kernel function transforming the independent variable $\boldsymbol{x}$ (cross-set thickness in this paper) to a higher dimensional feature space, and $b$ is the intercept. The model's performances compared to the previously used empirical equation (Equation 2) were evaluated by testing the accuracy of the model's predictions using mean square errors. Grid search algorithm was used to determine the best penalty parameter (C), fitting error $(\xi)$ and the kernel line of best fit for the data. Details of the algorithm and selected parameters to develop the SVR model are in the supplemental data. Algorithms for the SVR was written using Python and scikit-learn libraries (Pedregosa et al., 2011). The steps taken to derive the SVR model for predicting dune height from cross set thickness include data preprocessing, kernel and parameter selection, and model fitting (Figure 2-4).

\subsection{Data Preprocessing}

This includes sorting of the independent variable from lowest to highest value and normalizing the data. The cross-set thickness was set as the independent variable, while the dune height was set as the dependent variable for the SVR model. The cross-set thickness data was sorted and both data set were normalized. Normalization removes any disparity in the model that may be due to different units of measurements and large variance between values in the data that might skew the regression model in favor of the data set with larger values. The normalization of the independent and dependent variables involved adjusting both data set to a common scale. The normalization method used was MinMaxScaler, which has the ability to scale the data set between any range of values stipulated. The data was scaled into values between 0 and 1 using methods described in Pedregosa et al. (2011).

\subsection{Kernel and Parameter Selection}

Grid search was used to cross-check all kernels and parameters until there was convergence i.e the ideal kernel and parameters that will give the best solution are determined. Kernel is a weighing factor between two sequences of linear and/ or non-linear data, which enables the correlation of the data set in higher dimension space (Pedregosa et al., 2011). Three types of kernel considered are linear, polynomial and Gaussian kernels. The parameters considered include gamma, $\mathrm{C}$ and epsilon $(\xi)$. The gamma parameter defines how far the influence of a single training example reaches and can be seen as the inverse of the radius of influence of samples selected by the model as support vectors (Pedregosa et al., 2011). The gamma range considered was from $0.5-0.8$. The $\mathrm{C}$ parameter trades off correct classification of training examples against maximization of the decision function's margin., hence the $\mathrm{C}$ parameter behaves as a regularization parameter in the SVM (Pedregosa et al., 2011). The range of $C$ parameters considered was from $0.1-100$. The epsilon defines a margin of tolerance where no penalty is given to errors (Pedregosa et al., 2011). The larger epsilon is, the larger errors you admit in your solution. The epsilon range considered was from $0.01-0.5$. The gamma, $\mathrm{C}$ and epsilon values, $0.8,10$ and 0.01 respectively, were selected because they produce they produced 
the best SVR model. The accuracy score of the SVR model from the using the Gaussian kernel and selected parameters $0.8,10$ and 0.01 for gamma, $\mathrm{C}$ and epsilon values respectively, is $84 \%$.

\section{Data}

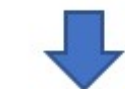

\section{Data}

\section{Preprocessing}

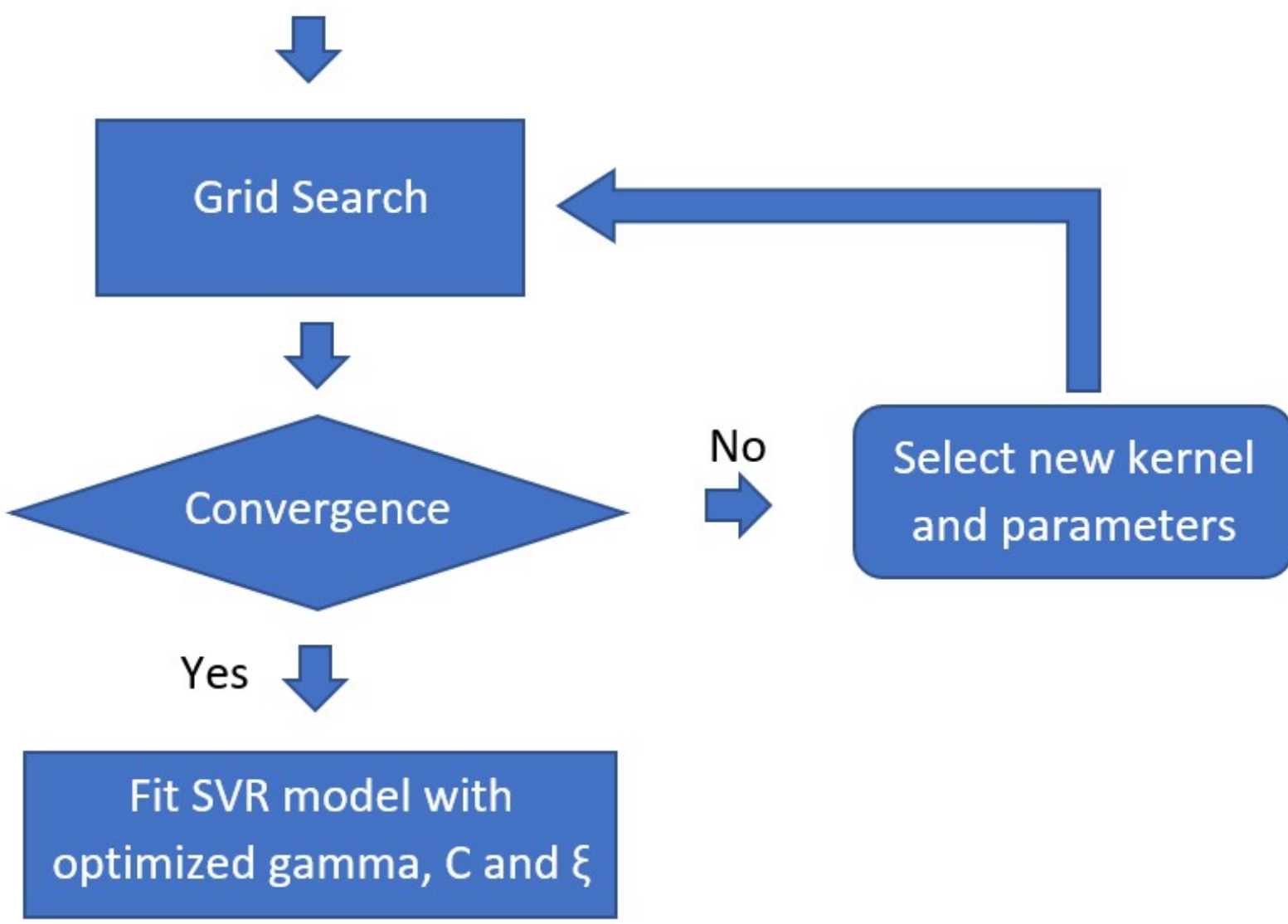

Figure 2-4: Workflow for Support Machine Regression (SVR) analysis.

\subsection{SVR Model Fitting}

SVR model is fitted to the data set using the kernel and parameters from the grid search analysis. The model can be used to predict the dune height from cross-set thickness data inputted into 
the model. An inverse normalization is used to revert the normalized data and normalized model prediction.

\subsubsection{Channel Width}

Full channel widths were determined from Channel belt 1. Full channel belt widths could not be determined from the other channel belts because of the erosive nature of the channel boundaries. True channel width was derived from apparent channel widths measured from Channel belt 1 by correcting for the orientation of the MPAF outcrop and paleoflow direction. Channel width was also estimated using published scaling relationships for channel geometry that takes into consideration the channel style as well as the tectonic and climatic setting of the fluvial systems (Gibling, 2006; Blum et al., 2013). The common range of channel width to depth scaling ratios selected from Gibling (2006) includes 5 - 50 for fixed river systems, which were used in channel belt 1, 50-1000 for braided and low-sinuosity rivers used for channel belt 2 and channel belt 3, and $30-250$ for Channel belt 4 .

\subsection{Paleoslope}

Paleoslope was estimated using grain size and density of sediment grains following the empirical equation of Holbrook and Wanas (2014):

$$
\tau_{b f 50}^{*}=\left(d_{m} S\right) /\left(R D_{50}\right)=\text { constant }
$$

Where $\mathrm{S}$ is slope, $\tau^{*}{ }_{\mathrm{bf5}}$ is the bankfull Shields number for dimensionless shear stress, $\mathrm{d}_{\mathrm{m}}$ is the mean bank full flow depth, $\mathrm{R}$ is submerged dimensionless density of sand-gravel sediment (qs - qw), and $\mathrm{D}_{50}$ is median grain size. $\tau^{*}{ }_{b f 50}$ is assumed to be 1.86 after Holbrook and Wanas (2014).

Grain size for this study was quantified from thin-section petrography, as well as estimated from observations of rocks in outcrop using a grain size card with graphical representation of Wentworth grain size classes. The error in grain size made from grain size cards have an error of about $1 / 2$ phi (Lin and Bhattacharya, 2017). Four thin sections were selected that were representative of average flow in the 4 fluvial channel types interpreted in the lower MPAF. The thin-sections were acquired from above the scour deposits, which should be representative of deposits of moderate flow conditions. For each thin section, the maximum axis of at least 100 grains was measured and used to calculate median grain size $\left(D_{50}\right)$ for use in the empirical equation to estimate the paleoslope for MPAF paleochannels (Holbrook and Wanas, 2014).

\subsection{Paleohydrology}

Channel dimensions and paleoslope combined with flow velocity permit paleohydrologic reconstruction of MPAF channels using channel width derived from scaling factors to account for variabilities in channel cross-sectional area due to the depositional environment. Paleodischarge was estimated using the continuity equation (Equation 9):

$$
\boldsymbol{Q}=\boldsymbol{V A}
$$

Where Q is instantaneous discharge and A is cross-section area, which is the product of channel width and depth. Flow velocity was estimated by using sedimentary structures to infer the bedform for comparison with the bedform phase diagram of Rubin and McCulloch (1980). The dominant 
bedform observed in the channel belts were used to estimate flow velocity under the assumption that the dominant bedform reflects dominant bedload transport conditions during flooding events (Bhattacharya et al., 2015; Lin and Bhattacharya, 2017). The cross-sectional area was derived from estimated depth using the SVR machine-assisted model and width from width to depth scaling the relationship of modern and ancient fluvial channels (Gibling, 2006). We elected to not use empirical equations to estimate channel width from channel depth estimates, as this approach does not consider channel style as a variable in constraining channel width.
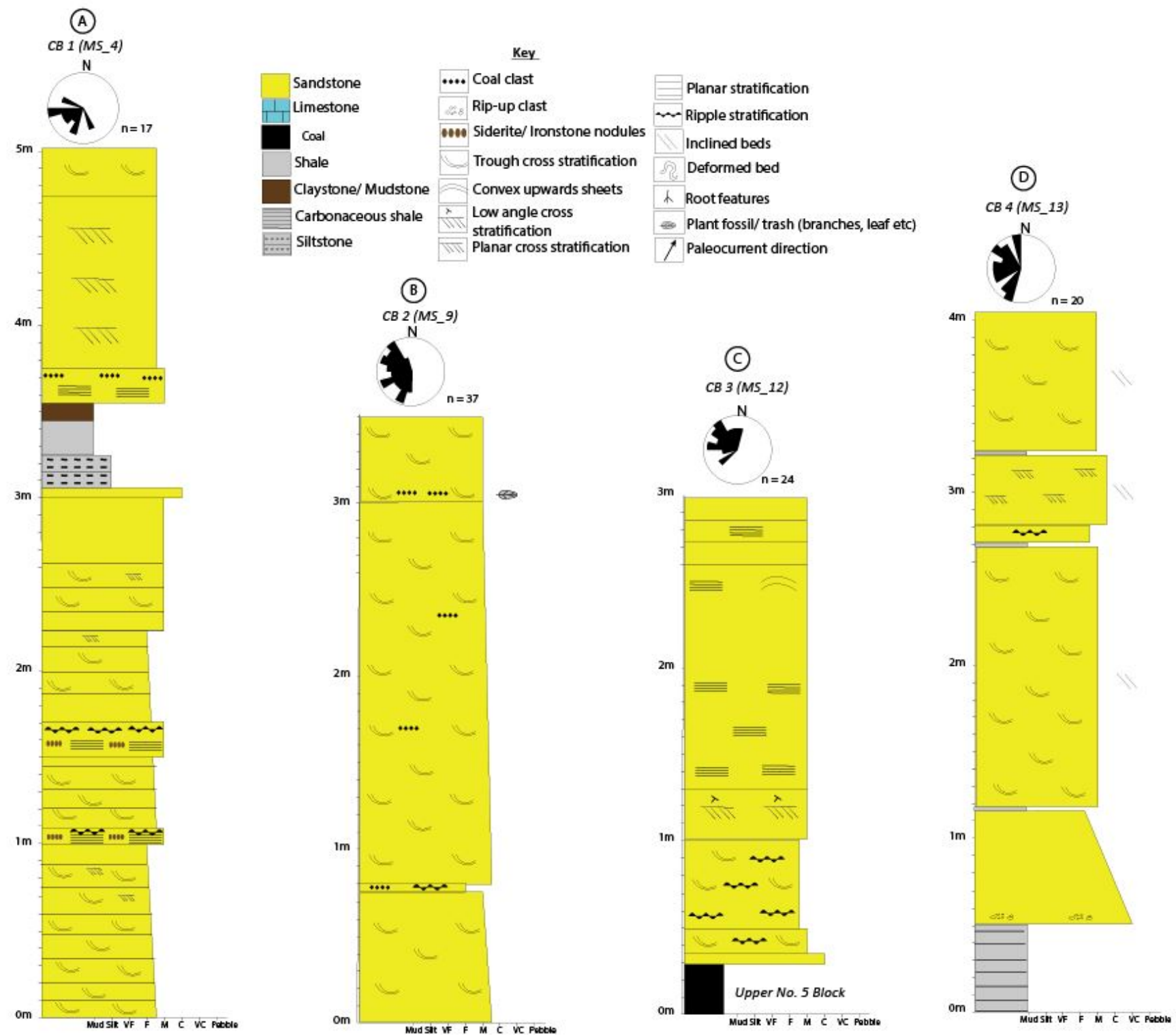

Figure 2-5: Measured sections of channel belt 1 to 4 showing key depositional facies and paleocurrent data. A) Channel belt 1 (CB 1) represents low sinuosity channel deposits. B) Channel belt 2 (CB 2) represents braided channel deposits. C) Channel belt 3 (CB 3) represents high velocity channel deposits. D) Channel belt 4 (CB 4) represents channel sinuous channel deposits.

\section{$5 \quad$ Results}




\subsection{MPAF Channel Belts}

Facies and facies architectural analysis revealed nine lithofacies that represented fluvial channel deposits. The channel lithofacies include horizontally-stratified sandstone, ripple-stratified sandstone, poorly sorted sandstone, planar cross-stratified sandstone, trough cross-stratified sandstone, massive sandstone, and low angle cross-bedded sandstone or convex upward sandstone, laminated mudrock, and massive mudrock facies (Figure 2-5). The coal beds overlie mudrocks and non-channel sandstones. We categorize the fluvial channel deposits into channel belts based on the channel planform.

\subsubsection{Channel Belt 1: Low sinuosity fluvial system}

Channel belt 1 is made up of multiple stories up to $10 \mathrm{~m}$ thick of tabular and lenticular, fine to medium-grained sandstones with sharp, sub-horizontal to horizontal, undulating erosional basal contact and sharp, curved erosional bounding surface above (Figure 2-5). Channel belt 1 overlies the No. 5 Block coal bed (Figure 2-2). Five stories were identified in channel belt 1. Individual stories are characterized by multiple sandstone bed sets, which may be capped by mudrock, and are bounded above and below by an erosional surface. The two bottom stories are made up to $3 \mathrm{~m}$ thick lenticular sandstone separated by a sharp near-horizontal erosional surface. The lenticular sandstones comprise of convex upwards, fine to medium-grained, massive (Sm) and trough cross-stratified (St) sandstone with sharp, curved bedding plane at the base. The massive and trough cross-stratified sandstone beds are overlain by horizontal laminated sandstone (Sh) beds with a sharp horizontal bedding plane. The Sh is either onlapped by Sm or St beds with sharp, horizontal, or curved bedding planes. The Sm, St and onlapped Sh beds are overlain by St and Sp beds with sharp horizontal bedding plane. The Sh may be overlain by interlaminated claystone, siltstone and poorly sorted, ripple laminated sandstone in some places. The Sh may be overlain by interlaminated claystone, siltstone and poorly sorted, ripple laminated sandstone in some places.

The 3 upper stories are made up of up to $2 \mathrm{~m}$ thick tabular sandstone bounded below by nearhorizontal erosional surfaces. The tabular sandstones are made of tabular, fine to medium-grained trough cross and planar cross-stratified (Sp) sandstones with sharp, horizontal bedding plane. The Sp overlies the St in the tabular sandstone. The Sp may be overlain by horizontal laminated sandstone beds in some places. The Sp beds are up to $1 \mathrm{~m}$ thick in some places. The uppermost tabular sandstone is erosionally truncated and overlain by sandstones from channel belt 2 . The sandstone of channel belt 1 contains abundant coal and siderite intraclast, and fossilized plant fragments. Channel belt 1 overlies the No. 5 Block coal bed. Paleocurrent data from trough cross-bedded sandstone indicate northeast to southwest direction of paleoflow. The lenticular sand bodies, which are overlain by Sh and onlapped by Sm and or St beds, are interpreted as mid-channel bar deposits while the tabular sand bodies are downstream accretion compound strata (Miall, 1996). The lack of a lateral accretion bar suggests low translation by channel. The abundance of coal and siderite intraclast suggest abundant vegetation and wet environment common in distal coastal plain depositional environments (Miall, 1996; Allen et al., 2014). Combined these features suggest channel belt 1 are deposits of a distal, low sinuosity fluvial system.

\subsubsection{Channel Belt 2: Braided fluvial system}

Channel belt 2 is made up of up to $5 \mathrm{~m}$ thick, multistorey, amalgamated, medium-grained sandstone bounded above and below by sharp, undulating, horizontal and curved erosional surfaces. Three stories were identified based on discontinuous, sub-horizontal, basal erosional surface and 
channel lag deposits. Channel lag deposits, which comprise pebble size coal clast and iron-rich claystone clast and veins, were used to infer the base of the story where the basal erosional surfaces were not apparent. Individual stories are characterized by up to $0.3 \mathrm{~m}$ thick, amalgamated, mediumgrained, compound through cross-stratified (St) sandstone beds with sharp or gradational, horizontal or trough-shaped bedding plane. The St are rarely overlain by horizontal, fine-grained, ripple laminated sandstone ( $\mathrm{Sr}$ ) beds. Where the $\mathrm{Sr}$ is absent $\mathrm{St}$ may be overlain by up to $0.3 \mathrm{~m}$ thick, medium-grained, planar cross-stratified sandstone beds (Sp) or St. Channel belt 2 sandstones contain coal intraclast and petrified plant stems in places and is overlain by deltaic, lake and well-drained floodplain deposits. The deltaic deposits are characterized by coarsening upwards, interlaminated shale and very fine-grained sandstone, the lake deposits are characterized by laterally continuous, tabular, massive sandstone beds, while the well-drained floodplain deposits characterized by discontinuous, lens-shaped, coarsening upwards ripple laminated sandstone beds and laterally continuous interlaminated siltstone, mudstone, and shale, which are overlain by the Upper No. 5 Block coal bed. Paleocurrent data from the trough cross-stratified beds indicate both northwest and southwest paleoflow direction. However, the dominant paleoflow is towards the northwest. Neither lateral nor downstream accretion macroforms were observed in channel belt 2 . The abundance of compound trough cross-bedded facies suggests the system was dominated by $3 \mathrm{D}$ dunes. The presence of bed sets bounded by curved and/ or horizontal bedding planes and the absence of a clear macroform such as lateral or downstream accreting deposits suggest that channel belt 2 is dominated by compound bars common in braided channel fills (Miall, 1996; Bridge, 2009; Allen et al., 2014). Combined all these features lead to the interpretation of channel belt 2 as deposits of a braided fluvial channel.

\subsubsection{Channel Belt 3: High-velocity channel}

Channel belt 3 is characterized by a fine to medium-grained, single-story tabular sandstone body bounded above and below by erosional surfaces. The facies association of Channel belt 3 is made up of poorly sorted, planar cross-stratified, trough cross stratified, massive, horizontally stratified, low angle cross stratified and convex upward sandstone strata (Figure 2-5). This channel belt is composed of two distinct sandstone units: A lower unit dominated by interbedded poorly sorted and ripple bedded sandstone that is $0.5-1 \mathrm{~m}$ thick, and an upper unit dominated by sandstones with upper flow regime structures (Allen, 1982) such as horizontal and low angle cross stratified and convex upward sandstone (Miall, 1996; Fielding et al., 2009). In some areas, the lower sandstone unit has some trough cross-bedded facies at the base, which transitions abruptly into the poorly sorted ripple laminated facies locally. The low angle cross-stratified and convex upward facies are the most dominant bedform in this channel belt. Channel belt 3 overlies the Upper No. 5 Block coal bed. The abundance deposits with upper flow regime structures and the abrupt transition in facies succession suggest deposits by a high velocity flooding event therefore channel belt 3 deposits may be deposits of a high velocity channel. The presence of low angle cross-beds and convex upward strata suggest supercritical flow event (Bridge, 2009; Allen et al., 2014; Miall, 2014). The presence of very coarse horizontal, ripple and poorly sorted bedded sandstone is indicative of a fluvial system with substantial erosive power.

\subsubsection{Channel Belt 4: Sinuous meandering channel}

Channel belt 4 is characterized by fine to coarse-grained, multi-story inclined tabular and lenticular sandstone bodies bounded by sharp and erosional surfaces. A typical Channel belt 4 story is composed of poorly sorted sandstone, ripple stratified sandstone, planar cross-stratified sandstone, 
trough cross-stratified sandstone and massive sandstone facies (Figure 2-5). Each story has poorly sorted and massive sandstone beds overlying an erosional base. The poorly sorted and massive sandstone beds are overlain by inclined, trough cross and planar cross strata, which may be draped by ripple stratified sandstone locally. The sandstone bodies of channel belt 4 stack vertically and extends laterally to form lateral accretion bars. The lower bounding surface for this channel belt is undulating erosional. The upper bounding surface is covered by soil and vegetation in the study area. Three stories were identified in the study location. The deposits of the first story of Channel belt 4 are overlain by floodplain deposits characterized by laterally continuous carbonaceous shale and claystone. The floodplain shale and claystone are overlain by the Lower Kittanning coal bed (LKC). The Channel belt 4 sandstones below the LKC are deformed and have abundant root traces. The second and third stories do not have coal beds and are not deformed. The inclined geometry, vertical and lateral succession of massive, trough cross-stratified, planar cross-stratified and ripple laminated facies are lateral accretion (point bar) deposits, which are common in the sinuous meandering channel. This led to the interpretation of channel belt 4 sandstone bodies as deposits of a sinuous meandering fluvial channel system. The deformed sinuous channels were interpreted as water escape features caused by the oversaturation of the sinuous channel deposits (Plink-Björklund, 2015).

\subsection{Machine-assisted Approach to Dune Height Estimation from Cross-bed Height}

\subsubsection{Multiple Regression}

The machine-assisted model was developed using multiple regression analysis and the SVR algorithm on the flume experiment data used by Leclair and Bridge (2001) to derive the empirical equations. A p-value of 0.005 was selected to test the significance of the statistical relationship (Davis and Sampson, 1986). Backward elimination showed that dune height $\left(\mathrm{h}_{\mathrm{m}}\right)$, as well as the dune length $(\mathrm{lm})$ (i.e. the dune wavelength), had a high level of significance relationship (i.e. p-value < $0.005)$ with the cross-set thickness $\left(\mathrm{S}_{\mathrm{m}}\right)$. It is difficult to measure the length of dunes in ancient deposits hence the relationship between cross-set thickness and dune height was further analyzed using SVR with the goal of developing a more efficient model for predicting dune height from the cross-set thickness in ancient channel deposits. These results from the multiple regression analysis highlighted the statistical relationship between cross-set thickness and dune height.

\subsubsection{Support Vector Regression (SVR) vs. Polynomial Regression}

Dune height was set as the variable to be predicted from cross-set thickness (Figure 2-6) in order to compare SVR dune height predictions with the predictions from the empirical equation derived from polynomial regression (Equation 4; Leclair and Bridge, 2001). The SVR model was used to predict dune heights from cross-set thicknesses derived from the flume experiment that Leclair and Bridge (2001) used to develop a polynomial regression model for dune height prediction from cross-set thickness. The Gaussian kernel, which used normal distribution analysis on data points in order to highlight the best-fitted hyperplane in the dune heights and cross set thicknesses regression plot, produced the best predictions in the SVR model. The mean square error (MSE) and root mean square error (RMSE) was used to compare the accuracy of predictions from both methods. The RMSE of predicted mean dune height from using the Leclair and Bridge (2001) model (Equation 5) was $16.8 \mathrm{~mm}$, whereas the RMSE of predicted mean dune height from the SVR model was 9.3 $\mathrm{mm}$, indicating the SVR model estimates were closer to the actual dune height produced in the flume experiment. 


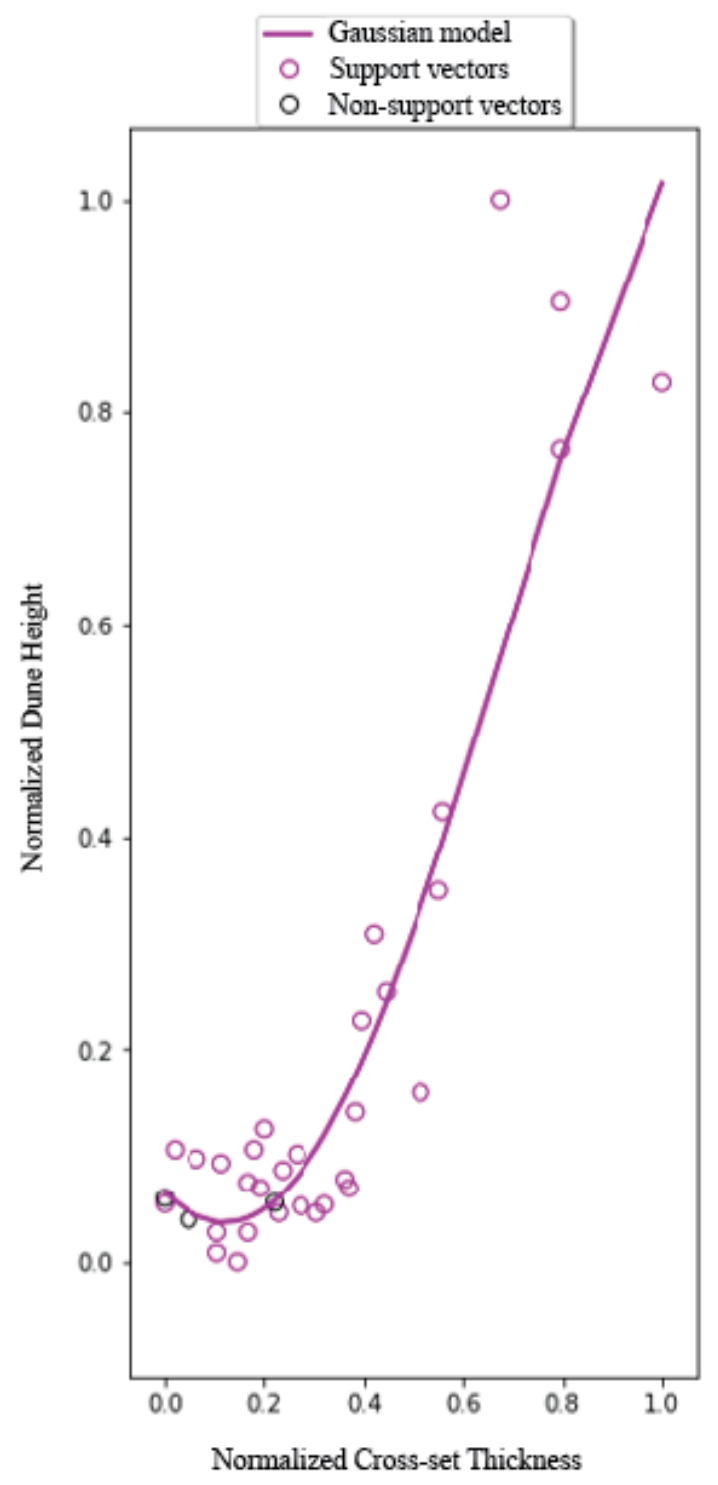

Figure 2-6: Variation of mean dune height (hm) and cross-set thickness (Sm), with a Gaussian kernel hyperplane. The support vectors are the data points used by the Gaussian kernel for plotting the bestfitted hyperplane for the regression analysis. Data sourced from LeClair (2002).

\subsection{Paleochannel Depth Estimates}

Paleochannel depth was estimated from measured bar thickness corrected for compaction in Channel belts 1 and 4 using Equation 1; however, only incomplete channel bars were observed in Channel belts 2 and 3. Measurements of these incomplete bars were recorded to constrain minimum paleochannel depth. Paleochannel depths estimates were also determined from dune heights predicted from cross-set thicknesses for all of the MPAF channel belts using Equation 5 (Bridge and Tye, 2000) (Table 2-2). Paleochannel depth was estimated from the dune height $\left(\mathrm{h}_{\mathrm{m}}\right)$ based on the observation that the ratio of bankfull depth to dune height is commonly between 6 and 10 (Bridge and Mackey, 1993; Bridge and Tye, 2000). Paleochannel depth estimated from cross-set thickness were recorded for individual channel stories in channel belt 1 and 4 (Table 2-2). Channel stories were 
not identified in Channel belt 2 and 3 because of the amalgamated nature of deposit from Channel belt 2 and the absence of Channel stories in Channel belt 3. Overall, depth estimated from cross-set thickness measurements is greater than those estimated from bar thickness, suggesting that the bars of the MPAF have been largely subjected to substantial erosional truncation (Figure 2-7).

Bar thicknesses for Channel belt 1 were acquired from 2 channel bar deposits with a roll-over top, which is indicative of non-eroded channel bar deposits (Chamberlin and Hajek, 2015). The bar thickness were acquired from story 4 of channel belt 1 using the same method shown in Figure 2-8. The uncompacted thicknesses of these bars are $2.2 \mathrm{~m}$ and $4.4 \mathrm{~m}$. The bankfull paleochannel depths estimated from cross-set thicknesses using the SVR model was determined from measurements of 32 cross-set thicknesses. Depth estimates range from 6.1 - $13.9 \mathrm{~m}$ (Table 2-2).

Depths could not be estimated from measured bar thicknesses for Channel belt 2 because of the compound nature of bars, erosional truncation and partial preservation of the bar deposits. However, these partial bars can constrain minimum paleochannel to $>0.83-2.2 \mathrm{~m}$. The bankfull paleochannel depth estimated from the mean of 45 cross-set thicknesses ranges from $3.4-5.6 \mathrm{~m}$.

Depths could not be determined from bar thickness for Channel belt 3 because of the lack of macroform scale sand bodies, which are used to interpret fluvial channel bars. Twenty-eight cross-set thicknesses were used to calculate the mean cross-set thicknesses used for SVR dune height prediction and paleochannel depth estimation. This yielded a depth estimate of $2.8-4.7 \mathrm{~m}$.

Depth was estimated from bars with roll-over tops, which indicate they are fully preserved fluvial channel bar deposits (Figure 2-8) (Chamberlin and Hajek, 2015). Bar thicknesses, which were measured from 2 bars in story 1 are $4.6 \mathrm{~m}$ and $5.5 \mathrm{~m}$, and 1 bar in story 2 of Channel belt 4 is $3.3 \mathrm{~m}$. The bankfull paleochannel depth estimated from 37 cross-set thickness measurements from Channel belt 4 ranges from $3.6-9.6 \mathrm{~m}$. The similarity in SVR predicted and bar thickness predicted bankfull paleochannel depths from story 1 and 2 of Channel belt 4 indicates that Paleochannel depths predicted using SVR is accurate (Table 2-1 and Table 2-2). 


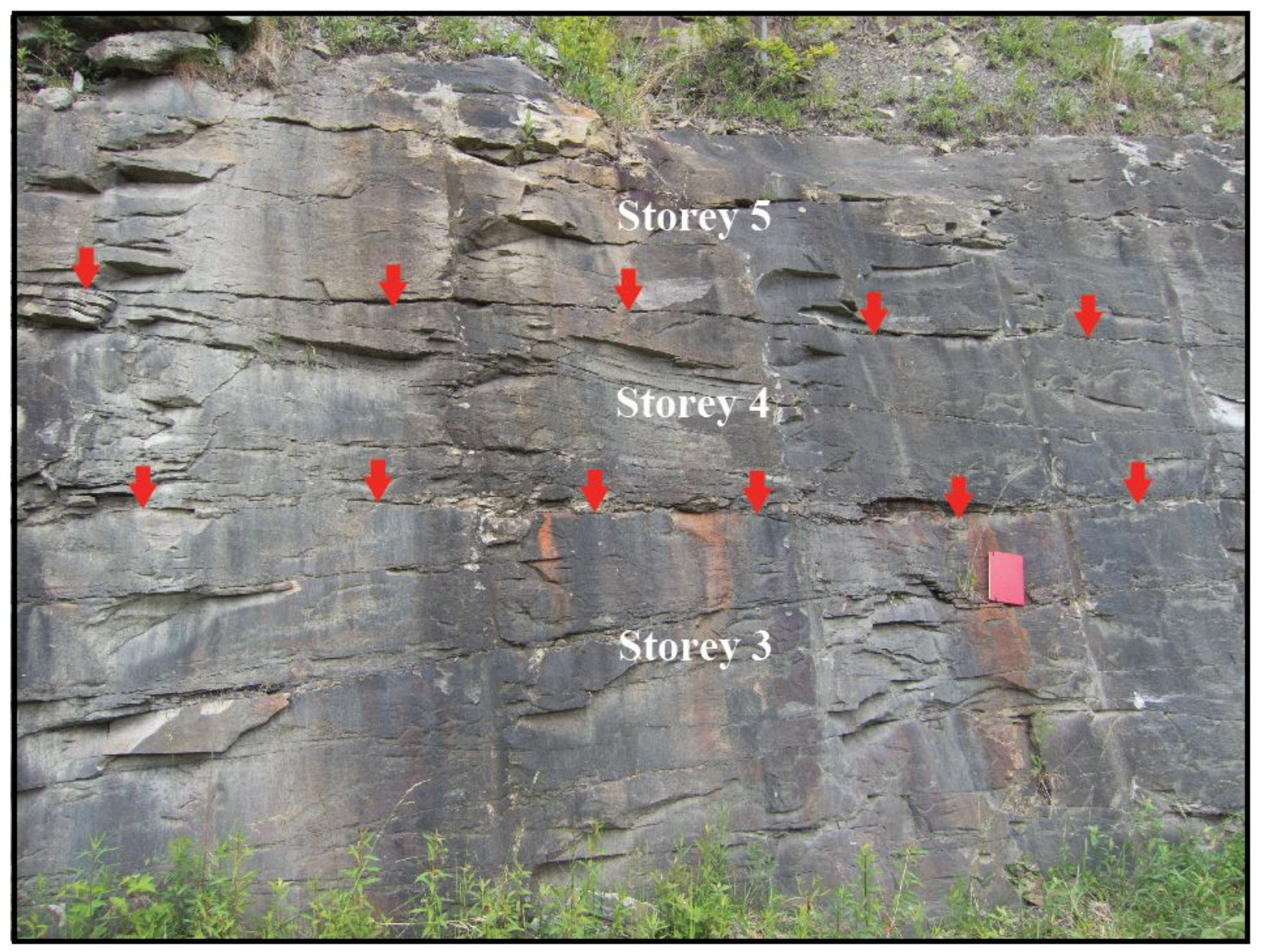

Figure 2-7: Channel belt 1 outcrop. Arrows highlighting truncation of channel bar deposits in Channel belt 1 . Notebook is $25 \mathrm{~cm}$ long. 
Table 2-1: Results of Estimated Paleochannel Geometry

\begin{tabular}{|c|c|c|c|c|c|c|}
\hline $\begin{array}{l}\text { MPAF } \\
\text { Channels }\end{array}$ & $\begin{array}{l}\text { Range of Bar } \\
\text { Thickness } \\
\quad(\mathrm{m}) \\
\begin{array}{c}n=\text { number } \\
\text { of bars }\end{array}\end{array}$ & $\begin{array}{c}\text { Mean Cross- } \\
\text { set Thickness } \\
\quad(\mathrm{m}) \\
\begin{array}{c}n=\text { number of } \\
\text { cross-sets }\end{array}\end{array}$ & $\begin{array}{c}\text { Depth Range } \\
\text { from Pre- } \\
\text { compaction Bar } \\
\text { Thickness (m) }\end{array}$ & $\begin{array}{c}\text { Depth Range } \\
\text { from SVR } \\
\text { Estimate of Dune } \\
\text { Height for } \\
\text { channel depth of } 6 \\
\text { - } 10 \text { times dune } \\
\text { height }(\mathrm{m})\end{array}$ & $\begin{array}{c}\text { Width (W) } \\
\text { from sand- } \\
\text { body (m) } \\
\begin{array}{c}n=\text { number } \\
\text { of channel } \\
\text { widths }\end{array}\end{array}$ & $\begin{array}{c}\text { w/dm from scaling } \\
\text { relationships } \\
\text { (Gibling } 2006 \\
\text { channel } \\
\text { classification) }\end{array}$ \\
\hline $\begin{array}{l}\text { Channel belt } 1 \\
\text { (Multistorey) }\end{array}$ & $\begin{array}{l}>2-4 \\
n=6\end{array}$ & $\begin{array}{c}0.33 \\
n=23\end{array}$ & $>2.2-4.4$ & $6.1-13.9$ & $\begin{array}{c}13.4-40.3 \\
n=5\end{array}$ & $\begin{array}{l}5-50 \\
\text { (fixed Rivers) }\end{array}$ \\
\hline $\begin{array}{l}\text { Channel belt } 2 \\
\text { (Multistorey) }\end{array}$ & $\begin{array}{c}>0.75-2 \\
n=3\end{array}$ & $\begin{array}{c}0.21 \\
n=45\end{array}$ & $>0.83-2.2$ & $3.4-5.6$ & $\begin{array}{c}>15.2-28.8 \\
n=2\end{array}$ & $\begin{array}{l}50-1000 \text { (Braided } \\
\text { and low sinuosity) }\end{array}$ \\
\hline $\begin{array}{l}\text { Channel belt } 3 \\
\text { (Single storey) }\end{array}$ & NA & $\begin{array}{c}0.17 \\
n=28\end{array}$ & NA & $2.8-4.7$ & NA & $\begin{array}{l}50-1000 \text { (Braided } \\
\text { and low sinuosity) }\end{array}$ \\
\hline $\begin{array}{l}\text { Channel belt } 4 \\
\text { (Multistorey) }\end{array}$ & $\begin{array}{l}3-5 \\
n=3\end{array}$ & $\begin{array}{l}0.25 \\
n=37\end{array}$ & $3.3-5.5$ & $3.6-9.6$ & $\begin{array}{c}>17-27.6 \\
n=3\end{array}$ & $\begin{array}{c}30-250 \\
\text { (Meandering) }\end{array}$ \\
\hline
\end{tabular}

$\mathrm{NA}=$ Insufficient data from field 
Table 2-2: Results of Estimated Paleogeometry (Channel depth and width), Paleoslope and Paleodischarge

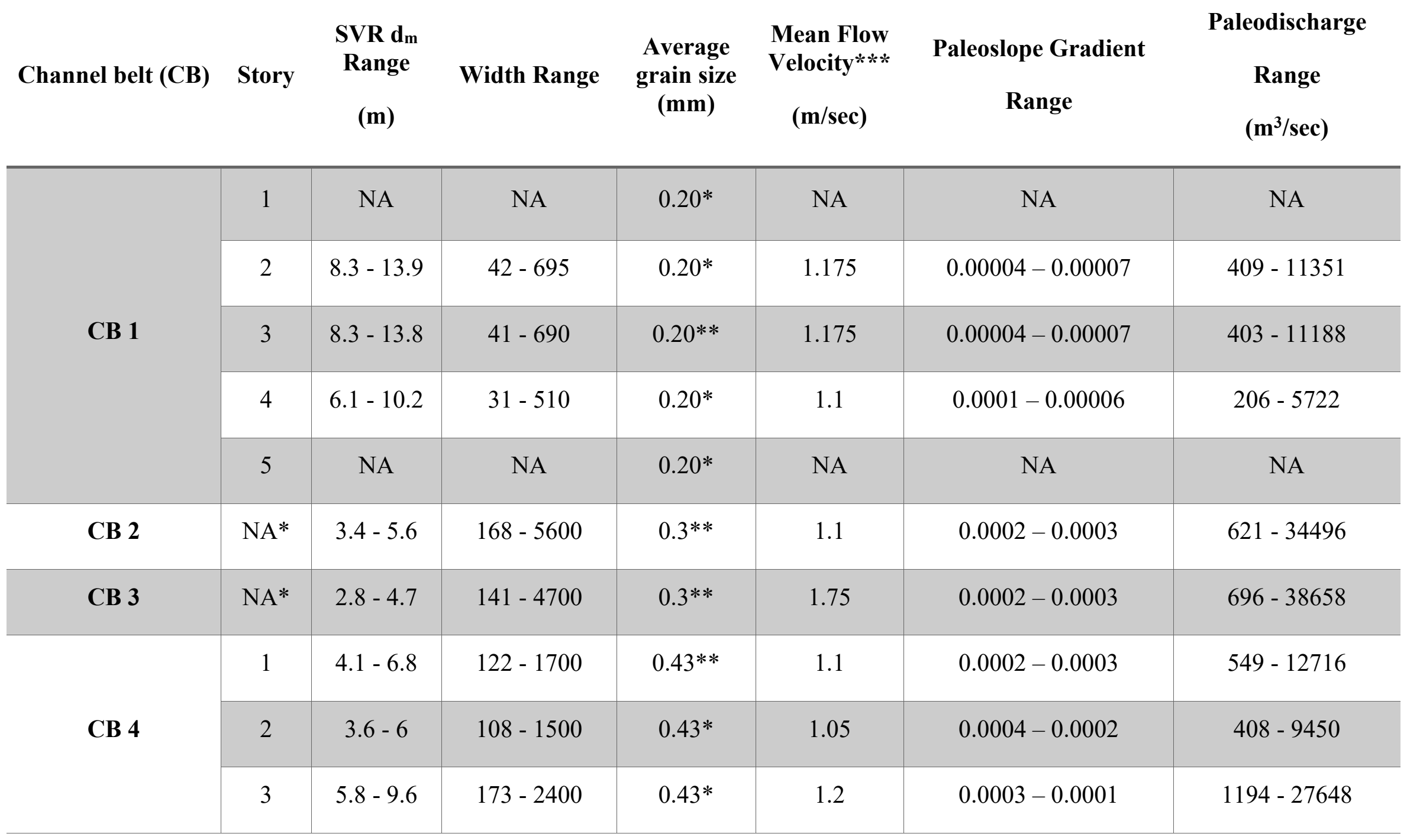

$\mathrm{NA}=$ Not Applicable due to Insufficient data from outcrop, $\mathrm{d}_{\mathrm{m}}=$ mean bankfull depth, $* * *=$ estimated using bed form diagram, $* *=$ calculated using data from thin section and grainsize card, $*=$ Data from grain size card 


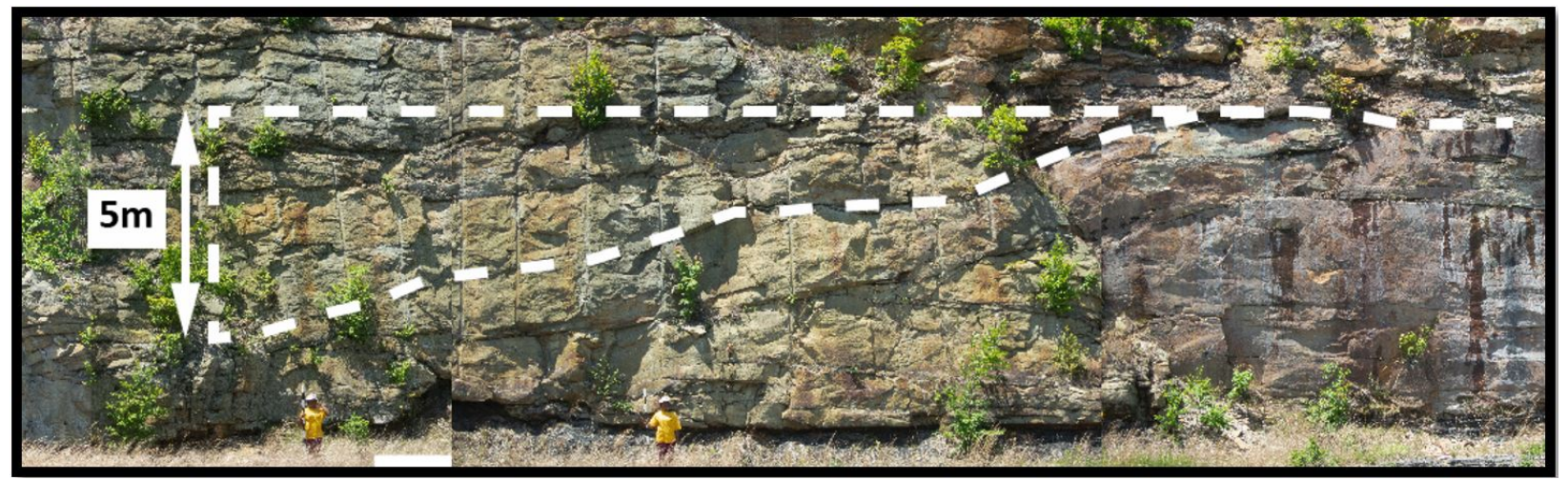

Figure 2-8: Example of how direct measurement of preserved bar is measured from outcrop data in Channel belt 4 .

\subsection{Paleochannel Width Estimates}

The apparent width of the channel boundaries were measured the boundaries of incised channel deposits. The incised paleochannel widths represent minimum channel widths as the upper channel margins were commonly truncated. Channel widths were determined from nine sand bodies in the channel belts (Table 2-1). Apparent channel width was corrected for true width using paleocurrent direction. Paleocurrent direction was determined by 116 measurements of the orientation and dip of trough cross-beds. Measured channel width estimates range from values greater than the $13.4 \mathrm{~m}$ to $40.3 \mathrm{~m}$ measured widths from the outcrop.

Channel widths were also estimated from the scaling relationships of channel width (w) to depth $\left(\mathrm{d}_{\mathrm{m}}\right)$ ratio defined using modern systems by Gibling (2006). Estimated SVR channel depths were used to determine channel width. Channel width was estimated for individual stories in Channel belts 1 and 4 based on their interpreted channel styles. The paleochannel widths acquired from Channel belt 1 outcrop were from preserved channel boundaries, so the width was recorded as actual width. The paleochannel widths, which were determined from the measurement of 5 channel boundaries from channel belt 1 deposits are up to $40.3 \mathrm{~m}$ (Table 2-1). The measured paleochannel widths determined from the deposits of Channel belt 1 falls within the channel width ranges determined from the scaling relationship. The width range determined from the scaling relationship is $31-695 \mathrm{~m}$ (Table 2-2). The width was determined by using the minimum and maximum w/d of 5 and 50, and SVR bankfull flow depth estimates of $6.1-13.9$ $\mathrm{m}$ (Table 2-1 and Table 2-2). The common w/d ratios for fixed channels in distal humid environments (Gibling, 2006) were used for widths analysis in Channel belt 1.

The measured paleochannel widths of the fluvial channel incision from Channel belt 2 are $15.2 \mathrm{~m}$ and $28.28 \mathrm{~m}$ (Table 2-1). Two instances of channel incision were observed in Channel belt 2 . The deposits of the incised channel were eroded therefore the upper boundaries of the paleochannels could not be determined. The w/d scaling relationship of $50-1000$ for braided fluvial channels (Gibling, 2006) and mean flow depths estimated from the SVR were 
used for estimating widths for Channel belt 2 . The paleochannel width range derived from w/d scaling relationship is $168-5600 \mathrm{~m}$ (Table 2-2).

Channel belt 3 does not have enough sedimentary features to determine channel width. It was difficult to measure any form of channel boundaries because deposits of Channel belt 3 did not have macroforms such as channel bars that could be used in identifying channel boundaries. The w/d scaling relationship of $50-1000$, for braided and low sinuosity fluvial channels (Gibling, 2006) and mean flow depths estimated from the SVR were used for width estimate in channel belt 3 . The paleochannel width range derived from $\mathrm{w} / \mathrm{d}$ scaling relationship is $141-$ $4700 \mathrm{~m}$ (Table 2-2).

The paleochannel incision widths measured from channel belt 4 are up to $27.6 \mathrm{~m}$ (Table 2-1). There were 3 instances of channel incision in Channel belt 4 . The deposits in the channel incision were also eroded at the upper section, which made it impossible to estimate the true channel widths. The w/d scaling relationship of $30-250$, for meandering fluvial channels (Gibling, 2006) was used for estimating widths in Channel belt 4. The paleochannel width range derived from $\mathrm{w} / \mathrm{d}$ scaling relationship is $108-2400 \mathrm{~m}$ (Table 2-2).

\subsection{Paleoslope Estimation}

The paleoslope was estimated using grain size determined from thin-section petrography and a grain size card with a graphical representation of Wentworth grain size classes (Grain size Table in Channel Paleohydrology supplementary data). The overall grain sizes of the MPAF channels deposits range from pebble to clay sizes, which is common in fluvial channel deposits (Table 2-2). The clastic sediment of the MPAF fluvial channels are moderately sorted. The sediment grain sizes of Channel belt 1 ranges from coarse to fine-grained sand $(0.5-0.17 \mathrm{~mm})$ with the fine to medium-grained sand $(\sim 0.25 \mathrm{~mm})$ being the most dominant mode. The grain sizes of Channel belt 1 from thin section analysis yielded a $D_{50}$ grain size value of $0.23 \mathrm{~mm}$, categorized as fine-grained sandstone. The sediment grain sizes of Channel belt 2 varies from coarse to fine-grained sand $(0.1-1.05 \mathrm{~mm})$. Thin section analysis of Channel belt 2 resulted in a $\mathrm{D}_{50}$ grain size value of $0.33 \mathrm{~mm}$, categorized as medium-grained sandstone. Channel belt 3 has sediment that varies from pebble to medium-grained sand $(>2 \mathrm{~mm}-0.25 \mathrm{~mm})$. The $\mathrm{D}_{50}$ value of Channel belt 3 is $0.3 \mathrm{~mm}$, categorized as medium-grained sandstone. Channel belt 4 sediment clast size varies from pebble to mud $(>2 \mathrm{~mm}-<0.088 \mathrm{~mm})$. Channel belt 4 grains have a $\mathrm{D}_{50}$ value of $0.4 \mathrm{~mm}$, categorized as medium-grained sandstone.

Paleoslope of the MPAF channels estimated using Equation 8 ranges from 0.00007 to 0.0004 (Table 2-2), which suggests a low paleoslope comparable to slope ranges for the Amazon, Mississippi and Niger Rivers, (Slope range $0.00002-0.0005$; Blum et al., 2013). The estimated paleoslope for Channel belt 10.00007 to 0.0001 . The estimated paleoslope for the other channels are: Channel belt 2 are $0.0002-0.0003$, Channel belt 3 are $0.0002-0.0003$, and Channel belt 4 are $0.0001-0.0004$, which are an order of magnitude steeper than the estimated slope of the low sinuosity channel. The estimated lowest slope for Channel belt 1 agrees with the dominant fine grain size observed in the sand body.

\subsection{Paleohydrology}


The MPAF channel belt flow velocities, which were estimated using the bedform phase diagram, ranges from $0.6-2 \mathrm{~m} / \mathrm{s}$ (Figure 2-9 and Table 2-2). The flow velocity of Channel belt 1 is in the range of $0.85-1.5 \mathrm{~m} / \mathrm{s}$. The estimated flow velocity of Channel belt 1 was determined by using the bankfull depth range of $6.1-13.9 \mathrm{~m}$, the dominant sedimentary structure, which is trough cross-stratification produced by dune bedforms, and the fine-grained sand bed form diagram. The estimated flow velocity of Channel belt 2 ranges from $0.6-1.6 \mathrm{~m} / \mathrm{s}$. The flow velocity of Channel belt 2 was determined using the bankfull depth range of $3.4-5.6 \mathrm{~m}$, and plotting the chart area for the dominant sedimentary structure, which is dune scale cross-sets, on the medium-grained sand bedform phase diagram. Channel belt 3 deposits are dominated by lamination produced from low-amplitude, upper flow regime bedform; therefore, the bankfull depth range of $2.8-4.7 \mathrm{~m}$ was used to estimate a velocity range of $1.5-2 \mathrm{~m} / \mathrm{s}$. The velocity of Channel belt 4 was determined using the dominant sedimentary structure, which is the dunescale cross-sets and the estimated channel depth range of 3.6-9.6 $\mathrm{m}$ to estimate the velocity, which ranges from $0.6000-1.7 \mathrm{~m} / \mathrm{s}$. Paleodischarge for the channel belts range from $206-$ $38658 \mathrm{~m}^{3} / \mathrm{sec}$. Channel belts 2 and 3 with paleodischarge values of $621-34496 \mathrm{~m}^{3} / \mathrm{sec}$ and 695 $-38658 \mathrm{~m}^{3} / \mathrm{sec}$ are the highest paleodischarge. The other paleodischarge ranges are $206-11351$ $\mathrm{m}^{3} / \mathrm{sec}$ for Channel belt 1 and 408 to $27648 \mathrm{~m}^{3} / \mathrm{sec}$ for Channel belt 4 (Table 2-2). 


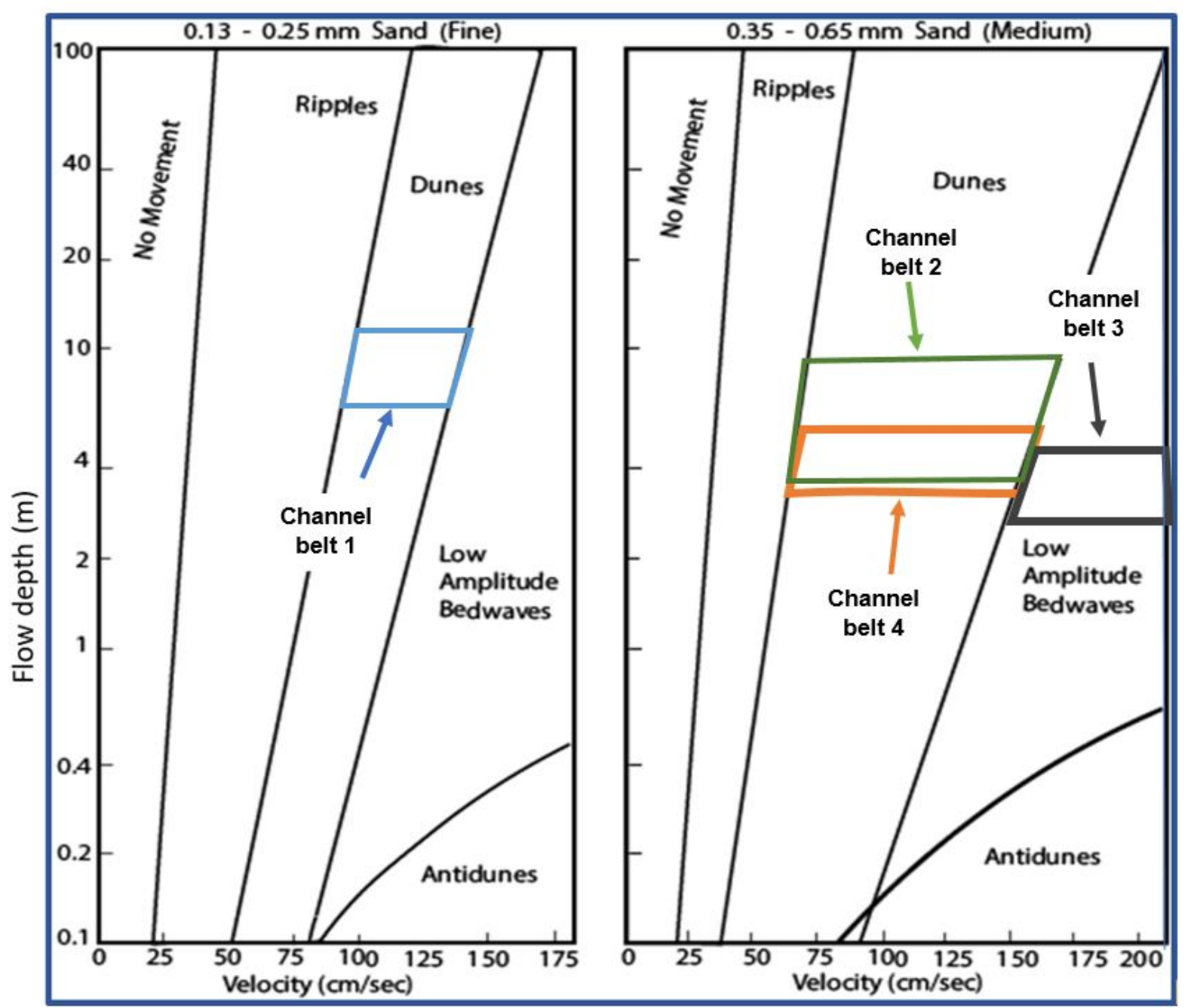

Figure 2-9: Fine and medium-grained bedform phase diagrams of Rubin and McCulloch, 1980. Estimated range of velocity for channel belt 1 is $85-145 \mathrm{~cm} / \mathrm{sec}$, channel belt 2 is $60-160$ $\mathrm{cm} / \mathrm{sec}$, channel belt 3 is $150-200 \mathrm{~cm} / \mathrm{sec}$ and channel belt 4 is $60-170 \mathrm{~cm} / \mathrm{sec}$.

\subsection{Errors and Uncertainties Associated with Numerical Analysis}

Measurement of channel fill structures in the outcrop is subject to bias in interpretation sedimentary features from outcrop data, which represents an initial source of error. Detailed architectural analysis of outcrop aided the identification of channel bar (Bridge, 2009; Holbrook and Wanas, 2014). Other problems associated with measuring thickness data from channel bar include compaction and erosion. The degree of compaction is dependent on several factors such as original packing, original void ratio, shape of grains, degree of roundness of grains sand composition and size grading (Ethridge and Schumm, 1977). Equation 1, which considers factors that affect the degree of compaction, was used to compensate for the $10 \%$ error due in measured bar thickness to compaction. It is impossible to estimate channel depth from an eroded bar, hence data from eroded bar were recorded to give a minimum estimate of channel bar thickness. Errors associated with identifying and measuring channel bars can be up to 60\% (Holbrook and Wanas, 
2014). Errors identifying channel bar thickness using story thicknesses can be up to $25 \%$ (Holbrook and Wanas, 2014). Mean channel depth estimated from cross-set thickness is subject to the bias of preferential preservation of dunes during waning flow, which may not be representative of actual bankfull flow. This results in the estimation of mean dune heights that are not representative of actual flow conditions, which causes errors in the depth estimates. Mean channel depth estimated from dune height and cross-set thickness by using Equation 5 have errors up to $25 \%$ if the depth range is averaged (Holbrook and Wanas, 2014). The accuracy of dune heights estimated using SVR is $84 \%$. The score was calculated using the coefficient of $\mathrm{R}^{2}$. Errors associated with estimating channel depth with Equation 5 will also be encountered (Pedregosa et al., 2011). Measurement of channel width is also subject to the bias of interpretation, which may lead to errors in data acquired. Accuracy of channel width measurement is dependent on the identification of channel banks, which proved to be extremely difficult in the study outcrop. Channel width estimated form scaling factors have error ranges by a factor of \pm 4 (Blum et al., 2013). Channel dept and width estimated from the rock record are representative of extreme events, which may have resulted in extreme geomorphology and discharge than is normal to the depositional system (Gibling, 2006). Error associated with slope estimates is the assumption that bed shear stress required to move the sediment load is constant across the channel. The bankfull shield number used as a constant is for slope estimation varies by \pm 2 (Holbrook and Wanas, 2014). The grain size used for estimating slope is an average value and was measured with a Wentworth grain size calibrated card, which has errors of $\sim 1 / 2$ phi (Lin and Bhattacharya, 2017). The errors associated with paleodischarge estimates are up to an order of magnitude (Holbrook and Wanas, 2014; Lin and Bhattacharya, 2017). The instantaneous paleodischarge estimates are not representative of the annual or seasonal discharge in the paleochannel. The instantaneous discharge equation is a function of velocity of bankfull floodwaters, cross-sectional area of a channel, assuming the sediment supply is constant. The assumption of constant sediment supply adds more errors to the paleodischarge estimates as sediment type and sediment load varies. Another error associated with the paleodischarge estimate is based on the assumption that the cross-sectional area of a channel is the same, which is not so (Holbrook and Wanas, 2014). The cross-sectional area was also calculated using depth and width estimates, which means the errors from those numerical estimates are reflected in paleodischarge estimates. Additionally, the estimates from the instantaneous discharge have errors because the cross-sectional area for the paleochannels is estimated from mostly eroded channel deposits, which may not be representative of the actual sediment load.

Uncertainties for the estimated channel depth, channel width, slope, flow velocity and paleodischarge (Table 2-3) were determined using the uncertainty equation (Analytical Methods Committee, 1995). The result showed that there are large uncertainties associated with the depth, width, slope, flow velocity and discharge estimates because of the wide range of values being estimated which reflects the dynamic nature of fluvial processes and the resulting planform.

Table 2-3: Uncertainties for Estimated Fluvial Channel Depth, Slope, Width, Flow Velocity and $\underline{\text { Discharge }}$ 


\begin{tabular}{|c|c|c|c|c|c|c|}
\hline $\begin{array}{l}\text { Channel } \\
\text { Belts } \\
\text { (CB) }\end{array}$ & Story & $\begin{array}{l}\text { SVR dm } \\
\text { uncertainty }\end{array}$ & $\begin{array}{l}\text { Slope Uncertainty } \\
\text { (Min-Max Range) }\end{array}$ & $\begin{array}{c}\text { Width } \\
\text { Uncertainty (Min- } \\
\text { Max Range) }\end{array}$ & $\begin{array}{l}\text { Flow Vel. } \\
\text { Uncertainty (Min- } \\
\text { Max Range) }\end{array}$ & $\begin{array}{c}\text { Discharge } \\
\text { Uncertainty (Min- } \\
\text { Max Range) }\end{array}$ \\
\hline \multirow[t]{5}{*}{ CB 1} & 1 & NA & NA & NA & NA & NA \\
\hline & 2 & \pm 2.78 & \pm 0.000015 & \pm 326.65 & \pm 0.275 & \pm 5471.2 \\
\hline & 3 & \pm 2.76 & \pm 0.000015 & \pm 324.3 & \pm 0.275 & \pm 5392.8 \\
\hline & 4 & \pm 2.04 & \pm 0.000020 & \pm 239.7 & \pm 0.25 & \pm 2758.1 \\
\hline & 5 & NA & NA & NA & NA & NA \\
\hline CB 2 & NA* & \pm 1.12 & \pm 0.000055 & \pm 2716 & \pm 0.5 & \pm 16937.5 \\
\hline CB 3 & $N A^{*}$ & \pm 0.94 & \pm 0.000065 & \pm 2279.5 & \pm 0.25 & \pm 18980.8 \\
\hline \multirow[t]{3}{*}{ CB 4} & 1 & \pm 1.36 & \pm 0.000065 & \pm 788.8 & \pm 0.45 & \pm 6083.3 \\
\hline & 2 & \pm 1.2 & \pm 0.000073 & \pm 696 & \pm 0.45 & \pm 4520.9 \\
\hline & 3 & \pm 1.92 & \pm 0.000046 & \pm 1113.6 & \pm 0.5 & \pm 13226.8 \\
\hline
\end{tabular}

\section{Discussion}

\subsection{Machine-assisted Paleohydrological Analysis}

The machine-assisted SVR analysis increased the accuracy of dune height prediction from cross-set thickness resulting in a higher accuracy of estimated channel depth. The results of the SVR analysis were compared to the widely used polynomial regression model developed by Leclair and Bridge (2001) using mean square error and overall predictions showed comparable and in most cases better performance. The result from mean square error analysis showed that the SVR model had a root mean square error (RMSE) of $9 \mathrm{~mm}$ while the polynomial model had an RMSE of $16.8 \mathrm{~mm}$.

\subsubsection{Advantages of SVR over Polynomial Regression}

The SVR model considers outlier data when estimating dune cross-strata thickness. Furthermore, SVR analysis is done in a higher dimension so it allows for a comparison of additional variables that may improve prediction. For example, cross-set length may be added to the SVR model to improve the accuracy of predicted dune height. In geology, all data are important because they reflect the variability of the conditions during bed formation. The model of Leclair and Bridge (2001) was based on the data along the best line of fit. The predictions of the SVR model is non-linear due to the use of the Gaussian kernel. i.e. the model uses normal distribution to predict the zone of best fit. The result of utilizing outlier data and the Gaussian kernel is a more accurate prediction as evident by the RMSE of SVR compared to the previous model. 
Paleodischarge vs Paleoslope

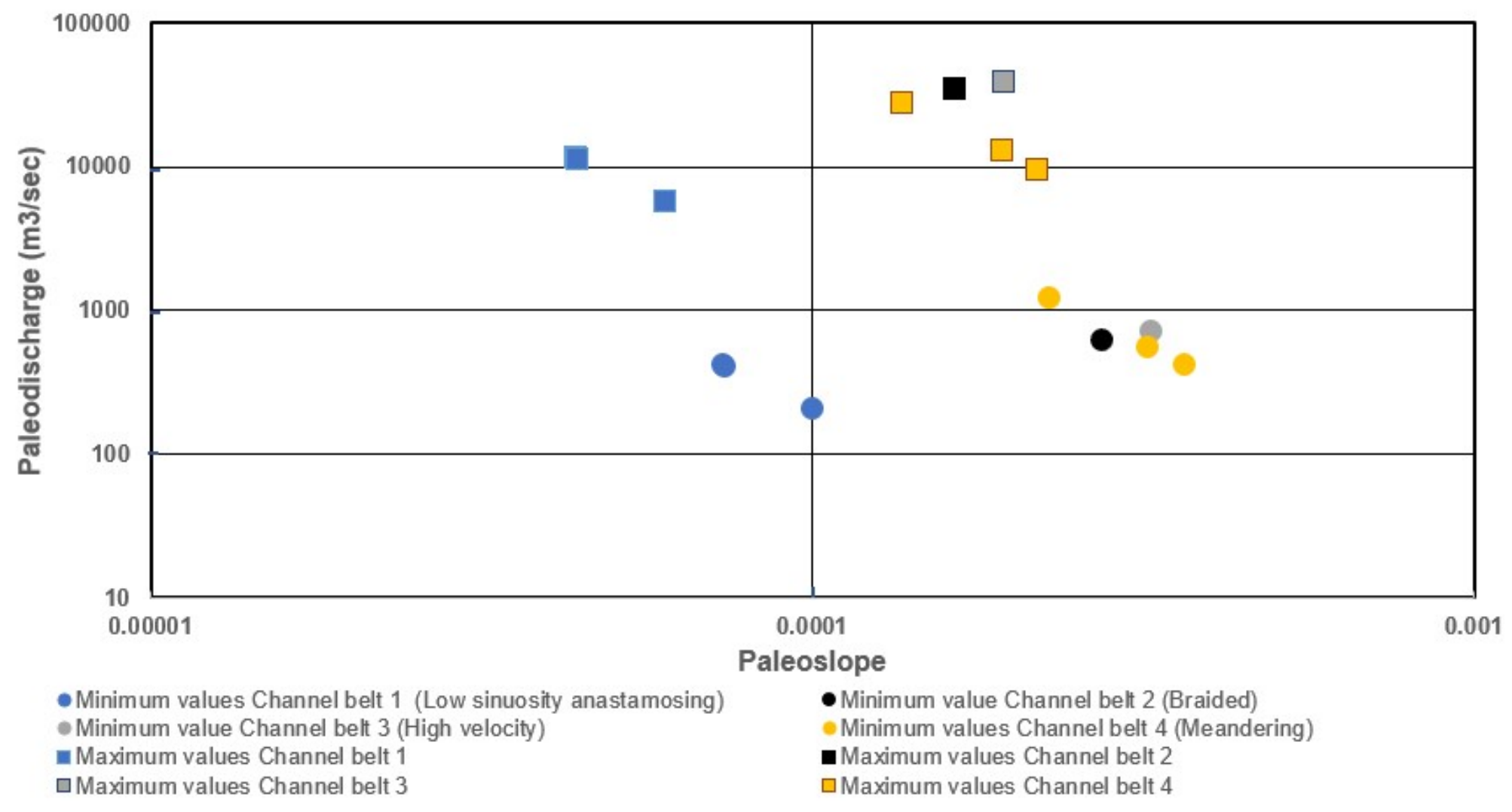

Figure 2-10: Plot of paleodischarge versus paleoslope of MPAF channels at Birch River, WV. $\mathrm{CB}=$ Channel belt. 


\subsection{Channel Belt Evolution}

Facies architecture, channel dimensions, paleoslope and paleodischarge of the MPAF channel belts reveal an evolution of fluvial channel form in response to changing paleohydrological conditions. Of note, the channel depth shows variability among MPAF channels: $6.1-13.9 \mathrm{~m}$ for channel belt 1, 3.4 - 5.6 $\mathrm{m}$ for Channel belt 2, 2.8 - 4.7 $\mathrm{m}$ for Channel belt 3, and 3.6-9.6 $\mathrm{m}$ for Channel belt 4 . Channel width estimated from scaling relationships showed that the low sinuosity channels had a lower range of width, while the braided channels had the largest width range. The independently estimated paleoslope and paleodischarge, which were compared amongst the MPAF channel belts (Table 2-2), showed that all the channel belts at the study location had a low slope $(0.00007-0.0004)$ and variable paleodischarge (Figure 2-10). The estimated paleoslope of the lower MPAF channel belts are similar to slope ranges for the Amazon, Mississippi and Niger Rivers, (Slope range 0.00002 - 0.0005; Blum et al., 2013). This indicates that the paleoslope estimates obtained for the MPAF fluvial systems are consistent with physiographic models that suggest MPAF were deposited in low- gradient environments caused by unloading type relaxation of the foreland basin (Cecil, 1990; Cecil et al., 2003; Greb et al., 2008). Given the relatively low paleoslope estimated for all MPAF channel belt, the formation of upper plane beds and low amplitude bedforms from high-velocity flow are considered to reflect flooding events caused by intense precipitation (Kosanke and Cecil, 1996; Miall, 1996, 2014; Cecil and Dulong, 2003; Cecil et al., 2003).

Results indicate Channel belt 1 deposits formed from a low gradient, fine-grained, lowsinuosity channel form in an anastomosing fluvial system. Channel belt 1 has the thickest channel depth $(6.1-13.9 \mathrm{~m})$, which results in a relatively low w/d. This low w/d combined with the grain size, slope and an abundance of coal intraclast and large plant fragments may reflect channel confinement due to bank stabilization by vegetation. The abundance of coal intraclasts and large plant fragments suggest abundant vegetation, which flourished in the humid climate, surrounded areas in the low sinuosity fluvial system (Cecil, 1990, 2003; Allen et al., 2014). The estimated range for the paleoslope of the low-sinuosity channel of 0.00007 to 0.0001 , is an order of magnitude lower than other MPAF channels in the study area. The low slope and high amount of fine-grained deposits may have contributed to Chanel belt 1 having the relatively highest channel depth and a low w/d (Gibling, 2006). The estimated paleodischarge for Channel belt 1 is $206-11351 \mathrm{~m}^{3} / \mathrm{sec}$. This range of paleodischarge rate is the lowest of all the MPAF channel belts in the study area and is consistent with the abundance of fine-grained sediments deposited (Figure 2-10, Miall, 1996, 2014; Catuneanu, 2006).

Channel belt 2 directly overlies Channel belt 1 (Figure 2-2 and Figure 2-3) and contains features that indicate deposition by a braided fluvial system in a humid climate, with low channel confinement, low paleoslope, and high paleodischarge. Channel belt 2 deposits are characterized by an abundance of trough cross-stratified, medium-grained sand, with a paleochannel depth range of $3.4-5.6 \mathrm{~m}$. The abundance of trough cross-stratification suggests that the channel system was dominated by 3D dunes. The low paleochannel depth, higher slope values $(0.0002-$ $0.0003)$ and higher paleodischarge $\left(621-34496 \mathrm{~m}^{3} / \mathrm{sec}\right)$ compared to other MPAF channel belts (Figure 2-10), suggest that the braided channel style of Channel belt 2 is due to mainly to an increased slope gradient. Channel belt 2 is interbedded with some plant trunk and coal clast, 
which suggests an abundance of vegetative material in the fluvial system; this suggests that the area was vegetated, but this vegetation wasn't sufficient for bank stabilization.

Overlying the No. 5 block coal bed (Figure 2-2 and Figure 2-3), Channel belt 3 sandstones were deposited by a low gradient, high-velocity fluvial system in a seasonal semi-arid climate. Channel belt 3 is characterized by an abundance of medium-grained, low amplitude bedforms and a relatively high width to depth ratio. The abundance of low amplitude bedforms in Channel belt 3 was attributed to high-velocity flooding event(s), which is supported by high paleodischarge values $\left(695-38658 \mathrm{~m}^{3} / \mathrm{sec}\right)$ compared to other MPAF channel belts. Channel belt 3 exhibits the shallowest paleochannel depths estimates compared to the other MPAF channels. This combined with the low paleoslope for channel belt $3(0.0002-0.0003)$ suggests that high-velocity flow resulted from a control other than paleoslope (Cecil, 2003; Cecil and Dulong, 2003; Plink-Björklund, 2015). The Burdekin River is an analog system developed in a seasonally wet-dry climate that experiences high velocity flows due to monsoonal precipitation events during wet seasons (Fielding and Alexander, 1996). The Burdekin River, just like CB 3, is dominated by upper plane beds and dunes, which represent fluctuating periods of extreme and moderate flow events.

Channel belt 4 directly overlies Channel belt 3 and contains features that indicate deposition by a low-gradient sinuous fluvial system. The high-velocity channel (Channel belt 3 ) is overlain by Storey 1 of the sinuous channel (Channel belt 4). Story 1 is characterized by coarse to medium-grained, inclined sandstone beds with a channel depth range of $4.1-6.8 \mathrm{~m}$ (Table 22). The occurrence of convoluted beds and root stumps in the Storey 1 of the may have been due to changes water levels of the fluvial system brought about by seasonality in rainfall due to increasing aridity (Cecil, 2003; Cecil and Dulong, 2003; Fielding et al., 2009; Allen et al., 2014; Plink-Björklund, 2015). Overlying Storey 1 is the Lower Kittanning coal bed, which is overlain by Storeys 2 and 3. Stories 2 and 3 are characterized by coarse to medium-grained, inclined sandstone beds with a channel depth range of $3.6-9.6 \mathrm{~m}$ (Table 2-2). The paleoslope (0.0001$0.0004)$ and paleodischarge $\left(408-27648 \mathrm{~m}^{3} / \mathrm{sec}\right)$ values of channel belt 4 indicate an order of magnitude increase in the maximum paleodischarge rate despite the low channel gradient.

The effect of paleochannel geometry, paleoslope, and paleohydrology on the fluvial channel architecture and depositional style of the MPAF varies. The geometry of the MPAF channel varies in the study area. The channel width and depth, which has been used to compare fluvial channels of arid to humid differing climatic regimes (Fielding et al., 2009; Allen et al., 2014), was used to compare the MPAF channels. The depth ranges for the MPAF channels showed variability among MPAF channel belts: $6.1-13.9 \mathrm{~m}$ for channel belt 1, 3.4 - 5.6 $\mathrm{m}$ for Channel belt 2, 2.8 - 4.7 $\mathrm{m}$ for Channel belt 3, and 3.6-9.6 $\mathrm{m}$ for Channel belt 4 . The independently estimated paleoslope and paleohydrology, which were compared amongst the MPAF channel belts (Table 2-2 and Figure 2-10), showed that the variation in channel depth of all the channel belts at the study location had developed on a low slope and with variable paleodischarge (Table 2-2 and Figure 2-10). The low paleoslope observed in all MPAF channel belt also indicates that fast-flowing events that resulted in the formation of upper plane beds and low amplitude bedforms may have been due to flooding events caused by fluctuation in 
precipitation intensity (Kosanke and Cecil, 1996; Cecil, 2003; Cecil and Dulong, 2003; Miall, 2014).

\subsection{Possible Controls on Fluvial Channel Geometry and Paleohydrology}

Eustatic rise and fall of sea level may have controlled paleoslope by changing fluvial base level (Blum and Törnqvist, 2000) across the basin in which a reduction in fluvial gradient due to sea-level rise should result in a reduction of channel flow velocity, while an increase in fluvial gradient should increase channel flow velocity. Glacio-eustatic models suggest fluvial channel sandstones are mainly deposited during glaciation when base-level is low in the basin and floodplain mudrocks are deposited during interglacial periods, when the base-level is high (Falcon-Lang, 2004; Greb et al., 2008; Haq and Schutter, 2008; Falcon-Lang and DiMichele, 2010). The effects of base-level rise, and fall have a direct influence on the water levels and hence the flow depth of the fluvial channel. Sediment accommodation in a fluvial channel is limited by the water level and this is reflected in the thickness of preserved channel sand bodies of the MPAF (Shanley and McCabe, 1994; Currie, 1997; Blum and Törnqvist, 2000; Bhattacharya et al., 2016). The thicker channel depth observed in CB 1 and CB 4 may be due to eustatic base-level rise, while the lower thickness values of CB 2 and CB 4 may be due to eustatic base-level fall. However, the occurrence of water escape structures and rooting features in CB 4 sandstones suggest a variable water level in the fluvial system, which is not consistent with the eustatic base-level fluctuations. This suggests that glacio-eustasy played an important role in long term accommodation succession of the fluvial system, but other factors overprinted the glacio-eustatic control.

Tectonic controls on accommodation and physiography of the Alleghenian foreland may have affected the evolution of MPAF channel belts. Tectonic subsidence and uplift may lead to the increase or decrease of slope and hence fluvial gradient. Relaxation and uplift of a subsided Alleghenian foreland basin would have resulted in an increase of slope (Holbrook and Schumm, 1999; Holbrook et al., 2006), which we interpret to have caused an increase of the fluvial gradient and change in fluvial styles reflected in the CB 1 - 3 (Table 2-2). The effect of tectonic subsidence and uplift on the base level is similar to the eustatic effect on base level in a sedimentary basin. However, tectonic processes have third-order cycles (i.e. $>1$ my) which do not fit the higher frequency, fourth-order cycles (i.e. 0.1 - 1 my) of the MPAF channel belt (see MPAF age estimates, Figure 2-2). This implies that tectonic influence on MPAF geometry and paleohydrology has been masked by other controls. Additionally, tectonic uplifts which resulted in the formation of the Pangean Mountains may have resulted in the formation of a rain shadow zone, which led to extended periods without precipitation (Greb et al., 2008). However, the duration of tectonic processes does not match the higher frequency processes of the MPAF (DiMichele et al., 2010; Gibling et al., 2014).

Paleoclimatic control on precipitation and evapotranspiration rates and the abundance of vegetation may have influenced the geometry and hydrology of the MPAF fluvial system. An 
increase in or decrease in annual precipitation and evapotranspiration rates may have led to changes in the rate of discharge in the catchment area and fluvial system. The abundance of vegetation in different climatic conditions may also affect the geometry and hydrology of the fluvial system. The amount of vegetative cover influences the run-off in a fluvial catchment area and rooting increases the stability of channel banks (Schumm, 1968, 1981, 1988; Fielding et al., 2009). The amount of vegetative cover in the fluvial catchment area of ever-wet, humid fluvial systems have more vegetative cover and experience less erosion and water run-off compared to more arid catchment areas with less vegetative cover. Precipitation and evapotranspiration rates also vary in fluvial systems of humid and seasonally wet-dry climates (Cecil and Dulong, 2003; Cecil et al., 2004). The constant precipitation events and abundant vegetation cover in the fluvial depositional system of an ever-wet humid climate results in stable water input in the fluvial catchment area and constant paleodischarge rates in the fluvial system. Any fluctuation in the base level of the ever wet, humid fluvial system is driven by other factors such as eustasy. Also, erosion in the humid fluvial system will be limited to areas within the channel due to the stabilizing effects of abundant vegetation on the channel banks, which may lead to increased channel flow depth compared to channel width. The increased thicknesses of Channel belt 1 and Channel belt 4 deposits above the Lower Kittanning coal may be due to deposition in a humid climate characterized by constant precipitation, an abundance of vegetation and moderate paleodischarge. The sinuous channel belt (CB 4) and the low sinuosity channel belt (CB 1) have the lowest range of paleoslope and paleodischarge, except for the uniquely high paleodischarge range of the story 3 of the sinuous channel belt, which may be due to an increase in base level as a result of an increase in precipitation rates. Fluvial systems of seasonally wet-dry climates experience more evapotranspiration, which results in a reduction in water levels in the fluvial system. Precipitation events in the fluvial systems of seasonally wet-dry climates result in a sudden increase in water input to the fluvial catchment area, which results in increase paleoflow and paleodischarge (Cecil and Dulong, 2003; Fielding et al., 2009; Plink-Björklund, 2015). The relatively low thickness of the braided and high-velocity channel suggests that there was low accommodation, which may be due to the reduction of the stratigraphic base level during the periods of high evapotranspiration. The high range of paleodischarge values of the braided (CB 2) and high-velocity (CB 3) channel belts indicates a high paleoslope and fluvial gradient, which may have been due to onset of precipitation in a fluvial system previously experiencing low stratigraphic base level, which we interpret to have been caused by high evapotranspiration rates during dry season.

Paleoclimatic models developed from miospore composition of coal indicate wet-dry-wet MPAF depositional environment (Figure 2-11, Eble, 2002), which was attributed to fluctuations in paleoclimate of the Appalachian basin during the Middle Pennsylvanian (Eble, 2002; DiMichele et al., 2010; Falcon-Lang and DiMichele, 2010; Cecil, 2013). The miospore data shows lycopsid, fern, calamites and cordaites composition of MPAF coal beds at Birch River. The lycopsid indicates deposition in a wet, humid environment, while the ferns indicate deposition in a dry, arid environment. A comparison of estimated paleoslope, paleodischarge and geomorphology data with the miospore data, highlights a relationship between MPAF channel depth, paleoslope and paleodischarge, and lycopsid and fern composition. Channel paleoslope and paleodischarge range increases with increasing fern content and, while channel depth increases with increasing lycopsid content. This suggests that paleoclimate changes may have 
been controlling the MPAF channel belt geomorphology, paleoslope and paleodischarge. The miospore data shows a decrease in lycopsid and an increase in fern with time, as observed in the Little No. 5 Block coal bed, which underlies MPAF deposits of this study, to the No. 5 Block coal bed, which underlies the low sinuosity channel (Figure 2-11).

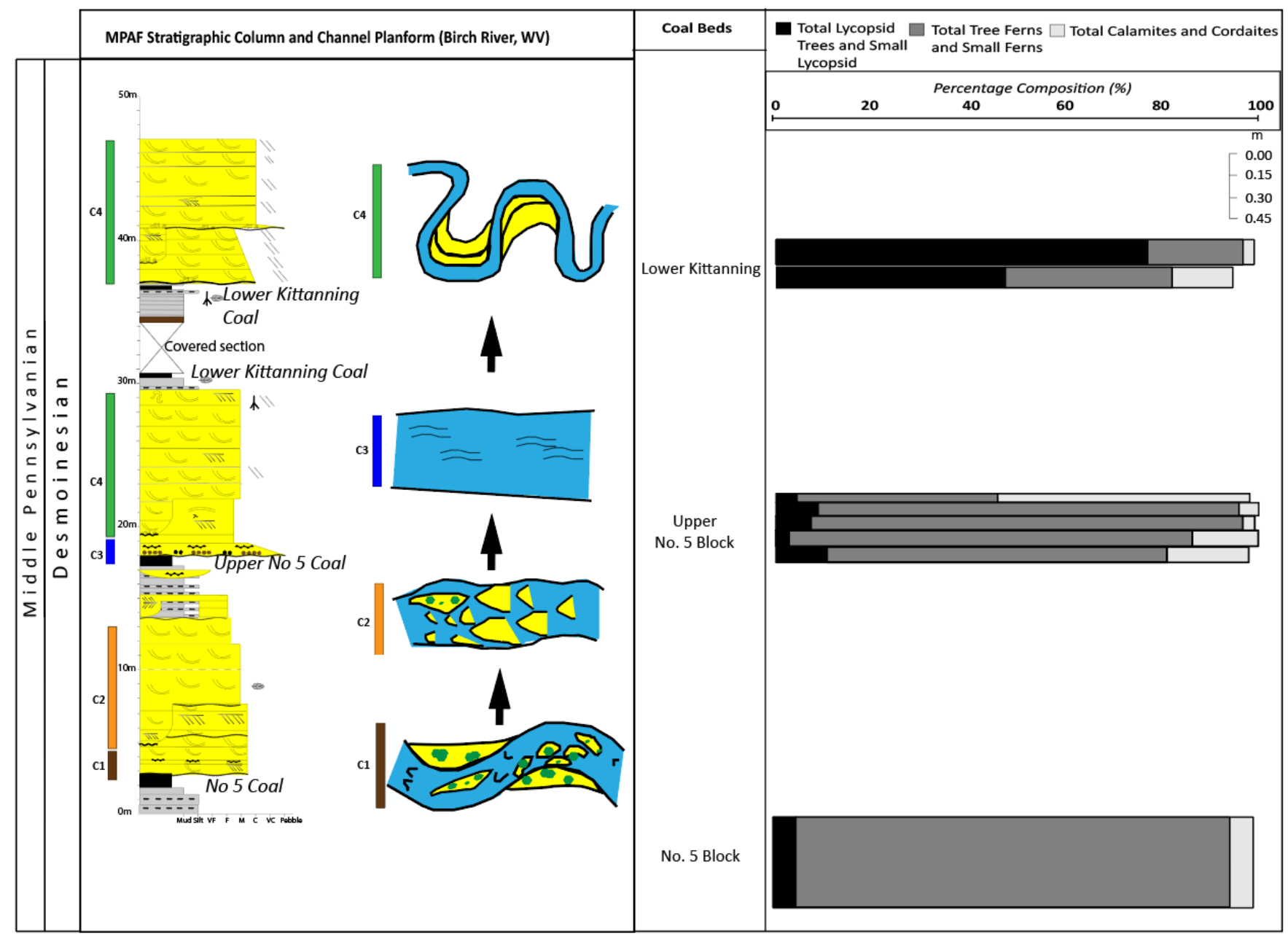

Figure 2-11: MPAF measured section and distribution of numerically significant miospore taxa, Birch River, West Virginia. Miospore data modified from Eble (2002). CB $=$ Channel Belt

Therefore, we infer that the abundance of upper plane stage beds, low amplitude bedforms in Channel belt 3 is likely due to changes in precipitation and evapotranspiration. The fluvial depositional mechanisms of the Channel belt 3, such as paleoslope and paleohydrology, that resulted in the various bedforms of the high-velocity fluvial system may have been due to the humid to semi-arid paleoclimate change during the Pennsylvanian as modeled from Pennsylvanian paleobotany and Canadian fluvial systems (Cecil, 1990; Cecil et al., 2003; Greb et al., 2008; Allen et al., 2014). A seasonal wet-dry climate, which is common in semi-arid regions, usually results in an episodic influx of large volumes of water, which may have resulted in high- 
velocity floods forming the low amplitude bedforms observed in the high-velocity channel (Fielding et al., 2009; Plink-Björklund, 2015). The increase in channel depth of the sinuous channels above the Lower Kittanning coal bed may be due to the reverse of paleoclimate to a wetter more humid climate, which is supported by the increase in lycopsid spores in the Lower Kittanning coal beds that indicate a wet environment (Kosanke and Cecil, 1996; Eble, 2002).

\section{Conclusions}

This study used numerical modeling to highlight changes in fluvial channel geomorphology and hydrology that coincides with periods of paleoclimate change during the Middle Pennsylvanian. Measured and estimated paleochannel depth and width were used to determine changes in paleoslope and paleodischarge of the MPAF channel belts. SVR machineassisted algorithm was effective in improving the accuracy of estimating dune heights and channel depth, from cross-set thickness. Paleochannel depth decreases during periods of increasing paleoclimate dryness; and then starts to increase during periods of increasing paleoclimate wetness. The decrease in paleochannel depth may be due to a reduction in stratigraphic base level caused by low annual precipitation, which is common in fluvial systems of seasonal wet-dry, semi-arid/ semi-humid climate. Paleodischarge varies across the MPAF however, MPAF zones that experienced an increase in paleodischarge coincides with periods of paleoclimate change from ever-wet humid to seasonal semi-arid climate. Paleoslope estimates indicate low gradient physiography for the MPAF depositional environment, which agrees with previous models of ancient coal forming environments in West Virginia. Further review of possible effects of eustatic, tectonic and paleoclimatic effect on the geometry and hydrology of fluvial systems indicated that paleoclimate was a dominant control on MPAF channel belt geomorphology and hydrology. By highlighting qualitative and quantitative characteristics of MPAF fluvial channels, this research shows a way of identifying the effects of paleoclimatic forcing on the hydrology and geomorphology of fluvial systems.

\section{$8 \quad$ Funding}

Field and laboratory work for this research was made possible by funds and grants from the American Association of Petroleum Geologist (AAPG) and West Virginia University. 


\section{References}

Abatan, O., Weislogel, A., and Blake Jr, B. M. (in prep). Process Based Analysis of Fluvial Stratigraphic Record: The Middle Pennsylvanian Allegheny Formation, WV. Available at: $\mathrm{PhD}$ Dissertation Chapter, West Virginia University.

Allen, J. P., Fielding, C. R., Gibling, M. R., and Rygel, M. C. (2014). Recognizing products of paleoclimate fluctuation in the fluvial stratigraphic record: An example from the Pennsylvanian to Lower Permian of Cape Breton Island, Nova Scotia. Sedimentology 61, 1332-1381.

Allen, J. R. (1982). Sedimentary structures, their character and physical basis. Elsevier Science $\&$ Technology.

Allen, J. R. L. (1970). A quantitative model of grain size and sedimentary structures in lateral deposits. Geological Journal 7, 129-146. doi:10.1002/gj.3350070108.

Analytical Methods Committee (1995). Uncertainty of measurement: implications of its use in analytical science. Analyst 120, 2303-2308.

Archer, A. W., and Greb, S. F. (1995). An Amazon-scale drainage system in the Early Pennsylvanian of central North America. The Journal of Geology, 611-627.

Arkle Jr, T., Beissel, D. R., Larese, R. E., Nuhfer, E. B., Patchen, D. G., Smosna, R. A., et al. (1979). Mississippian and Pennsylvanian (carboniferous) systems in the United States: West Virginia and Maryland. US, Geol. Surv., Prof. Pap.;(United States) 1110.

Awad, M., and Khanna, R. (2015). "Support Vector Regression," in Efficient Learning Machines: Theories, Concepts, and Applications for Engineers and System Designers, eds. M. Awad and R. Khanna (Berkeley, CA: Apress), 67-80. doi:10.1007/978-1-43025990-9 4.

Bao, Y., and Liu, Z. (2006). A Fast Grid Search Method in Support Vector Regression Forecasting Time Series. in Intelligent Data Engineering and Automated Learning IDEAL 2006 Lecture Notes in Computer Science., eds. E. Corchado, H. Yin, V. Botti, and C. Fyfe (Springer Berlin Heidelberg), 504-511. 
Bhattacharya, J. P., Copeland, P., Lawton, T. F., and Holbrook, J. (2015). Chapter 8. Estimation of source area, river paleo-discharge, paleoslope and sediment budgets of linked deeptime depositional systems and implications for hydrocarbons. Earth-Science Reviews.

Bhattacharya, J. P., Copeland, P., Lawton, T. F., and Holbrook, J. (2016). Estimation of source area, river paleo-discharge, paleoslope, and sediment budgets of linked deep-time depositional systems and implications for hydrocarbon potential. Earth-Science Reviews $153,77-110$.

Blake, B. M., Cross, A. T., Eble, C. F., Gillespie, W. H., and Pfefferkorn, H. W. (2002). Selected plant megafossils from the Carboniferous of the Appalachian Region, Eastern United States: geographic and stratigraphic distribution. Memoir-Canadian Society of Petroleum Geologists 19, 259-335.

Blum, M. D., and Törnqvist, T. E. (2000). Fluvial responses to climate and sea-level change: a review and look forward. Sedimentology 47, 2-48.

Blum, M., Martin, J., Milliken, K., and Garvin, M. (2013). Paleovalley systems: Insights from Quaternary analogs and experiments. Earth-Science Reviews 116, 128-169. doi:10.1016/j.earscirev.2012.09.003.

Bridge, J. S. (2009). Rivers and floodplains: forms, processes, and sedimentary record. John Wiley \& Sons.

Bridge, J. S., and Mackey, S. D. (1993). A revised alluvial stratigraphy model. Alluvial sedimentation, 317-336.

Bridge, J. S., and Tye, R. S. (2000). Interpreting the dimensions of ancient fluvial channel bars, channels, and channel belts from wireline-logs and cores. AAPG bulletin 84, 1205-1228.

Catuneanu, O. (2006). Principles of sequence stratigraphy. Amsterdam; Boston: Elsevier.

Cecil, C. B. (1990). Paleoclimate controls on stratigraphic repetition of chemical and siliciclastic rocks. Geology 18, 533-536.

Cecil, C. B. (2003). Climate controls on the stratigraphy of a Middle Pennsylvanian cyclothem in North America. Available at: http://archives.datapages.com/data/sepm_sp/SP77/Climate_Controls_on_the_Stratigraph y.pdf [Accessed January 17, 2017].

Cecil, C. B. (2013). An overview and interpretation of autocyclic and allocyclic processes and the accumulation of strata during the Pennsylvanian-Permian transition in the central Appalachian Basin, USA. International Journal of Coal Geology 119, 21-31. doi:10.1016/j.coal.2013.07.012. 
Cecil, C. B., Brezinski, D. K., and Dulong, F. (2004). The Paleozoic record of changes in global climate and sea level: Central Appalachian Basin. Geology of the National Capital Region-Field Trip Guidebook: US Geological Survey Circular 1264, 77-133.

Cecil, C. B., and Dulong, F. T. (2003). Precipitation models for sediment supply in warm climates. SEPM Society for Sedimentary Geology 77, 21-27.

Cecil, C. B., Dulong, F. T., West, R. R., Stamm, R., Wardlaw, B., and Edgar, N. T. (2003). "Climate controls on the stratigraphy of a Middle Pennsylvanian cyclothem in North America," in Climate Controls on Stratigraphy, eds. C. B. Cecil and N. T. Edgar (SEPM Society for Sedimentary Geology), 0. doi:10.2110/pec.03.77.0151.

Cecil, C. B., Stanton, R. W., Neuzil, S. G., Dulong, F. T., Ruppert, L. F., and Pierce, B. S. (1985). Paleoclimate controls on late Paleozoic sedimentation and peat formation in the central Appalachian Basin (USA). International Journal of Coal Geology 5, 195-230.

Chamberlin, E. P., and Hajek, E. A. (2015). Interpreting paleo-avulsion dynamics from multistory sand bodies. Journal of Sedimentary Research 85, 82-94.

Currie, B. S. (1997). Sequence stratigraphy of nonmarine Jurassic-Cretaceous rocks, central Cordilleran foreland-basin system. GSA Bulletin 109, 1206-1222. doi:10.1130/00167606(1997)109<1206:SSONJC>2.3.CO;2.

Davidson, S. K., and Hartley, A. J. (2010). Towards a Quantitative Method for Estimating Paleohydrology from Clast Size and Comparison with Modern Rivers. Journal of Sedimentary Research 80, 688-702.

Davis, J. C., and Sampson, R. J. (1986). Statistics and data analysis in geology. Wiley New York et al.

DeCelles, P. G., Langford, R. P., and Schwartz, R. K. (1983). Two new methods of paleocurrent determination from trough cross-stratification. Journal of Sedimentary Research 53, 629642.

DiMichele, W. A. (2013). Wetland-dryland vegetational dynamics in the Pennsylvanian ice age tropics. International Journal of Plant Sciences 175, 123-164.

DiMichele, W. A., Cecil, C. B., Montañez, I. P., and Falcon-Lang, H. J. (2010). Cyclic changes in Pennsylvanian paleoclimate and effects on floristic dynamics in tropical Pangaea. International Journal of Coal Geology 83, 329-344.

Donaldson, A. C., and Shumaker, R. C. (1981). Late Paleozoic molasse of central Appalachians. Sedimentation and tectonics in alluvial basins: Geological Association of Canada Special Paper 23, 99-124. 
Eble, C. F. (2002). Palynology of late Middle Pennsylvanian coal beds in the Appalachian Basin. International Journal of Coal Geology 50, 73-88.

Ethridge, F. G., and Schumm, S. A. (1977). Reconstructing paleochannel morphologic and flow characteristics: methodology, limitations, and assessment.

Ettensohn, F. R. (2005). "5. The sedimentary record of foreland-basin, tectophase cycles: Examples from the Appalachian Basin, USA," in Developments in Sedimentology Cyclic Development of Sedimentary Basins., eds. J. M. Mabessoone and V. H. Neumann (Elsevier), 139-172. doi:10.1016/S0070-4571(05)80007-X.

Ettensohn, F. R. (2008). "Chapter 4 The Appalachian Foreland Basin in Eastern United States," in Sedimentary Basins of the World The Sedimentary Basins of the United States and Canada., ed. A. D. Miall (Elsevier), 105-179. Available at: http://www.sciencedirect.com/science/article/pii/S187459970800004X [Accessed January 3, 2017].

Falcon-Lang, H. J. (2004). Pennsylvanian tropical rain forests responded to glacial-interglacial rhythms. Geology 32, 689-692. doi:10.1130/G20523.1.

Falcon-Lang, H. J., and Dimichele, W. A. (2010). What happened to the coal forests during Pennsylvanian glacial phases? Palaios 25, 611-617.

Fielding, C. R., and Alexander, J. (1996). Sedimentology of the Upper Burdekin River of North Queensland, Australia - an example of a tropical, variable discharge river. Terra Nova 8, $447-457$.

Fielding, C. R., Allen, J. P., Alexander, J., and Gibling, M. R. (2009). Facies model for fluvial systems in the seasonal tropics and subtropics. Geology 37, 623-626.

Gibling, M. R. (2006). Width and thickness of fluvial channel bodies and valley fills in the geological record: a literature compilation and classification. Journal of sedimentary Research 76, 731-770.

Gibling, M. R., Davies, N. S., Falcon-Lang, H. J., Bashforth, A. R., DiMichele, W. A., Rygel, M. C., et al. (2014). Palaeozoic co-evolution of rivers and vegetation: a synthesis of current knowledge. Proceedings of the Geologists' Association 125, 524-533.

Greb, S. F., Pashin, J. C., Martino, R. L., and Eble, C. F. (2008). Appalachian sedimentary cycles during the Pennsylvanian: Changing influences of sea level, climate, and tectonics. Geological Society of America Special Papers 441, 235-248. doi:10.1130/2008.2441(16).

Haq, B. U., and Schutter, S. R. (2008). A chronology of Paleozoic sea-level changes. Science $322,64-68$. 
Holbrook, J., and Schumm, S. A. (1999). Geomorphic and sedimentary response of rivers to tectonic deformation: a brief review and critique of a tool for recognizing subtle epeirogenic deformation in modern and ancient settings. Tectonophysics 305, 287-306.

Holbrook, J., Scott, R. W., and Oboh-Ikuenobe, F. E. (2006). Base-level buffers and buttresses: a model for upstream versus downstream control on fluvial geometry and architecture within sequences. Journal of Sedimentary Research 76, 162-174.

Holbrook, J., and Wanas, H. (2014). A fulcrum approach to assessing source-to-sink mass balance using channel paleohydrologic paramaters derivable from common fluvial data sets with an example from the Cretaceous of Egypt. Journal of Sedimentary Research 84, 349-372.

Kosanke, R. M., and Cecil, C. B. (1996). Late Pennsylvanian climate changes and palynomorph extinctions. Review of Palaeobotany and Palynology 90, 113-140. doi:10.1016/00346667(95)00027-5.

Leclair, S. F. (2002). Preservation of cross-strata due to the migration of subaqueous dunes: an experimental investigation. Sedimentology 49, 1157-1180.

Leclair, S. F., and Bridge, J. S. (2001). Quantitative interpretation of sedimentary structures formed by river dunes. Journal of Sedimentary Research 71, 713-716.

Leeder, M. R. (1993). Tectonic controls upon drainage basin development, river channel migration and alluvial architecture: implications for hydrocarbon reservoir development and characterization. Geological Society, London, Special Publications 73, 7-22. doi:10.1144/GSL.SP.1993.073.01.02.

Leeder, M. R. (2009). "On the Interactions between Turbulent Flow, Sediment Transport and Bedform Mechanics in Channelized Flows," in Modern and Ancient Fluvial Systems (Wiley-Blackwell), 3-18. doi:10.1002/9781444303773.ch1.

Lin, W., and Bhattacharya, J. P. (2017). Estimation of Source-To-Sink Mass Balance By A Fulcrum Approach Using Channel Paleohydrologic Parameters of the Cretaceous Dunvegan Formation, Canada. Journal of Sedimentary Research 87, 97-116. doi:10.2110/jsr.2017.1.

Miall, A. (2014). Fluvial Depositional Systems. Cham: Springer International Publishing doi:10.1007/978-3-319-00666-6.

Miall, A. D. (1996). The geology of fluvial deposits. Springer.

Montañez, I. P., McElwain, J. C., Poulsen, C. J., White, J. D., DiMichele, W. A., Wilson, J. P., et al. (2016). Climate, pCO2 and terrestrial carbon cycle linkages during late Palaeozoic glacial-interglacial cycles. Nature Geoscience 9, 824. 
Pedregosa, F., Varoquaux, G., Gramfort, A., Michel, V., Thirion, B., Grisel, O., et al. (2011). Scikit-learn: Machine Learning in Python. Journal of Machine Learning Research 12, $2825-2830$.

Peppers, R. A. (1996). Palynological correlation of major Pennsylvanian (Middle and Upper Carboniferous) chronostratigraphic boundaries in the Illinois and other coal basins. Geological Society of America.

Plink-Björklund, P. (2015). Morphodynamics of rivers strongly affected by monsoon precipitation: Review of depositional style and forcing factors. Sedimentary Geology 323, 110-147. doi:10.1016/j.sedgeo.2015.04.004.

Python Python Software Foundation. Python.org. Available at: https://www.python.org/ [Accessed June 28, 2019].

Rubin, D. M., and McCulloch, D. S. (1980). Single and superimposed bedforms: a synthesis of San Francisco Bay and flume observations. Sedimentary Geology 26, 207-231.

Sak, P. B., McQuarrie, N., Oliver, B. P., Lavdovsky, N., and Jackson, M. S. (2012). Unraveling the central Appalachian fold-thrust belt, Pennsylvania: The power of sequentially restored balanced cross sections for a blind fold-thrust belt. Geosphere 8, 685-702.

Schumm, S. A. (1968). River adjustment to altered hydrologic regimen-Murrumbidgee River and paleochannels, Australia. US Govt. Print. Off.

Schumm, S. A. (1981). Evolution and response of the fluvial system, sedimentologic implications.

Schumm, S. A. (1988). Variability of the fluvial system in space and time. Scales and global change, 225-250.

Shanley, K. W., and McCabe, P. J. (1994). Perspectives on the sequence stratigraphy of continental strata. AAPG bulletin 78, 544-568.

Stubbs, D. G. (2018). A Sequence Stratigraphic Analysis of the Allegheny Group (Middle Pennsylvanian), Southeast Ohio. Available at: Masters Thesis, Ohio University.

Tabor, N. J., and Montanez, I. P. (2002). Shifts in late Paleozoic atmospheric circulation over western equatorial Pangea: Insights from pedogenic mineral $\delta 180$ compositions. Geology 30, 1127-1130.

Tabor, N. J., and Poulsen, C. J. (2008). Palaeoclimate across the Late Pennsylvanian-Early Permian tropical palaeolatitudes: a review of climate indicators, their distribution, and relation to palaeophysiographic climate factors. Palaeogeography, Palaeoclimatology, Palaeoecology 268, 293-310. 
Zhang, Y., Kimberg, D. Y., Coslett, H. B., Schwartz, M. F., and Wang, Z. (2014). Support vector regression based multivariate lesion-symptom mapping. in 2014 36th Annual International Conference of the IEEE Engineering in Medicine and Biology Society (IEEE), 5599-5602. 


\section{Chapter 3}

Stratigraphy framework for the Sequence Stratigraphic Analysis of Fluvial Depositional Systems: Example from the Middle Pennsylvanian Allegheny Formation (MPAF) South-Central, West Virginia.

Oluwasegun Abatan $^{1}$, Amy Weislogel ${ }^{1}$, Bascombe Blake ${ }^{2}$

1) West Virginia University

2) West Virginia Geologic and Economic Survey 


\section{$1 \quad$ Abstract}

Stratigraphic analysis of fluvial deposits of the Middle Pennsylvanian Allegheny Formation (MPAF) involved the correlation of genetically related deposits via genetically related hiatus and unconformity bounding surfaces. The MPAF of West Virginia with its extensively mapped, regionally persistent coal beds with strong biostratigraphic control and widespread subsurface characterization, is ideal for identifying related stratal packages using chronologically significant unconformity and hiatus of its channel and floodplain environments. The Lower Kittanning and Middle Kittanning coal beds are regionally extensive coal beds that were used as marker beds for correlation of the sandstone members and floodplain deposits of the MPAF using core and outcrop data in central and northern West Virginia. In order to determine the lateral extent and sedimentary character of individual lithosome within the MPAF, sequence stratigraphic correlation of the MPAF was performed using sequence stratigraphic boundaries defined by coal bed underclays and erosive bases of incised fluvial channels, combined with association of high accommodation and low accommodation system tracts interpreted from facies architecture between bounding surfaces. The stacking pattern of MPAF sequences five low to high accommodation sequences in the MPAF based on the integration of key bounding surfaces with detailed facies analysis. Accommodation succession showed that the upper MPAF deposition occurred within higher accommodation conditions, which may have been caused by increased base-level over time. A comparison of drivers in base-level changes and sedimentologic infilling in the MPAF shows that while glacio-eustasy and tectonism control basin-wide base-level and accommodation succession, paleoclimate influenced sedimentary infilling of available accommodation.

\section{Introduction}

Sequence stratigraphy, a sub-discipline of stratigraphy, allows for the sub-division of rock bodies in relation to the time or age of deposition. Sequence stratigraphic sub-divisions group rock bodies based on genetically-related facies that are bounded above and below by stratigraphic discontinuities (Salvador, 1994; Van Wagoner et al., 1988). In contrast, lithostratigraphy groups strata of similar lithology, regardless of the age of deposition. The result of lithostratigraphic correlation is that coeval, genetically-related lithofacies may be grouped together, but it may also group rocks that are not chronologically related (Holbrook and Bhattacharya, 2012; Mitchum et al., 1977; Strong and Paola, 2008; Wheeler and Mallory, 1956). Therefore, lithostratigraphic correlation may result in an inaccurate reconstruction of the depositional system process evolution (Bhattacharya, 2011; Holbrook and Bhattacharya, 2012; Van Wagoner et al., 1988).

Several researchers (e.g., Catuneanu et al., 2006; Miall, 2014; Mitchum et al., 1977; Wagoner et al., 1987) have used sequence stratigraphy to accurately depict the evolution of a variety of depositional systems, including fluvial depositional systems. The development of an accurate sequence stratigraphic framework is especially important for fluvial strata because fluvial incision can place younger fluvial deposits at a lower stratigraphic level than older fluvial 
deposits. This could chronologically invert aspects of a fluvial depositional model as well as generate lithostratigraphic correlation of genetically unrelated deposits. Recent advances in sequence stratigraphy, such as the recognition of accommodation successions (e.g., Neal and Abreu, 2009), have improved the application of sequence stratigraphic modeling to the interpretation of depositional systems and their evolution through time. However, most of these advances have been made in marginal marine and marine depositional systems, due to the relative ease of locating a regional datum which is essential for accurate correlation (e.g., maximum flooding surface, Van Wagoner et al., 1988). However, it may be possible to develop a sequence stratigraphic framework in a fluvial-dominated system based on vertical facies stacking patterns and identification of accommodation successions (Martino, 2016; Neal and Abreu, 2009) which is a critical step in comprehensive correlation of genetically-related basin-fill units from source to sink environments (i.e., fluvial to marine environments; Blum and Törnqvist, 2000; Neal and Abreu, 2009; Bhattacharya, 2011).

Fundamentally, sequence stratigraphic models evaluate the depositional products of a sedimentary system as a function of the ratio between accommodation and sediment supply. Accommodation is the space within a depositional basin that is available for sediments to fill (Catuneanu, 2006). The effective accommodation of a fluvial system, which is also referred to as stratigraphic base level, is defined by the height of the water level in a bank-full fluvial channel (Blum and Törnqvist, 2000). Therefore, the magnitude of accommodation is recorded by the erosional scour surfaces and the thickness, facies and stacking pattern of the preserved, overlying fluvial facies (Currie, 1997; Catuneanu, 2006; Miall, 2014). Widespread channel incision is attributed to negative accommodation; fluvial deposits formed during periods of negative accommodation are called degradational system tracts (Catuneanu, 2006; Currie, 1997; Holbrook and Bhattacharya, 2012; Miall, 1996). Amalgamated channel bodies often occur as infill overlying these scoured surfaces, and reflect fluvial system evolution during periods of low accommodation, high sediment supply, and significant sediment bypass, and may be part of the landward equivalent of the marine eustatic falling stage, low stand and/or early transgressive system tracts (Bhattacharya, 2011; Catuneanu, 2006; Currie, 1997; Holbrook and Bhattacharya, 2012; Shanley and McCabe, 1994). During periods of high accommodation and high sediment supply, isolated channels containing fully preserved channel fill successions are more likely to form; deposits of this fluvial system are assigned to the aggradational system tract and are most likely the landward equivalent of the most rapid period of sea-level rise in the transgressive system tract (Miall, 1996; Currie, 1997; Catuneanu, 2006). Fluvial environments characterized by coal preservation can form during positive accommodation or even negative accommodation, such as the case with domed peat deposit, and low clastic sediment input and thus they are part of the aggradational fluvial system (Cecil, 1990; DiMichele, 2013).

Accommodation changes in fluvial systems have commonly been attributed to allogenic drivers, including eustasy, tectonism, and climate/precipitation, which also influences sediment flux (Cecil et al., 2003; Holbrook and Schumm, 1999; Miall, 2014; Miall and Blakey, 2008), with recent studies indicating that climate and tectonic processes are the dominant allogenic controls on accommodation in basin proximal fluvial systems (Bhattacharya, 2011; Blum et al., 2013; Holbrook and Bhattacharya, 2012). Martino (2004, 2016) was able to correlate terrestrial and coastal fluvial depositional environments in the Middle-Upper Pennsylvanian Conemaugh 
Formation that overlies the Allegheny Formation, demonstrating eustatic control over base-level and accommodation in coastal fluvial environments whereas tectonic and climatic processes controlled accommodation and accumulation of the more proximal terrestrial fluvial environments. Tectonic processes primarily create accommodation through subsidence, and lithosphere processes driving subsidence operate over long time intervals ( $1-2$ million yrs), except for uplift due to thrusting which may operate at a higher frequency of $10-100 \mathrm{Kyr}$. (Belt and Lyons, 1989; Chesnut Jr, 1994; Tankard, 1986). Similarly, eustatic processes, in particular, shoreline transgression which controls accommodation, may also occur at over shorter, Milankovitch time scales of 10,000 - 100,000 (Blum and Törnqvist, 2000; Miall, 2014). Paleoclimatic processes, such as precipitation patterns which affect vegetation and hydrology of fluvial depositional systems, may also vary over Milankovitch time-scales, but may also occur over even shorter periods (decadal to millennial). In summary, overall paleoclimate and tectonic controls can elicit a response from the proximal fluvial depositional systems over shorter time scales than eustatic controls (Blum and Törnqvist, 2000; Holbrook et al., 2006; Miall, 2014). Recently, other workers (e.g., Wilkinson et al., 1998; Hajek and Straub, 2017) have disputed allogenic drivers as the dominant control on accommodation and instead suggested that regional autogenic processes that operate over decadal to millennial time-scales (e.g., channel migration and avulsion) are primarily responsible for the repetitive development of accommodation that preserve cyclic succession of lithologies termed cyclothems. Therefore, proximal fluvial depositional sedimentation patterns represent the integration of autogenic controls along with paleoclimate and tectonic allogenic controls.

The Middle Pennsylvanian Allegheny Formation (MPAF) is a succession of fluvio-deltaic cyclothems in the Alleghenian foreland which have been attributed to allogenic forcing by highfrequency transgression-regressions eustatic cycles (Belt et al., 2011; Donaldson and Shumaker, 1981; Ferm, 1970; Ferm and Weisenfluh, 1989; Heckel, 2008; Wanless and Shepard, 1936). However, the MPAF cyclothems reflect evidence for variable accommodation throughout stratigraphic development, which has been attributed to paleoclimate and tectonic allogenic controls (Belt and Lyons, 1989; Cecil, 1990; Cecil et al., 2003b; Ettensohn, 2004, 2005, 2008; Blake and Beuthin, 2008; DiMichele et al., 2010; Falcon-Lang and Dimichele, 2010). Middle Pennsylvanian marine deposits correlated across the central Appalachian basin from outcrop and core data aided in delineating paleo-coastal boundary during the deposition of MPAF. Facies architecture and accommodation succession analysis interpreted from the MPAF deposits provide an opportunity to differentiate controls on accommodation during the deposition of the MPAF. This study presents a sequence stratigraphic framework using the genetically-related surfaces of floodplain paleosols and channel erosional bases to divide the MPAF in sequences. Evolution of accommodation during MPAF accumulation and the evolution of fluvial channel frequency and channel body thickness were determined from detailed sequence stratigraphic characterization of MPAF outcrop data. The frequency and stacking patterns of the sequence stratigraphic cycles can be used to identify possible drivers of stratal architecture development and estimate the dominant controls on deposition in the fluvial system. Results will test the validity of the cyclothem model as applied to Carboniferous strata of the Appalachian basin.

\section{Fluvial Sequence Stratigraphy Background}


Fluvial stratigraphy has been defined based on the allogenic and autogenic processes that influence the fluvial stratigraphic base-level and the resulting accommodation and the nature of sedimentary fill within the fluvial depositional system (Bridge and Leeder, 1979; Currie, 1997; Holbrook and Bhattacharya, 2012; Shanley and McCabe, 1994; Wright and Marriott, 1993). Tectonic subsidence and eustasy are dominant drivers on fluvial base-level and accommodation, while paleoclimate is a major control on sedimentary infill of the fluvial basin (Bridge and Leeder, 1979; Shanley and McCabe, 1994). During base-level fall, accommodation decreases leading to the formation of lowstand system tracts characterized by widespread channel incision and amalgamated channel sands, and well-developed paleosols (Bridge and Leeder, 1979; Shanley and McCabe, 1994; Wright and Marriott, 1993). During base-level rise, the fluvial depositional system generally aggrades and accumulates abundant floodplain sediment along with isolated channel sandstones. Fluvial deposits that accumulated during the base-level rise are referred to as transgressive and highstand system tracts and are characterized by isolated channel deposits and abundant floodplain deposition (Currie, 1997; Shanley and McCabe, 1994; Wright and Marriott, 1993). Bridge and Leeder (1979) using numerical and flume models, showed that fluvial channel belts and floodplains are genetically related depositional environments that often remain in a fixed physiographic position unless there is a regional change in accommodation likely caused by tectonic subsidence.

Recent studies combined accommodation succession modeling of fluvial depositional systems with facies architectural analysis of fluvial deposits to interpret depositional conditions of high accommodation and low accommodation depositional cycles (Allen et al., 2011; Bhattacharya, 2011; Blum et al., 2013; Blum and Törnqvist, 2000; Holbrook and Bhattacharya, 2012; Lin et al., 2019; Neal and Abreu, 2009). The stratigraphic base-level of a fluvial depositional system defines the upper limits to deposition which is represented by the level of water in the fluvial depositional system (Blum and Törnqvist, 2000; Wheeler, 1964). The high accommodation system tract (HAST) is deposited when the stratigraphic base-level is high in the fluvial depositional system. The deposits are characterized by sandstone and mudrock within the channel and mainly mudrocks in the floodplain (Catuneanu, 2003; Holbrook and Bhattacharya, 2012). The channel mudrock to sand ratio are highest in HAST. Channel sandstones of the HAST are more likely to have formed single-thread systems and generate thicker preserved sandstone channel-fill successions than the low accommodation system tract (Shanley and McCabe, 1994; Currie, 1997). HAST deposits in the floodplain may include coal formed from peat which accumulated in adjacent swamps. Increasing the stratigraphic base-level of the fluvial depositional system may result in the formation of a lake (Bridge, 2009; Miall, 1996; Pechacek, 2018; Wright and Marriott, 1993). The lacustrine deposits may be limestone or laterally continuous tabular massive sandstone deposits. Continued increases in stratigraphic base-level may result in the drowning out of accumulated peat and/ or limestone factory, resulting in the deposition of shale over coal swamps or limestone (Cecil, 1990; Donaldson et al., 1985; Wadsworth et al., 2003). The stratigraphic base-level may also rise leading to flood water levels which results in frequent flooding in the paleovalley. Flooding of the fluvial system results in widespread shale and other mudrock deposits in both channels and floodplain environments in the fluvial depositional system (Miall, 1996). 
The low accommodation system tract (LAST) is deposited when the stratigraphic baselevel is low in the fluvial depositional system. The stratigraphic base-level within the channel belt may drop to levels that initiate channel incision within the fluvial depositional system deposits, including channel belts and floodplain, resulting in multistory channel fills bounded by erosional surfaces and erosionally truncated floodplain deposits (Holbrook and Bhattacharya, 2012; Neal and Abreu, 2009). The multistory channel fill of LAST deposits may lack preservation of floodplain associated with an individual story as a result of the low-base level and erosion from fluvial reworking. Where floodplains are preserved, they are well-drained and contain well-developed paleosols characterized by slickensides, and/ or caliche rich mudrock (Allen et al., 2014; Atkins, 2016; Cecil and Englund, 1989; DiMichele, 2013; Fielding et al., 2009; Kraus, 1999; Wright and Marriott, 1993). The LAST channel deposits are characterized by amalgamated sandstone bodies with degrading erosional base (Currie, 1997; Lin et al., 2019; Neal and Abreu, 2009; Shanley and McCabe, 1994; Wright and Marriott, 1993). The ratio of channel mudrock to sand is lowest, i.e. sandstone is more abundant while mudrock deposits are lacking in the LAST.

\section{Geological Setting and Previous Work}

The MPAF is a clastic wedge deposited in the Alleghenian foreland basin formed from the collision of Gondwana and Laurussia during the final closure of the Rheic Ocean (Fig. 3-1, Fig. 3-2) (Ettensohn, 2008). The resulting foreland basin formed a broad shallow basin west of the highlands uplifted along the orogenic front (Donaldson and Shumaker, 1981; Ettensohn, 2005, 2008). A combination of tectonic, climatic and glacio-eustatic processes controlled Middle Pennsylvanian erosion, transportation, and deposition of sediments that overfilled the foredeep producing widespread deposition across the basin and adjacent continental interior (Fig. 3-2) (Donaldson and Shumaker, 1981; Ettensohn, 2008). Paleogeographic reconstructions suggest the most proximal paleoshoreline during the MPAF deposition extended from present-day eastsoutheastern Ohio to southwestern Pennsylvania, approximately following the West Virginia Ohio - Pennsylvania border (Fig. 3-1; Ferm, 1970; Bailey, 1981; Ferm and Weisenfluh, 1989; Belt et al., 2011; Stubbs, 2018).

The MPAF is characterized by up to $130 \mathrm{~m}$ thick, sandstone and mudrock units with sporadic coal and limestone, which represent the deposits of a westward prograding fluvialdominated depositional system (Donaldson and Shumaker, 1981; Cecil et al., 2003; Ettensohn, 2008). The MPAF coals beds from oldest to youngest are: No. 5 Block, Upper No. 5 Block, Lower Kittanning, Middle Kittanning, Upper Kittanning, Lower Freeport, and Upper Freeport (Arkle Jr et al., 1979; Donaldson and Shumaker, 1981; Cecil and Englund, 1989). Coal beds of the MPAF have been used in several eustatic and paleoclimatic models to illustrate allogenic controls on cyclothems (Cecil, 1990; Cecil et al., 2003; DiMichele, 2013; Falcon-Lang and Dimichele, 2010). The MPAF clastics and interbedded coal seams were termed cyclothems because the development of coal peat swamps was attributed to cyclic changes in sea levels during glacial-interglacial fluctuations of the Late Paleozoic Ice Age (Cecil, 1990; Cecil et al., 1993; DiMichele et al., 2010; Greb et al., 2008). Coal deposition occurred during glacial maxima and associated lowstand; peat accumulation was attributed to base-level rise driven by eustasy in a humid environment. However miospores, ash and sulfur content observed in MPAF coals 
suggest that some of the coal beds were deposited in a seasonally wet-dry climate (Cecil, 1990; DiMichele et al., 2010; Eble, 2002). Other MPAF deposits that have been used as paleoclimatic proxies include non-marine limestone and genetically related calcic paleosols which are associated with seasonally wet-dry climate (Cecil, 1990; DiMichele et al., 2010). Some of the floodplain mudrock deposits associated with the Upper Kittanning and Upper Freeport coal beds contain calcareous inclusions which have been attributed to deposition under dry conditions in a wet-dry seasonal climate (DiMichele et al., 2010; Falcon-Lang and Dimichele, 2010). The dry periods are associated with periods of low base-level in the Appalachian basin which is characterized by well-developed calcareous paleosols in the floodplains environments and low accommodation and incision in the channel belts (Cecil et al., 2003; DiMichele, 2013; FalconLang and Dimichele, 2010). 


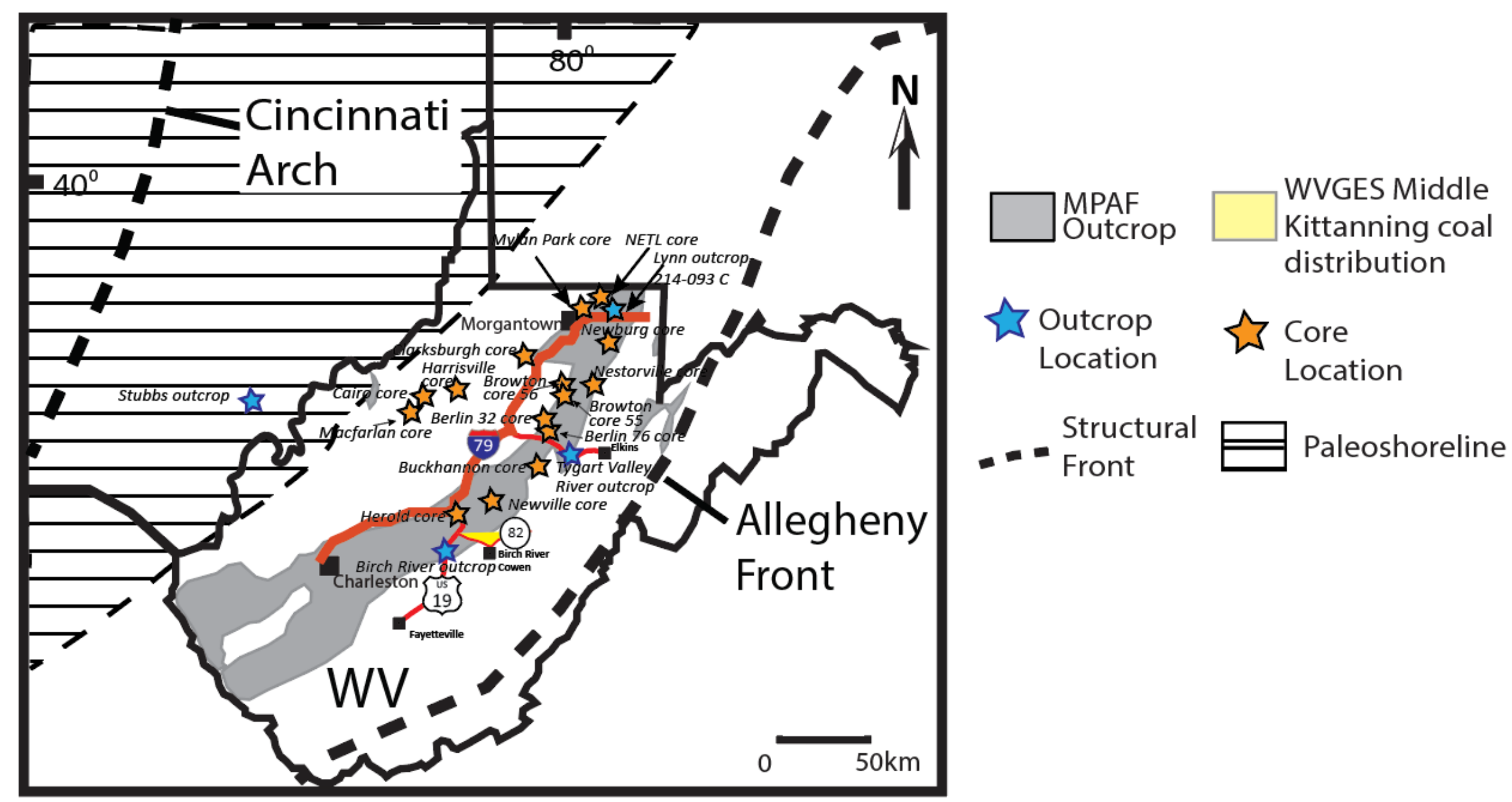

Figure 3-1: Study location, West Virginia. Gray area is MPAF outcrop. Yellow area is WVGES Middle Kittanning coal bed coal distribution. Gold stars are core locations. Blue stars are outcrop locations. Labeled locations are used in measured sections and photos. The outcrop data in Ohio is from Stubbs (2018). Shoreline modified from Blakey Maps. 
Middle Pennsylvanian climate models suggest that glacial-interglacial fluctuations influenced the position of the intertropical convergence zone (ITCZ) and associated pressure belts. Migration of the ITCZ lead to drastic changes in Appalachian basin climate, causing alternating wet to seasonally wet-dry precipitation patterns and varied rates of evapotranspiration in the Appalachian basin (Cecil et al., 2004, 2003; Cecil and Dulong, 2003; DiMichele et al., 2010). In addition, drift of Pangea led to paleolatitude shift from $10^{\circ}$ south to about $5^{\circ}$ south of the equator during the Carboniferous (Cecil et al., 2004), which may have facilitated a paleoclimate change from predominantly semi-arid conditions in the Mississippian to the predominantly humid conditions of the Middle Pennsylvanian (Cecil, 1990; Cecil et al., 2003; Ettensohn, 2008; Falcon-Lang and Dimichele, 2010; Greb et al., 2008). Other paleoclimatic models suggest that the Alleghenian orogenic highlands to the east of the basin created a rain shadow effect which substantially reduced precipitation in the basin (Ettensohn, 2008; Tabor and Poulsen, 2008).

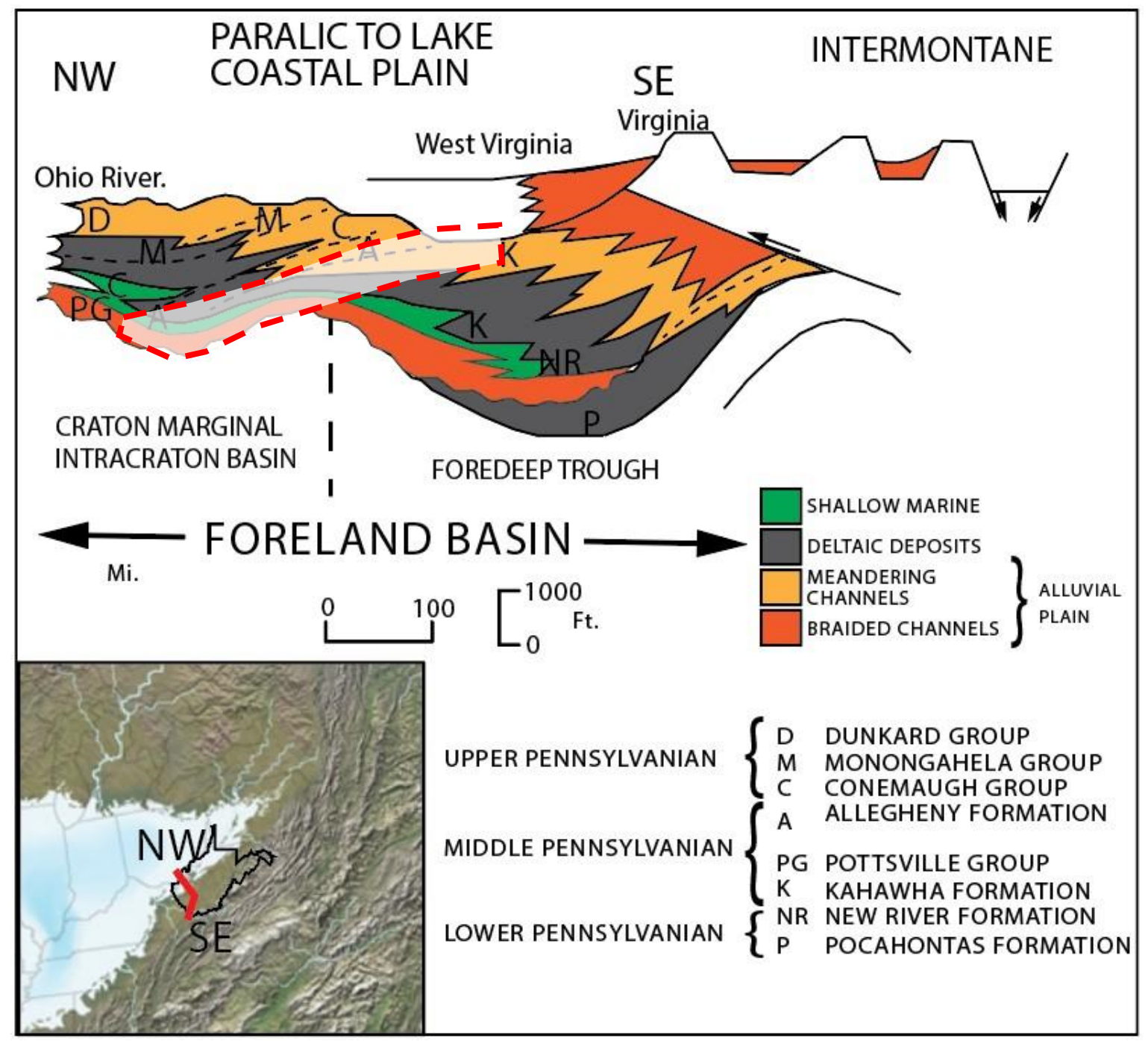


Figure 3-2: Appalachian foreland basin lithostratigraphy. MPAF is shaded area with a dashed outline. Insert is a paleogeographic map of West Virginia area during the Middle Pennsylvanian Images modified from Donaldson et al., 1985; Blakey, 2018.

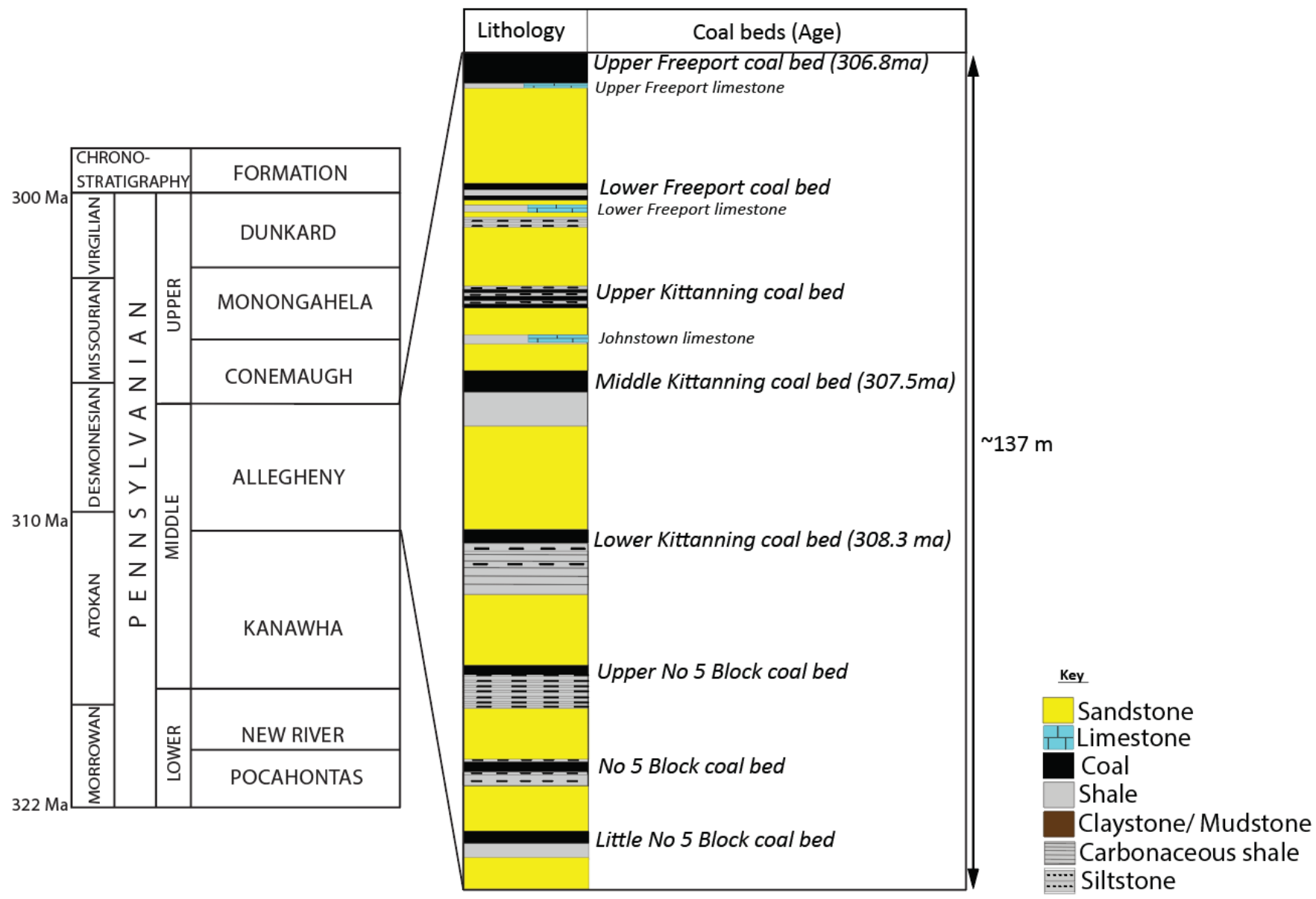

Figure 3-3: MPAF lithologic column. Modified from Blake et al. (2002), Cecil et al. (2004), and Montañez et al. (2016). Age estimates are from Montañez et al. (2016).

\section{Data and Methods}

Road cuts and cores through the MPAF in central and north-central parts of the Allegheny foreland basin were used to generate composite sedimentologic logs for sequence stratigraphic analysis. Logs were constructed using a measuring staff or ruler, Wentworth calibrated grain size card and Brunton compass in order to document lithofacies, grain size, sedimentary structures, fossils, and paleocurrents. Two extensive road-cuts along the Birch River section of US 19 and Tygart Valley section of US 33 highways in central and north-central West Virginia expose 
deposits of the MPAF (Fig. 3-1). One outcrop along interstate 68 in northern West Virginia (WVGES ID - 214-093C) which was described by geologist from the West Virginia Geologic and Economic Survey, was used in this study. The Birch River section, a nearly $500 \mathrm{~m}$-long, nearly 45 m-thick, northeast-southwest trending outcrop, constitutes the Stockton A, No. 5 Block, Upper No. 5 Block, and Lower Kittanning coal beds and associated sandstone and mudrock strata. The Tygart Valley outcrop is $\sim 750 \mathrm{~m}$-long and $\sim 40 \mathrm{~m}$-thick and comprises the Lower Kittanning, Middle Kittanning, Upper Kittanning, and Lower Freeport coals beds and associated sandstone, mudrock, and limestone strata. Uppermost parts of the outcrops were measured using data from high-quality photopan of the road-cuts where the cliff exposures were inaccessible. The Lynn outcrop is $\sim 35 \mathrm{~m}$ thick and comprises the MPAF coal beds from the Lower Kittanning to the Upper Freeport coal bed.

Fifteen cores through the MPAF, from central and north-central West Virginia, were used in the sedimentological and sequence stratigraphic analysis (Fig. 3-1, Photos of cores available in the supplementary material. click here to access supplementary material). The lithologic and sedimentologic descriptions of the cores by geologist from West Virginia Geologic and Economic Survey (WVGES) were used to supplement correlations. Most of the core data comprises of different intervals of MPAF coal beds and strata as some lithologies were absent in some of the core data. Mudrocks and coal beds were decompacted to allow for accurate interpretation of coeval deposits when correlating sequence boundaries across. Claystone, mudstone and shale were decompacted by a factor of 2 , siltstone was decompacted by a factor of 1.5 and coal beds were decompacted by a factor 10 (Fielding, 1986).

\subsection{Stratigraphic Analysis}

The MPAF was sub-divided based on coal beds, which have been extensively mapped across West Virginia using coal industry borehole data as part of the West Virginia Geologic and Economic Survey Coal Bed Mapping project (Fig. 3-1). This mapping reveals the Lower and Middle Kittanning coal beds intervals are synchronous and regionally extensive and thus were selected as datums for stratigraphic analysis (Cecil et al., 2003; Bhattacharya, 2011). Since regionally extensive coal beds are commonly deposited in areas with low gradient, they provide datums that can be used to reconstruct true stratigraphic geometry (Bhattacharya, 2011; Miall, 2014; Sahoo and Gani, 2016). The Lower Kittanning and Middle Kittanning coal beds are present in most of the outcrops and cores. The MPAF units below the Lower Kittanning coal beds were absent in most of the northern part of the study area due to an unconformity attributed to uplift along a flexural hingline (Donaldson et al., 1985). Due to this unconformity, stratigraphic analysis for this study focuses on the upper MPAF which comprises the Lower Kittanning coal beds and associated deposits.

\subsubsection{Accommodation Succession}

Accommodation succession was interpreted based on facies stacking patterns, with the prediction that facies typically coarsen upwards with reducing accommodation and fine upwards with increasing accommodation (Catuneanu, 2006; Neal and Abreu, 2009). These patterns were used to compare and correlate accommodation changes observed in the channel to accommodation changes in the floodplain. The ratio of accommodation to sediment supply (A/S) 
developed by Neal and Abreu (2009) was modified for this study. Provided that sediment supply is constant, when $\mathrm{A} / \mathrm{S}>1$, a HAST accommodation succession will form. When $\mathrm{A} / \mathrm{S}<1$ and increasing, accommodation succession is transitioning from LAST to HAST. When A/S $<1$ and decreasing, the system is transitioning from HAST to LAST. Finally, when A/S $<1$ and decreasing to negative a LAST is forming (Table 3-1). For this study, this scheme was further simplified as positive accommodation to sediment supply ratio $(+\mathrm{A} / \mathrm{S})$ to represent when fluvial stratigraphic base-level is high and hence accommodation is high (HAST), and negative accommodation to sediment supply ratio $(-\mathrm{A} / \mathrm{S})$, when fluvial stratigraphic base-level is low and accommodation is low to negative in the fluvial dominated basin (LAST; Allen et al., 2014).

The facies architecture was used to interpret the depositional environment and accommodation succession. All these combined were used to interpret HAST and LAST and ultimately interpret the stratigraphic sequence of the MPAF. The HAST and LAST of both channel and floodplain environments were identified in outcrop and core sections by depositional energy (upper to lower flow regime), grading, grain size, sand-mud ratio, channel fill architecture, floodplain facies, facies thickness, coal seam availability, the nature of paleosol and accommodation succession (Fig. 3-10; Catuneanu, 2003; Atkins, 2016). The features used to interpret the accommodation packages (HAST and LAST) are presented in Table 3-1.

\subsubsection{Bounding Surfaces}

Major stratigraphic surfaces were identified based on facies and accommodation succession include floodplain surfaces (FS), and sequence boundaries (SB). These surfaces were adapted for fluvial stratigraphy based on similar processes from coastal sequence stratigraphy (Mitchum et al., 1977; Van Wagoner et al., 1988; Pattison, 1995; Neal and Abreu, 2009). Floodplain surfaces (FS) underlie floodplain facies such as shale and overlie channel facies such as sandstones of channel bar deposits (Fig. 3-5) (Shanley and McCabe, 1994). The presence of FS represents a shift to increasing base-level and accommodation.

The sequence boundary surface (SB) develops during periods of negative accommodation, which is indicated by channel incision or non-deposition/ paleosol development on adjacent upland terraces (Greb et al., 2008; Martino, 1996). The MPAF was deposited in a predominantly humid to sub-humid setting which makes it difficult to form well-drained and well-developed paleosols commonly associated with allogenic unconformities in some floodplain settings (DiMichele, 2013; DiMichele et al., 2010; Kraus, 1999; Wright and Marriott, 1993). However, coal beds, which represent the floodplain surfaces and increasing water levels of the floodplain, overlie underclays at the top of coarsening upward facies, which are unconformities that are coeval to the unconformities represented by channel erosional surfaces (Cecil et al., 2003; Greb et al., 2008; Kraus, 1999; Martino, 2004, 2016, 1996; Wright and Marriott, 1993). Therefore, SB surfaces are represented by both channel incisions surfaces of channel sandstone packages and correlative underclays, which are interpreted as paleosols, when they occur in similar accommodation succession (Fig. 3-6 and Fig. 3-7; Wright and Marriott, 1993; Kraus, 1999; Martino, 2004, 2016; Greb et al., 2008; Neal and Abreu, 2009; Bhattacharya, 2011; Holbrook and Bhattacharya, 2012). The paleosols, which were identified by pedogenic slickensides, calcareous inclusions (where available), and root traces in some underclay deposits (Fig. 3-9), represent long-standing surfaces of exposure and non-deposition (Cecil et al., 2003; 
DiMichele, 2013; Kraus, 1999; Martino, 2004, 2016; Wright and Marriott, 1993). The SB surfaces are also represented by erosional surfaces produced by incision and are overlain by degradational fluvial channel sandstone deposits and indicate negative accommodation conditions (Fig. 3-6 and Fig. 3-7). Sequence boundaries are caused by base-level drops driven by allogenic processes, therefore the SB for the channels are interpreted as the erosional bases of channels that truncate and overlie coal beds (FS). 

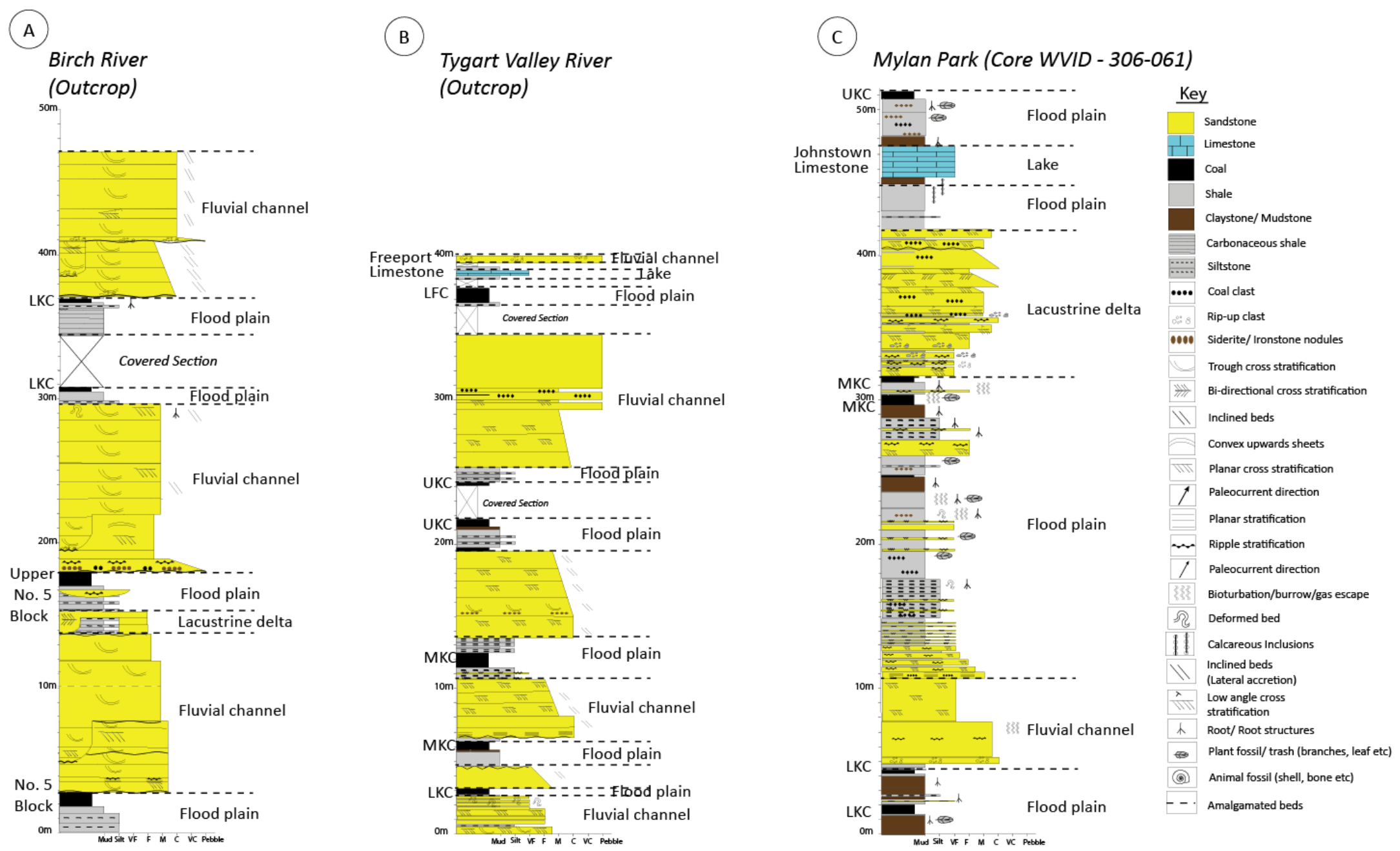

Figure 3-4: Facies association and depositional environments in undecompacted stratigraphic columns. A) Birch River measured section. B) Tygart Valley measured section. C) Mylan Park core geologic log (West Virginia Economic Survey ID 306-061). LKC = Lower Kittanning 
coal, $\mathrm{MKC}=$ Middle Kittanning coal, UKC $=$ Upper Kittanning coal, LFC $=$ Lower Freeport coal and UFC $=$ Upper Freeport coal. 


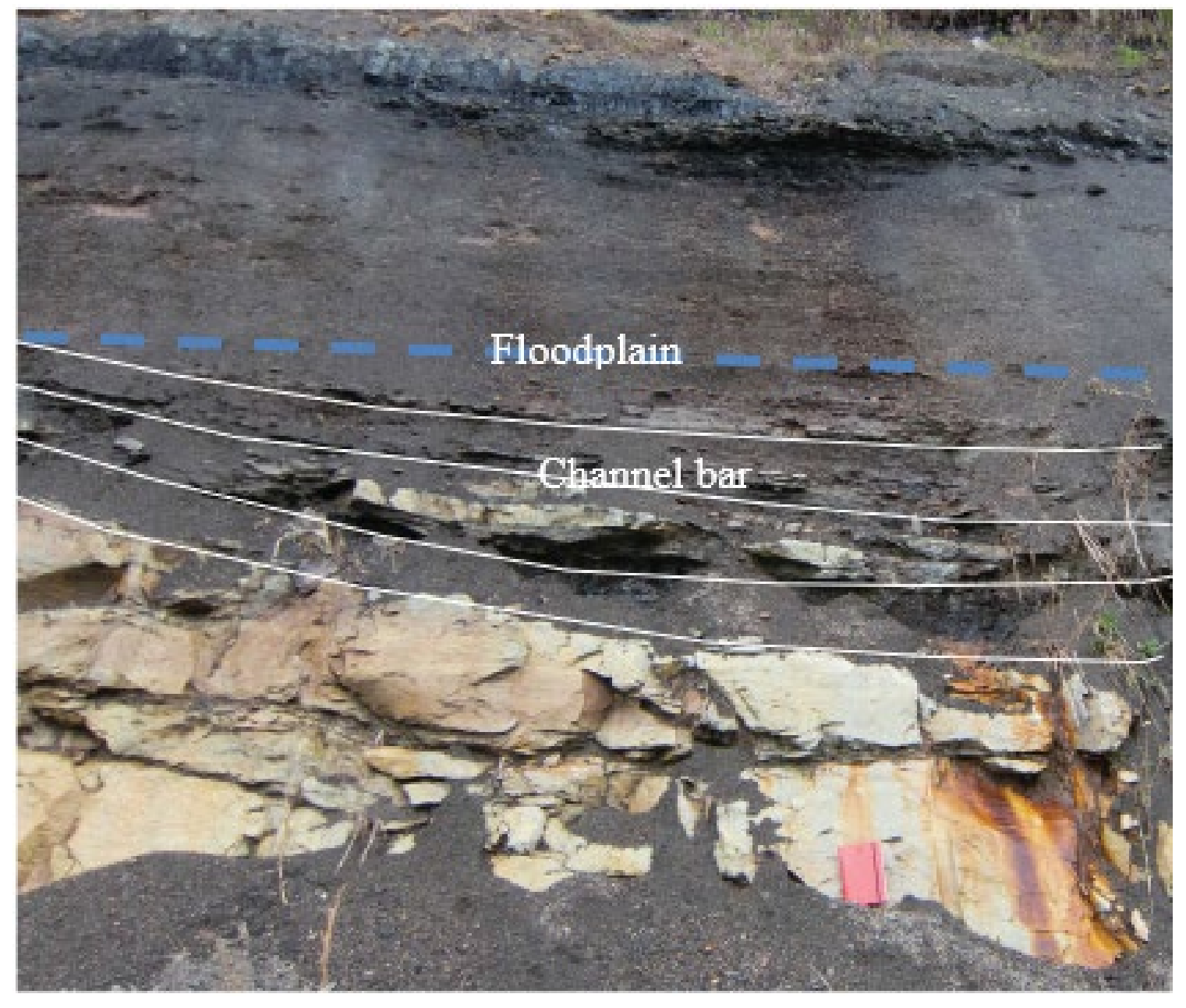

Figure 3-5: Floodplain surface (FS). The flooding surface (Blue dashed line) overlying fluvial channel fill. Tygart Valley River outcrop, WV. The book is $25 \mathrm{~cm}$. 


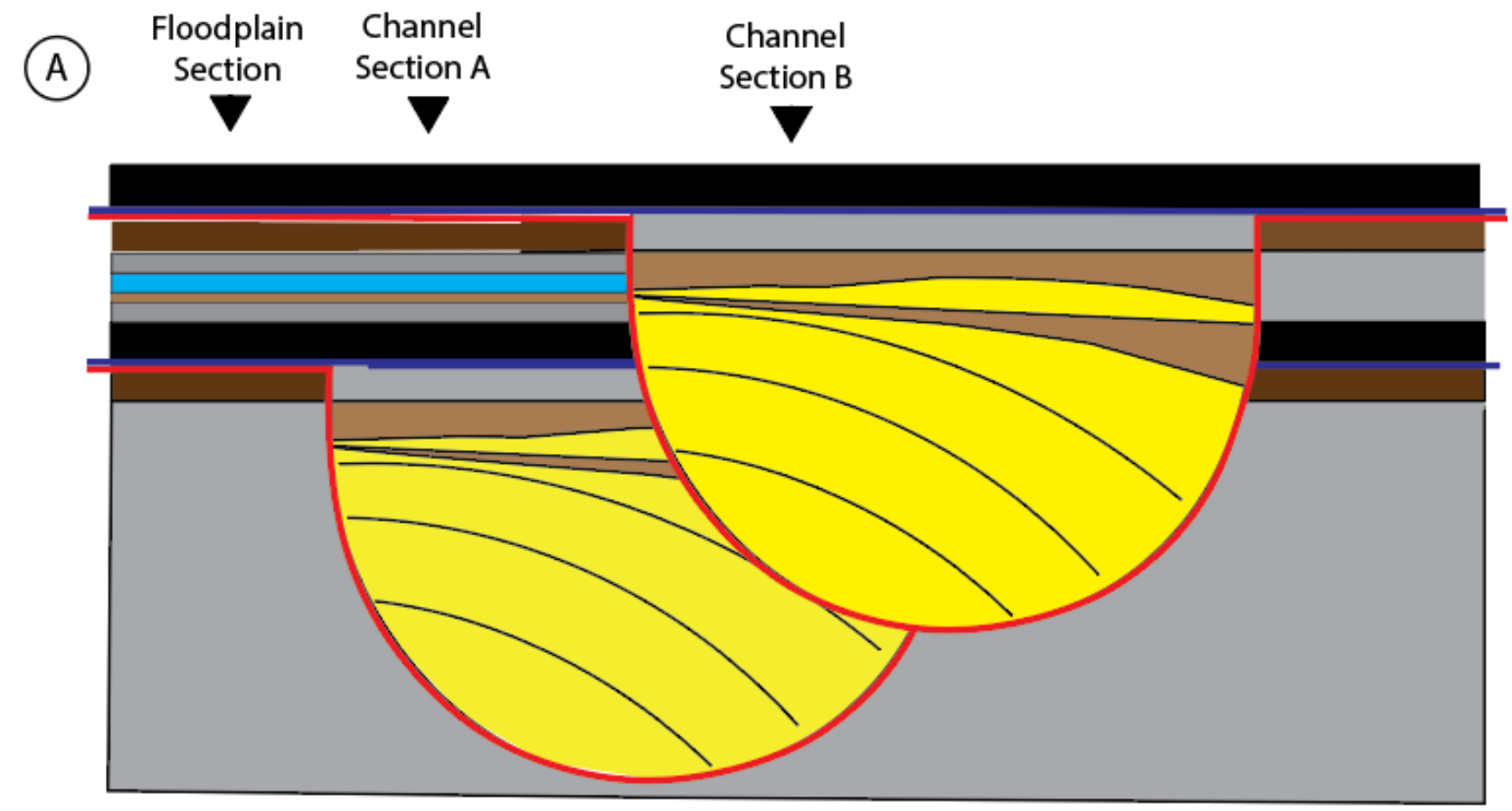

(B)

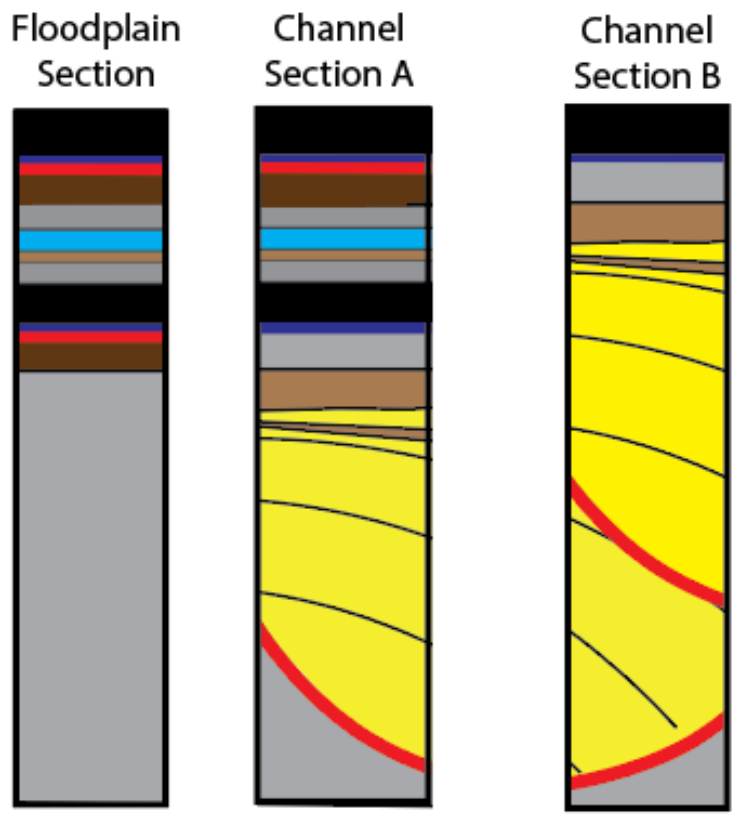

Sequence Boundary

Floodplain Surface

Sandstone Limestone Shale
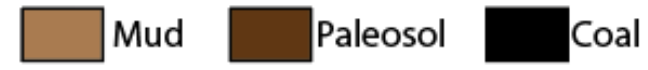

Figure 3-6: Fluvial depositional environment A) Model section of floodplain and channel depositional environments. B) Model logs of channel and floodplain sequence and floodplain surface boundaries. Note that the sequence boundary represented by the paleosol and the erosional base of the channel section in $\mathrm{A}$ is the same. 


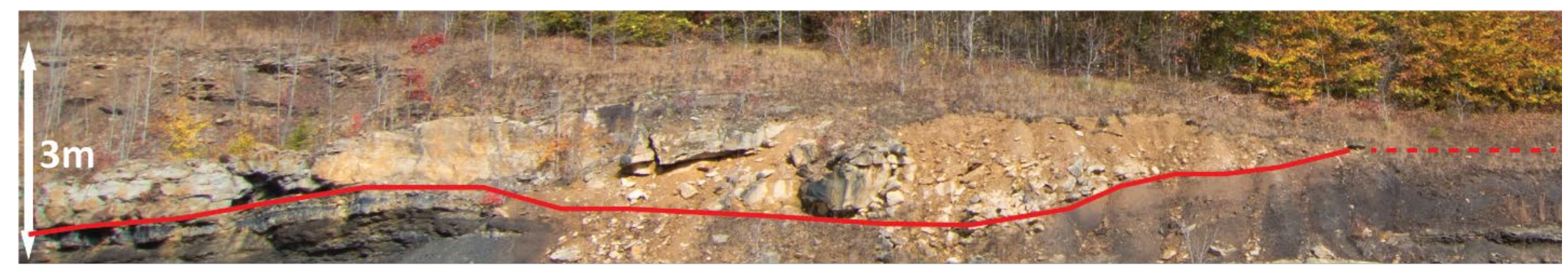

$=$ Sequence Boundary (SB)

- = = = Interpreted Sequence Boundary on floodplain paleosol (SB)

Figure 3-7: Example of sequence stratigraphic boundary interpretation in outcrop. Tygart Valley outcrop, WV. 
Sequence boundaries were identified after stratigraphic surfaces, facies architecture and accommodation succession were determined independently for each lithologic section. Sequence boundaries (SB) were used to differentiate cycles of high to low stratigraphic base levels of a sequence, while the floodplain surfaces (FS) were used to highlight the onset of flooding within a sequence. Sequence boundaries (SB) and floodplain surfaces (FS) were interpreted and correlated across the study area. Sequence boundaries were correlated across the base of channel sandstone and unconformities bounded coal bed underclays which were interpreted as paleosols. Therefore, a sedimentary log section that is characterized by predominantly floodplain deposit will have a sequence boundary at the top of the floodplain deposit, while a sedimentary log section that is characterized by predominantly channel deposits will have a SB at the bottom of the channel deposit (Fig. 3-6 and 3-11). It is possible for multiple SB to occur within a channel sandstone succession (Fig. 3-6) (Bhattacharya, 2011; Holbrook and Bhattacharya, 2012), which is often the case in more proximal fluvial channels (Bhattacharya, 2011). It is also possible to have multiple sequence boundaries in floodplain.

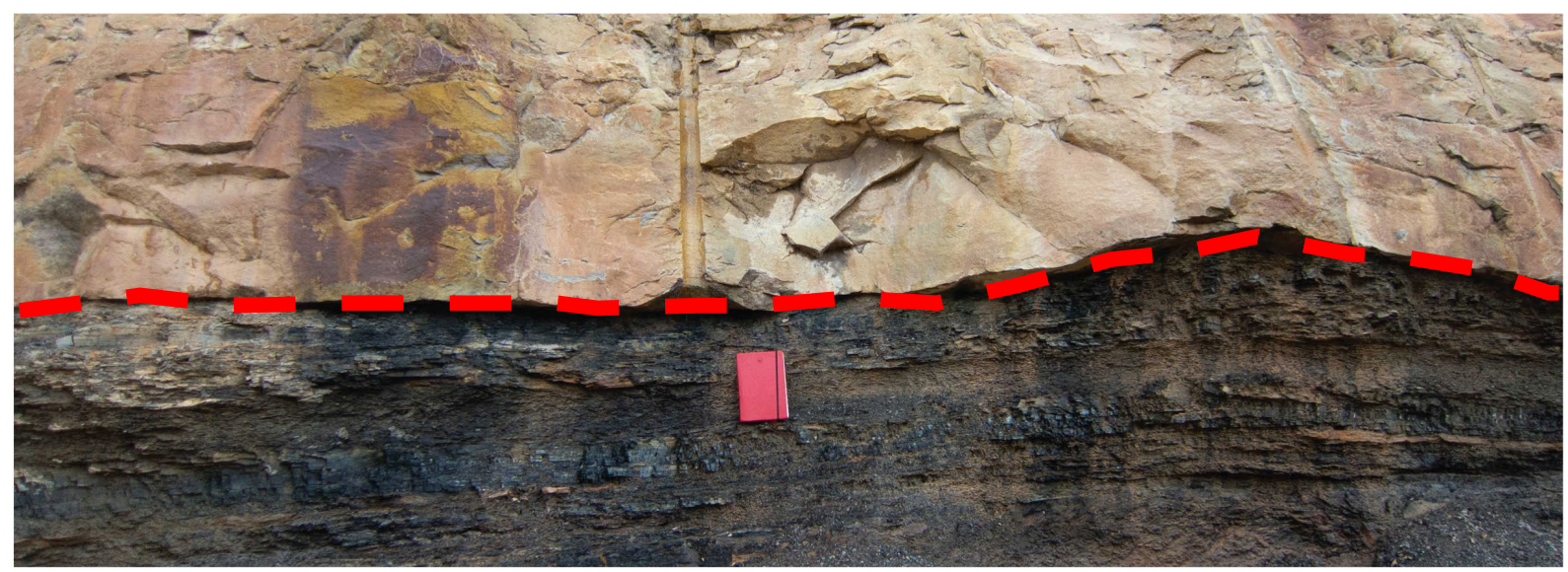

Figure 3-8: Sequence boundary (SB). Erosional surface (Red dashed line) between sandstone and MKC coal bed. Tygart Valley River outcrop, WV. 


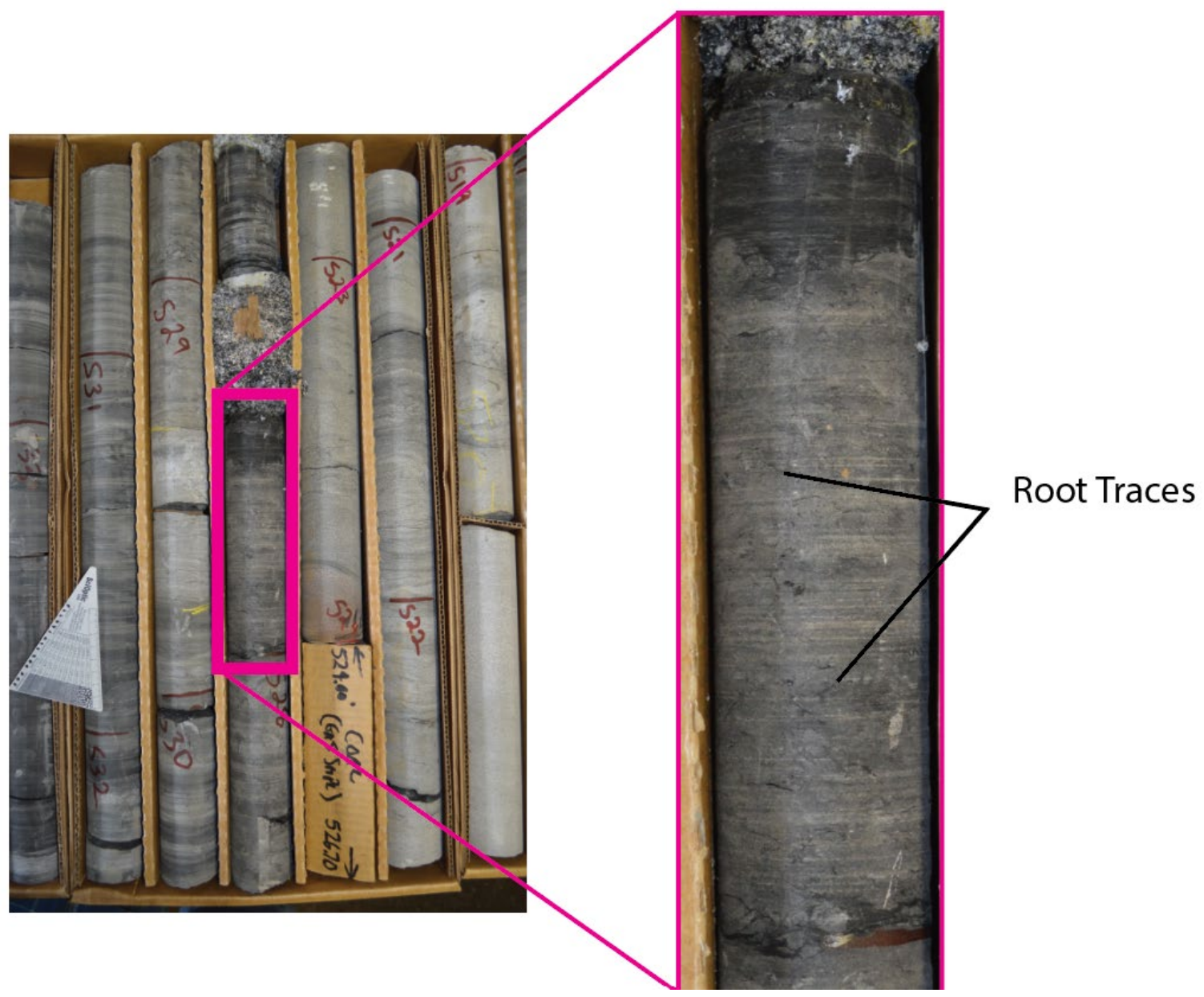

Figure 3-9: Example of paleosol in core data. Nestorville core-WVGES ID 302-072. 
Table 3-1: Defining Features for High Accommodation System Tracts (HAST) and Low Accommodation System Tracts (LAST) (Catuneanu, 2003; Neal and Abreu, 2009; Atkins, 2016) $\mathrm{A}=$ Accommodation, $\mathrm{S}=$ Sediment supply

\begin{tabular}{|l|l|l|}
\hline Features & LAST & HAST \\
\hline Accommodation succession & -A/S & + A/S \\
\hline Depositional Energy & Decline through time & Early increase, then decline \\
\hline Grading & Coarsening-upwards at base & Fining-upwards \\
\hline Grain Size & Coarser & Finer \\
\hline Sand : Mud & High & Low \\
\hline Channel fill Architecture & Amalgamated & Isolated \\
\hline Floodplain Facies & Sparse & Abundant \\
\hline Thickness & Thinner & Thicker \\
\hline Coal Availability & Fewer & Abundant \\
\hline Paleosols & Well developed & Poorly developed \\
\hline
\end{tabular}

\section{Results and Interpretation}

\subsection{Facies Association}

\subsubsection{Facies Association 1 - Channel Deposits}

Facies association 1 are channel deposits characterized by upward-fining trough-cross, planar cross, and ripple laminated sandstones and mudrock facies (Abatan et al., in prep). The sandstones are characterized by gray to light gray, poorly to well-sorted, planar or inclined, tabular or lenticular, fine to very coarse-grained, sandstone beds with near horizontal or curved, sharp and sometimes erosional bedding plane. The trough cross, planar and ripple laminated sandstone beds are interpreted as channel deposits (Abatan et al., in prep). The deposits may be channel thalweg or channel bar deposits. The mudrocks comprise massive or laminated, planar or lenticular, siltstone, mudstone, claystone and shale lamina and beds with sharp rarely 
erosional bedding plane or basal bounding surface. The shale may be locally carbonaceous. The mudrocks are interpreted as channel abandonment fill. The occurrence of curved bedding planes and lenticular geometry suggest bedload deposition on a curved surface which is common in channelized depositional environment (Abatan et al., in prep). Paleocurrent measurements ( $\mathrm{n}=$ 116) of the cross-bedded sandstone from the outcrop indicate southeast to northwest paleocurrent direction (Abatan et al., in prep).

\subsubsection{Facies Association 2 - Floodplain Deposits (Including crevasse splay, paleosol and mire deposits)}

Facies association 2 are floodplain deposits characterized by mudrock, coal, and ripple laminated sandstone facies (Abatan et al., in prep). The mudrock facies may be carbonaceous and contain rooting structures. Floodplain deposits have a coarsening upwards or fining upwards stacking pattern. The coal beds are mainly blocky and frequently contain siltstone, shale or mudstone partings. The ripple laminated sandstone beds are made up of moderately sorted, planar, fine-grained sandstones with a sharp, horizontal or curved basal surface.

The mudrocks are formed from suspended floodwater sediments that settle out of suspension. These mudrocks mainly have a fining upwards stacking pattern. Mudrocks with rooting structures are interpreted to have been sub-aerially exposed. The coal beds formed from peat mire deposits. The presence of mudrock partings in the coal beds indicates there was clastic sediment transport and minor, local base-level changes during peat deposition. The ripple laminated sandstone beds are interpreted as crevasse splay deposits. The crevasse splay deposits have coarsening upward beds with basal ripple laminated sandstones interpreted as forming in a relatively well-drained floodplain. The tabular nature of the deposits suggests they were deposited on a planar surface which is common in a floodplain depositional environment. The abundance of mudrock facies suggests a lower level of bedload sediment influx than channelized environments and the dominance of suspended load by the transporting medium.

\subsubsection{Facies Association 3 - Floodplain Delta and Lake Deposit}

Facies association 3 are lacustrine deposits characterized by lacustrine and delta facies. The lacustrine facies comprises of laterally extensive $(>100 \mathrm{~m})$ tabular, planar laminated and planar bedded, massive sandstone, and limestone deposits (Abatan et al., in prep). The delta facies are characterized by tabular or lenticular, planar cross, ripple, and horizontally laminated sandstone beds and interlaminated and interbedded mudstone, siltstone and sandstone with a coarsening upward stacking pattern. The cross-bedded sandstones dip in opposite directions.

The tabular geometry of limestone, sandstone, and mudrocks indicates they have been deposited on a planar surface which is common in the lacustrine depositional environment. The limestone is interpreted as lacustrine deposits due to the lack of marine fossils (Cecil, 1990; Cecil et al., 1993; Donaldson et al., 1985). The upper facies which comprise tabular ripple laminated, horizontal laminated and planar cross-bedded sandstone and interbedded siltstone and sandstone, are lacustrine delta front deposits (Abatan et al., in prep). The underlying interbedded mudstone and siltstone are the prodelta deposits. The deltaic deposits were interpreted as lacustrine deposits because they are associated with massive tabular lacustrine sandstone deposits. The 
coarsening upward stacking pattern is common in a deltaic depositional environment. The occurrence of cross-beds with bidirectional dip may be due to the back and forth movement of lake currents (Corbeanu et al., 2004). Overall, the MPAF deposits are characterized by upwardfining sandstone, which is common in fluvial depositional environments.

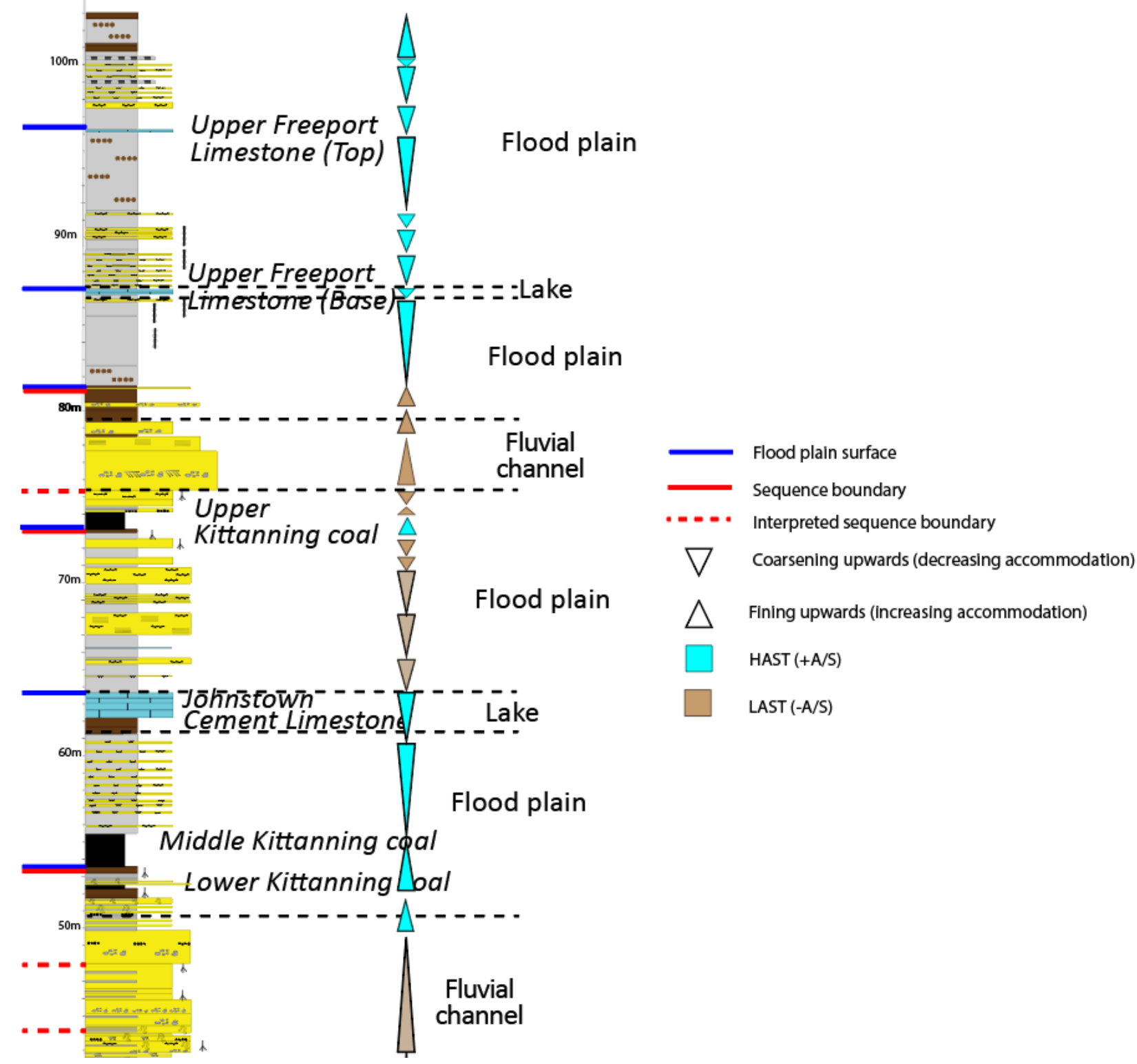

Figure 3-10: Example of floodplain surface, sequence boundary and accommodation succession in a lithologic section. Buckhannon core - 285-073, north-central, WV. 


\subsubsection{Sequences}

Five sequences and partial sequences have been identified in the upper MPAF. A complete sequence is characterized by one or more coupled LAST-HAST packages bounded above and below by SB, while a partial sequence is characterized by either one or more LAST or HAST. An example of a partial sequence is SB 1, which comprises a single HAST sediment package but is bounded above and below by SB (Fig. 3-11).

Sequence boundary surfaces originate from erosional bases of multistory channels, and these surfaces often merged at the subaerial unconformity at the top paleosols that underlie FS (Fig. 3-6 and Fig. 3-10). The FS were interpreted in each lithologic section and were partially correlated across the study area. FS were significantly less common in the channel deposits, which highlights the erosive nature and loss of floodplain fill in the fluvial valley (Bridge, 2009).

\subsubsection{Sequence 1}

Sequence 1 is associated with the Lower Kittanning coal bed (LKC) and comprises fine to medium-grained, channel sandstones and floodplain mudrocks with rooted paleosols (Fig. 311). The channel sandstone beds are characterized by inclined, trough cross-bedded sandstones in the more proximal part of the basin where they outcrop in Birch River and Tygart Valley. The more distal coeval deposits of the sequence 1 channel sandstones were not encountered in core or outcrop data. The absence of distal sequence 1 channel deposits in the data may be due to the data set originating from the floodplain section of the fluvial system. The channel sandstones of sequence 1 at Birch River and Tygart Valley outcrops are characterized by fine to mediumgrained, inclined or lens-shaped, planar and trough cross-bedded sandstones, with inclined, sharp bedding planes. The sandstone beds are bounded below by a sharp, undulating erosional surface interpreted as a sequence boundary (SB). The channel sandstone contained mud-drapes in most places and are generally overlain by carbonaceous shale interpreted as floodplain deposits. The contact between the floodplain deposit and the sandstone was interpreted as a floodplain surface (FS). The overlying mudrock deposit did not show evidence of pedogenesis. Additionally, the channel sandstone beds directly below the silt and shale deposits of the floodplain at both the Birch River and Tygart valley outcrop are contorted due to soft-sediment deformation and hand samples show they have quartz-rich grain composition ( $\sim 90 \%$ quartz abundance). The floodplain deposits at the Birch River outcrop are characterized by siltstone, carbonaceous shale and massive claystones, while the Tygart Valley outcrop lacked carbonaceous shale there was abundant siltstone. Core data is characterized by interbedded thin, fine-grained, ripple laminated sandstone beds within the floodplain mudrocks. The floodplain mudrocks are characterized by abundant shales and claystones, and fewer siltstones and sandstones. The claystones are rooted and contain abundant carbonized plant debris.

The deposits of Sequence 1 were interpreted as HAST packages due to the presence of mud-drapes in sandstones of the channel depositional environment and the abundance of mudrocks in the floodplain depositional environment, signaling $+\mathrm{A} / \mathrm{S}$ conditions in the fluvial depositional system (Fig. 3-8). The erosional base of the channel and the rooted claystone of the floodplain were interpreted as sequence boundaries (Cecil et al., 2003; Greb et al., 2008; Martino, 2004, 2016). The contact between channel sandstones and overlying floodplain 
mudrocks was interpreted as the floodplain surface. The capping of sequence 1 by coal beds indicates that base-level and accommodation continued to increase so that clastic input was minimal and coal-forming peat swamps thrived.

\subsubsection{Sequence 2}

Sequence 2 is associated with the Middle Kittanning coal bed (MKC). Deposits of sequence 2 deposits overlie and truncate sequence 1 and contain multistory, inclined, fine to coarse-grained channel sandstone, and mud-dominated to interlaminated mud and sand-rich floodplain deposits (Fig. 3-11). The channel deposits are bounded by a basal erosional surface which truncates the LKC. The channel sandstones are characterized by fine to coarse-grained, inclined, horizontally laminated, planar and trough cross-bedded sandstone with sharp, horizontal bedding plane in the proximal part of the basins in the east. At the Tygart Valley outcrop, the multistory channel sands are separated by mudrocks overlain by the lower split of the MKC coal bed. The lower channel story is characterized by fine- to medium-grained sandstone beds which are capped by mud-drapes. The basal sandstones of the lower channel story, which truncates and overlies the LKC, are amalgamated with increasing interbedded muddrapes upsection. The mud-draped sandstone beds are overlain by sandstones of the upper channel story where the lower split of the MKC is absent. The upper channel story, which is characterized by medium to coarse-grained, amalgamated sandstone beds, overlies and truncates sandstones of the lower channel story or the lower split of the Middle Kittanning coal bed. The upper story is overlain by interlaminated ripple laminated sandstone, siltstone, and shale which is overlain by the MKC. Core data from the distal part of the basin lack channel facies. The lack of channel facies in core data might be because channel formation was restricted/localized within the floodplain and was not encountered by cores. The floodplain deposits associated with Sequence 2 contain more silt and sandstone than the floodplain deposit associated with Sequence 1. Floodplain deposits in the distal part of the basin contain shale with abundant siderite clast in the stratigraphically lower section and rooted claystones in the upper section. The floodplain mudrocks are overlain by the $\mathrm{MKC}$, which in turn is overlain by up to $25 \mathrm{~m}$ thick section shale and interlaminated sandstone siltstone and shale towards the north and northeastern WV. The interlaminated sandstone, siltstone, and shale are overlain by claystone and limestone. The limestone is overlain by shale and up to $3 \mathrm{~m}$ thick, interbedded, very fine to fine ripple laminated sandstone and shale deposits. The interbedded, very fine to fine ripple laminated sandstone and shale deposits are overlain by rooted mudrock.

The deposits of sequence 2 contain both LAST and HAST packages (Fig. 3-10). The erosional base of the lower channel story and the $\mathrm{MKC}$ underclays of the floodplain were interpreted as SB (Cecil et al., 2003; Greb et al., 2008; Martino, 2004, 2016). The mudrock overlying the channel sandstones are interpreted as floodplain deposits and not abandonment plugs because of the lateral continuity of the mudrocks. The lower channel story with its muddraped sandstone and shale dominated floodplain deposits suggest deposition by a fluvial system with $+\mathrm{A} / \mathrm{S}$ and hence a high base level. Therefore, the lower channel story and associated floodplain deposits are interpreted as HAST packages. The upper channel story with its amalgamated sandstone beds and floodplain deposits characterized by rooted paleosols and interlaminated sandstone, siltstone, and shale, are indicative of deposits of a fluvial system with - 
$\mathrm{A} / \mathrm{S}$ and low base level. Therefore, the upper channel story and the upper floodplain deposits are interpreted as LAST packages. The contact between channel sandstones and overlying floodplain mudrocks, and the floodplain mudrocks and limestone were interpreted as the FS. The MKC, which overlies the mudrocks were deposited during the flooding stage. The lower MKC split was deposited during periods of autogenically driven accommodation changes in the fluvial depositional system which may have led to channel avulsion and the accumulation of channel sandstone between two MKC, hence they are observed locally at the Tygart Valley outcrop (Hajek and Straub, 2017; Sahoo and Gani, 2016). The main MKC was deposited during allogenically driven flooding of the basin, hence the MKC beds are widespread and appear in most of the study area. The shale and limestone overlying the MKC indicates an increase of base-level and sufficient clastic sediment influx to smother the peat swamps. The increased baselevel became high enough to facilitate a lacustrine carbonate depositional setting which resulted in the deposition of the Johnstown Limestone. The shale and interbedded ripple laminated sandstone and shale deposits overlying the Johnstown Limestone suggest increased clastic influx overwhelmed the carbonate factory. The overlying rooted mudrock suggests another sequence boundary developed above the floodplain deposits of sequence 2 .

\subsubsection{Sequence 3}

Sequence 3 is associated with the Upper Kittanning coal bed (UKC) and contains inclined, planar and trough cross-bedded channel sandstone along with floodplain deposits including mudrock, silt, and ripple laminated sandstone. The channel deposits comprise multistory, fine to coarse-grained channel sandstone that exhibit sharp, planar bedding planes. The multi-story sandstone complex is bounded by a basal erosional surface that overlies and truncates the underlying $\mathrm{MKC}$ and/or associated mudrock. The proximal medium to coarse-grained crossbedded multi-story channel sandstone complex at Tygart Valley contains abundant siderite and mud-drapes in the basal sandstone beds, which are absent upsection. The channel sandstones are overlain by floodplain deposits composed of shale and interlaminated siltstone and shale, limestone and calcareous mudrocks and sandstones (Fig. 2-10). Toward the west, away from the orogenic sediment source area, shale is more prevalent relative to siltstone in the floodplain. Floodplain deposits are overlain by the UKC, and in turn, the UKC is overlain shale, interlaminated siltstone and shale, and/ or ripple laminated sandstone, which is rooted in most places. The interlaminated siltstone and shale, and/or ripple laminated sandstone are overlain by claystone in some places.

The deposits of sequence 3 contains a single HAST-LAST package. The erosional base of the channel and the underclay of the floodplain were interpreted as SB/FB sequence boundaries (Cecil et al., 2003; Greb et al., 2008; Martino, 2004, 2016). The contact between channel sandstones and overlying floodplain mudrocks was interpreted as the floodplain surface (Falcon-Lang and Dimichele, 2010). The HAST package is characterized by sandstone beds with mud-drapes and abundant siderite intraclast and shale beds which dominated the floodplain. Siderite is an authigenic mineral formed in a humid, anoxic, diagenetic environment which requires a high groundwater table. The abundance of shale in the floodplain indicates a poorly drained, flooded fluvial depositional environment which is commonly associated with fluvial systems with $+\mathrm{A} / \mathrm{S}$. A $+\mathrm{A} / \mathrm{S}$ ratio indicates a high base-level in the early stage of sedimentation 
in sequence 3. The occurrence of LAST deposits which are characterized by ripple laminated sandstone beds and calcareous mudrocks in the floodplain and channel sandstone deposits without siderite intraclast and mud-draped sandstone beds signaled the onset of base-level fall in the fluvial depositional system. The ripple laminated sandstone is rooted in places, suggesting water levels were low enough to allow for plant colonization. The absence of siderite intraclast in the channel sandstone suggest reworked the floodplain deposits' lack of moisture after the sandstone was deposited (Allen et al., 2014), while the presence of calcareous mudrocks have been attributed to prolonged periods of standing water in a lacustrine setting under seasonal semi-arid climate and low clastic influx. The absence of mud-draped beds in the channel deposits indicate a low sand to mud ratio which is common in fluvial systems with $-\mathrm{A} / \mathrm{S}$ and hence low base level.

\subsubsection{Sequence 4}

Sequence 4 is made up of multistory, medium to very coarse-grained channel sandstones and floodplain deposits characterized by shale, interlaminated shale and ripple laminated sandstone and minor siltstone. Sequence 4 is associated with the Lower Freeport coal bed (LFC). The channel stories are separated by an erosional surface. The channel stories are bounded by a basal erosional surface that overlies and truncates the UKC. Data from Tygart Valley outcrop in the proximal part of the basin shows that the lower channel story is characterized by inclined, medium to coarse-grained, amalgamated, planar cross-bedded sandstone with sharp horizontal bedding plane. The upper story is characterized by massive, quartz pebble-grained sandstone beds. The sandstone beds are overlain by claystone in some places. The floodplain deposits may overlie the channel claystone or sandstone deposits. The floodplain deposits are characterized by shale, siltstone, and interlaminated shale and ripple laminated sandstone, and calcareous mudrocks. The floodplain in the proximal part of the basin is characterized by shale deposits which may be overlain by interlaminated shale and ripple laminated sandstone in some places. Where the interlaminated shale and ripple laminated sandstone is absent, the floodplain mudrock is characterized by calcareous siltstone, mudrock or claystone. The shale and interlaminated shale and ripple laminated sandstone may be capped by rooted claystone or shale. The upper mudrock of the floodplain deposits may be capped by the Lower Freeport coal bed in some places. The floodplain is dominated by shale and minor siltstone in the distal part of the basin. The Lower Freeport coal beds are absent in some of the core and outcrop data. The absence may be due to non-deposition, particularly within the channel belt, or erosion.

Sequence 4 has both LAST and HAST packages. The erosional base of the basal channel sandstone and the LFC underclay in the floodplain were interpreted as SB (Cecil et al., 2003; Greb et al., 2008; Martino, 2004, 2016). The channel sandstone and floodplain mudrock contact surface, as well as the limestone surface, were interpreted as FS (Cecil et al., 2003). The calcareous mudrocks and interlaminated mudrock and sandstone deposits are interpreted as LAST floodplain that was formed during prolonged dry, semi-arid conditions which led to a reduction in stratigraphic base-level of the fluvial system and hence $-\mathrm{A} / \mathrm{S}$. The multistory, amalgamated, very coarse-grained channel sandstone and floodplain deposits characterized by interlaminated shale and ripple laminated sandstone indicate -A/S and hence low base level, 
while the shale, mudstone and claystone deposits are interpreted as floodplain mudflat deposits indicate $\mathrm{a}+\mathrm{A} / \mathrm{S}$ and hence a high base-level (HAST).

\subsubsection{Sequence 5}

Sequence 5 is associated with the Upper Freeport coal bed and is characterized by channel deposits with up to $4 \mathrm{~mm}$ thick quartz pebble-bearing sandstone, and floodplain deposits characterized by claystones, shale, and the Upper Freeport Limestone. The channel sandstone overlies and truncates mudrocks of Sequence 4. The channel sandstone in the proximal part of the basin exposed at the Tygart Valley outcrop is massive due to its internally homogeneous nature. Floodplain deposits from core data are characterized by shale and claystone deposits which may be rooted and contain sandstone in some places and the Upper Freeport Limestone. The mudrocks are overlain by the Upper Freeport Limestone in places. The Upper Freeport Limestone is overlain by more shale beds and interlaminated shale and ripple laminated sandstone. The Upper Freeport Limestone is absent where channel sandstones are present (Fig. 3-11).

Sequence 5 contains comprises a LAST and HAST package. The massive pebbly sandstone and the floodplain deposits characterized by rooted claystone were interpreted as channel sandstone and paleosols respectively (Amorosi et al., 2017; Cecil et al., 2003; DiMichele, 2013). The mudrocks contain sandstones which suggests low water levels in the floodplain (LAST). Shale and limestone deposits are common in a poorly drained and flooded fluvial deposition environment. The limestone deposits that were formed as part of LAST when stratigraphic base-level in the fluvial systems were low, continued as stratigraphic base-level in the basin continued to increase. Continued increase in stratigraphic base-level resulted in the accumulation of HAST. The erosional base of the sandstone and the subaerial unconformity represented by the paleosol were interpreted as a SB-FS (Greb et al., 2008; Martino, 2004, 2016). It should be noted that most of the core and outcrop did not have the Upper Freeport coal bed associated with SB 5, however, quartz and shale pebbles which characterize the erosional channel base associated with SB 5 may have been caused by allogenic processes. 


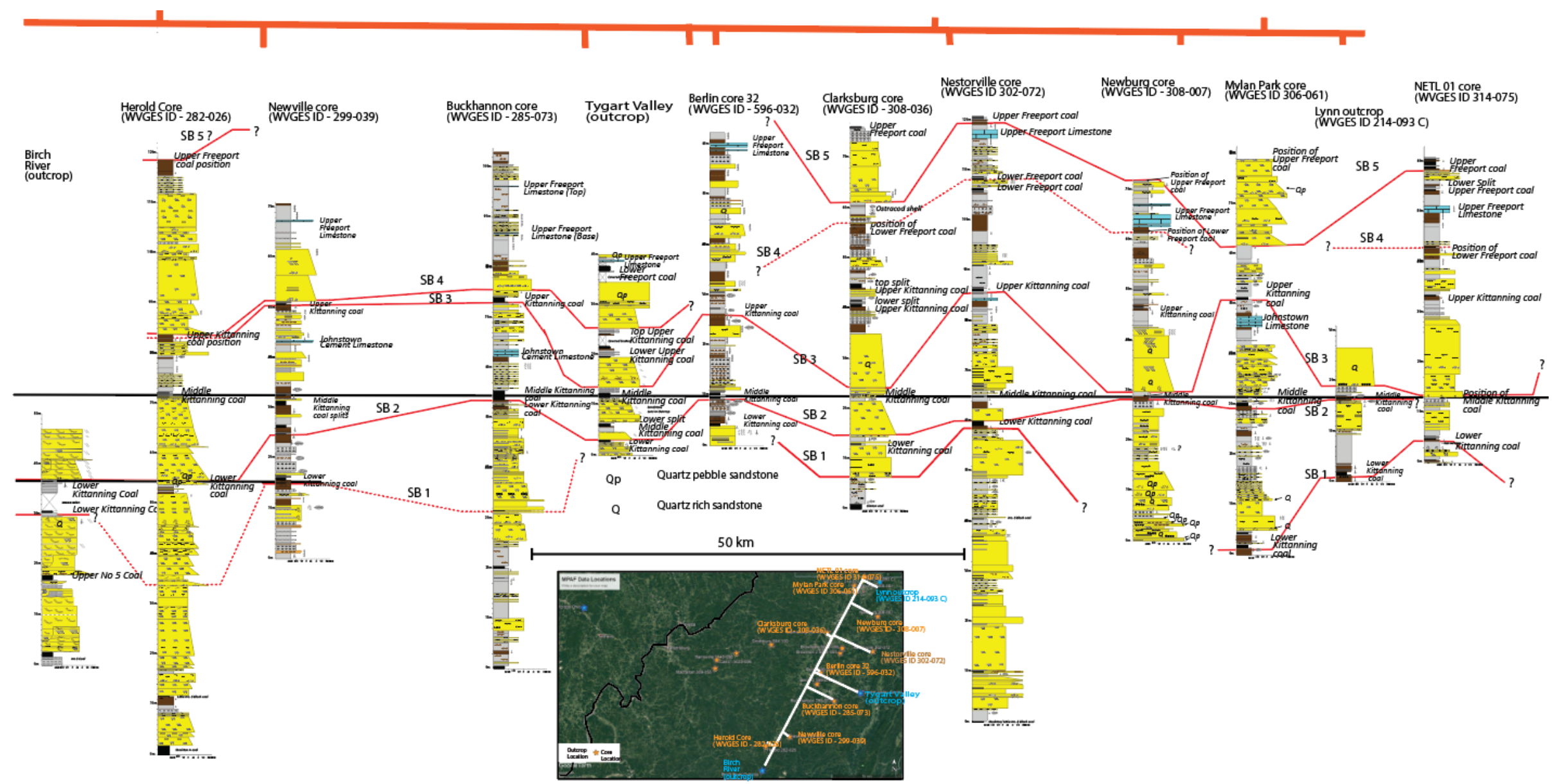

Figure 3-11: Sequence stratigraphic correlation of the MPAF. 


\begin{tabular}{|l|l|l|l|l|}
\hline Sequence & \multicolumn{1}{|c|}{ MPAF Coal beds } & System Tracts & Cyclothem* & $\begin{array}{l}\text { Accommodation Curve* } \\
\text { Increase Decrease }\end{array}$ \\
\hline 5 & Upper Freeport & HAST, LAST & Altamont & \\
\hline 4 & Lower Freeport & HAST, LAST & Pawnee & \\
\hline 3 & Upper Kittanning coal & LAST, HAST & Upr. Ft. Scott & \\
\hline 1 & Middle Kittanning coal & LAST, HAST & Lwr. Ft. Scott & \\
\hline
\end{tabular}

* - modified from Heckel, 2008.

Figure 3-12: Summary of sequences and depositional tracts of the upper MPAF 


\subsection{Controlling Mechanisms of Base-level Changes and Accommodation}

Mechanisms such as hydrology and sediment supply, which influence fluvial depositional systems and hence shape fluvial depositional architecture, are controlled by eustatic, tectonic and climatic processes. The proximal part of the study area, which includes the Birch River and Tygart Valley outcrops, have been interpreted as terrestrial fluvial system due to the absence of marine fossils or lithologic indicators of marine environment, which implies base-level and accommodation changes were controlled by tectonic and paleoclimate processes. Though, the accumulation of deposits in the proximal, central, part of the basin was attributed to a greater rate of subsidence (Ettensohn, 2008), paleoslope estimates of MPAF channel deposits suggest the MPAF depositional environment was deposited in an flat physiographic terrain with low slope values (0.00007 - 0.0004) comparable to slope ranges for the Amazon, Mississippi and Niger Rivers (Abatan and Weislogel, 2019). The only evidence of tectonic activity observed in the MPAF are in the water escape features associated with the deformed channel sandstone beds deposited below the Lower Kittanning coal bed, which may have been activated by seismic activities associated with tectonism (Figure 3-3 and Fig. 3-4 and Chapter 1, Abatan et al. in progress). However, the presence of root structures in the deformed sandstone indicates they are deposits of seasonally wet-dry environments common in fluvial systems of semi-arid/ semihumid regions with higher evapotranspiration than precipitation rates (Cecil, 1990; DiMichele et al., 2010; Fielding et al., 2009). This may also be the case for the presence of calcrete and caliche in mudrocks associated with limestone deposits of the upper part of the MPAF (Cecil, 1990; DiMichele et al., 2010; Martino, 2016). A high base-level, controlled by eustatic transgression and regression, facilitates accommodation that allowed for channel sands and floodplain mudrock, peat and limestone deposition.

The five sequences correlate with previously interpreted cyclothem stages, which indicates accommodation was being controlled by eustasy (Fig. 3-12; Falcon-Lang et al., 2011; Heckel, 2008; Montañez et al., 2016). Heckle (2008) developed an accommodation curve by comparing midcontinent, Illinois and Appalachian basin cyclothems. This accommodation curve agrees with the frequency of the distribution of shale (high accommodation) and sandstone (low accommodation) observed in the study area (Fig. 3-12). While it is possible that the distribution of lithology is representative of the allogenic controls on accommodation of the Appalachian basin's fluvial environments, more data and further sands to shale ratio analysis will be required to support that conclusion. However, some lithologies such as calcrete and caliche in mudrock underclay suggest deposition in a seasonally wet-dry environment. Other studies suggested that the local compaction of mire deposits (mainly peat), by overlying deposits results in the creation of more accommodation locally and hence the preservation of thicker deposits in such areas (Wilkinson et al., 2003; Sahoo and Gani, 2016). Analysis of the thickness of deposits above coal beds from the decompaction process appear to be random. Though the randomness may be due creation of accommodation by compacted mire deposit, the overall thickness of deposits, including those not above mire deposits, suggests that accommodation in the proximal part of the basin was widespread and may be controlled by tectonic subsidence. High-frequency $(\sim 10,000-$ 
100,000 yrs) base-level changes within the foreland basin has been attributed to changes in precipitation rates brought about by paleoclimate change (Cecil, 1990; Cecil et al., 2003). The occurrence of deformed beddings, which suggest a high groundwater table, indicates periods of high base-level and rooting structure in the sandstone below the LKC (See Birch River lithologic section, Fig. 3-4), indicates low base level. Such high-frequency change in base-level has been attributed to hydrologic processes in a highly seasonal depositional environment.

\section{Conclusion}

This study advanced a sequence stratigraphic framework from which genetically related surfaces of floodplain paleosols and erosional bases of a fluvial depositional system were identified and correlated across the basin. This resulted in the correlation of genetically related tops of paleosols and erosional channel bases in three outcrops and fifteen core locations across the Middle Pennsylvanian Allegheny Formation (MPAF) fluvial depositional system. The resulting sequences showed variation in fluvial stacking patterns which were driven by accommodation changes.

The MPAF sequences are categorized into high accommodation sequence tracts, which are characterized by coal, limestone, and mudrock dominated floodplain deposits, and channel sandstones deposits with high mudrock content compared to sandstone; and low accommodation sequence tracts characterized by floodplain deposits with a high sand content and channel fills that lack mudrocks and may incise into finer-grained channel deposits.

Five sequences were identified by correlating interpreted sequence boundaries (SB) across erosive channel bases and subaerial unconformities above paleosols of adjacent floodplain sections. Accommodation succession interpreted from the integration of facies architectural analysis and key bounding surface in both floodplain and channel deposits showed that the sequence 1-3 were deposited by fluvial systems with low base-level and lower accommodation, while sequence 4 and 5 were deposited by fluvial systems with high base-level and high accommodation. A comparison of the facies architecture and sequence stratigraphic units of the MPAF revealed that accommodation may have been driven by tectonic subsidence or eustatic base-level changes. These sequences agree with Pennsylvanian cyclothem grouping from previous studies. Sedimentary fill was influenced by wet to seasonally wet-dry climatic changes.

This study was able to propose a sequence stratigraphic framework for fluvial depositional systems which can be compared with previously established accommodation driven Pennsylvanian cyclothems. Though data points for this study were far apart, the sequence stratigraphic framework developed may be applied to additional data to improve the resolution of the distribution of stratigraphic units across the Appalachian Basin. 


\section{$8 \quad$ References}

Abatan, O., Weislogel, A., Blake Jr, B.M., in prep. Process Based Analysis of Fluvial Stratigraphic Record: The Middle Pennsylvanina Allegheny Formation, WV.

Allen, J.P., Fielding, C.R., Gibling, M.R., Rygel, M.C., 2014. Recognizing products of palaeoclimate fluctuation in the fluvial stratigraphic record: An example from the Pennsylvanian to Lower Permian of Cape Breton Island, Nova Scotia. Sedimentology 61, 1332-1381.

Allen, J.P., Fielding, C.R., Gibling, M.R., Rygel, M.C., 2011. Fluvial response to paleoequatorial climate fluctuations during the late Paleozoic ice age. Geological Society of America Bulletin 123, 1524-1538.

Amorosi, A., Bruno, L., Cleveland, D.M., Morelli, A., Hong, W., 2017. Paleosols and associated channel-belt sand bodies from a continuously subsiding late Quaternary system (Po Basin, Italy): New insights into continental sequence stratigraphy. GSA Bulletin 129, 449-463. https://doi.org/10.1130/B31575.1

Atkins, S., 2016. Fluvial-deltaic deposition in high accommodation floodplain lakes, Pennsylvanian Appalachian Basin, eastern Kentucky [electronic resource]. UMI thesis.

Bailey, A., 1981. Chemical and mineralogical differences between Kittanning coals from marine-influenced versus fluvial sequences. Journal of Sedimentary Research 51, 383395.

Belt, E.S., Heckel, P.H., Lentz, L.J., Bragonier, W.A., Lyons, T.W., 2011. Record of glacialeustatic sea-level fluctuations in complex middle to late Pennsylvanian facies in the Northern Appalachian Basin and relation to similar events in the Midcontinent basin. Sedimentary Geology 238, 79-100. https://doi.org/10.1016/j.sedgeo.2011.04.004

Belt, E.S., Lyons, P.C., 1989. A thrust-ridge paleodepositional model for the Upper Freeport coal bed and associated clastic facies, Upper Potomac coal field, Appalachian basin, USA. International journal of coal geology 12, 293-328.

Bhattacharya, J.P., 2011. Practical problems in the application of the sequence stratigraphic method and key surfaces: integrating observations from ancient fluvial-deltaic wedges with Quaternary and modelling studies. Sedimentology 58, 120-169.

Blake, B.M., and Beuthin, J.D., 2008. Deciphering the mid-Carboniferous eustatic event in the central Appalachian foreland basin, southern West Virginia, USA. Resolving the Late Paleozoic Ice Age in Time and Space: Geological Society of America Special Paper 441, 249-260.

Blum, M., Martin, J., Milliken, K., Garvin, M., 2013. Paleovalley systems: Insights from Quaternary analogs and experiments. Earth-Science Reviews 116, 128-169. https://doi.org/10.1016/j.earscirev.2012.09.003 
Blum, M.D., Törnqvist, T.E., 2000. Fluvial responses to climate and sea-level change: a review and look forward. Sedimentology 47, 2-48.

Bridge, J.S., 2009. Rivers and floodplains: forms, processes, and sedimentary record. John Wiley \& Sons.

Bridge, J.S., Leeder, M.R., 1979. A simulation model of alluvial stratigraphy. Sedimentology 26, 617-644.

Catuneanu, O., 2006. Principles of sequence stratigraphy. Elsevier, Amsterdam; Boston.

Catuneanu, O., 2003. Sequence stratigraphy of clastic systems. Geological Association of Canada St. John's Newfoundland.

Catuneanu, O., Khalifa, M.A., Wanas, H.A., 2006. Sequence stratigraphy and incised-valley systems of the Cenomanian Bahariya Formation, Western Desert, Egypt. Sediment Geol 190, 121-137.

Cecil, C.B., 1990. Paleoclimate controls on stratigraphic repetition of chemical and siliciclastic rocks. Geology 18, 533-536.

Cecil, C.B., Brezinski, D.K., Dulong, F., 2004. The Paleozoic record of changes in global climate and sea level: Central Appalachian Basin. Geology of the National Capital Region-Field Trip Guidebook: US Geological Survey Circular 1264, 77-133.

Cecil, C.B., Dulong, F.T., 2003. Precipitation Models for Sediment Supply in Warm Climates, in: Cecil, C.B., Edgar, N.T. (Eds.), Climate Controls on Stratigraphy. SEPM Society for Sedimentary Geology, p. 0. https://doi.org/10.2110/pec.03.77.0021

Cecil, C.B., Dulong, F.T., Cobb, J.C., Supardi, X.X., 1993. Allogenic and autogenic controls on sedimentation in the Central Sumatra Basin as an analogue for Pennsylvanian coalbearing strata in the Appalachian Basin. SPECIAL PAPERS-GEOLOGICAL SOCIETY OF AMERICA 3-3.

Cecil, C.B., Dulong, F.T., West, R.R., Stamm, R., Wardlaw, B., Edgar, N.T., 2003. Climate controls on the stratigraphy of a Middle Pennsylvanian cyclothem in North America, in: Cecil, C.B., Edgar, N.T. (Eds.), Climate Controls on Stratigraphy. SEPM Society for Sedimentary Geology, p. 0. https://doi.org/10.2110/pec.03.77.0151

Cecil, C.B., Englund, K.J., 1989. Origin of coal deposits and associated rocks in the Carboniferous of the Appalachian basin. Carboniferous Geology of the Eastern United States 84-104.

Chesnut Jr, D.R., 1994. Eustatic and tectonic control of deposition of the Lower and Middle Pennsylvanian strata of the central Appalachian Basin. SEPM, Tectonic and Eustatic Controls on Sedimentary Cycles 4, 51-64.

Corbeanu, R.M., Wizevich, M.C., Bhattacharya, J.P., Zeng, X., McMechan, G.A., 2004. Threedimensional architecture of ancient lower delta-plain point bars using ground-penetrating 
radar, Cretaceous Ferron Sandstone, Utah. Regional to Wellbore Analog for FluvialDeltaic Reservoir Modeling, The Ferron of Utah: American Association of Petroleum Geologists, Studies in Geology 50, 427-449.

Currie, B.S., 1997. Sequence stratigraphy of nonmarine Jurassic-Cretaceous rocks, central Cordilleran foreland-basin system. GSA Bulletin 109, 1206-1222. https://doi.org/10.1130/0016-7606(1997)109<1206:SSONJC>2.3.CO;2

DiMichele, W.A., 2013. Wetland-dryland vegetational dynamics in the Pennsylvanian ice age tropics. International Journal of Plant Sciences 175, 123-164.

DiMichele, W.A., Cecil, C.B., Montañez, I.P., Falcon-Lang, H.J., 2010. Cyclic changes in Pennsylvanian paleoclimate and effects on floristic dynamics in tropical Pangaea. International Journal of Coal Geology 83, 329-344.

Donaldson, A.C., Renton, J.J., Presley, M.W., 1985. Pennsylvanian deposystems and paleoclimates of the Appalachians. International Journal of Coal Geology 5, 167-193.

Donaldson, A.C., Shumaker, R.C., 1981. Late Paleozoic molasse of central Appalachians. Sedimentation and tectonics in alluvial basins: Geological Association of Canada Special Paper 23, 99-124.

Eble, C.F., 2002. Palynology of late Middle Pennsylvanian coal beds in the Appalachian Basin. International Journal of Coal Geology 50, 73-88.

Ettensohn, F.R., 2008. Chapter 4 The Appalachian Foreland Basin in Eastern United States, in: Miall, A.D. (Ed.), Sedimentary Basins of the World, The Sedimentary Basins of the United States and Canada. Elsevier, pp. 105-179.

Ettensohn, F.R., 2005. 5. The sedimentary record of foreland-basin, tectophase cycles: Examples from the Appalachian Basin, USA, in: Mabessoone, J.M., Neumann, V.H. (Eds.), Developments in Sedimentology, Cyclic Development of Sedimentary Basins. Elsevier, pp. 139-172. https://doi.org/10.1016/S0070-4571(05)80007-X

Ettensohn, F.R., 2004. Modeling the nature and development of major paleozoic clastic wedges in the Appalachian Basin, USA. Journal of Geodynamics, Tectonics of the Appalachian Belt 37, 657-681. https://doi.org/10.1016/j.jog.2004.02.009

Falcon-Lang, H.J., Dimichele, W.A., 2010. What happened to the coal forests during Pennsylvanian glacial phases? Palaios 25, 611-617.

Ferm, J.C., 1970. Allegheny deltaic deposits.

Ferm, J.C., Weisenfluh, G.A., 1989. Evolution of some depositional models in Late Carboniferous rocks of the Appalachian coal fields. International Journal of Coal Geology 12, 259-292.

Fielding, C.R., 1986. The anatomy of a coal seam split, Durham coalfield, Northeast England. Geological Journal 21, 45-57. 
Fielding, C.R., Allen, J.P., Alexander, J., Gibling, M.R., 2009. Facies model for fluvial systems in the seasonal tropics and subtropics. Geology 37, 623-626.

Greb, S.F., Pashin, J.C., Martino, R.L., Eble, C.F., 2008. Appalachian sedimentary cycles during the Pennsylvanian: Changing influences of sea level, climate, and tectonics. Geological Society of America Special Papers 441, 235-248. https://doi.org/10.1130/2008.2441(16)

Hajek, E.A., Straub, K.M., 2017. Autogenic sedimentation in clastic stratigraphy. Annual Review of Earth and Planetary Sciences 45, 681-709.

Heckel, P.H., 2008. Pennsylvanian cyclothems in Midcontinent North America as far-field effects of waxing and waning of Gondwana ice sheets. Resolving the Late Paleozoic Ice Age in Time and Space; Fielding, CR, Frank, TD, Isbell, JL, Eds 275-290.

Holbrook, J., Schumm, S.A., 1999. Geomorphic and sedimentary response of rivers to tectonic deformation: a brief review and critique of a tool for recognizing subtle epeirogenic deformation in modern and ancient settings. Tectonophysics 305, 287-306.

Holbrook, J., Scott, R.W., Oboh-Ikuenobe, F.E., 2006. Base-level buffers and buttresses: a model for upstream versus downstream control on fluvial geometry and architecture within sequences. Journal of Sedimentary Research 76, 162-174.

Holbrook, J.M., Bhattacharya, J.P., 2012. Reappraisal of the sequence boundary in time and space: case and considerations for an SU (subaerial unconformity) that is not a sediment bypass surface, a time barrier, or an unconformity. Earth-Science Reviews 113, 271-302.

Kraus, M.J., 1999. Paleosols in clastic sedimentary rocks: their geologic applications. EarthScience Reviews 47, 41-70.

Lin, W., Bhattacharya, J.P., Stockford, A., 2019. High-resolution Sequence Stratigraphy and Implications For Cretaceous Glacioeustasy of the Late Cretaceous Gallup System, New Mexico, U.S.A. Journal of Sedimentary Research 89, 552-575. https://doi.org/10.2110/jsr.2019.32

Martino, R., 2004. Sequence Stratigraphy of the Glenshaw Formation (Middle-Late Pennsylvanian) in the Central Appalachian Basin.

Martino, R.L., 2016. Sequence stratigraphy of fluvially-dominated strata of the Mid-Late Pennsylvanian Conemaugh Formation, Central Appalachian Basin. International Journal of Coal Geology 154-155, 136-154. https://doi.org/10.1016/j.coal.2015.12.016

Martino, R.L., 1996. Stratigraphy and depositional environments of the Kanawha Formation (Middle Pennsylvanian), southern West Virginia, USA. International Journal of Coal Geology 31, 217-248.

Miall, A., 2014. Fluvial Depositional Systems. Springer International Publishing, Cham. https://doi.org/10.1007/978-3-319-00666-6

Miall, A.D., 1996. The geology of fluvial deposits. Springer. 
Miall, A.D., Blakey, R.C., 2008. Chapter 1 The Phanerozoic Tectonic and Sedimentary Evolution of North America, in: Miall, A.D. (Ed.), Sedimentary Basins of the World, The Sedimentary Basins of the United States and Canada. Elsevier, pp. 1-29.

Mitchum, R., Vail, P., Sangree, J., 1977. Seismic stratigraphy and global changes of sea level, part 7: seismic stratigraphic interpretation procedure. Seismic Stratigraphy: Application to Hydrocarbon Exploration. AAPG Memoir 26, 135-143.

Neal, J., Abreu, V., 2009. Sequence stratigraphy hierarchy and the accommodation succession method. Geology 37, 779-782. https://doi.org/10.1130/G25722A.1

Pechacek, A.E., 2018. Sequence Stratigraphy of Middle to Upper Pennsylvanian Fill of the Central Appalachian Basin.

Sahoo, H., Gani, M.R., 2016. Autogenic Modulation of Fluvial Channel Fills In Allogenically Formed Incised Valleys: Cretaceous Blackhawk Formation, USA. SEPM (Society for Sedimentary Geology) No. 106. http://dx.doi.org/10.2110/sepmsp.106.08

Salvador, A., 1994. International stratigraphic guide: a guide to stratigraphic classification, terminology, and procedure. Geological Society of America.

Shanley, K.W., McCabe, P.J., 1994. Perspectives on the sequence stratigraphy of continental strata. AAPG bulletin 78, 544-568.

Strong, N., Paola, C., 2008. Valleys That Never Were: Time Surfaces Versus Stratigraphic Surfaces. Journal of Sedimentary Research 78, 579-593. https://doi.org/10.2110/jsr.2008.059

Stubbs, D.G., 2018. A Sequence Stratigraphic Analysis of the Allegheny Group (Middle Pennsylvanian), Southeast Ohio (Masters Thesis). Ohio University.

Tabor, N.J., Poulsen, C.J., 2008. Palaeoclimate across the Late Pennsylvanian-Early Permian tropical palaeolatitudes: a review of climate indicators, their distribution, and relation to palaeophysiographic climate factors. Palaeogeography, Palaeoclimatology, Palaeoecology 268, 293-310.

Tankard, A.J., 1986. On the depositional response to thrusting and lithospheric flexure: examples from the Appalachian and Rocky Mountain basins. Foreland basins 369-392.

Van Wagoner, J.C., Posamentier, H.W., Mitchum, R.M.J., Vail, P.R., Sarg, J.F., Loutit, T.S., Hardenbol, J., 1988. An overview of the fundamentals of sequence stratigraphy and key definitions.

Wadsworth, J., Boyd, R., Diessel, C., Leckie, D., 2003. Stratigraphic style of coal and nonmarine strata in a high accommodation setting: Falher Member and Gates Formation (Lower Cretaceous), western Canada. Bulletin of Canadian Petroleum Geology 51, 275303. 
Wagoner, J.C.V., Mitchum, R.M., Jr, Posamentier, H.W., Vail, P.R., 1987. Seismic Stratigraphy Interpretation Using Sequence Stratigraphy: Part 2: Key Definitions of Sequence Stratigraphy 11-14.

Wanless, H.R., Shepard, F.P., 1936. Sea level and climatic changes related to late Paleozoic cycles. Bulletin of the Geological Society of America 47, 1177-1206.

Wheeler, H.E., 1964. Baselevel, lithosphere surface, and time-stratigraphy. Geological Society of America Bulletin 75, 599-610.

Wheeler, H.E., Mallory, V.S., 1956. Factors in lithostratigraphy. AAPG Bulletin 40, 2711-2723.

Wilkinson, B.H., Diedrich, N.W., Drummond, C.N., Rothman, E.D., 1998. Michigan hockey, meteoric precipitation, and rhythmicity of accumulation on peritidal carbonate platforms. Geological Society of America Bulletin 110, 1075-1093.

Wright, V.P., Marriott, S.B., 1993. The sequence stratigraphy of fluvial depositional systems: the role of floodplain sediment storage. Sedimentary geology 86, 203-210. 